\title{
\#USGS
}

science for a changing world

Prepared in cooperation with the New England Interstate Water Pollution Control Commission

\section{Assessment of Total Nitrogen in the Upper Connecticut River Basin in New Hampshire, Vermont, and Massachusetts, December 2002-September 2005}

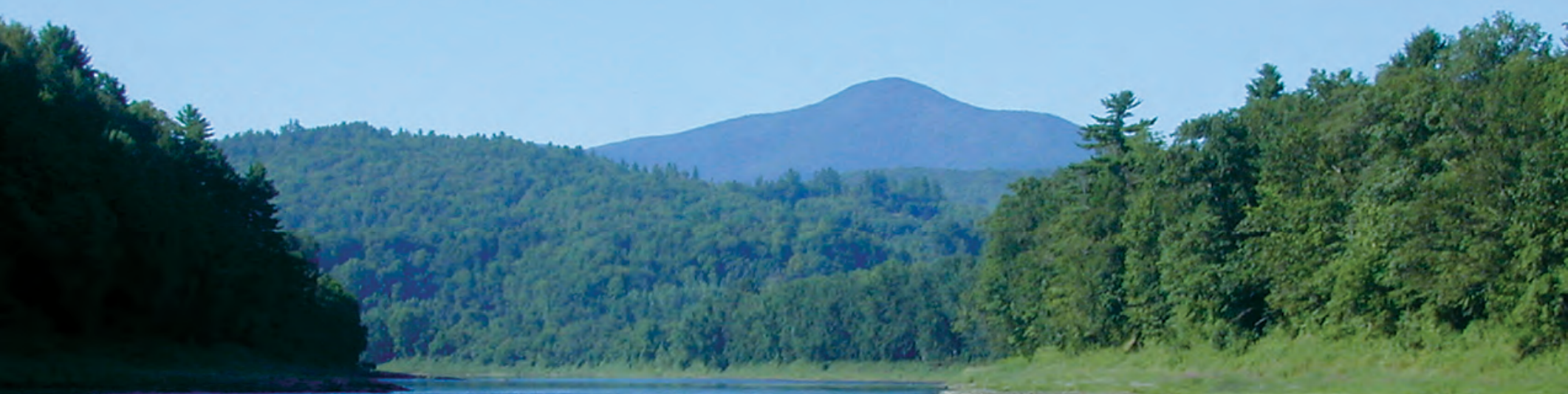

Scientific Investigations Report 2006-5144

U.S. Department of the Interior

U.S. Geological Survey 
Cover. Photograph shows the Connecticut River and Mt. Ascutney, Vermont, in the background. 


\section{Assessment of Total Nitrogen in the Upper Connecticut River Basin in New Hampshire, Vermont, and Massachusetts, December 2002-September 2005}

By Jeffrey R. Deacon, Thor E. Smith, Craig M. Johnston, Richard B. Moore,

Rebecca M. Weidman, and Laura J. Blake

Prepared in cooperation with the

New England Interstate Water Pollution Control Commission

Scientific Investigations Report 2006-5144 


\section{U.S. Department of the Interior DIRK KEMPTHORNE, Secretary \\ U.S. Geological Survey \\ P. Patrick Leahy, Acting Director}

\section{U.S. Geological Survey, Reston, Virginia: 2006}

For product and ordering information:

World Wide Web: http://www.usgs.gov/pubprod

Telephone: 1-888-ASK-USGS

For more information on the USGS--the Federal source for science about the Earth, its natural and living resources, natural hazards, and the environment:

World Wide Web: http://www.usgs.gov

Telephone: 1-888-ASK-USGS

Any use of trade, product, or firm names is for descriptive purposes only and does not imply endorsement by the U.S. Government.

Although this report is in the public domain, permission must be secured from the individual copyright owners to reproduce any copyrighted materials contained within this report.

Suggested citation:

Deacon, J.R., Smith, T.E., Johnston, C.M., Moore, R.B., Weidman, R.M., and Blake, L.J., 2006, Assessment of total nitrogen in the Upper Connecticut River Basin in New Hampshire, Vermont, and Massachusetts, December 2002September 2005: U.S. Geological Survey Scientific Investigations Report 2006-5144, 89 p. 


\section{Acknowledgments}

The authors acknowledge and appreciate the efforts of their U.S. Geological Survey colleagues provided by Ann Chalmers, Kimberly Campo, Domenic Murino, Joseph Martin, Jason Pollender, Tim Sargent, and Guy Holzer for their assistance in the collection of water-quality samples, and Sarah Flanagan, U.S. Geological Survey, for the formation of computer files for load estimation. Appreciation also is extended to the Connecticut Water Science Center for the collection and use of data from the Connecticut River at Thompsonville, CT. Thanks are extended to Norman Spahr and John Mullaney, U.S. Geological Survey, for their critical review of this report. Appreciation is extended to Kay E. Hedrick for the editorial report review, Ann Marie Squillacci for manuscript and layout, and Tina Cotton for graphics. 



\section{Contents}

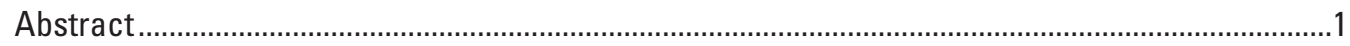

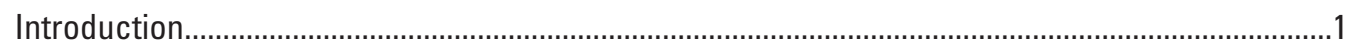

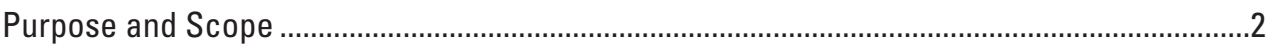

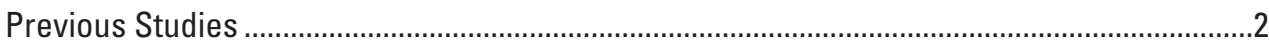

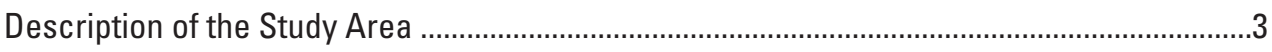

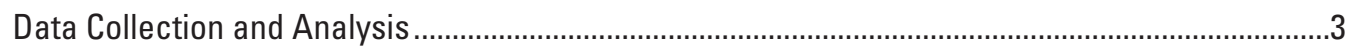

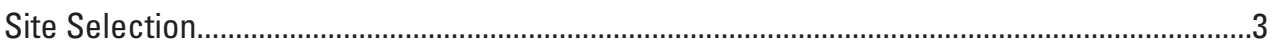

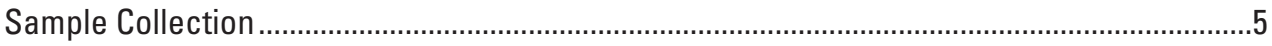

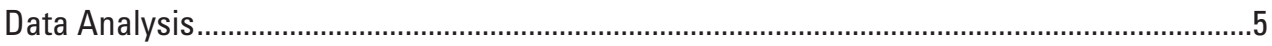

Characterization of Total Nitrogen at River Sampling Sites ............................................................

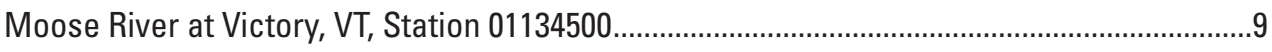

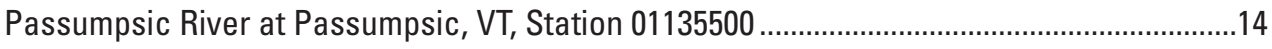

Connecticut River at Wells River, VT, Station 01138500 ......................................................19

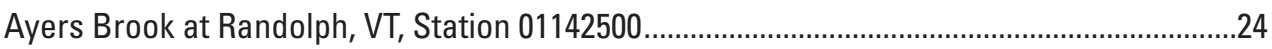

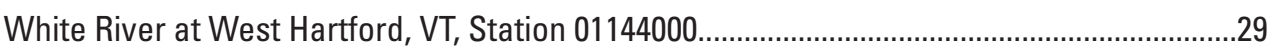

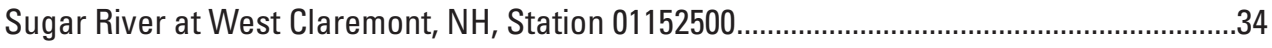

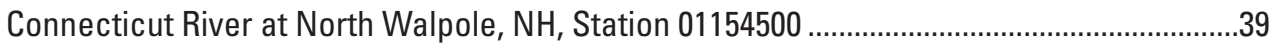

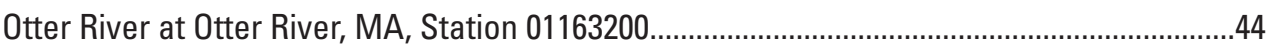

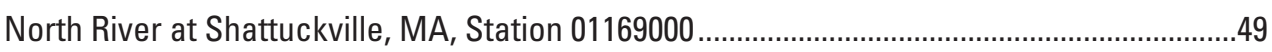

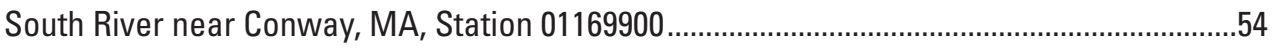

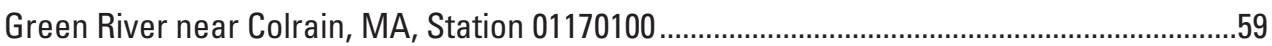

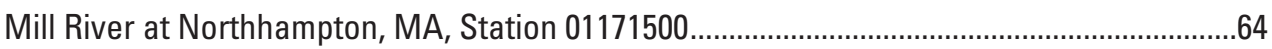

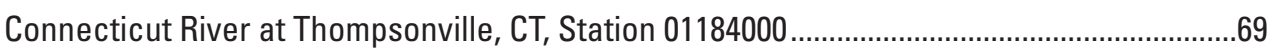

Characterization of Total Nitrogen at Wastewater-Treatment Sampling Sites ................................74

Comparison of Total Nitrogen Concentrations and Yields Among Site Types ....................................76

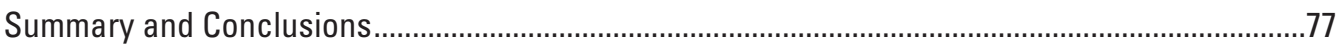

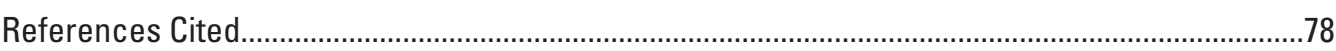

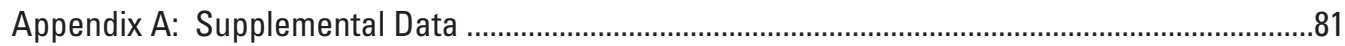

A-1. Annual loads, yields, and confidence intervals for total nitrogen and total phosphorus for river sampling sites in the upper Connecticut River Basin in New Hampshire, Vermont, and Massachusetts .......................................................82

A-2. Estimates of seasonal total nitrogen load for river sampling sites in the upper Connecticut River Basin in New Hampshire, Vermont, and Massachusetts..............85

A-3. Estimates of seasonal total phosphorus load for river sampling sites in the upper Connecticut River Basin in New Hampshire, Vermont, and Massachusetts...............87

A-4. Regression equations for estimates of total nitrogen load and total phosphorus load for river sampling sites in the upper Connecticut River Basin in New Hampshire, Vermont, and Massachusetts. 


\section{Figures}

1-2. Maps showing -

1. Sampling sites and site-identification numbers in the upper Connecticut River Basin in New Hampshire, Vermont, and Massachusetts

2. Location, land-use classification, and photograph of sampling site for Moose River at Victory, VT, station 01134500

3-5. Graphs showing-

3. A, Historical and study-period annual streamflow, and $B$, Daily mean streamflow and time distribution of water-quality samples for Moose River at Victory, VT, station 01134500

4. Distribution of $A$, Dissolved nitrite plus nitrate, $B$, Total ammonia plus organic nitrogen, $C$, Total nitrogen, $D$, Total phosphorus concentrations relative to streamflow, and $E$, Instantaneous total nitrogen load relative to time for Moose River at Victory, VT, station 01134500.

5. A, Total nitrogen load, by year, and $B$, Mean annual total nitrogen yield (2003-05) for Moose River near Victory, VT, station 01134500, in relation to all other river sampling sites.

6. Map showing location, land-use classification, and photograph of sampling site for Passumpsic River at Passumpsic, VT, station 01135500.

7-9. Graphs showing-

7. A, Historical and study-period annual streamflow, and $B$, Daily mean streamflow and time distribution of water-quality samples for Passumpsic River at Passumpsic, VT, station 01135500

8. Distribution of $A$, Dissolved nitrite plus nitrate, $B$, Total ammonia plus organic nitrogen, $C$, Total nitrogen, $D$, Total phosphorus concentrations relative to streamflow, and $E$, Instantaneous total nitrogen load relative to time for Passumpsic River at Passumpsic, VT, station 01135500.

9. $A$, Total nitrogen load, by year, and $B$, Mean annual total nitrogen yield (2003-05) for Passumpsic River at Passumpsic, VT, station 01135500, in relation to all other river sampling sites

10. Map showing location, land-use classification, and photograph of sampling site

for Connecticut River at Wells River, VT, station 01138500

11-13. Graphs showing-

11. A, Historical and study-period annual streamflow, and $B$, Daily mean streamflow and time distribution of water-quality samples for Connecticut River at Wells River, VT, station 01138500

12. Distribution of $A$, Dissolved nitrite plus nitrate, $B$, Total ammonia plus organic nitrogen, $C$, Total nitrogen, $D$, Total phosphorus concentrations relative to streamflow, and $E$, Instantaneous total nitrogen load relative to time for Connecticut River at Wells River, VT, station 01138500

13. $A$, Total nitrogen load, by year, and $B$, Mean annual total nitrogen yield (2003-05) for Connecticut River at Wells River, VT, station 01138500, in relation to all other river sampling sites

14. Map showing location, land-use classification, and photograph of sampling site for Ayers Brook at Randolph, VT, station 01142500. 
15-17. Graphs showing-

15. A, Historical and study-period annual streamflow, and $B$, Daily mean streamflow and time distribution of water-quality samples for Ayers Brook at Randolph, VT, station 01142500

16. Distribution of $A$, Dissolved nitrite plus nitrate, $B$, Total ammonia plus organic nitrogen, $C$, Total nitrogen, $D$, Total phosphorus concentrations relative to streamflow, and $E$, Instantaneous total nitrogen load relative to time for Ayers Brook at Randolph, VT, station 01142500

17. $A$, Total nitrogen load, by year, and $B$, Mean annual total nitrogen yield (2003-05) for Ayers Brook at Randolph, VT, station 01142500, in relation to all other river sampling sites.

18. Map showing location, land-use classification, and photograph of sampling site for White River at West Hartford, VT, station 01144000

19-21. Graphs showing-

19. A, Historical and study-period annual streamflow, and $B$, Daily mean streamflow and time distribution of water-quality samples for White River at West Hartford, VT, station 01144000

20. Distribution of $A$, Dissolved nitrite plus nitrate, $B$, Total ammonia plus organic nitrogen, $C$, Total nitrogen, $D$, Total phosphorus concentrations relative to streamflow, and $E$, Instantaneous total nitrogen load relative to time for White River at West Hartford, VT, station 01144000

21. $A$, Total nitrogen load, by year, and $B$, Mean annual total nitrogen yield (2003-05) for White River at West Hartford, VT, station 01144000, in relation to all other river sampling sites

22. Map showing location, land-use classification, and photograph of urban area upstream of sampling site for Sugar River at West Claremont, NH, station 01152500 ....35

23-25. Graphs showing-

23. A, Historical and study-period annual streamflow, and $B$, Daily mean streamflow and time distribution of water-quality samples for Sugar River at West Claremont, NH, station 01152500

24. Distribution of $A$, Dissolved nitrite plus nitrate, $B$, Total ammonia plus organic nitrogen, $C$, Total nitrogen, $D$, Total phosphorus concentrations relative to streamflow, and $E$, Instantaneous total nitrogen load relative to time for Sugar River at West Claremont, NH, station 01152500.

25. $A$, Total nitrogen load, by year, and $B$, Mean annual total nitrogen yield (2003-05) for Sugar River at West Claremont, NH, station 01152500, in relation to all other river sampling sites

26. Map showing location, land-use classification, and photograph of sampling site for Connecticut River at North Walpole, NH, station 01154500.

27-29. Graphs showing-

27. A, Historical and study-period annual streamflow, and $B$, Daily mean streamflow and time distribution of water-quality samples for Connecticut River at North Walpole, NH, station 01154500

28. Distribution of $A$, Dissolved nitrite plus nitrate, $B$, Total ammonia plus organic nitrogen, $C$, Total nitrogen, $D$, Total phosphorus concentrations relative to streamflow, and $E$, Instantaneous total nitrogen load relative to time for Connecticut River at North Walpole, NH, station 01154500

29. $A$, Total nitrogen load, by year, and $B$, Mean annual total nitrogen yield (2003-05) for Connecticut River at North Walpole, NH, station 01154500, in relation to all other river sampling sites 
30. Map showing location, land-use cover classification, and photograph of sampling site for Otter River at Otter River, MA, station 01163200

31-33. Graphs showing-

31. A, Historical and study-period annual streamflow, and $B$, Daily mean streamflow and time distribution of water-quality samples for Otter River at Otter River, MA, station 01163200

32. Distribution of $A$, Dissolved nitrite plus nitrate, $B$, Total ammonia plus organic nitrogen, $C$, Total nitrogen, $D$, Total phosphorus concentrations relative to streamflow, and $E$, Instantaneous total nitrogen load relative to time for Otter River at Otter River, MA, station 01163200

33. $A$, Total nitrogen load, by year, and $B$, Mean annual total nitrogen yield (2003-05) for Otter River at Otter River, MA, station 01163200, in relation to all other river sampling sites.

34. Map showing location, land-use classification, and photograph of sampling site for North River at Shattuckville, MA, station 01169000

35-37. Graphs showing-

35. A, Historical and study-period annual streamflow, and $B$, Daily mean streamflow and time distribution of water-quality samples for North River at Shattuckville, MA, station 01169000 .

36. Distribution of $A$, Dissolved nitrite plus nitrate, $B$, Total ammonia plus organic nitrogen, $C$, Total nitrogen, $D$, Total phosphorus concentrations relative to streamflow, and $E$, Instantaneous total nitrogen load relative to time for North River at Shattuckville, MA, station 01169000.

37. $A$, Total nitrogen load, by year, and $B$, Mean annual total nitrogen yield (2003-05) for North River at Shattuckville, MA, station 01169000, in relation to all other river sampling sites.

38. Map showing location, land-use classification, and photograph of sampling site for South River near Conway, MA, station 01169900 .55

39-41. Graphs showing-

39. A, Historical and study-period annual streamflow, and $B$, Daily mean streamflow and time distribution of water-quality samples for South River near Conway, MA, station 01169900.

40. Distribution of $A$, Dissolved nitrite plus nitrate, $B$, Total ammonia plus organic nitrogen, $C$, Total nitrogen, $D$, Total phosphorus concentrations relative to streamflow, and $E$, Instantaneous total nitrogen load relative to time for South River near Conway, MA, station 01169900.

41. $A$, Total nitrogen load, by year, and $B$, Mean annual total nitrogen yield (2003-05) for South River near Conway, MA, station 01169900, in relation to all other river sampling sites.

42. Map showing location, land-use classification, and photograph of sampling site for Green River near Colrain, MA, station 01170100

43-45. Graphs showing-

43. A, Historical and study-period annual streamflow, and $B$, Daily mean streamflow and time distribution of water-quality samples for Green River near Colrain, MA, station 01170100

44. Distribution of $A$, Dissolved nitrite plus nitrate, $B$, Total ammonia plus organic nitrogen, $C$, Total nitrogen, $D$, Total phosphorus concentrations relative to streamflow, and $E$, Instantaneous total nitrogen load relative to time for Green River near Colrain, MA, station $01170100 .$. 
45. $A$, Total nitrogen load, by year, and $B$, Mean annual total nitrogen yield (2003-05) for Green River near Colrain, MA, station 01170100, in relation to all other river sampling sites.

46. Map showing location, land-use classification, and photograph of sampling site for Mill River at Northampton, MA, station 01171500

47-49. Graphs showing-

47. A, Historical and study-period annual streamflow, and $B$, Daily mean streamflow and time distribution of water-quality samples for Mill River at Northampton, MA, station 01171500

48. Distribution of $A$, Dissolved nitrite plus nitrate, $B$, Total ammonia plus organic nitrogen, $C$, Total nitrogen, $D$, Total phosphorus concentrations relative to streamflow, and $E$, Instantaneous total nitrogen load relative to time for Mill River at Northampton, MA, station 01171500.

49. A, Total nitrogen load, by year, and $B$, Mean annual total nitrogen yield (2003-05) for Mill River at Northampton, MA, station 01171500, in relation to all other river sampling sites

50. Map showing location, land-use classification, and photograph of sampling site for Connecticut River at Thompsonville, CT, station 01184000

51-55. Graphs showing-

51. A, Historical and study-period annual streamflow, and $B$, Daily mean streamflow and time distribution of water-quality samples for Connecticut River at Thompsonville, CT, station 01184000.

52. Distribution of $A$, Dissolved nitrite plus nitrate, $B$, Total ammonia plus organic nitrogen, $C$, Total nitrogen, $D$, Total phosphorus concentrations relative to streamflow, and $E$, Instantaneous total nitrogen load relative to time for Connecticut River at Thompsonville, CT, station 01184000 ..

53. $A$, Total nitrogen load, by year, and $B$, Mean annual total nitrogen yield (2003-05) for Connecticut River at Thompsonville, CT, station 01184000, in relation to all other river sampling sites

54. A, Mean total nitrogen concentration, and $B$, Instantaneous mean total nitrogen load for wastewater-treatment sampling sites in the upper Connecticut River Basin in New Hampshire, Vermont, and Massachusetts

55. A, Total nitrogen concentrations among site types in the upper Connecticut River Basin in New Hampshire, Vermont, and Massachusetts

\section{Tables}

1. Selected characteristics for the study sampling sites in the upper Connecticut River Basin in New Hampshire, Vermont, and Massachusetts

2. Mean annual loads, yields, confidence intervals, standard error of prediction, and the ratio of the standard error of prediction to the mean annual load for total nitrogen and total phosphorus at river sampling sites in the upper Connecticut River Basin in New Hampshire, Vermont, and Massachusetts

3. Selected characteristics and summary statistics for concentrations of total nitrogen and instantaneous loads of total nitrogen for the wastewater-treatment sampling sites in the upper Connecticut River Basin in New Hampshire, Vermont, and Massachusetts. 


\section{Conversion Factors, Datums, and Abbreviated Water-Quality Units}

\begin{tabular}{lll}
\hline \multicolumn{1}{c}{ Multiply } & By & \multicolumn{1}{c}{ To obtain } \\
\hline inch (in.) & \multicolumn{1}{c}{ Length } & \\
foot (ft) & 2.54 & centimeter $(\mathrm{cm})$ \\
mile (mi) & 0.3048 & meter $(\mathrm{m})$ \\
& 1.609 & kilometer $(\mathrm{km})$ \\
\hline acre & Area & \\
square foot $\left(\mathrm{ft}^{2}\right)$ & 0.004047 & square kilometer $\left(\mathrm{km}^{2}\right)$ \\
square mile $\left(\mathrm{mi}^{2}\right)$ & 0.09290 & square meter $\left(\mathrm{m}^{2}\right)$ \\
\hline & 2.590 & square kilometer $\left(\mathrm{km}^{2}\right)$ \\
\hline cubic foot per second $\left(\mathrm{ft}{ }^{3} / \mathrm{s}\right)$ & Flow rate & \\
\hline & 0.02832 & cubic meter per second $\left(\mathrm{m}^{3} / \mathrm{s}\right)$ \\
\hline pound per year $(\mathrm{lb} / \mathrm{yr})$ & Weight & \\
pound per square $\mathrm{mile}\left(\mathrm{lb} / \mathrm{mi}^{2}\right)$ & 0.4536 & kilogram per year $(\mathrm{kg} / \mathrm{yr})$ \\
\hline
\end{tabular}

Temperature in degrees Celsius $\left({ }^{\circ} \mathrm{C}\right)$ may be converted to degrees Fahrenheit $\left({ }^{\circ} \mathrm{F}\right)$ as follows:

$$
{ }^{\circ} \mathrm{F}=\left(1.8 \times{ }^{\circ} \mathrm{C}\right)+32
$$

Vertical coordinate information is referenced to the North American Vertical Datum of 1988 (NAVD 88).

Horizontal coordinate information is referenced to the North American Datum of 1983 (NAD 83).

Specific conductance is given in microsiemens per centimeter at 25 degrees Celsius $(\mu \mathrm{S} / \mathrm{cm}$ at $\left.25^{\circ} \mathrm{C}\right)$.

Abbreviated water-quality units used in this report: Chemical concentrations in water are reported in milligrams per liter (mg/L). Milligrams per liter is a unit expressing the concentration of chemical constituents as weight (milligrams) of chemical per unit volume (liter) of water. 


\title{
Assessment of Total Nitrogen in the Upper Connecticut River Basin in New Hampshire, Vermont, and Massachusetts, December 2002-September 2005
}

\author{
By Jeffrey R. Deacon'1, Thor E. Smith', Craig M. Johnston'1, Richard B. Moore', Rebecca M. Weidman², and \\ Laura J. Blake ${ }^{2}$
}

\section{Abstract}

A study of total nitrogen concentrations and loads was conducted from December 2002 to September 2005 at 13 river sites in the upper Connecticut River Basin. Ten sites were selected to represent contributions of nitrogen from forested, agricultural, and urban land. Three sites were distributed spatially on the main stem of the Connecticut River to assess the cumulative total nitrogen loads. To further improve the understanding of the sources and concentrations and loads of total nitrogen in the upper Connecticut River Basin, ambient surface water-quality sampling was supplemented with sampling of effluent from 19 municipal and paper mill wastewatertreatment facilities.

Mean concentrations of total nitrogen ranged from 0.19 to 2.8 milligrams per liter $(\mathrm{mg} / \mathrm{L})$ at river sampling sites. Instantaneous mean loads of total nitrogen ranged from 162 to 58,300 pounds per day (lb/d). Estimated mean annual loads of total nitrogen ranged from 49,100 to 21.6 million pounds per year (lb/yr) with about 30 to 55 percent of the loads being transported during the spring. The estimated mean annual yields of total nitrogen ranged from 1,190 to 7,300 pounds per square mile per year $\left(\mathrm{lb} / \mathrm{mi}^{2}\right) / \mathrm{yr}$.

Mean concentrations of total nitrogen ranged from 4.4 to $30 \mathrm{mg} / \mathrm{L}$ at wastewater-treatment sampling sites. Instantaneous mean loads of total nitrogen from municipal wastewater-treatment facilities ranged from 36 to $1,780 \mathrm{lb} / \mathrm{d}$. Instantaneous mean loads of total nitrogen from paper mill wastewatertreatment facilities ranged from 96 to $160 \mathrm{lb} / \mathrm{d}$.

The median concentration of total nitrogen was $0.24 \mathrm{mg} / \mathrm{L}$ at forested sites, $0.48 \mathrm{mg} / \mathrm{L}$ at agricultural sites, $0.54 \mathrm{mg} / \mathrm{L}$ at urban sites, $0.48 \mathrm{mg} / \mathrm{L}$ at main-stem sites, and $14 \mathrm{mg} / \mathrm{L}$ at wastewater-treatment sites. Concentrations of total nitrogen at forested sites were significantly less than at all

${ }^{1}$ U.S. Geological Survey, New Hampshire/Vermont Water Science Center, Pembroke, New Hampshire.

${ }^{2}$ New England Interstate Water Pollution Control Commission, Lowell, Massachusetts. other site types $(p<0.05)$. Concentrations of total nitrogen at agricultural, urban, and main stem sites were not significantly different among each other ( $p>0.05$ ) but were significantly greater $(p<0.05)$ than at forested sites and significantly less than concentrations at wastewater-treatment sites $(\mathrm{p}<0.05)$. Total nitrogen concentrations at wastewater-treatment sites were significantly different from all other site types $(\mathrm{p}<0.05)$.

Annual yields of total nitrogen ranged from 732 to $1,920\left(\mathrm{lb} / \mathrm{mi}^{2}\right) / \mathrm{yr}$ at forested sites; 1,550 to $2,980\left(\mathrm{lb} / \mathrm{mi}^{2}\right) / \mathrm{yr}$ at agricultural sites; 1,280 to $1,860\left(\mathrm{lb} / \mathrm{mi}^{2}\right) / \mathrm{yr}$ at urban sites that were not directly affected by wastewater effluent; 7,090 to $7,770\left(\mathrm{lb} / \mathrm{mi}^{2}\right) / \mathrm{yr}$ at an urban site directly affected by wastewater effluent; and 1,300 to 2,390 (lb/mi')/yr at main-stem sites.

In this study, the mean annual load and yield of total nitrogen at the Connecticut River at Wells River, VT, was estimated at 4.47 million $\mathrm{lb} / \mathrm{yr}$ and $1,690\left(\mathrm{lb} / \mathrm{mi}^{2}\right) / \mathrm{yr}$, respectively. The mean annual load and yield of total nitrogen at the Connecticut River at North Walpole, $\mathrm{NH}$, was estimated at 9.60 million $\mathrm{lb} / \mathrm{yr}$ and $1,750\left(\mathrm{lb} / \mathrm{mi}^{2}\right) / \mathrm{yr}$, respectively. The mean annual load and yield of total nitrogen leaving the upper Connecticut River Basin, as estimated at the Connecticut River at Thompsonville, CT, was 21.6 million lb/yr and $2,230\left(\mathrm{lb} / \mathrm{mi}^{2}\right) / \mathrm{yr}$, respectively.

\section{Introduction}

A long-term study was initiated in 1985 to protect and restore the health of Long Island Sound (LIS) (U.S. Environmental Protection Agency, State of Connecticut, State of New York, Interstate Sanitation Commission, National Oceanic and Atmospheric Administration, 1985; New York Department of Environmental Conservation/Connecticut Department of Environmental Protection, 2000). Low concentrations (less than $3.5 \mathrm{mg} / \mathrm{L}$ ) of dissolved oxygen (hypoxia) as a result of nitrogen enrichment often occur during the summer in the western part of LIS. Excess nitrogen levels can lead to the enhanced growth of algae, which eventually die and decay, consuming oxygen in the process. The ensuing hypoxic conditions have 
resulted in the exceedance of water-quality standards in LIS during the summer, with oxygen levels often falling below 1 or $2 \mathrm{mg} / \mathrm{L}$. Nitrogen sources include nonpoint-source runoff from agricultural and urban areas, atmospheric deposition of nitrogen, and direct and indirect discharges from wastewater (Mullaney and others, 2002).

In response to this problem, Connecticut and New York developed a Total Maximum Daily Load (TMDL) that specifies the maximum amount of nitrogen that can be discharged to LIS. According to the TMDL analysis, an annual baseline load of about 53,300 tons of nitrogen is delivered to LIS from all sources in Connecticut and New York combined. An additional estimated 13,600 tons of nitrogen reach LIS annually from the part of the Connecticut River Basin originating north of the State of Connecticut. Of this total load, an estimated 12,500 tons of nitrogen is delivered to LIS by way of the Connecticut River. Total nitrogen loads account for terrestrial, atmospheric, and effluent from wastewater-treatment facilities. The TMDL specifies a 58.5-percent reduction in human-generated nitrogen from point and nonpoint sources. The TMDL requires Connecticut to remove about 6,300 tons of nitrogen delivered to LIS each year from wastewater dischargers located throughout the State, as well as another 400 tons of nitrogen resulting from nonpoint sources. The required nitrogen load reduction from wastewater discharge and other sources in New York is about 17,200 tons per year.

The LIS TMDL also specifies the need for additional actions beyond the nitrogen load reductions in Connecticut and New York. In particular, nitrogen reduction actions are needed for other sources, including sources of nitrogen that originate in States north of Connecticut (New Hampshire, Vermont, and Massachusetts) that drain to LIS.

The New England Interstate Water Pollution Control Commission (NEIWPCC) is assisting the U.S. Environmental Protection Agency (USEPA) and the States of Connecticut, Massachusetts, New Hampshire, and Vermont to better define nitrogen sources and loads in the upper Connecticut River Basin (drainage basin upstream from the ConnecticutMassachusetts state line). In order to define these sources, current data on nitrogen concentrations and loads are needed. To assess the current nitrogen loads, the U.S. Geological Survey (USGS), in cooperation with the NEIWPCC, designed and operated a surface water-quality monitoring network from December 2002 to September 2005 to collect water-quality and streamflow data to determine the current concentrations and loads of nitrogen from selected sites representing different land uses and from sites representing effluent from wastewater treatment in the upper Connecticut River Basin.

\section{Purpose and Scope}

This report summarizes concentrations of total nitrogen and other water-quality constituent data collected at 13 river sites and 19 wastewater-treatment sites in the upper Connecti- cut River Basin. Estimates of mean annual load and yield of total nitrogen from river sites and total nitrogen data relative to land use and land-cover classification also are included.

Twelve river sites and 19 wastewater-treatment sites were sampled in New Hampshire, Vermont, and Massachusetts, and one river site was sampled in Connecticut on the Connecticut River at Thompsonville, CT. All river water-quality sampling sites were co-located with a USGS streamflow-gaging station (referred to as a "station" in this report). References made to land use in the remaining sections of this report include land use and land cover. Field measurements of streamflow, specific conductance, $\mathrm{pH}$, water temperature, and concentrations of dissolved oxygen, and nitrogen, phosphorus, and suspended-sediment data are presented in the report. The primary focus of this report is the assessment of concentrations, loads, and yields of total nitrogen at selected sites; however, concentrations, loads, and yields of total phosphorus and concentrations of other water-quality constituents also are presented.

\section{Previous Studies}

Several previous studies have provided estimates of nitrogen and phosphorus loads in the Connecticut River Basin and in the northeastern United States. Trench (1999) provides a summary of total nitrogen and total phosphorus loads for 25 monitoring stations in the Connecticut River Basin through 1995. The estimated load of total nitrogen ranged from 15 million pounds in 1995 to about 41 million pounds in 1984 at the USGS Connecticut River at Thompsonville, CT, water-quality monitoring station. That study also estimates yields of total nitrogen and total phosphorus for basins representing urban, agricultural, and forested land use. The estimated yields of total nitrogen at the USGS Connecticut River at Thompsonville, CT, water-quality monitoring station ranged from 1,550 pounds per square mile in 1995 to 4,210 pounds per square mile in 1984. Mullaney and others (2002) estimated annual loads of nonpoint nitrogen for 1988-98 at 28 monitoring stations and 26 unmonitored basins that drain to LIS. A multiple-linear regression equation was developed, on the basis of total nitrogen yields and associated basin characteristics from monitored sites and applied to unmonitored and other monitored sites, for estimating nonpoint nitrogen yields. The estimated nonpoint nitrogen load to LIS ranged from 21 million pounds in 1995 to 50 million pounds in 1990 (Mullaney and others, 2002). Mullaney (2004) provides a summary of water-quality trends in the Connecticut River, including trends in concentrations of total nitrogen. Since 1988, downward trends in total nitrogen were observed at the long-term USGS water-quality monitoring station at Connecticut River at Thompsonville, CT. The downward trend likely is a result of improved nitrogen removal from wastewater-treatment facilities but may relate to changes in land use, such as agricultural land changing to residential or forested land (Mullaney, 2004). 
Regional nitrogen modeling studies include application of the USGS New England Spatially Referenced Regression on Watershed Attributes (SPARROW) model, which uses regression equations to relate total nitrogen stream loads to nutrient sources and watershed characteristics. Significant predictor variables of total nitrogen included (1) nitrogen loadings from permitted municipal wastewater discharge, (2) atmospheric deposition, (3) the area of agricultural land, and (4) the area of urban land (Moore and others, 2004). The estimated total nitrogen load at the mouth of the Connecticut River for 1992-93 was 17,800 tons. The estimated total nitrogen load at the Connecticut River at Thompsonville, CT, was 14,100 tons for 1992-93. Results of simulations made with the SPARROW model also indicated that total nitrogen stream-loss rates were significant only in streams with average annual flows less than or equal to 100 cubic feet per second $\left(\mathrm{ft}^{3} / \mathrm{s}\right)$. Seitzinger and others (2002) developed a regression model that predicts the amount of nitrogen removed from rivers and its application to drainages in the northeastern United States. Results from this study indicated that as much as 37 to 76 percent of nitrogen inputs to rivers is removed during transport and about half of that is removed in first- to fourth-order streams, accounting for 90 percent of the total stream length in the basins.

Mueller and others (1995) compiled historical data on nutrient concentrations (nitrogen and phosphorus) from 20 study units of the USGS National Water-Quality Assessment Program. More than 220,000 surface-water samples were analyzed on regional and national scales. Results of the study indicated that nutrient concentrations in surface water generally were related to land use. Nitrate concentrations were highest in samples from sites downstream from agricultural or urban areas. Results also indicated the elevated concentrations of nitrate in surface water in the northeastern United States may be related to large amounts of atmospheric deposition.

\section{Description of the Study Area}

The Connecticut River Basin, the largest in New England, encompasses 11,250 square miles (mi ${ }^{2}$ ) (fig. 1). The Connecticut River traverses 410 miles (mi) from its headwaters near the New Hampshire-Canada border to its mouth in Old Saybrook, CT, where it drains into Long Island Sound. The river drops 2,400 feet (ft) in elevation from its source to its outlet, and has an estimated average discharge of about $19,200 \mathrm{ft}^{3} / \mathrm{s}$ at the outlet (Garabedian and others, 1998). The Connecticut River makes up 70 percent of the freshwater flow into LIS .

Elevations in the Connecticut River Basin range from sea level in coastal Connecticut to $6,288 \mathrm{ft}$ above sea level at the peak of Mount Washington in the White Mountains of New Hampshire. Topography is characterized by rolling hills and low, rounded mountains with numerous, generally narrow valleys. The relief is greatest in the northern part of the basin where the Green Mountains of Vermont and the White Mountains of New Hampshire generally reach elevations between 2,000 and 4,000 ft above sea level. The Connecticut River valley forms a broad lowland just south of the New Hampshire-Vermont-Massachusetts state lines to within about $20 \mathrm{mi}$ of LIS (Grady and Garabedian, 1991).

Average annual temperatures range from less than 5 degrees Celsius $\left({ }^{\circ} \mathrm{C}\right)$ in the northern mountainous regions to about $10^{\circ} \mathrm{C}$ in the southern regions. Average annual precipitation ranges from about 34 inches (in.) in the northern areas of the Connecticut River Basin to more than 65 in. in some of the mountainous regions (Garabedian and others, 1998).

For purposes of this report, the upper Connecticut River Basin is defined as the drainage basin above the USGS streamgaging station at Connecticut River at Thompsonville, CT (site 13, fig. 1). The station is near the ConnecticutMassachusetts State line and serves as the outlet site to the upper basin. Streamflow at the station averages about $12,700 \mathrm{ft}^{3} / \mathrm{s}$. The upper Connecticut River Basin encompasses approximately 9,660 $\mathrm{mi}^{2}$ in New Hampshire, Vermont, and Massachusetts (fig. 1). The population is approximately 1 million people and is distributed amongst densely populated, urban areas in the southernmost section of the basin in Massachusetts to sparsely populated, rural and agricultural regions in the northern areas of the basin in New Hampshire and Vermont. The agricultural land use in New Hampshire and Vermont is predominantly related to dairy farm operations. The agricultural land use in Massachusetts is predominantly related to orchards, row crops, and some dairy operations. The land use and land cover in the upper basin consists of about 80 percent forest, 9 percent agriculture, 5 percent urban, and 6 percent wetlands and barren.

\section{Data Collection and Analysis}

Data were collected for this study to improve the understanding of current total nitrogen concentrations and loads at selected sites and to estimate the contributions originating from different land uses and the effluent from wastewater-treatment facilities in the basin. Field measurements of streamflow, specific conductance, $\mathrm{pH}$, water temperature, and concentrations of dissolved oxygen, were made, and nitrogen, phosphorus, and suspended-sediment concentration data were collected. Total nitrogen was calculated as the sum of nitrite plus nitrate and total ammonia plus organic nitrogen.

\section{Site Selection}

Approximately 80 stream sites initially were considered as potential sampling sites. The sites were categorized by stream size, percentage of land-use types, and estimated total nitrogen loads from the New England SPARROW model (Moore and others, 2004). The final selection of the sites was based on topographic map inspections and field reconnaissance, the existing USGS streamgaging network in the upper Connecticut River Basin, and whether water-quality data had previously been collected at the site. The process also 


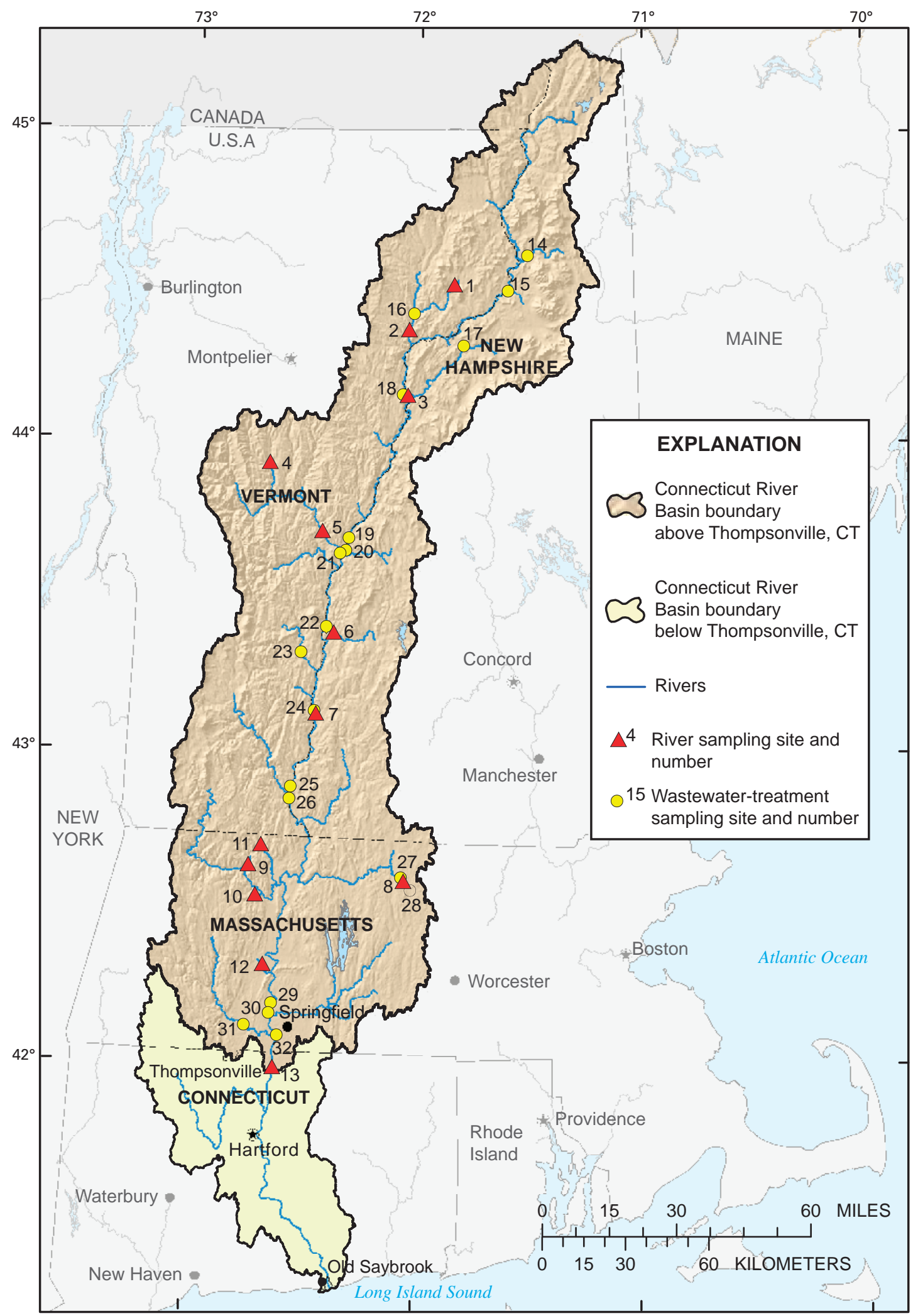

Shaded relief from U.S. Geological Survey 30-meter National Elevation Dataset, 1999

Figure 1. Sampling sites and site-identification numbers in the upper Connecticut River Basin in New Hampshire, Vermont, and Massachusetts. (Site identification numbers are shown in table 1.) 
included an analysis of the New England SPARROW model results that estimated the percentage of land-use classifications contributing nitrogen to the stream site. Thirteen river sites were selected for the study (table 1, fig. 1). Ten sites were selected to represent contributions of nitrogen from forested, agricultural, and urban land. Forest was the predominant land use at all sites in the basin. Sites that were selected to represent agricultural and urban land use in this study generally had agriculture and urban land use as the second predominant land use in the basin. Three sites were distributed spatially on the main stem of the Connecticut River. The Connecticut River at Thompsonville, CT, was sampled as part of the USGS Connecticut Water Science Center programs.

Ambient water-quality sampling at river sites was supplemented with the collection of effluent samples from 19 wastewater-treatment facilities in New Hampshire, Vermont, and Massachusetts (table 1, fig. 1). Sixteen sampling sites were located at municipal wastewater-treatment facilities and three sites were located at paper mill wastewater-treatment facilities. The facilities were selected on the basis of size, type, and location in the basin. The samples of effluent from wastewater-treatment facilities, referred to as wastewatertreatment sampling sites in this report, will provide an estimate of the contribution of total nitrogen from the effluent from these facilities.

\section{Sample Collection}

Samples were collected monthly from December 2002 through September 2005 at each of the 13 river sites by using field procedures outlined in Wilde and Radtke (1998a,b). Forty to 45 water samples were collected at each river sampling site. Samples were collected in baseflow, periodic rainstorm, and snowmelt conditions. About three additional samples were collected during the snowmelt runoff period each year to characterize the period when constituent concentrations might be more variable. Ten to 15 samples were collected at the wastewater-treatment sampling sites, generally from April through September, to assist in providing current total nitrogen data from the effluent from these facilities. During each site visit, onsite measurements were made for specific conductance, $\mathrm{pH}$, water temperature, and concentrations of dissolved oxygen, and water samples were collected for subsequent laboratory analysis of the concentrations of dissolved nitrite plus nitrate, dissolved ammonia, total ammonia plus organic nitrogen, dissolved orthophosphate, total phosphorus, and suspended-sediment. Instantaneous streamflow was determined at the time of sample collection using established USGS stage-discharge relations at streamgaging stations for river sites and from the facilities gage at wastewater-treatment sites. Water samples were analyzed at the USGS water-quality laboratory in Lakewood, CO. Suspended-sediment concentration analysis was conducted at the USGS Kentucky sediment laboratory in Louisville, KY. All data are available from the USGS National
Water Information System (NWIS) database and are published in USGS annual Water-Data Reports (Keirstead and others, 2003, 2004; Kiah and others, 2005; Socolow and others, 2003, 2004, 2005).

\section{Data Analysis}

Selected results of the data collection and water-quality analyses for each of the 13 river sampling sites are presented in the following sections. For each river site, water-quality conditions are described, and a map and three pages of graphs of selected data are presented. Ranges of constituent values not plotted in the graphs are statistically summarized in the text. For nitrite, ammonia, and orthophosphate summary statistics, data were re-censored from the laboratory reporting level (LRL) to the long-term method detection level (LT-MDL). Recensoring provides useful information for constituents that are censored at the laboratory reporting level but have qualified values between the LT-MDL and the LRL (Helsel, 2005). For nitrite, the LRL was $0.008 \mathrm{mg} / \mathrm{L}$ and the LT-MDL was $0.004 \mathrm{mg} / \mathrm{L}$; therefore, nitrite data were re-censored at $0.004 \mathrm{mg} / \mathrm{L}$. For ammonia, the LRL was $0.010 \mathrm{mg} / \mathrm{L}$ and the LT-MDL was $0.005 \mathrm{mg} / \mathrm{L}$; therefore, ammonia was recensored at $0.005 \mathrm{mg} / \mathrm{L}$. For orthophosphate in the years 2003 and 2004, the LRL was $0.02 \mathrm{mg} / \mathrm{L}$ and the LT-MDL was $0.01 \mathrm{mg} / \mathrm{L}$; therefore, orthophosphate was re-censored at $0.01 \mathrm{mg} / \mathrm{L}$ for data collected in 2003 and 2004. Orthophosphate was analyzed at a lower level during 2005 when the LRL was $0.006 \mathrm{mg} / \mathrm{L}$ and the LT-MDL was $0.003 \mathrm{mg} / \mathrm{L}$; therefore, orthophosphate was re-censored at $0.003 \mathrm{mg} / \mathrm{L}$ for data collected in 2005. Long-term method detection and laboratory reporting levels for samples analyzed at the USGS National Water Quality Laboratory are described by Childress and others (1999).

For each river site, the illustrations begin with a map of the site showing the major stream network and the land-use classifications (U.S. Geological Survey, 2000). Information about land use assists in the understanding of natural and anthropogenic factors that affect water quality. Two graphs are presented on the second page of illustrations to describe the streamflow and the distribution of water-quality samples in relation to streamflow. In the first graph, annual streamflow is described by use of a bar chart. Streamflow for each water year of the study period is represented by one bar in the graph. A water year is the period from October through September and is defined by the year in which it ends. Historical data also are provided for the period prior to data collection for this study. A comparison of historical data to data collected for this study indicates in general terms whether runoff during the data-collection period was above average, below average, or normal. In the second graph, daily mean streamflow for the data-collection period as well as dates and instantaneous streamflow for the water-quality samples are presented. Because the water-quality samples are displayed with the corresponding instantaneous streamflow, these points do not 
Table 1. Selected characteristics for the study sampling sites in the upper Connecticut River Basin in New Hampshire, Vermont, and Massachusetts.

[USGS, U.S. Geological Survey; mi² $^{2}$ square miles; WY, water year; na, not applicable; WWTF, wastewater-treatment facility; --, no data]

\begin{tabular}{|c|c|c|c|c|c|c|c|c|}
\hline $\begin{array}{c}\text { Site } \\
\text { num- } \\
\text { ber } \\
\text { (fig. 1) }\end{array}$ & $\begin{array}{l}\text { USGS station } \\
\text { number }\end{array}$ & Station name & $\begin{array}{l}\text { Site type in } \\
\text { this study }\end{array}$ & Latitude & Longitude & $\begin{array}{c}\text { Drainage } \\
\text { area } \\
\left(\mathrm{mi}^{2}\right)\end{array}$ & $\begin{array}{c}\text { Mean } \\
\text { annual } \\
\text { stream- } \\
\text { flow } \\
\text { (WY } \\
\text { 1980-2002) }\end{array}$ & $\begin{array}{c}\text { Mean } \\
\text { annual } \\
\text { stream- } \\
\text { flow } \\
\text { (WY } \\
\text { 2003-05) }\end{array}$ \\
\hline \multicolumn{7}{|c|}{ River sampling sites } & \multicolumn{2}{|c|}{$\begin{array}{l}\text { (in thousands of } \\
\text { acre-feet) }\end{array}$} \\
\hline 1 & 01134500 & Moose River at Victory, VT & Forest & $44^{\circ} 30^{\prime} 42^{\prime \prime}$ & $71^{\circ} 50^{\prime} 13^{\prime \prime}$ & 75.2 & 111 & 107 \\
\hline 2 & 01135500 & $\begin{array}{l}\text { Passumpsic River at } \\
\text { Passumpsic, VT }\end{array}$ & Agriculture & $44^{\circ} 21^{\prime} 56^{\prime \prime}$ & $72^{\circ} 02^{\prime} 23^{\prime \prime}$ & 436 & 572 & 554 \\
\hline 3 & 01138500 & $\begin{array}{l}\text { Connecticut River at } \\
\text { Wells River, VT }\end{array}$ & Main stem & $44^{\circ} 09^{\prime} 13^{\prime \prime}$ & $72^{\circ} 02^{\prime} 34^{\prime \prime}$ & 2,644 & 3,750 & 3,560 \\
\hline 4 & 01142500 & Ayers Brook at Randolph, VT & Agriculture & $43^{\circ} 56^{\prime} 04^{\prime \prime}$ & $72^{\circ} 39^{\prime} 30^{\prime \prime}$ & 30.5 & 37.3 & 38.2 \\
\hline 5 & 01144000 & White River at West Hartford, VT & Agriculture & $43^{\circ} 42^{\prime} 51^{\prime \prime}$ & $72^{\circ} 25^{\prime} 07^{\prime \prime}$ & 690 & 885 & 959 \\
\hline 6 & 01152500 & $\begin{array}{l}\text { Sugar River at West } \\
\text { Claremont, NH }\end{array}$ & Urban & $43^{\circ} 23^{\prime} 15^{\prime \prime}$ & $72^{\circ} 21^{\prime} 45^{\prime \prime}$ & 269 & 304 & 341 \\
\hline 7 & 01154500 & $\begin{array}{l}\text { Connecticut River at North } \\
\text { Walpole, NH }\end{array}$ & Main stem & $43^{\circ} 07^{\prime} 34^{\prime \prime}$ & $72^{\circ} 26^{\prime} 14^{\prime \prime}$ & 5,493 & 7,160 & 7,070 \\
\hline 8 & 01163200 & Otter River at Otter River, MA & Urban & $42^{\circ} 35^{\prime} 18^{\prime \prime}$ & $72^{\circ} 02^{\prime} 29^{\prime \prime}$ & 34.1 & 45.3 & 53.4 \\
\hline 9 & 01169000 & North River at Shattuckville, MA & Agriculture & $42^{\circ} 38^{\prime} 18^{\prime \prime}$ & $72^{\circ} 43^{\prime} 32^{\prime \prime}$ & 89.0 & 138 & 167 \\
\hline 10 & 01169900 & South River near Conway, MA & Agriculture & $42^{\circ} 32^{\prime} 31^{\prime \prime}$ & $72^{\circ} 41^{\prime} 39^{\prime \prime}$ & 24.1 & 37.1 & 48.1 \\
\hline 11 & 01170100 & Green River near Colrain, MA & Forest & $42^{\circ} 42^{\prime} 12^{\prime \prime}$ & $72^{\circ} 40^{\prime} 16^{\prime \prime}$ & 41.4 & 61.4 & 74.4 \\
\hline 12 & 01171500 & Mill River at Northhampton, MA & Urban & $42^{\circ} 19^{\prime} 08^{\prime \prime}$ & $72^{\circ} 39^{\prime} 56^{\prime \prime}$ & 54.0 & 73.0 & 88.4 \\
\hline $13^{\mathrm{a}}$ & 01184000 & $\begin{array}{c}\text { Connecticut River at } \\
\text { Thompsonville, CT } \\
\end{array}$ & Main stem & $41^{\circ} 59^{\prime} 14^{\prime \prime}$ & $72^{\circ} 36^{\prime} 21 "$ & 9,660 & 12,700 & 13,000 \\
\hline
\end{tabular}

\begin{tabular}{|c|c|c|c|c|c|c|c|c|}
\hline \multicolumn{7}{|c|}{ Point-source sampling sites } & \multicolumn{2}{|c|}{ (in millions of gallons) } \\
\hline 14 & 443558071303001 & Wasau Paper WWTF, NH & Point source & $44^{\circ} 35^{\prime} 58^{\prime \prime}$ & $71^{\circ} 30^{\prime} 30^{\prime \prime}$ & na & na & 1,670 \\
\hline 15 & 442906071354401 & Lancaster WWTF, NH & Point source & $44^{\circ} 29^{\prime} 06^{\prime \prime}$ & $71^{\circ} 35^{\prime} 44^{\prime \prime}$ & na & na & -- \\
\hline 16 & 442436072010001 & St. Johnsbury WWTF, VT & Point source & $44^{\circ} 24^{\prime} 36^{\prime \prime}$ & $72^{\circ} 01^{\prime} 00^{\prime \prime}$ & na & na & 407 \\
\hline 17 & 441827071473701 & Littleton WWTF, NH & Point source & $44^{\circ} 18^{\prime} 27^{\prime \prime}$ & $71^{\circ} 47^{\prime} 37^{\prime \prime}$ & na & na & 303 \\
\hline 18 & 440835072022501 & Woodsville WWTF, NH & Point source & $44^{\circ} 08^{\prime} 35^{\prime \prime}$ & $72^{\circ} 02^{\prime 2} 25^{\prime \prime}$ & na & na & 63 \\
\hline 19 & 434145072175601 & Hanover WWTF, NH & Point source & $43^{\circ} 41^{\prime} 45^{\prime \prime}$ & $72^{\circ} 17^{\prime} 56^{\prime \prime}$ & na & na & 531 \\
\hline 20 & 433844072185501 & $\begin{array}{l}\text { Hartford/White River Junction } \\
\text { WWTF, VT }\end{array}$ & Point source & $43^{\circ} 38^{\prime} 44^{\prime \prime}$ & $72^{\circ} 18^{\prime} 55^{\prime \prime}$ & na & na & 365 \\
\hline 21 & 433813072192001 & Lebanon WWTF, NH & Point source & $43^{\circ} 38^{\prime} 13^{\prime \prime}$ & $72^{\circ} 19^{\prime} 20^{\prime \prime}$ & na & na & 659 \\
\hline 22 & 432359072234001 & Claremont WWTF, NH & Point source & $43^{\circ} 23^{\prime} 59^{\prime \prime}$ & $72^{\circ} 23^{\prime} 40^{\prime \prime}$ & na & na & 578 \\
\hline 23 & 431648072280801 & Springfield WWTF, VT & Point source & $43^{\circ} 16^{\prime} 48^{\prime \prime}$ & $72^{\circ} 28^{\prime} 08^{\prime \prime}$ & na & na & -- \\
\hline 24 & 430745072263701 & Bellows Falls WWTF, VT & Point source & $43^{\circ} 07^{\prime} 45^{\prime \prime}$ & $72^{\circ} 26^{\prime} 37^{\prime \prime}$ & na & na & 206 \\
\hline 25 & 425322072323701 & Fibermark Products WWTF, VT & Point source & $42^{\circ} 53^{\prime} 22^{\prime \prime}$ & $72^{\circ} 32^{\prime} 37^{\prime \prime}$ & na & na & 518 \\
\hline 26 & 425029072325901 & Brattleboro WWTF, VT & Point source & $42^{\circ} 50^{\prime} 29^{\prime \prime}$ & $72^{\circ} 32^{\prime} 59^{\prime \prime}$ & na & na & 575 \\
\hline 27 & 423542072031001 & Seaman Paper WWTF, MA & Point source & $42^{\circ} 35^{\prime} 42^{\prime \prime}$ & $72^{\circ} 03^{\prime} 10^{\prime \prime}$ & na & na & 329 \\
\hline 28 & 423413072011201 & Gardner WWTF, MA & Point source & $42^{\circ} 34^{\prime} 13^{\prime \prime}$ & $72^{\circ} 01^{\prime} 12^{\prime \prime}$ & na & na & 1,300 \\
\hline 29 & 421132072365001 & Holyoke WWTF, MA & Point source & $42^{\circ} 11^{\prime} 32^{\prime \prime}$ & $72^{\circ} 36^{\prime} 50^{\prime \prime}$ & na & na & 3,270 \\
\hline 30 & 420908072373301 & Chicopee WWTF, MA & Point source & $42^{\circ} 09^{\prime} 08^{\prime \prime}$ & $72^{\circ} 37^{\prime} 33^{\prime \prime}$ & na & na & 3,590 \\
\hline 31 & 420702072435601 & Westfield WWTF, MA & Point source & $42^{\circ} 07^{\prime} 02^{\prime \prime}$ & $72^{\circ} 43^{\prime} 56^{\prime \prime}$ & na & na & 1,400 \\
\hline 32 & 420508072351401 & Springfield WWTF, MA & Point source & $42^{\circ} 05^{\prime} 08^{\prime \prime}$ & $72^{\circ} 35^{\prime} 14^{\prime \prime}$ & na & na & 15,900 \\
\hline
\end{tabular}

${ }^{a}$ Sampled by the USGS Connecticut Water Science Center. 
always fall on the line representing the daily mean discharge. The distribution of water-quality samples with respect to time also is represented.

The third page of illustrations presents the distribution of selected water-quality constituents at the various sites. Concentrations of selected constituents are shown in relation to streamflow and instantaneous loads of total nitrogen are shown in relation to time. Box plots in the right margins of the graphs summarize the distribution of concentrations or loads for each constituent.

Two bar graphs are presented on the fourth page of illustrations to describe the total nitrogen loads and mean annual yields. The first graph is the estimated total nitrogen load by water year for the river site, and the second graph presents the mean annual nitrogen yield (2003-05) compared to all other river sampling sites.

Selected results of the analysis of total nitrogen in samples collected at the wastewater-treatment sampling sites are presented as summary statistics in the text and as bar graphs in the illustrations. The concentrations of total nitrogen among and in relation to site types are summarized in box plots. The Kruskal-Wallis test, a nonparametric analysis of variance test (ANOVA), was used to determine significant statistical differences among groups of data (Helsel and Hirsch, 1992). The level of significance for ANOVA was set at alpha equals 0.05. When the nonparametric ANOVA indicated significant statistical differences, ranked transformed data were used for the Tukey's multiple comparison test to determine which groups were significantly different (Helsel and Hirsch, 1992). All statistical analyses were performed using Statview and SAS statistical software (SAS Institute, Inc., 1998, 2000).

The LOAD ESTimator (LOADEST) computer program (Runkel and others, 2004) was used to estimate total nitrogen and total phosphorus loads at the study sites. LOADEST is based on a regression equation in which time series of streamflow and constituent concentrations are used as calibration data for the estimation of constituent loads. Explanatory variables within the regression model include various functions of streamflow and time (seasonality). For total nitrogen or total phosphorus at each site, models were fit using all possible combinations of these variables and the best model was selected based on the Akaike Information Criteria (Akaike, 1981). The specific method used for model calibration and load estimation is described by Runkel and others (2004). Data on annual loads, yields, confidence intervals, seasonal load estimates, and the regression equations used in LOADEST for total nitrogen and total phosphorus estimates are in appendix tables A-1 through A-4.

Quality-control procedures included analyses of field blank and replicate samples. Field blanks provide information on bias or the potential for contamination of analytical results by sample collection, processing, and analysis (Spahr and Boulger, 1997). Analyses of the field blank samples indicated that concentrations of constituents discussed in this report were less than the LRL. Replicate samples provide information on the variability of analytical results caused by sample collection, processing, and analysis (Spahr and Boulger, 1997). Differences in concentrations of the constituents of interest in environmental and replicate samples at river sampling sites were within $0.01 \mathrm{mg} / \mathrm{L}$ and $0.05 \mathrm{mg} / \mathrm{L}$ for nitrite plus nitrate and total ammonia plus organic nitrogen, respectively. This resulted in concentration differences in environmental and replicate samples for total nitrogen being within $0.1 \mathrm{mg} / \mathrm{L}$. Differences in concentrations in environmental and replicate samples at wastewatersampling sites, where concentrations generally were greater, were within 10 percent for nitrite plus nitrate and total ammonia plus organic nitrogen. This resulted in differences in environmental and replicate samples for total nitrogen also being within 10 percent. Differences in concentrations in environmental and replicate samples for other constituents discussed in this report were low. It was concluded that sample processing and analysis did not introduce enough variation in the environmental data to affect interpretation of results.

\section{Characterization of Total Nitrogen at River Sampling Sites}

Mean concentrations of total nitrogen at river sampling sites ranged from 0.19 to $2.8 \mathrm{mg} / \mathrm{L}$ and mean instantaneous loads of total nitrogen ranged from 162 to 58,300 pounds per day (lb/d). Estimated mean annual loads of total nitrogen ranged from 49,100 to 21.6 million pounds per year (lb/yr) with about 30 to 55 percent of the load being transported during the spring. The estimated mean annual yields of total nitrogen ranged from 1,190 to $7,300\left(\mathrm{lb} / \mathrm{mi}^{2}\right) / \mathrm{yr}$.

In the following sections, selected constituent concentrations and loads of total nitrogen are summarized in the text and are plotted in graphs to examine relations to streamflow and time at each site. Ranges of field measurement values and other water-quality constituent values are presented in the text. Estimated loads and yields of total nitrogen and total phosphorus at river sampling sites are presented in table 2. The 95-percent confidence intervals of the mean load, the standard error of prediction, and the ratio of the standard error of prediction to the mean load also are presented in table 2. The ratio of the standard error of prediction to the mean load standardizes the model error and provides a comparison among sites having large differences in load estimates. The prediction error ranged from 2.2 to 10 percent of the mean loads for total nitrogen estimates and from 9.7 to 54 percent of the mean loads for total phosphorus estimates. This indicates that the models had low error in the estimates of total nitrogen and more error in the estimates of total phosphorus. 


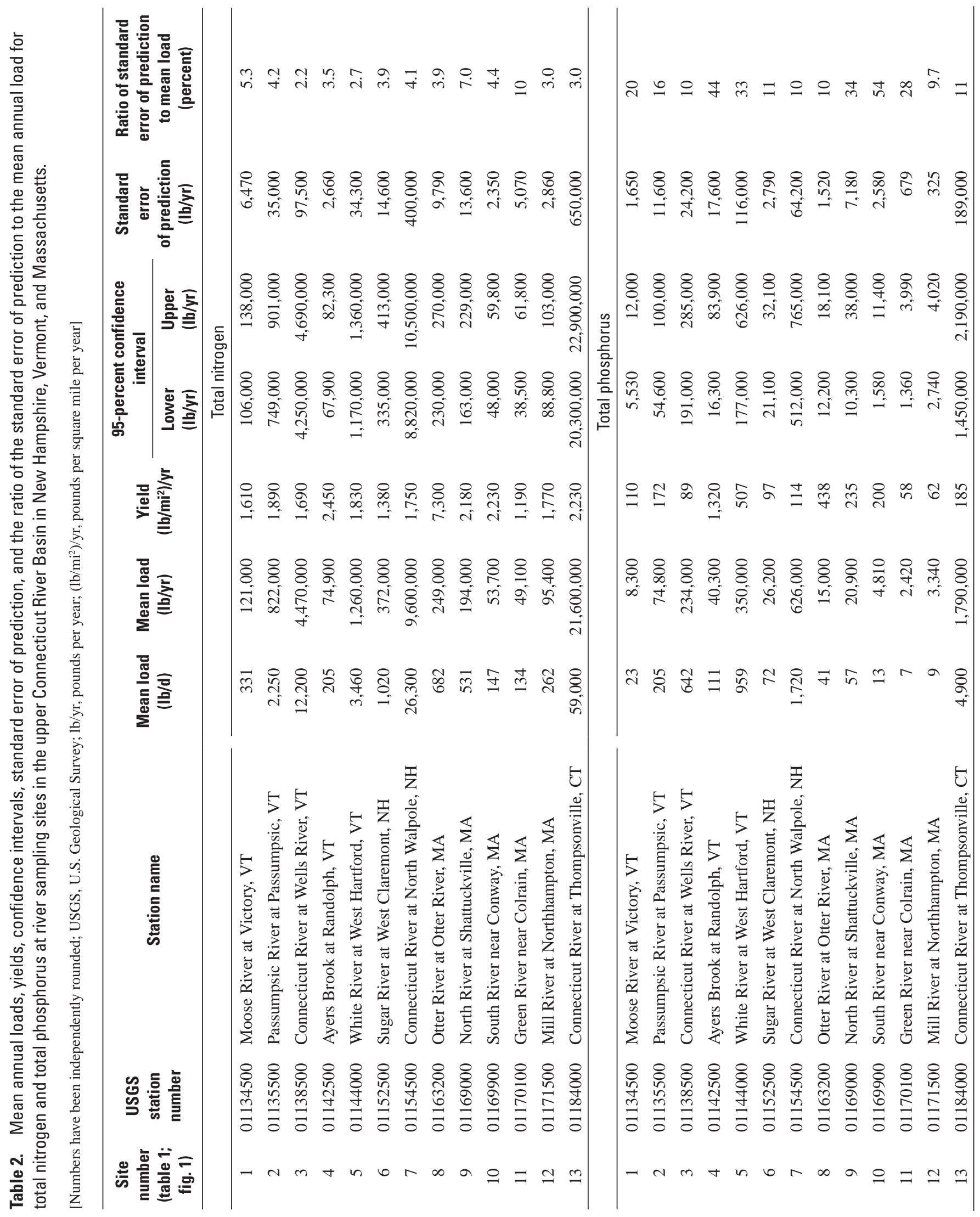




\section{Moose River at Victory, VT, Station 01134500}

Moose River at Victory, VT, represents a forested site in the study area with minimal effects on water quality from land use. The contributing drainage basin upstream from the site encompasses $75 \mathrm{mi}^{2}$ and is about 90 percent forested, 7 percent wetlands, and 3 percent barren (fig. 2). Annual streamflow for 1980-2002 averaged 111,000 acre-feet, with considerable year-to-year variation (fig. 3A). Annual streamflow for the data-collection period for water years 2003-05 averaged 107,000 acre-feet (table 1). Streamflow during the period was less than the long-term mean for the first year of the study period, greater than the long-term mean for the second year, and about equal to the long-term mean for the third year (fig. 3A).

Daily mean streamflow and time distribution for 42 water-quality samples are shown in figure $3 \mathrm{~B}$. The minimum streamflow at which the water samples were collected was $16 \mathrm{ft}^{3} / \mathrm{s}$, and the maximum streamflow at which samples were collected was $721 \mathrm{ft}^{3} / \mathrm{s}$.

The minimum concentration of dissolved oxygen at this site $(7.0 \mathrm{mg} / \mathrm{L})$ equaled the State of Vermont water-quality criterion for Class B waters for dissolved oxygen of $7.0 \mathrm{mg} / \mathrm{L}$ for cold water fish habitat (Vermont Water Resources Board, 2000). Concentrations of selected water-quality constituents were plotted relative to streamflow (fig. 4). Concentrations of dissolved nitrite plus nitrate ranged from an estimated 0.016 to $0.373 \mathrm{mg} / \mathrm{L}$, and showed no apparent relation to streamflow (fig. 4A). Total ammonia plus organic nitrogen ranged from 0.13 to $0.81 \mathrm{mg} / \mathrm{L}$ and also showed no apparent relation to streamflow (fig. 4B). The maximum concentration of total ammonia plus organic nitrogen $(0.81 \mathrm{mg} / \mathrm{L})$ was in a sample collected at a streamflow of $570 \mathrm{ft}^{3} / \mathrm{s}$, just prior to the maximum daily mean streamflow, which occurred during snowmelt in water year 2004 (fig. 4B). Concentrations of total nitrogen (dissolved nitrite plus nitrate plus total ammonia plus organic nitrogen) ranged from 0.20 to $0.90 \mathrm{mg} / \mathrm{L}$ (fig. 4C), with the maximum concentration observed during spring snowmelt in water year 2004. Concentrations of total phosphorus generally were low and ranged from 0.005 to $0.124 \mathrm{mg} / \mathrm{L}$ and showed a slight increase with an increase in streamflow (fig. 4D). The maximum concentration of total phosphorus $(0.124 \mathrm{mg} / \mathrm{L})$ also was collected at a streamflow of $570 \mathrm{ft}^{3} / \mathrm{s}$, just prior to the maximum daily mean streamflow during snowmelt in water year 2004 (fig. 4D). Instantaneous loads of total nitrogen generally were representative of the instantaneous streamflow at the time of sample collection and ranged from 22 to $2,700 \mathrm{lb} / \mathrm{d}$ (fig. 4E). In other words, instantaneous loads of total nitrogen were greater in samples collected during high streamflows and less in samples collected during base-flow or low-flow conditions. Ranges of concentrations or values for water-quality constituents not shown in figure 4 are listed below.

\begin{tabular}{lcccc}
\hline \multirow{2}{*}{$\begin{array}{c}\text { Water-quality } \\
\text { constituent }\end{array}$} & \multicolumn{4}{c}{$<$, less than; - } \\
\cline { 2 - 5 } & $\begin{array}{c}\text { Mini- } \\
\text { mum }\end{array}$ & Mean calculated & Median & $\begin{array}{c}\text { Maxi- } \\
\text { mum }\end{array}$ \\
\hline Specific conductance & 18 & 32 & 31 & 49 \\
$\mathrm{pH}$ & 5.7 & 6.5 & 6.4 & 7.4 \\
Water temperature & .0 & 6.8 & 3.0 & 21.8 \\
Dissolved oxygen & 7.0 & 10.8 & 11.2 & 14.1 \\
Dissolved nitrite & $<.004$ & - & $<.004$ & .005 \\
Dissolved ammonia & .005 & .017 & .013 & .074 \\
Dissolved orthophos- & $<.01$ & - & $<.01$ & $<.01$ \\
$\quad$ phate (WY 2003-04) & & & & \\
Dissolved orthophos- & $<.003$ & - & $<.003$ & .003 \\
$\quad \begin{array}{l}\text { phate (WY 2005) } \\
\text { Suspended sediment }\end{array}$ & 1 & 13 & 3 & 165 \\
\hline
\end{tabular}

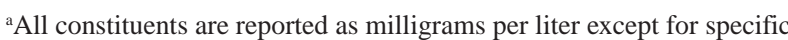
conductance, which is reported as microsiemens per centimeter at 25 degrees Celsius; $\mathrm{pH}$, which is reported as standard units; and water temperature, which is reported as degrees Celsius; WY, water year. < less than; 一, not calculated.

The estimated load of total nitrogen varied among years during the study (appendix A-1; fig. 5A). The mean annual load of total nitrogen was $121,000 \mathrm{lb} / \mathrm{yr}$ with a ratio of the standard error of prediction to the mean load of 5.3 percent (table 2, fig. 5A). An estimated 47 percent of the total nitrogen load was transported during the spring (appendix A-2). The mean total nitrogen yield $\left(1,610\left(\mathrm{lb} / \mathrm{mi}^{2}\right) / \mathrm{yr}\right)$ generally was less than at sites representing other land uses (fig. 5B). Trench (1999) reported similar results in that forested basins generally had lower yields of total nitrogen than agricultural and urban basins of similar size. In general, water quality at this site typifies background conditions for this area of the basin. Concentrations of total nitrogen and other water-quality constituents generally were low. 
Moose River at Victory, VT, Station 01134500

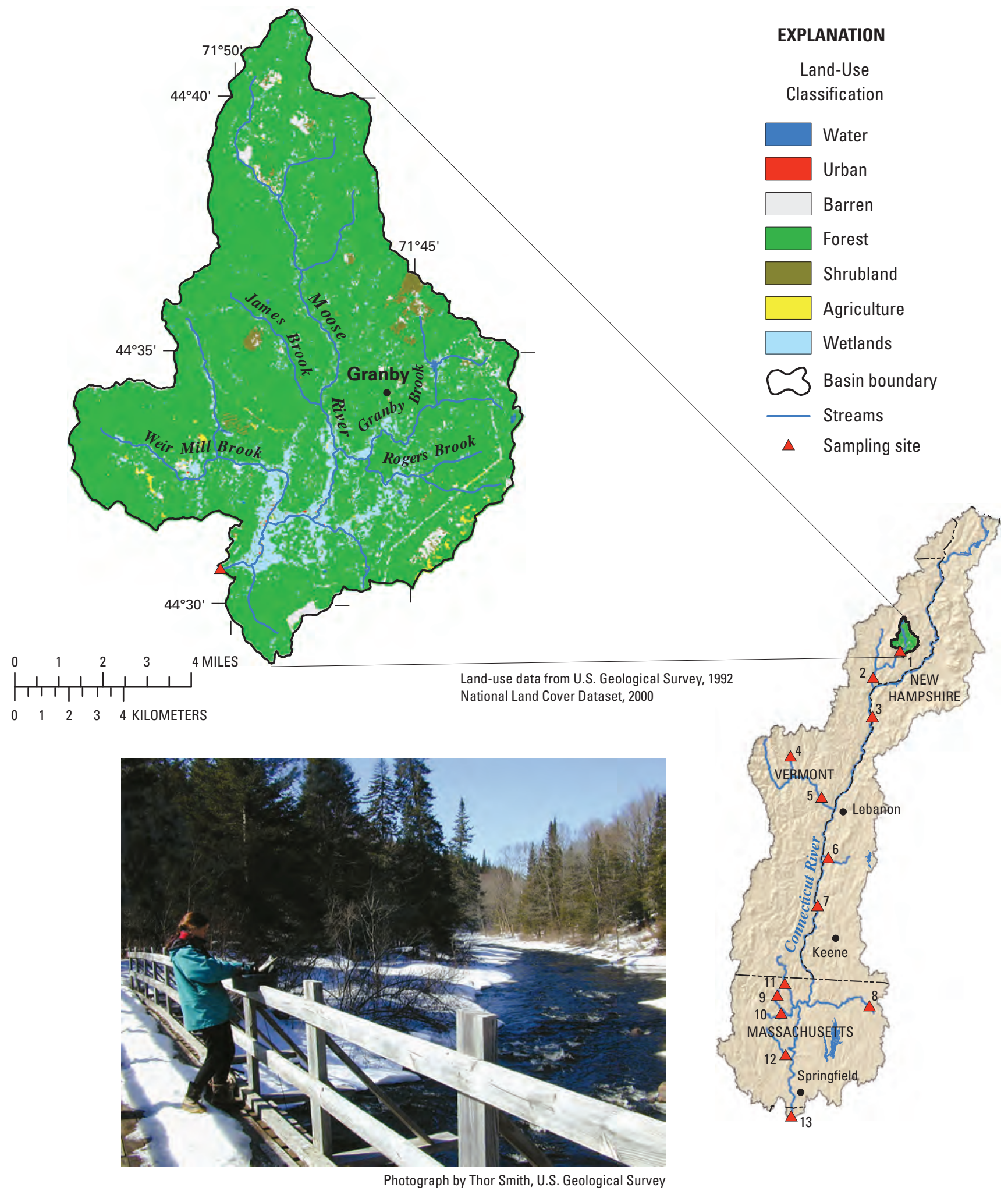

Figure 2. Location, land-use classification, and photograph of sampling site for Moose River at Victory, VT, station 01134500. (Refer to table 1 and figure 1 for additional site information.) 

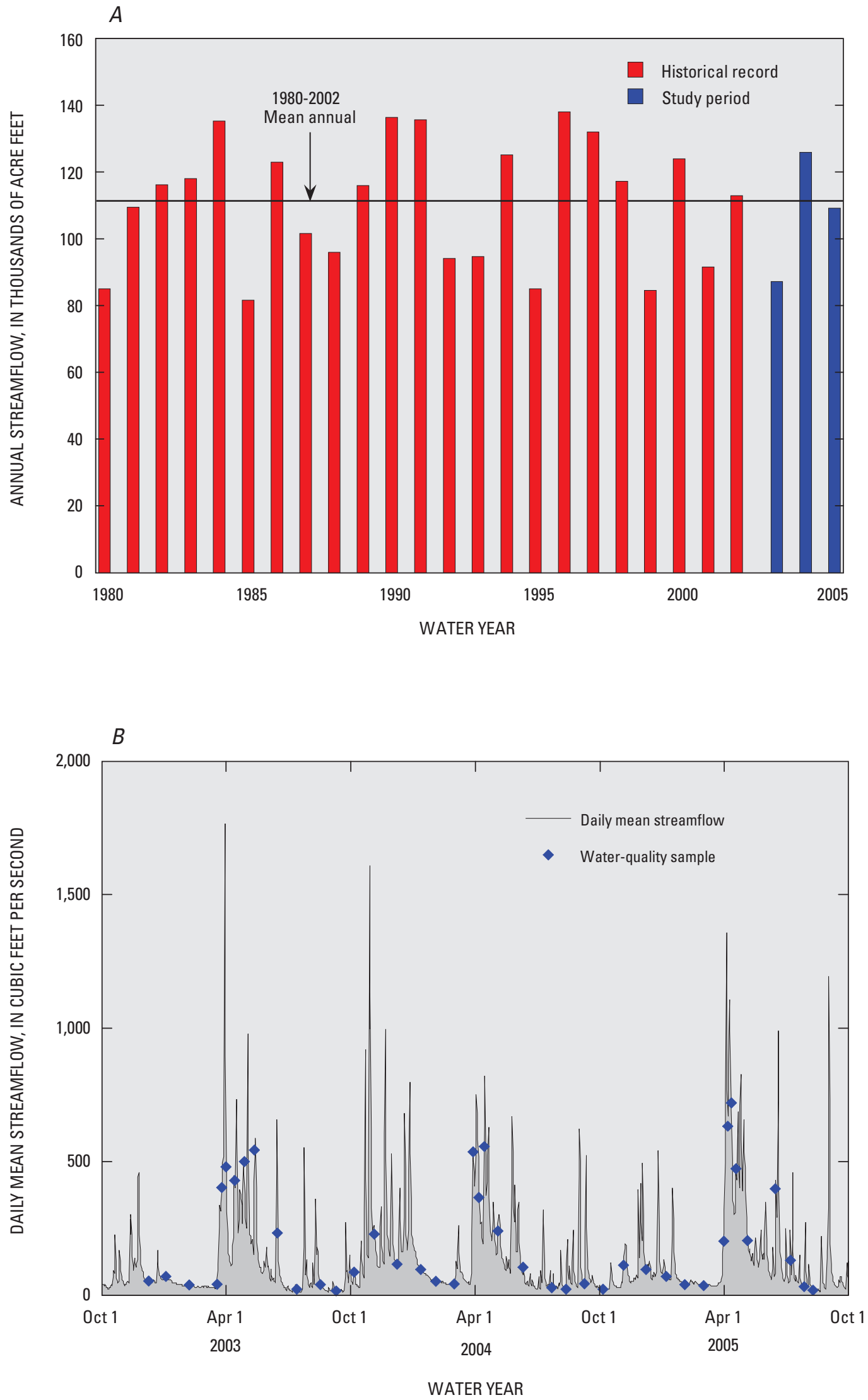

Figure 3. $A$, Historical and study-period annual streamflow, and $B$, Daily mean streamflow and time distribution of water-quality samples for Moose River at Victory, VT, station 01134500. 

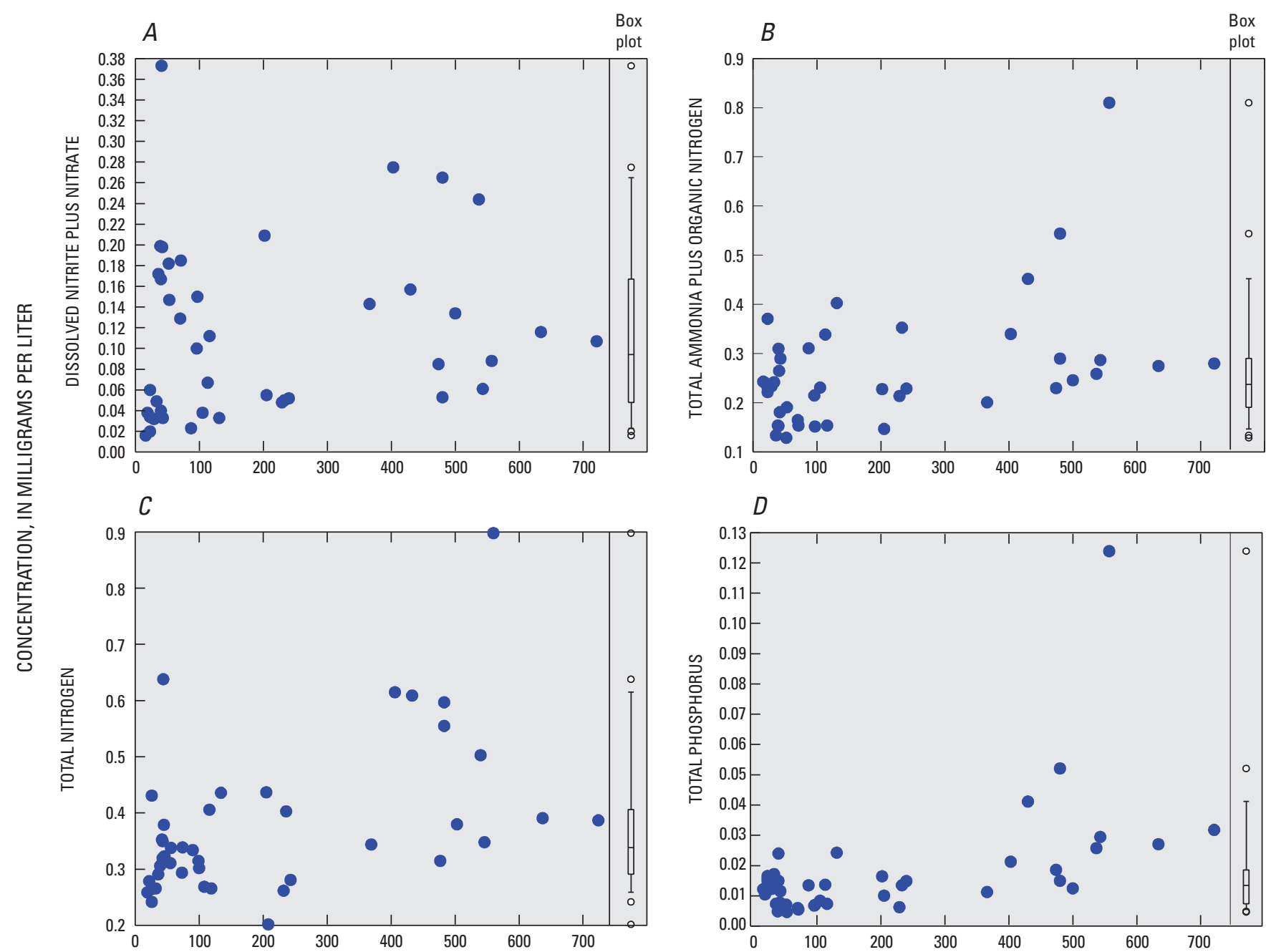

INSTANTANEOUS STREAMFLOW, IN CUBIC FEET PER SECOND
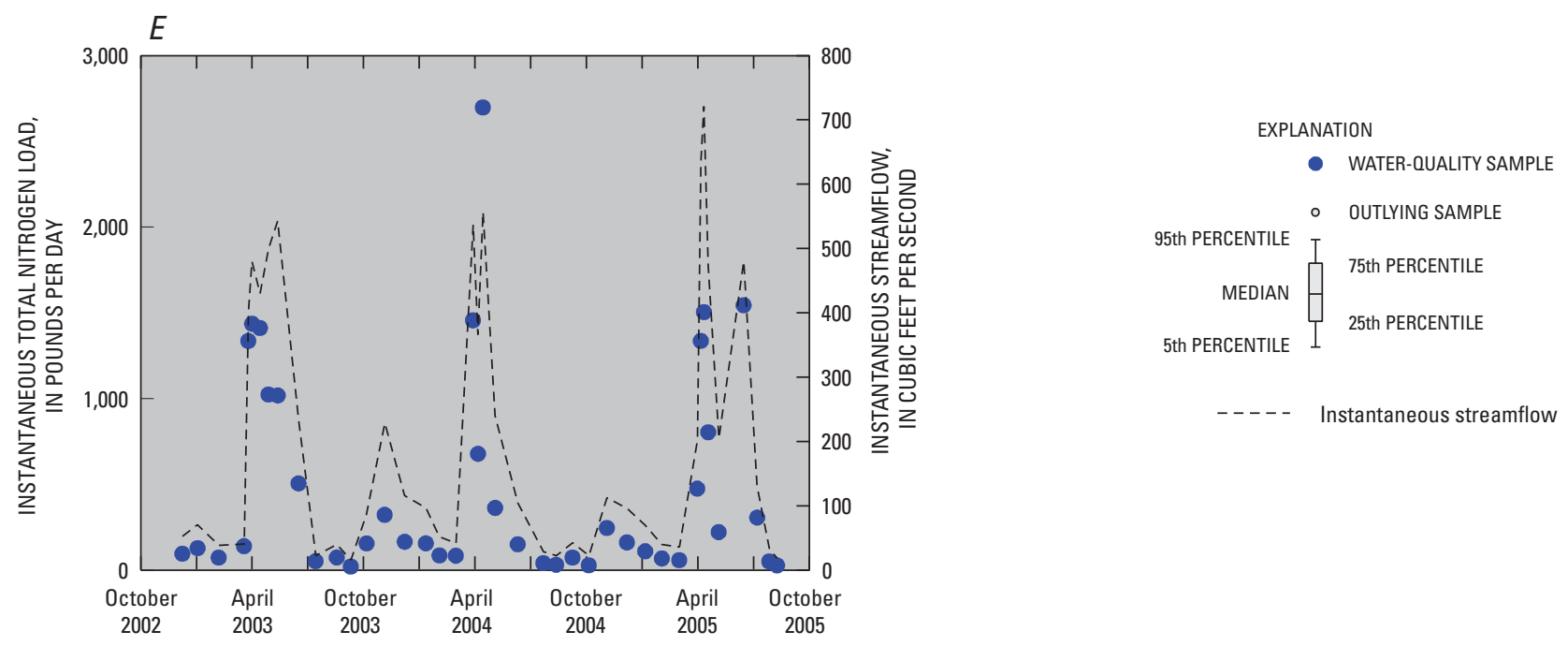

Figure 4. Distribution of $A$, Dissolved nitrite plus nitrate, $B$, Total ammonia plus organic nitrogen, $C$, Total nitrogen, $D$, Total phosphorus concentrations relative to streamflow, and $E$, Instantaneous total nitrogen load relative to time for Moose River at Victory, VT, station 01134500. (Refer to table 1 and figure 1 for station location.) 

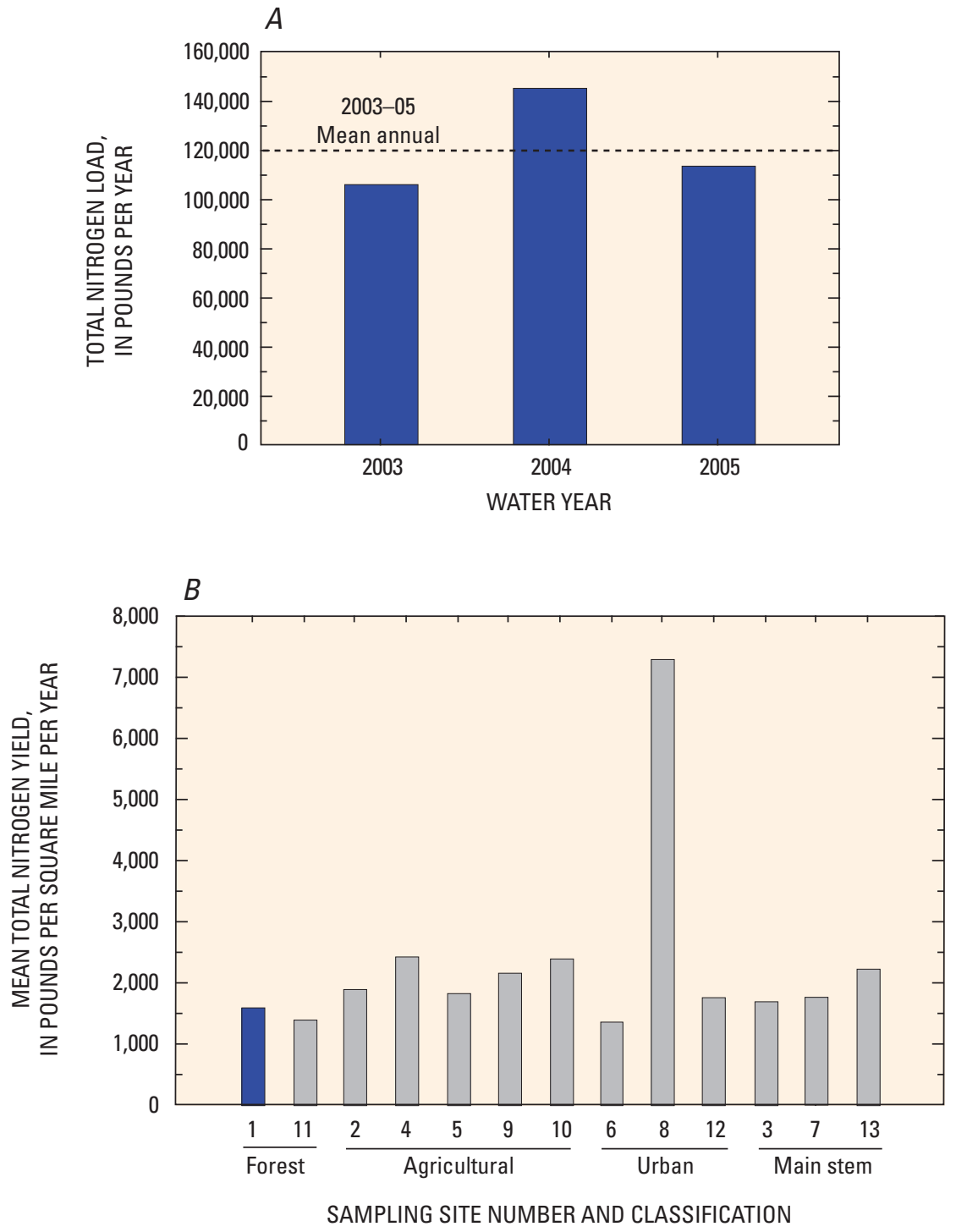

\section{EXPLANATION}

Moose River at Victory, VT

All other river sampling sites

Figure 5. A, Total nitrogen load, by year, and $B$, Mean annual total nitrogen yield (2003-05) for Moose River near Victory, VT, station 01134500 , in relation to all other river sampling sites. (Refer to table 1 and figure 1 for site names and locations.) 


\section{Passumpsic River at Passumpsic, VT, Station 01135500}

Passumpsic River at Passumpsic, VT, is classified as an agricultural site in the study area and represents potential effects on water quality from agricultural land use. The contributing drainage basin upstream from the site encompasses $436 \mathrm{mi}^{2}$ and is about 80 percent forested, 11 percent agriculture, 2 percent urban, and about 7 percent wetlands and barren (fig. 6). Annual streamflow for 1980-2002 averaged 572,000 acre-feet, with considerable year-to-year variation (fig. 7A). Annual streamflow for the data-collection period for water years 2003-05 averaged 554,000 acre-feet (table 1). Streamflow was less than the long-term mean for the first year of the study, greater than the long-term mean for the second year, and slightly less than the long-term mean for the third year (fig. 7A).

Daily mean streamflow and time distribution for 43 water-quality samples are shown in figure 7B. The minimum streamflow at which the water samples were collected was $152 \mathrm{ft}^{3} / \mathrm{s}$, and the maximum streamflow at which samples were collected was $3,820 \mathrm{ft}^{3} / \mathrm{s}$.

The minimum concentration of dissolved oxygen at this site $(8.0 \mathrm{mg} / \mathrm{L})$ was above the State of Vermont waterquality criterion for dissolved oxygen $(7.0 \mathrm{mg} / \mathrm{L}$; Vermont Water Resources Board, 2000). Concentrations of selected water-quality constituents were plotted relative to streamflow (fig. 8). Concentrations of dissolved nitrite plus nitrate ranged from 0.064 to $0.515 \mathrm{mg} / \mathrm{L}$, and showed no apparent relation to streamflow (fig. 8A). Total ammonia plus organic nitrogen ranged from 0.13 to $0.67 \mathrm{mg} / \mathrm{L}$ and generally showed no relation to streamflow for lower flow samples; however, concentrations increased at streamflows greater than $2,500 \mathrm{ft}^{3} / \mathrm{s}$ (fig. 8B). One exception was the maximum concentration of total ammonia plus organic nitrogen $(0.67 \mathrm{mg} / \mathrm{L})$ that was in a sample collected at a streamflow of about
$1,600 \mathrm{ft}^{3} / \mathrm{s}$, when streamflow was rising as a result of snowmelt (fig. 8B). Concentrations of total nitrogen ranged from 0.25 to $1.2 \mathrm{mg} / \mathrm{L}$ (fig. 8C). Concentrations of total phosphorus ranged from 0.008 to $0.155 \mathrm{mg} / \mathrm{L}$ and increased with an increase in streamflow (fig. 8D). Instantaneous loads of total nitrogen ranged from 210 to $23,800 \mathrm{lb} / \mathrm{d}$ (fig. $8 \mathrm{E}$ ). Ranges of concentrations or values for water-quality constituents not shown in figure 8 are listed below.

\begin{tabular}{lcccc}
\hline \multirow{2}{*}{$\begin{array}{l}\text { Water-quality } \\
\text { constituent }\end{array}$} & \multicolumn{4}{c}{$<$, less than; - not calculated } \\
\cline { 2 - 5 } & $\begin{array}{c}\text { Mini- } \\
\text { mum }\end{array}$ & Mean & Median & $\begin{array}{c}\text { Maxi- } \\
\text { mum }\end{array}$ \\
\hline Specific conductance & 74 & 182 & 197 & 302 \\
$\mathrm{pH}$ & 6.3 & 7.7 & 7.6 & 9.0 \\
Water temperature & .0 & 9.1 & 6.2 & 24.4 \\
Dissolved oxygen & 8.0 & 11.3 & 11.9 & 14.5 \\
Dissolved nitrite & $<.008$ & - & $<.008$ & $<.008$ \\
Dissolved ammonia & .005 & .032 & .019 & .208 \\
Dissolved orthophos- & $<.01$ & - & $<.01$ & .02 \\
$\quad$ phate (WY 2003-04) & & & & .022 \\
Dissolved orthophos- & $<.003$ & - & .005 & .022 \\
$\quad$ phate (WY 2005) & & 24 & 4 & 358 \\
Suspended sediment & 1 & 24 & \\
\hline
\end{tabular}

${ }^{a}$ All constituents are reported as milligrams per liter except for specific conductance, which is reported as microsiemens per centimeter at 25 degrees Celsius; $\mathrm{pH}$, which is reported as standard units; and water temperature, which is reported as degrees Celsius; WY, water year.

The estimated load of total nitrogen varied among years during the study (appendix A-1; fig. 9A). The mean annual total nitrogen load was $822,000 \mathrm{lb} / \mathrm{yr}$, with a ratio of the standard error of prediction to the mean load of 4.2 percent (table 2, fig. 9A). An estimated 48 percent of the total nitrogen load was transported during the spring (appendix A-2). The mean yield of total nitrogen was $1,890\left(\mathrm{lb} / \mathrm{mi}^{2}\right) / \mathrm{yr}$ (fig. 9B). 


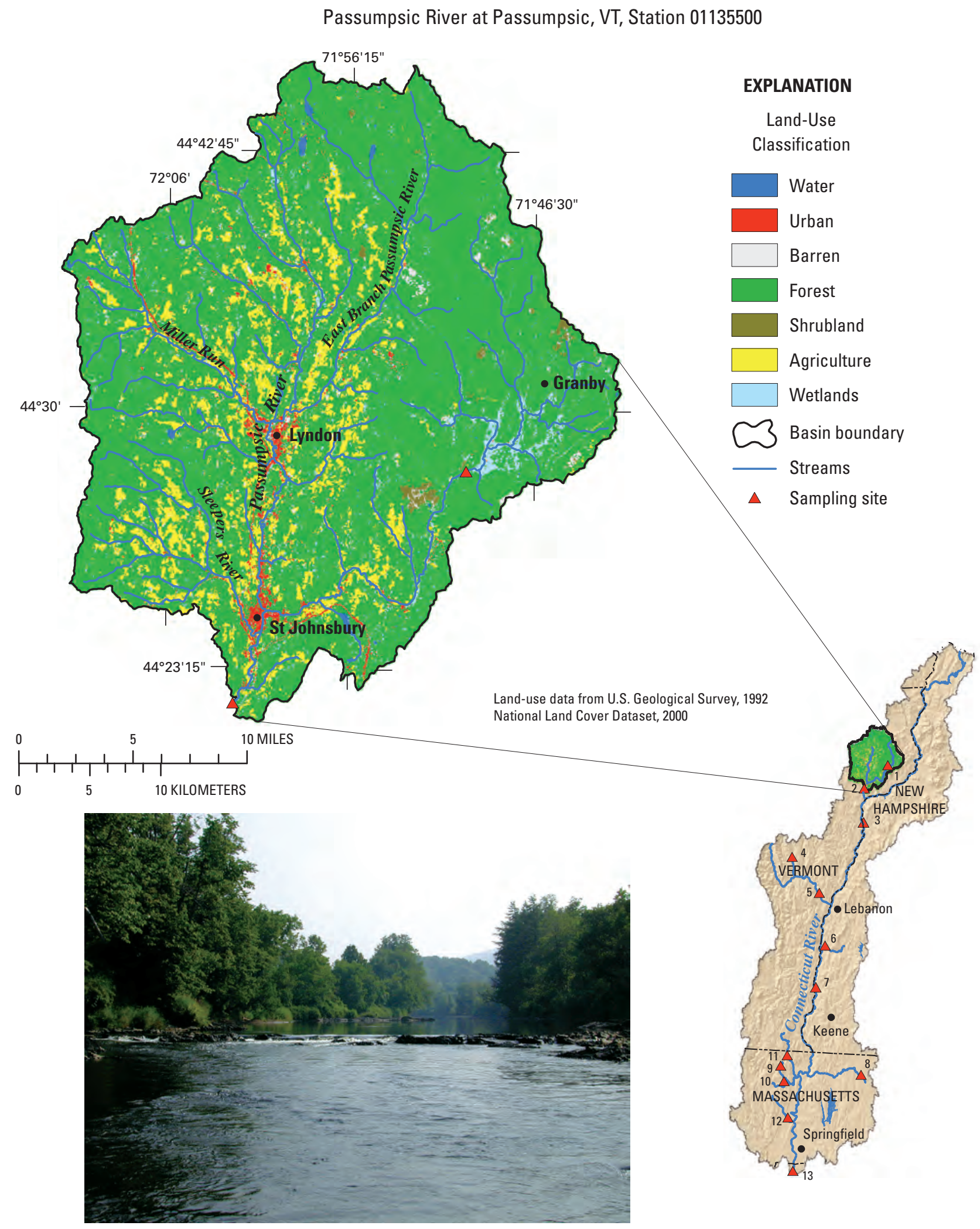

Photograph by Thor Smith, U.S. Geological Survey

Figure 6. Location, land-use classification, and photograph of sampling site for Passumpsic River at Passumpsic, VT, station 01135500. (Refer to table 1 and figure 1 for additional site information.) 

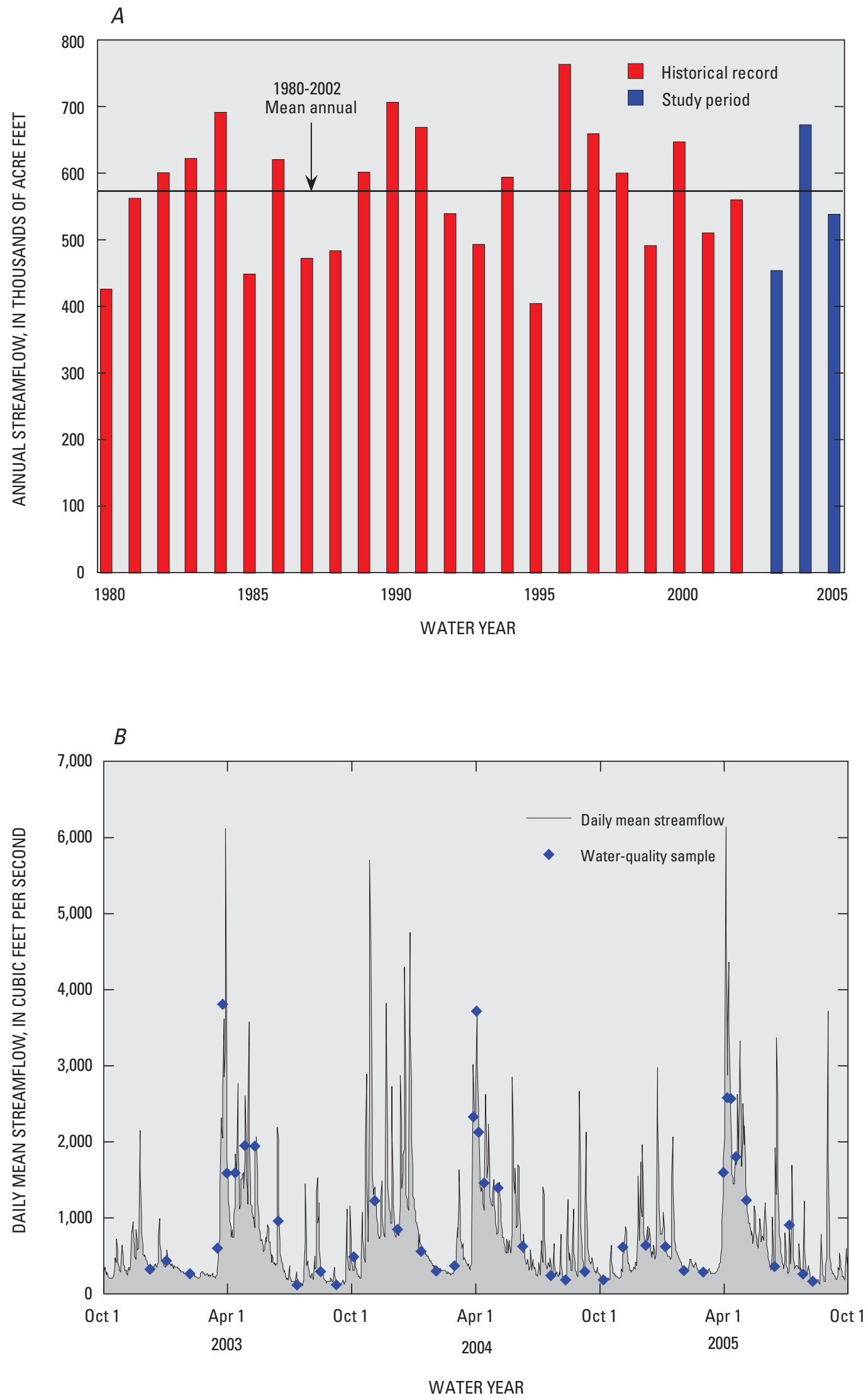

Figure 7. A, Historical and study-period annual streamflow, and $B$, Daily mean streamflow and time distribution of water-quality samples for Passumpsic River at Passumpsic, VT, station 01135500. 

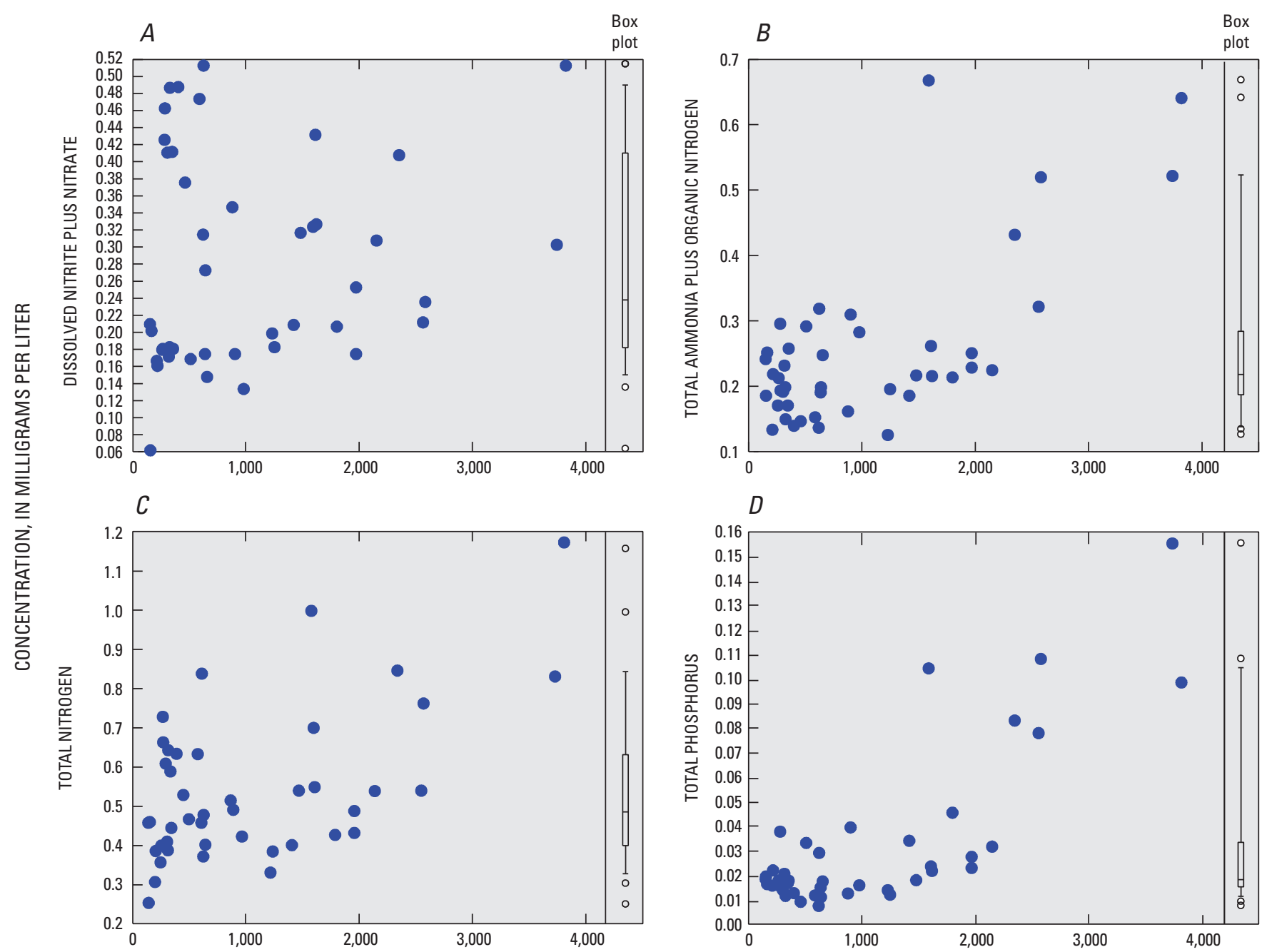

INSTANTANEOUS STREAMFLOW, IN CUBIC FEET PER SECOND
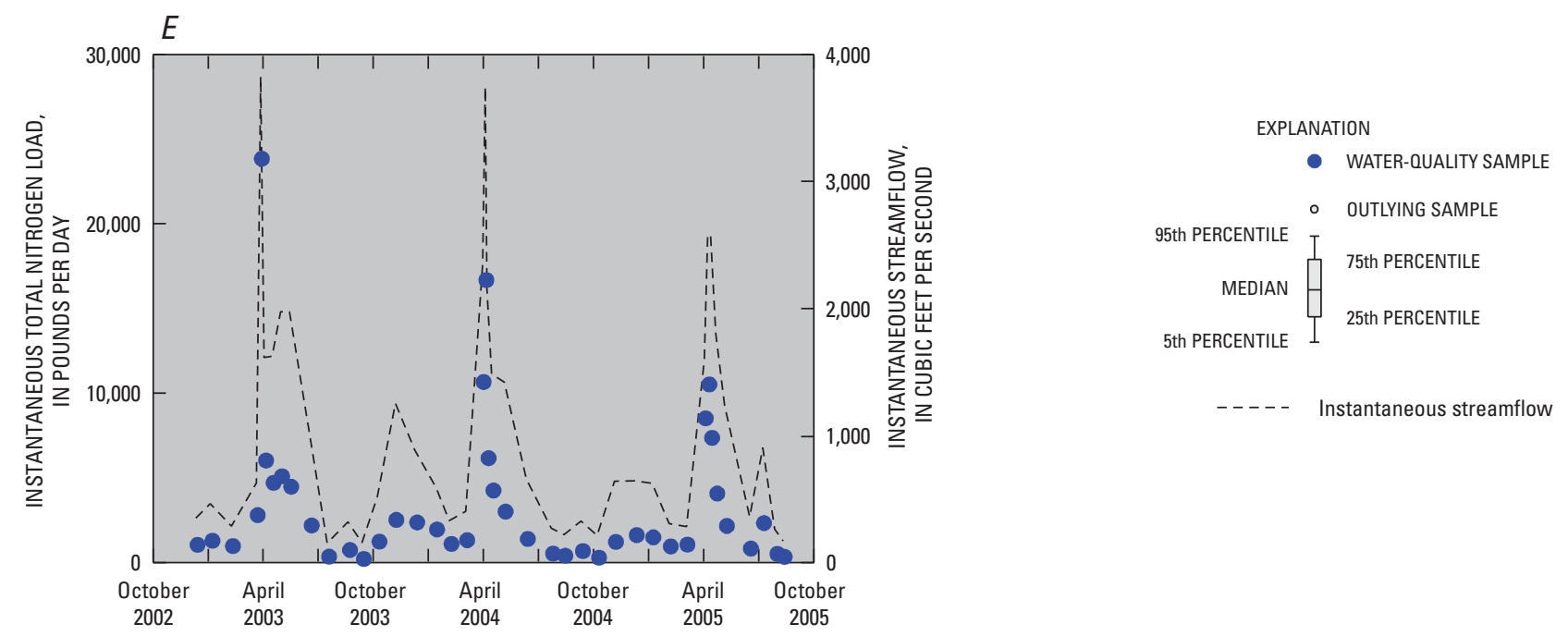

Figure 8. Distribution of $A$, Dissolved nitrite plus nitrate, $B$, Total ammonia plus organic nitrogen, $C$, Total nitrogen, $D$, Total phosphorus concentrations relative to streamflow, and $E$, Instantaneous total nitrogen load relative to time for Passumpsic River at Passumpsic, VT, station 01135500. (Refer to table 1 and figure 1 for station location.) 

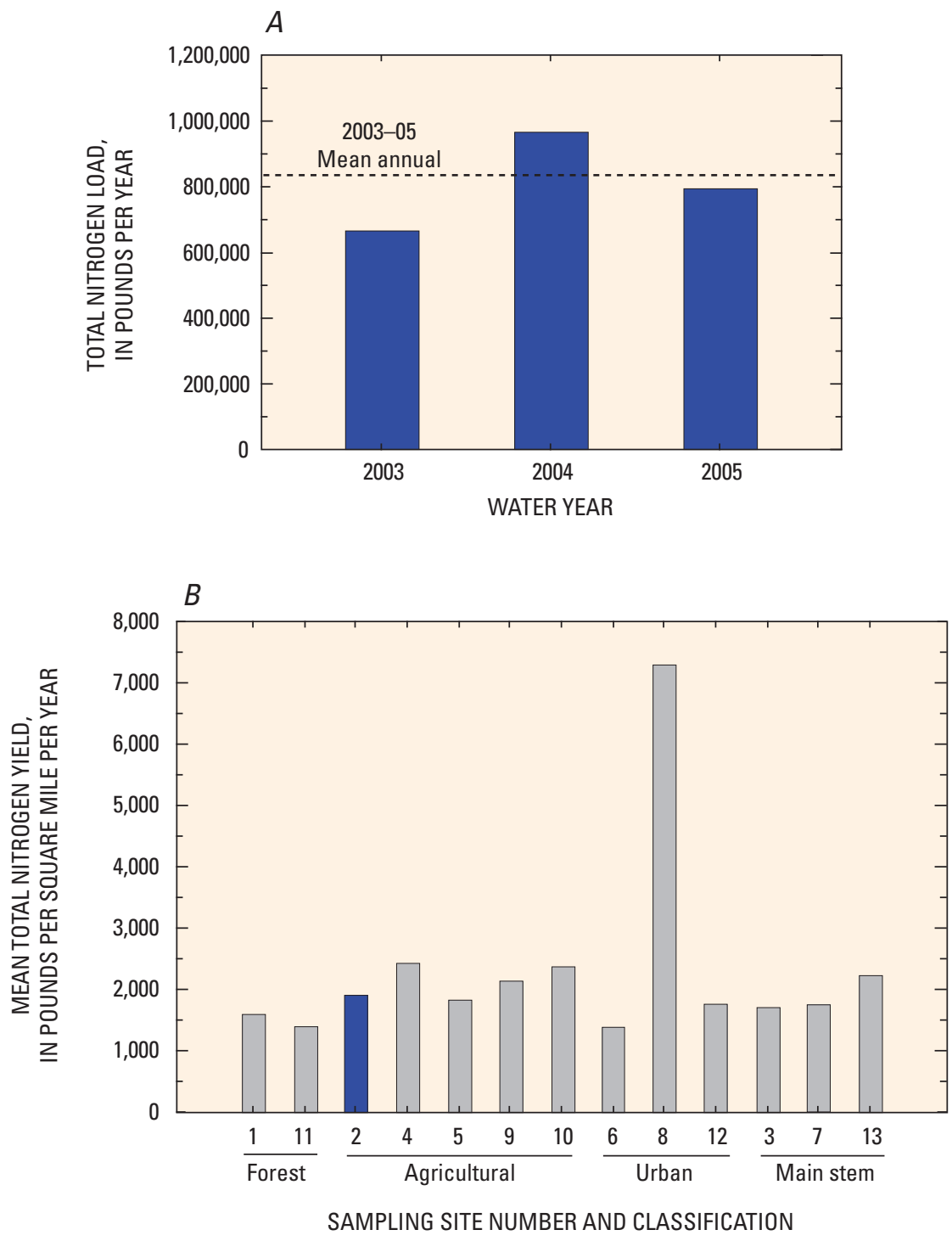

\section{EXPLANATION}

Passumpsic River at Passumpsic, VT

All other river sampling sites

Figure 9. $\quad A$, Total nitrogen load, by year, and $B$, Mean annual total nitrogen yield (2003-05) for Passumpsic River at Passumpsic, VT, station 01135500, in relation to all other river sampling sites. (Refer to table 1 and figure 1 for site names and locations.) 


\section{Connecticut River at Wells River, VT, Station 01138500}

Connecticut River at Wells River, VT, represents a main stem site in the study area and is located on the Connecticut River where there are potential effects on water quality from a mix of land uses. The contributing drainage basin upstream from this site encompasses $2,644 \mathrm{mi}^{2}$ and is about 84 percent forested, 6 percent agriculture, 2 percent urban, and 8 percent wetlands and barren (fig. 10). Annual streamflow for 19802002 averaged 3,750,000 acre-feet, with considerable yearto-year variation (fig. 11A). Annual streamflow for the datacollection period for water years 2003-05 averaged $3,560,000$ acre-feet (table 1). Streamflow was less than the long-term mean for the first year of the study, greater than the long-term mean for the second year, and slightly less than the long-term mean for the third year (fig. 11A).

Daily mean streamflow and the time distribution for 43 water-quality samples are shown in figure 11B. The minimum streamflow at which water samples were collected was $1,310 \mathrm{ft}^{3} / \mathrm{s}$, and the maximum streamflow at which samples were collected was $22,600 \mathrm{ft}^{3} / \mathrm{s}$.

The minimum concentration of dissolved oxygen at this site $(7.6 \mathrm{mg} / \mathrm{L})$ was above the State of Vermont waterquality criterion for dissolved oxygen $(7.0 \mathrm{mg} / \mathrm{L}$; Vermont Water Resources Board, 2000). Concentrations of selected water-quality constituents were plotted relative to streamflow (fig. 12). Concentrations of dissolved nitrite plus nitrate ranged from 0.110 to $0.370 \mathrm{mg} / \mathrm{L}$ and showed scatter or a poorly defined relation to streamflow (fig. 12A). Total ammonia plus organic nitrogen ranged from 0.15 to $0.46 \mathrm{mg} / \mathrm{L}$ and generally showed an increase with an increase in streamflow (fig. 12B). However, a sample that was collected at a streamflow of about $4,500 \mathrm{ft}^{3} / \mathrm{s}$ during snowmelt had the second highest concentration of total ammonia plus organic nitrogen $(0.40 \mathrm{mg} / \mathrm{L}$; fig. $12 \mathrm{~B})$. Concentrations of total nitrogen ranged from 0.30 to $0.74 \mathrm{mg} / \mathrm{L}$ (fig. 12C). Concentrations of total phosphorus ranged from 0.007 to $0.112 \mathrm{mg} / \mathrm{L}$ and generally showed some scatter but also a slight increase with an increase in streamflow (fig. 12D). The sample that was collected at about $4,500 \mathrm{ft}^{3} / \mathrm{s}$ when streamflow was rising during snowmelt also had the second highest concentration of total phosphorus $(0.110 \mathrm{mg} / \mathrm{L}$; fig. 12D). Instantaneous loads of total nitrogen ranged from 2,300 to 71,900 lb/d (fig. 12E). Ranges of concentrations or values for water-quality constituents not shown in figure 12 are listed below.

\begin{tabular}{|c|c|c|c|c|}
\hline \multirow{2}{*}{$\begin{array}{l}\text { Water-quality } \\
\text { constituent }^{\mathrm{a}}\end{array}$} & \multicolumn{4}{|c|}{$<$, less than; - , not calculated } \\
\hline & $\begin{array}{c}\text { Mini- } \\
\text { mum }\end{array}$ & Mean & Median & $\begin{array}{c}\text { Maxi- } \\
\text { mum }\end{array}$ \\
\hline Specific conductance & 58 & 87 & 87 & 119 \\
\hline $\mathrm{pH}$ & 6.4 & 7.1 & 7.1 & 7.7 \\
\hline Water temperature & .0 & 8.3 & 5.5 & 23.2 \\
\hline Dissolved oxygen & 7.6 & 11.3 & 11.6 & 15.2 \\
\hline Dissolved nitrite & $<.004$ & - & $<.004$ & .005 \\
\hline Dissolved ammonia & .007 & .021 & .017 & .080 \\
\hline $\begin{array}{l}\text { Dissolved orthophos- } \\
\text { phate (WY 2003-04) }\end{array}$ & $<.01$ & - & $<.01$ & $<.01$ \\
\hline $\begin{array}{l}\text { Dissolved orthophos- } \\
\text { phate (WY 2005) }\end{array}$ & $<.003$ & - & $<.003$ & .006 \\
\hline Suspended sediment & 1 & 24 & 5 & 337 \\
\hline
\end{tabular}

${ }^{a}$ All constituents are reported as milligrams per liter except for specific conductance, which is reported as microsiemens per centimeter at 25 degrees Celsius; $\mathrm{pH}$, which is reported as standard units; and water temperature, which is reported as degrees Celsius; WY, water year.

The estimated load of total nitrogen varied among years during the study (appendix A-1; fig. 13A). The mean annual load of total nitrogen was 4,470,000 lb/yr, with a ratio of the standard error of prediction to the mean load of 2.2 percent (table 2, fig. 13A). An estimated 45 percent of the total nitrogen load was transported during the spring (appendix A-2). The mean yield of total nitrogen $\left(1,690\left(\mathrm{lb} / \mathrm{mi}^{2}\right) / \mathrm{yr}\right)$ was similar to the yield of total nitrogen at Connecticut River at North Walpole, NH (site 7), but less than the yield of total nitrogen at the Connecticut River at Thompsonville, CT (site 13), the site representing the outlet to the upper basin (fig. 13B). 
Connecticut River at Wells River, VT, Station 01138500

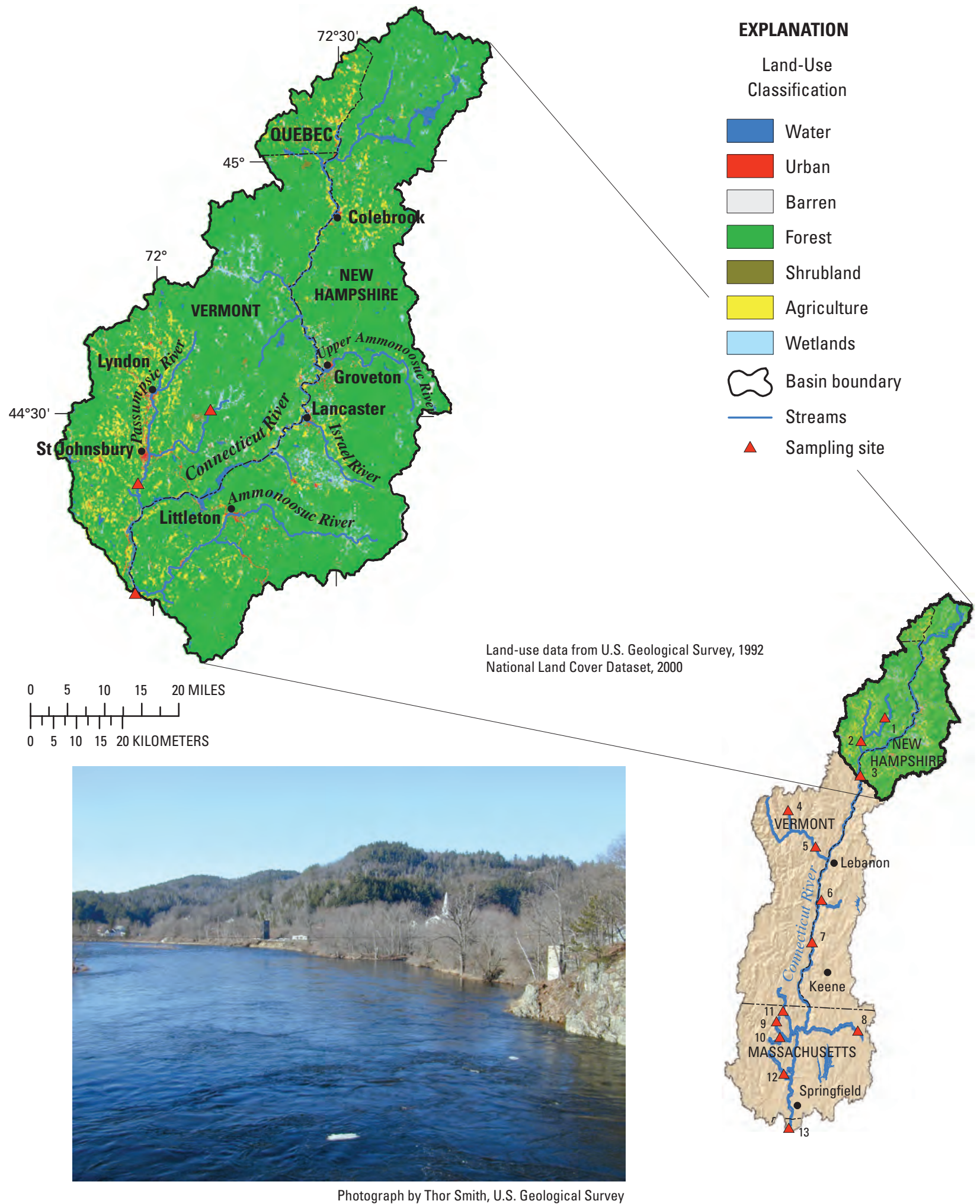

Figure 10. Location, land-use classification, and photograph of sampling site for Connecticut River at Wells River, VT, station 01138500 . (Refer to table 1 and figure 1 for additional site information.) 

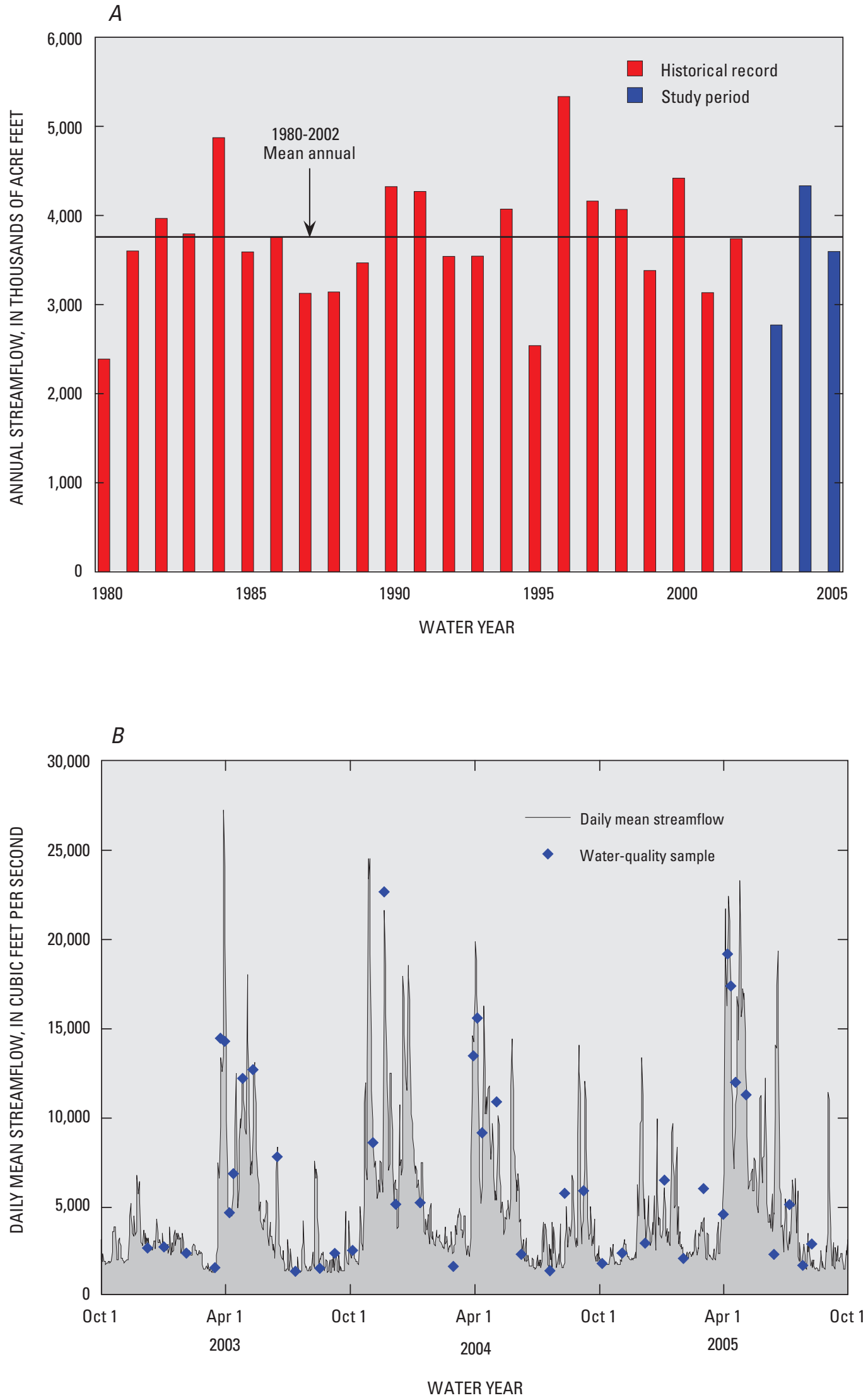

Figure 11. A, Historical and study-period annual streamflow, and $B$, Daily mean streamflow and time distribution of water-quality samples for Connecticut River at Wells River, VT, station 01138500. 

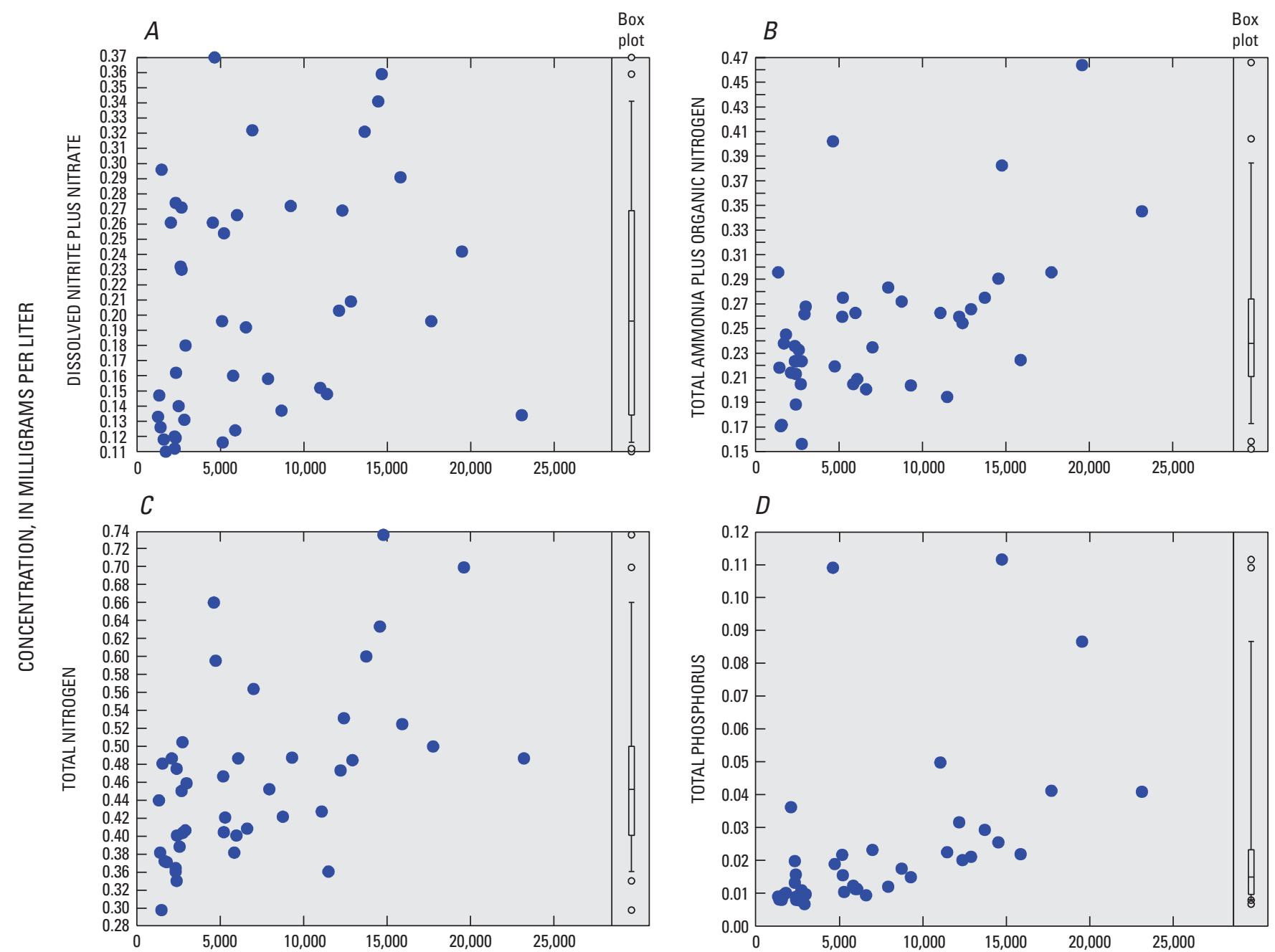

INSTANTANEOUS STREAMFLOW, IN CUBIC FEET PER SECOND
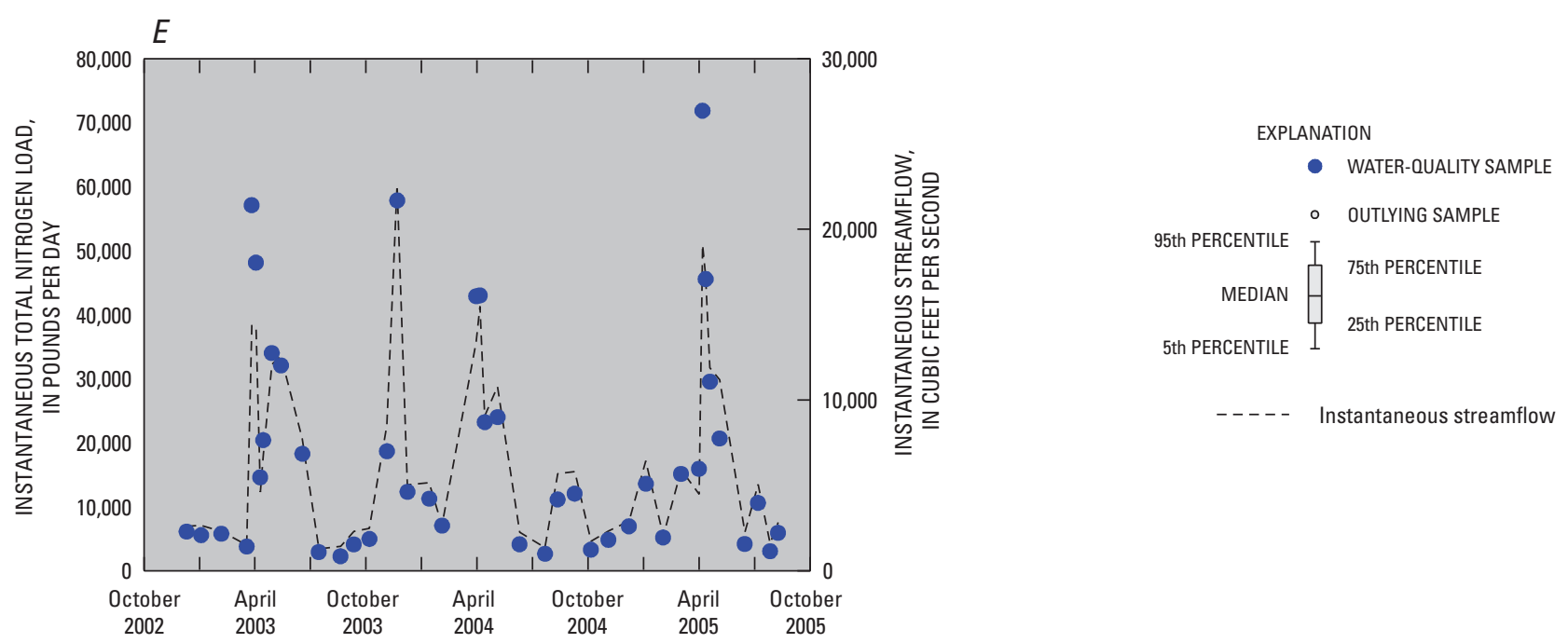

Figure 12. Distribution of $A$, Dissolved nitrite plus nitrate, $B$, Total ammonia plus organic nitrogen, $C$, Total nitrogen, $D$, Total phosphorus concentrations relative to streamflow, and $E$, Instantaneous total nitrogen load relative to time for Connecticut River at Wells River, VT, station 01138500. (Refer to table 1 and figure 1 for station location.) 

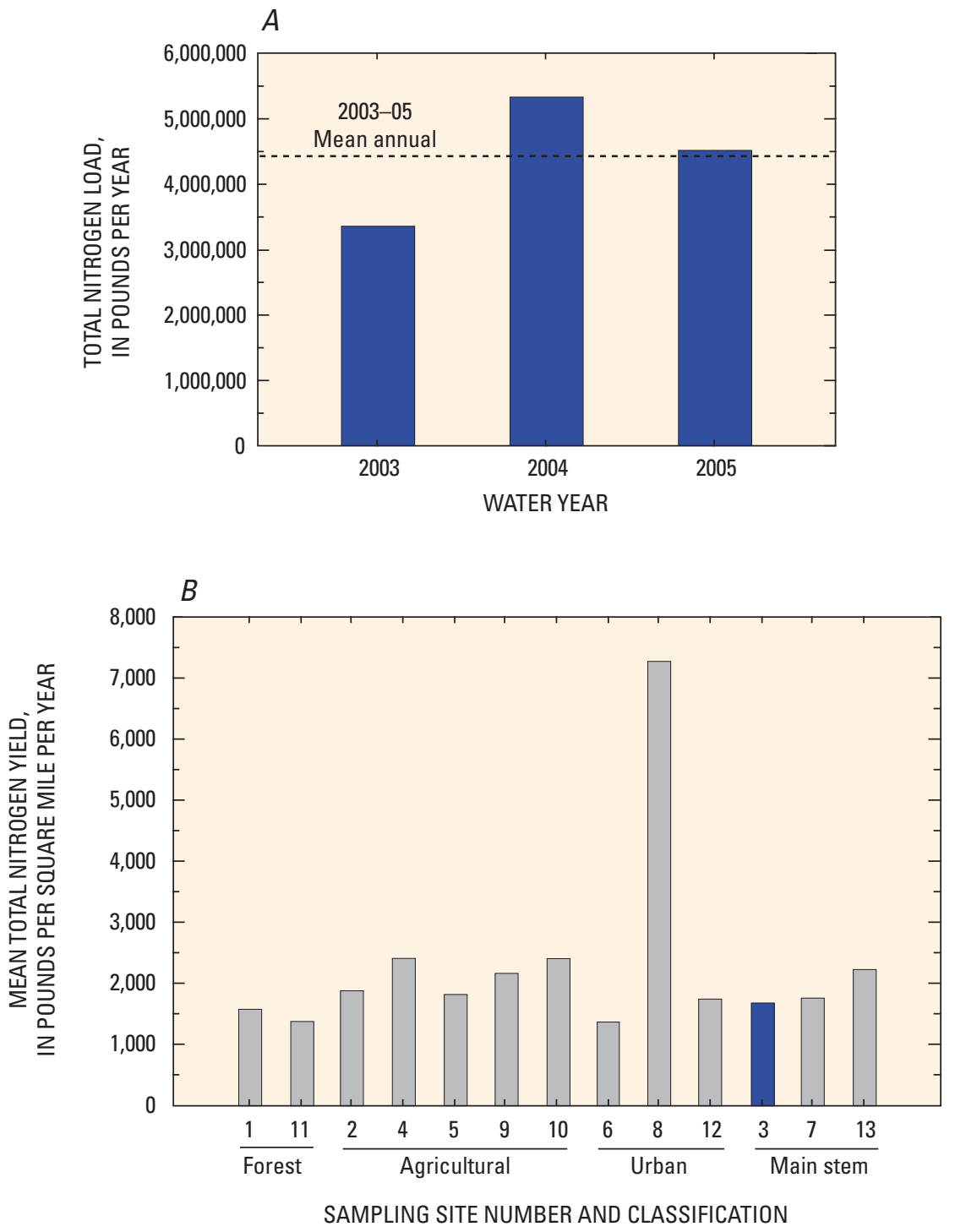

EXPLANATION

Connecticut River at Wells River, VT

All other river sampling sites

Figure 13. A, Total nitrogen load, by year, and $B$, Mean annual total nitrogen yield (2003-05) for Connecticut River at Wells River, VT, station 01138500 , in relation to all other river sampling sites. (Refer to table 1 and figure 1 for site names and locations.) 


\section{Ayers Brook at Randolph, VT, Station 01142500}

Ayers Brook at Randolph, VT, represents an agricultural site in the study area. The contributing drainage basin upstream from the site encompasses $31 \mathrm{mi}^{2}$ and is about 73 percent forested, 21 percent agriculture, 1 percent urban, and 5 percent wetlands and barren (fig. 14). Annual streamflow for 1980-2002 averaged 37,300 acre-feet, with considerable year-to-year variation (fig. 15A). Annual streamflow for the data-collection period for water years 2003-05 averaged 38,200 acre-feet (table 1). Streamflow was less than the long-term mean for the first year of the study, greater than the long-term mean for the second year, and slightly greater than the long-term mean for the third year (fig. 15A).

Daily mean streamflow and time distribution for 43 water-quality samples are shown in figure 15B. The minimum streamflow at which water samples were collected was $10 \mathrm{ft}^{3} / \mathrm{s}$, and the maximum streamflow at which samples were collected was $310 \mathrm{ft}^{3} / \mathrm{s}$.

The minimum concentration of dissolved oxygen at this site $(8.2 \mathrm{mg} / \mathrm{L})$ was above the State of Vermont water-quality criterion for dissolved oxygen $(7.0 \mathrm{mg} / \mathrm{L}$; Vermont Water Resources Board, 2000). Concentrations of selected waterquality constituents were plotted relative to streamflow (fig. 16). Concentrations of dissolved nitrite plus nitrate ranged from 0.291 to $0.733 \mathrm{mg} / \mathrm{L}$ and showed scatter or a poorly defined relation to streamflow (fig. 16A). Total ammonia plus organic nitrogen ranged from an estimated 0.06 to $1.3 \mathrm{mg} / \mathrm{L}$ and showed a slight variation with an increase in streamflow (fig. 16B). Concentrations of total nitrogen ranged from 0.39 to $1.8 \mathrm{mg} / \mathrm{L}$ and also showed a slight variation with streamflow (fig. 16C). Concentrations of total phosphorus ranged from an estimated concentration of 0.003 to $0.708 \mathrm{mg} / \mathrm{L}$ and increased with an increase in streamflow, especially at streamflows greater than about $100 \mathrm{ft}^{3} / \mathrm{s}$ (fig. 16D). Instantaneous loads of total nitrogen ranged from 27 to $2,760 \mathrm{lb} / \mathrm{d}$ (fig. 16E). Ranges of concentrations or values for water-quality constituents not shown in figure 16 are listed below.

\begin{tabular}{lcccc}
\hline \multirow{2}{*}{$\begin{array}{l}\text { Water-quality } \\
\text { constituent }\end{array}$} & \multicolumn{4}{c}{$<$, less than; - , not calculated } \\
\cline { 2 - 5 } & $\begin{array}{c}\text { Mini- } \\
\text { mum }\end{array}$ & Mean & Median & $\begin{array}{c}\text { Maxi- } \\
\text { mum }\end{array}$ \\
\hline Specific conductance & 127 & 210 & 209 & 293 \\
pH & 6.3 & 7.5 & 7.6 & 8.2 \\
Water temperature & .0 & 7.9 & 6.5 & 22 \\
Dissolved oxygen & 8.2 & 11.6 & 11.7 & 15.0 \\
Dissolved nitrite & $<.004$ & - & $<.004$ & .006 \\
Dissolved ammonia & .005 & .016 & .011 & .111 \\
Dissolved orthophos- & $<.01$ & - & $<.01$ & $<.01$ \\
$\quad$ phate (WY 2003-04) & & & & \\
Dissolved orthophos- & $<.003$ & - & $<.003$ & .004 \\
$\quad$ phate (WY 2005) & & & 5 & 776 \\
Suspended sediment & 1 & 73 & 5 & \\
\hline
\end{tabular}

${ }^{a}$ All constituents are reported as milligrams per liter except for specific conductance, which is reported as microsiemens per centimeter at 25 degrees Celsius; $\mathrm{pH}$, which is reported as standard units; and water temperature, which is reported as degrees Celsius; WY, water year.

The estimated load of total nitrogen varied among years during the study (appendix A-1; fig. 17A). The mean annual load of total nitrogen was $74,900 \mathrm{lb} / \mathrm{yr}$, with a ratio of the standard error of prediction to the mean load of 3.5 percent (table 2, fig. 17A). An estimated 51 percent of the load of total nitrogen was transported during the spring (appendix A-2). The mean yield of total nitrogen $\left(2,450\left(\mathrm{lb} / \mathrm{mi}^{2}\right) / \mathrm{yr}\right)$ was greater than the yield of total nitrogen at all other sites, with the exception of one urban site that was directly affected by wastewater (site 8; fig. 17B). 
Ayers Brook at Randolph, VT, Station 01142500

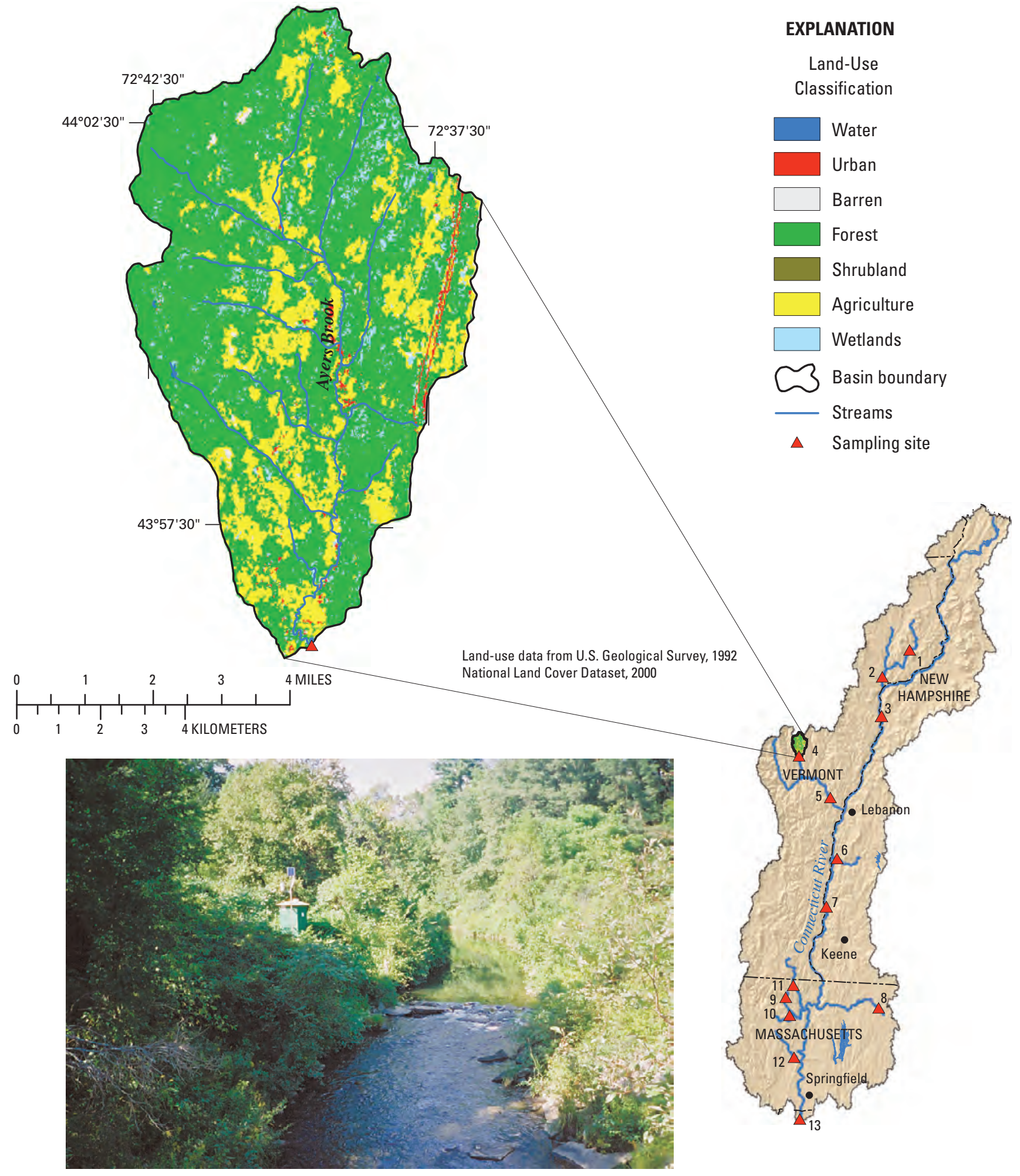

Photograph by Thor Smith, U.S. Geological Survey

Figure 14. Location, land-use classification, and photograph of sampling site for Ayers Brook at Randolph, VT, station 01142500. (Refer to table 1 and figure 1 for additional site information.) 

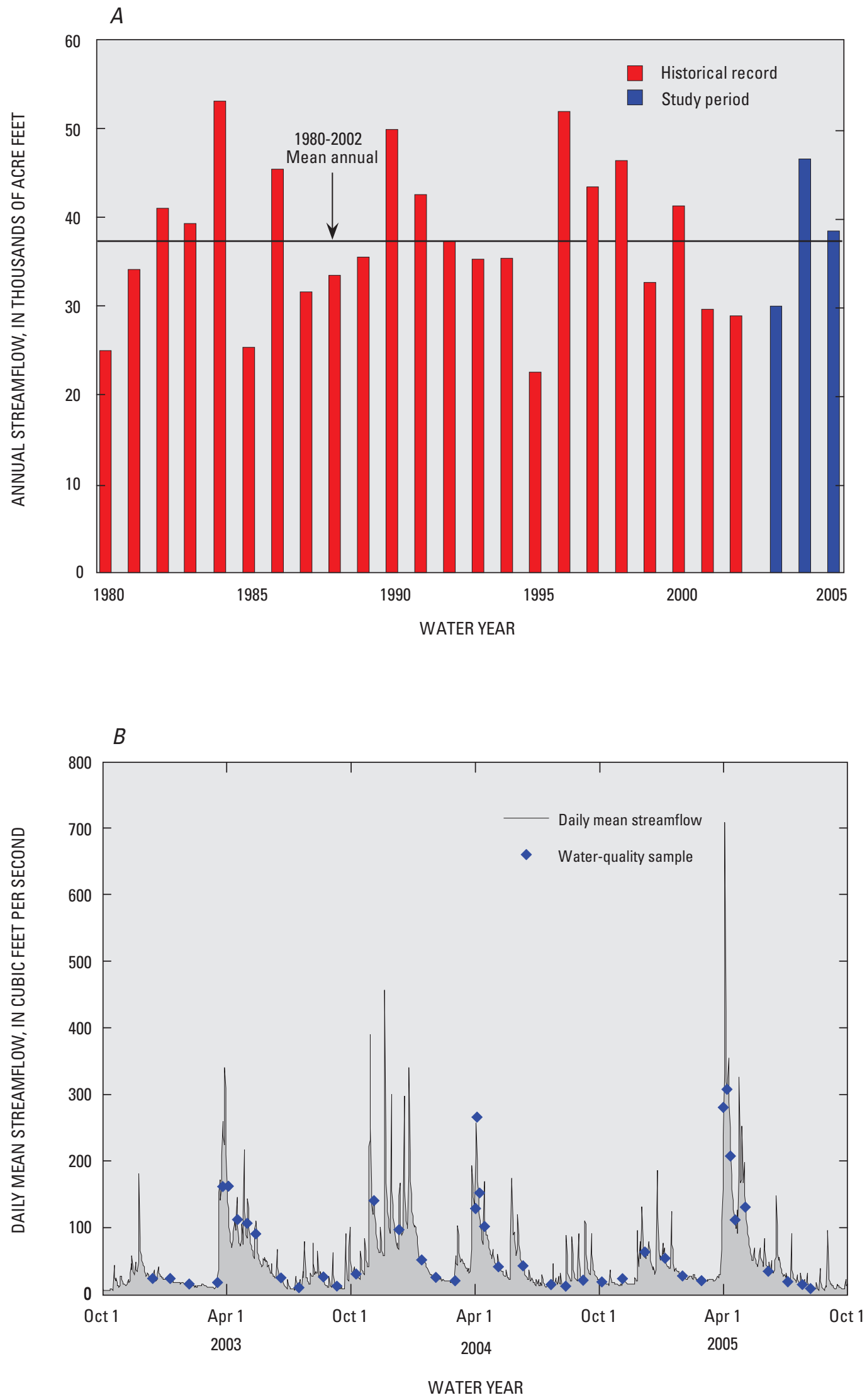

Figure 15. A, Historical and study-period annual streamflow, and $B$, Daily mean streamflow and time distribution of water-quality samples for Ayers Brook at Randolph, VT, station 01142500. 

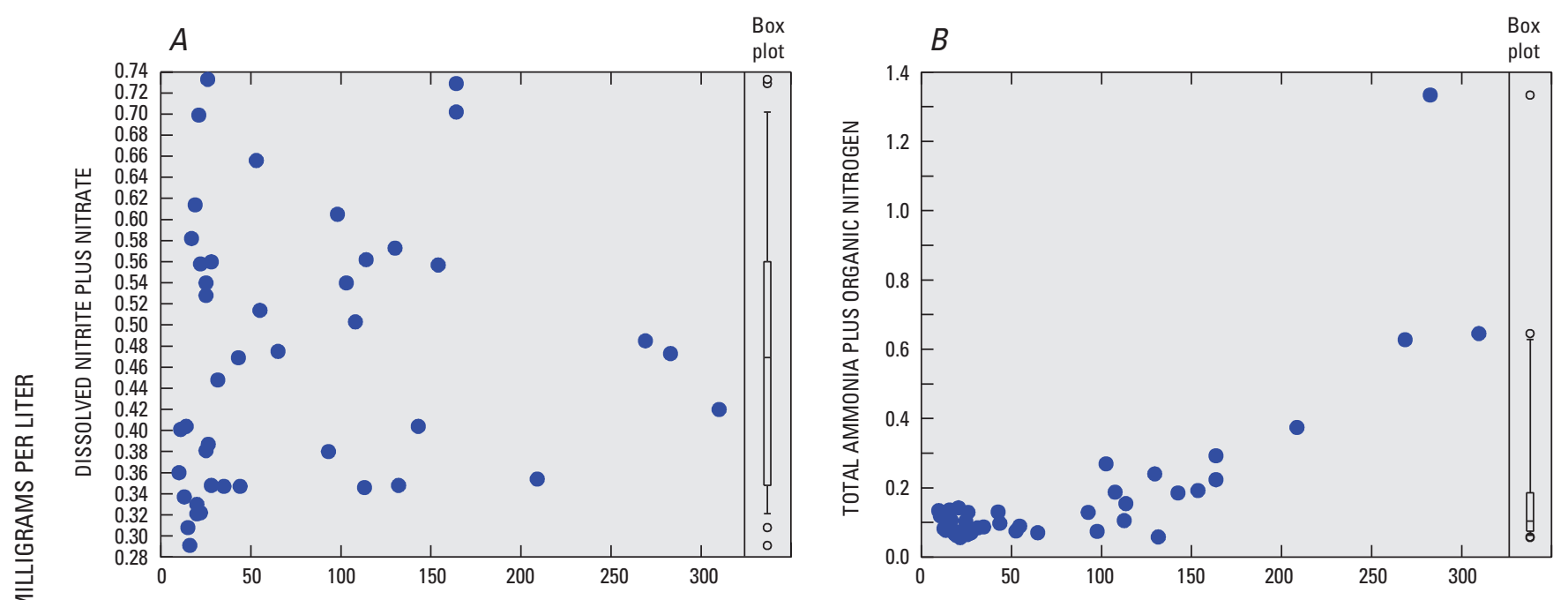

C
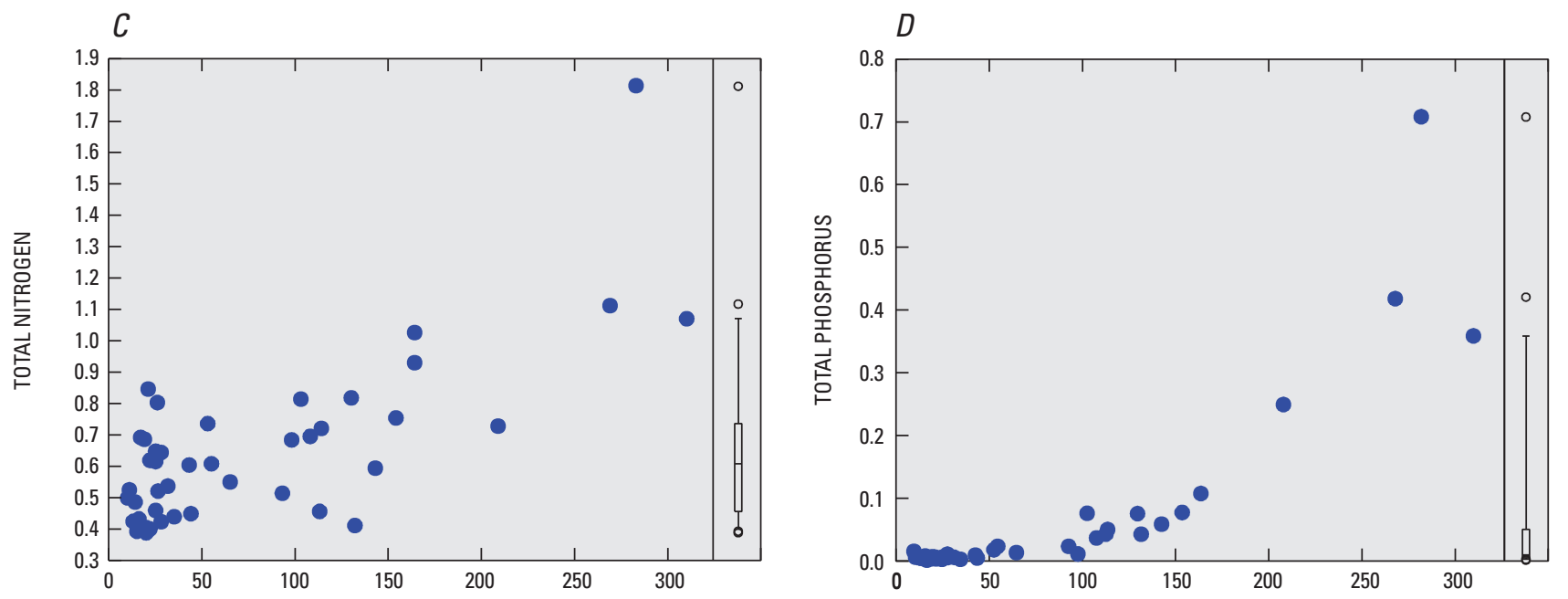

INSTANTANEOUS STREAMFLOW, IN CUBIC FEET PER SECOND
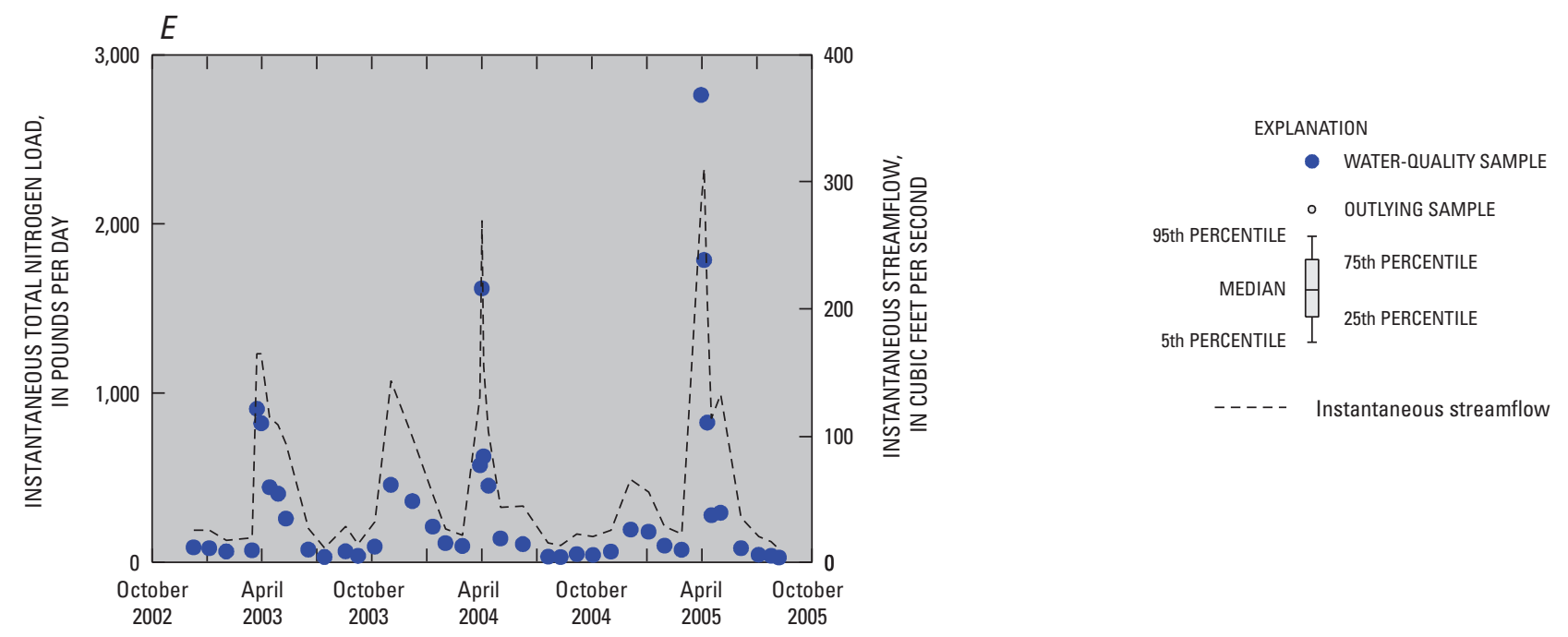

Figure 16. Distribution of $A$, Dissolved nitrite plus nitrate, $B$, Total ammonia plus organic nitrogen, $C$, Total nitrogen, $D$, Total phosphorus concentrations relative to streamflow, and $E$, Instantaneous total nitrogen load relative to time for Ayers Brook at Randolph, VT, station 01142500. (Refer to table 1 and figure 1 for station location.) 

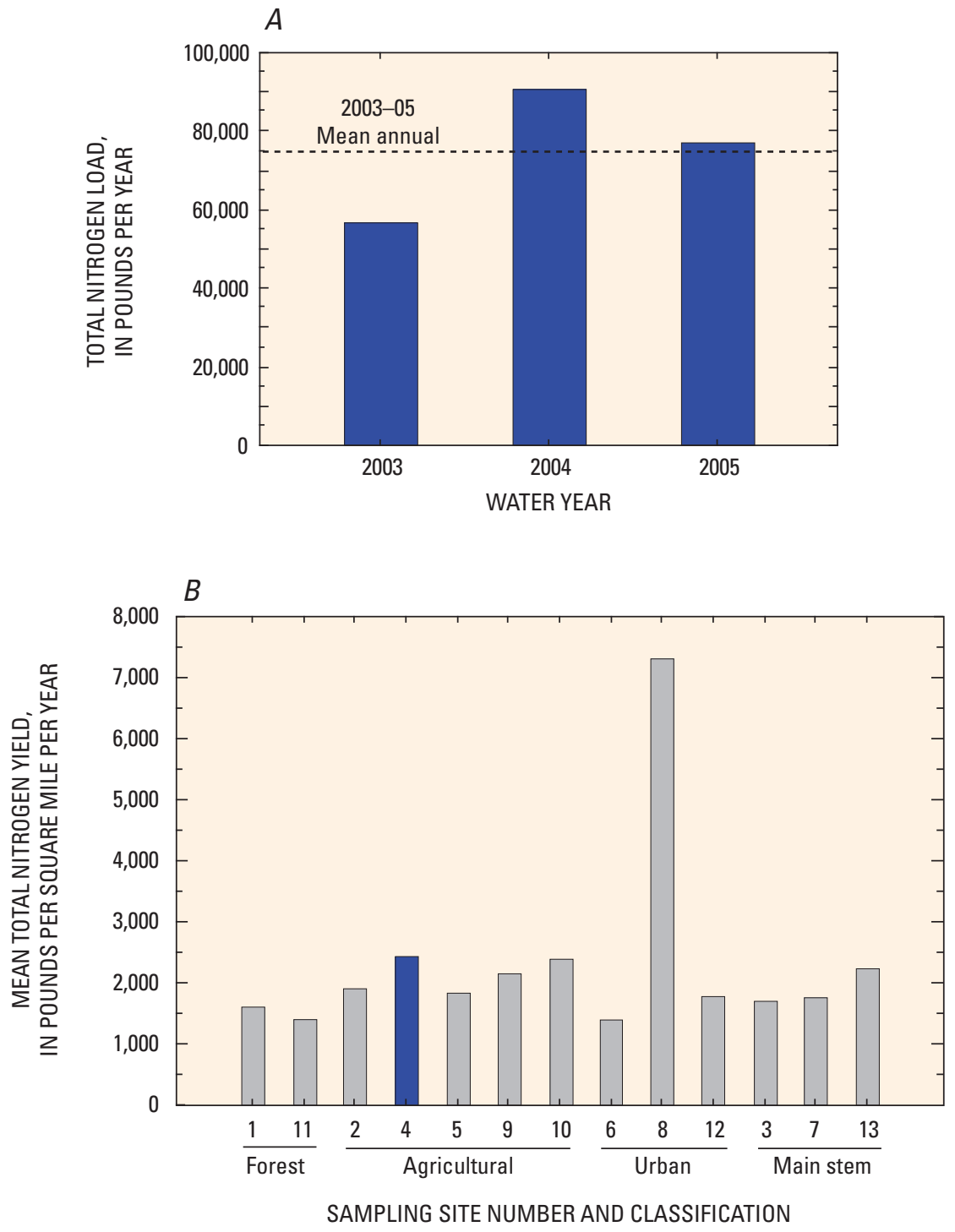

\section{EXPLANATION}

Ayers Brook at Randolph, VT

All other river sampling sites

Figure 17. A, Total nitrogen load, by year, and $B$, Mean annual total nitrogen yield (2003-05) for Ayers Brook at Randolph, VT, station 01142500, in relation to all other river sampling sites. (Refer to table 1 and figure 1 for site names and locations.) 


\section{White River at West Hartford, VT, Station 01144000}

White River at West Hartford, VT, represents an agricultural site in the study area. The contributing drainage basin upstream from this site encompasses $690 \mathrm{mi}^{2}$ and is about 84 percent forested, 13 percent agriculture, 1 percent urban, and 2 percent wetlands and barren (fig. 18). Annual streamflow for 1980-2002 averaged 885,000 acre-feet, with considerable year-to-year variation (fig. 19A). Annual streamflow for the data-collection period for water years 2003-05 averaged 959,000 acre-feet (table 1). Streamflow was less than the long-term mean for the first year of this study, greater than the long-term mean for the second year, and about equal to the long-term mean for the third year (fig. 19A).

Daily mean streamflows and time distribution for 45 water-quality samples are shown in figure 19B. The minimum streamflow at which water samples were collected was $216 \mathrm{ft}^{3} / \mathrm{s}$, and the maximum streamflow at which samples were collected was $11,600 \mathrm{ft}^{3} / \mathrm{s}$.

The minimum concentration of dissolved oxygen at this site $(8.0 \mathrm{mg} / \mathrm{L})$ was above the State of Vermont water-quality criterion for dissolved oxygen $(7.0 \mathrm{mg} / \mathrm{L}$; Vermont Water Resources Board, 2000). Concentrations of selected waterquality constituents were plotted relative to streamflow (fig. 20). Concentrations of dissolved nitrite plus nitrate ranged from 0.138 to $0.535 \mathrm{mg} / \mathrm{L}$ and showed scatter or a poorly defined relation to streamflow (fig. 20A). Total ammonia plus organic nitrogen ranged from an estimated 0.06 to $0.81 \mathrm{mg} / \mathrm{L}$ and generally increased as streamflow increased (fig. 20B). Concentrations of total nitrogen ranged from 0.24 to $1.1 \mathrm{mg} / \mathrm{L}$ and increased as streamflow increased (fig. 20C). Concentrations of total phosphorus ranged from an estimated 0.002 to $0.604 \mathrm{mg} / \mathrm{L}$ and also increased with an increase in streamflow, especially at streamflows greater than about $2,000 \mathrm{ft}^{3} / \mathrm{s}$ (fig. 20D). Instantaneous loads of total nitrogen ranged from 351 to $52,700 \mathrm{lb} / \mathrm{d}$ (fig. 20E). Ranges of concentrations or values for water-quality constituents not shown in figure 20 are listed below.

\begin{tabular}{|c|c|c|c|c|}
\hline \multirow{2}{*}{$\begin{array}{l}\text { Water-quality } \\
\text { constituent }^{\mathrm{a}}\end{array}$} & \multicolumn{4}{|c|}{$<$, less than; - , not calculated } \\
\hline & $\begin{array}{l}\text { Mini- } \\
\text { mum }\end{array}$ & Mean & Median & $\begin{array}{c}\text { Maxi- } \\
\text { mum }\end{array}$ \\
\hline Specific conductance & 59 & 150 & 150 & 217 \\
\hline $\mathrm{pH}$ & 6.5 & 7.6 & 7.6 & 8.3 \\
\hline Water temperature & .0 & 8.6 & 6.5 & 27 \\
\hline Dissolved oxygen & 8.0 & 11.4 & 11.8 & 14.4 \\
\hline Dissolved nitrite & $<.004$ & - & $<.004$ & .007 \\
\hline Dissolved ammonia & .005 & .014 & .010 & .077 \\
\hline $\begin{array}{l}\text { Dissolved orthophos- } \\
\text { phate (WY 2003-04) }\end{array}$ & $<.01$ & - & $<.01$ & $<.01$ \\
\hline $\begin{array}{l}\text { Dissolved orthophos- } \\
\text { phate (WY 2005) }\end{array}$ & $<.003$ & - & $<.003$ & .008 \\
\hline Suspended sediment & 1 & 72 & 2 & 752 \\
\hline $\begin{array}{l}{ }^{\text {a} A l l ~ c o n s t i t u e n t s ~ a r e ~ r e p c ~} \\
\text { conductance, which is repo } \\
\text { degrees Celsius; } \mathrm{pH} \text {, which } \\
\text { perature, which is reported }\end{array}$ & $\begin{array}{l}\text { d as mil } \\
\text { as mic } \\
\text { reported } \\
\text { degrees }\end{array}$ & $\begin{array}{l}\text { ams per } \\
\text { iemens p } \\
\text { standard }\end{array}$ & $\begin{array}{l}\text { except fo } \\
\text { entimeter } \\
\text { s; and wo }\end{array}$ & $\begin{array}{l}\text { pecific } \\
25 \\
\text { r tem- }\end{array}$ \\
\hline
\end{tabular}

The estimated load of total nitrogen varied among years during the study (appendix A-1; fig. 21A). The mean annual load of total nitrogen was $1,260,000 \mathrm{lb} / \mathrm{yr}$, with a ratio of the standard error of prediction to the mean load of 2.7 percent (table 2, fig. 21A). An estimated 55 percent of the total nitrogen load was transported during the spring (appendix A-2). The mean yield of total nitrogen $\left(1,830\left(\mathrm{lb} / \mathrm{mi}^{2}\right) / \mathrm{yr}\right)$ was similar to the yield of total nitrogen at most other sites in this study (fig. 21B). 
White River at West Hartford, VT, Station 01144000

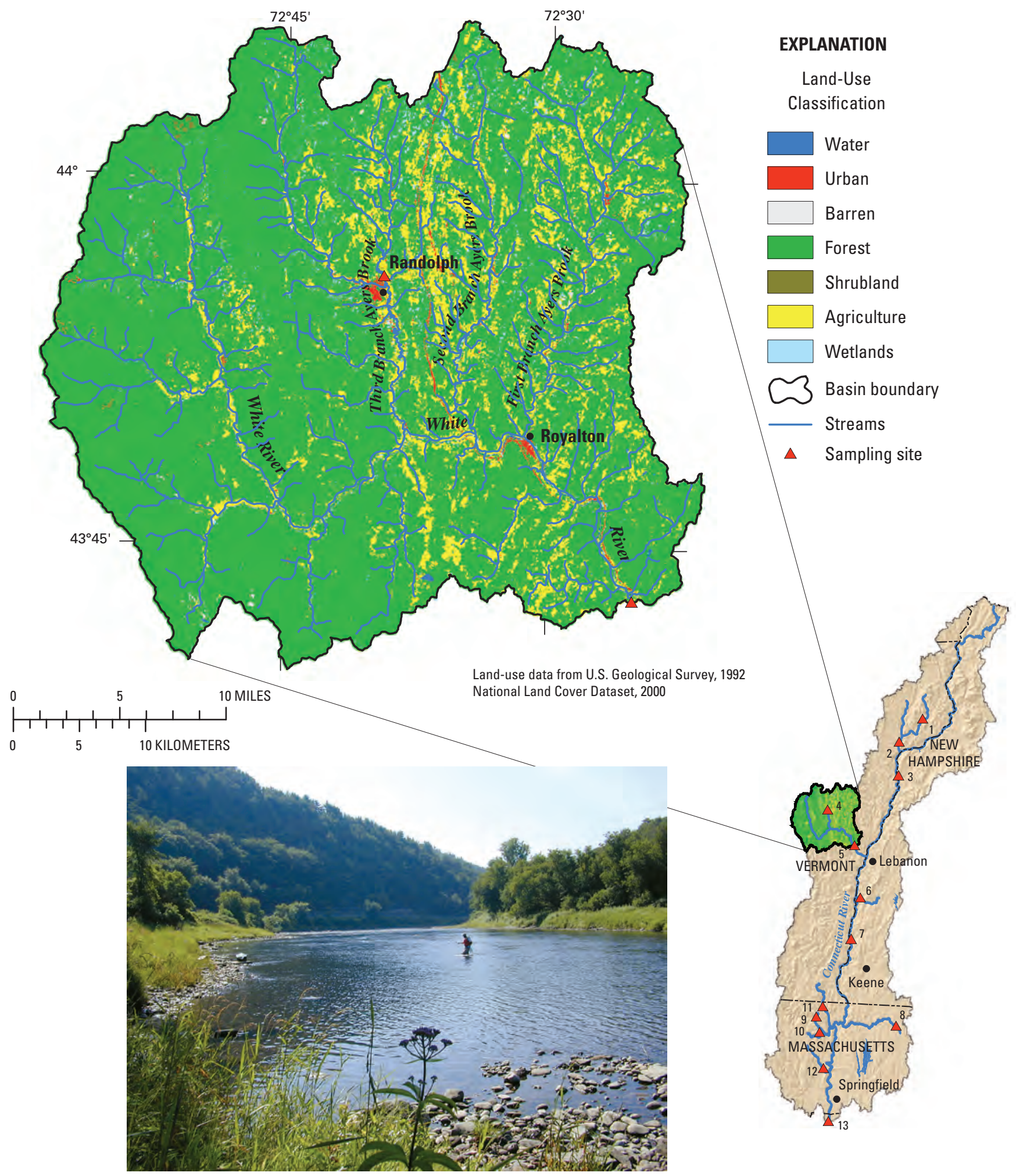

Photograph by Thor Smith, U.S. Geological Survey

Figure 18. Location, land-use classification, and photograph of sampling site for White River at West Hartford, VT, station 01144000. (Refer to table 1 and figure 1 for additional site information.) 

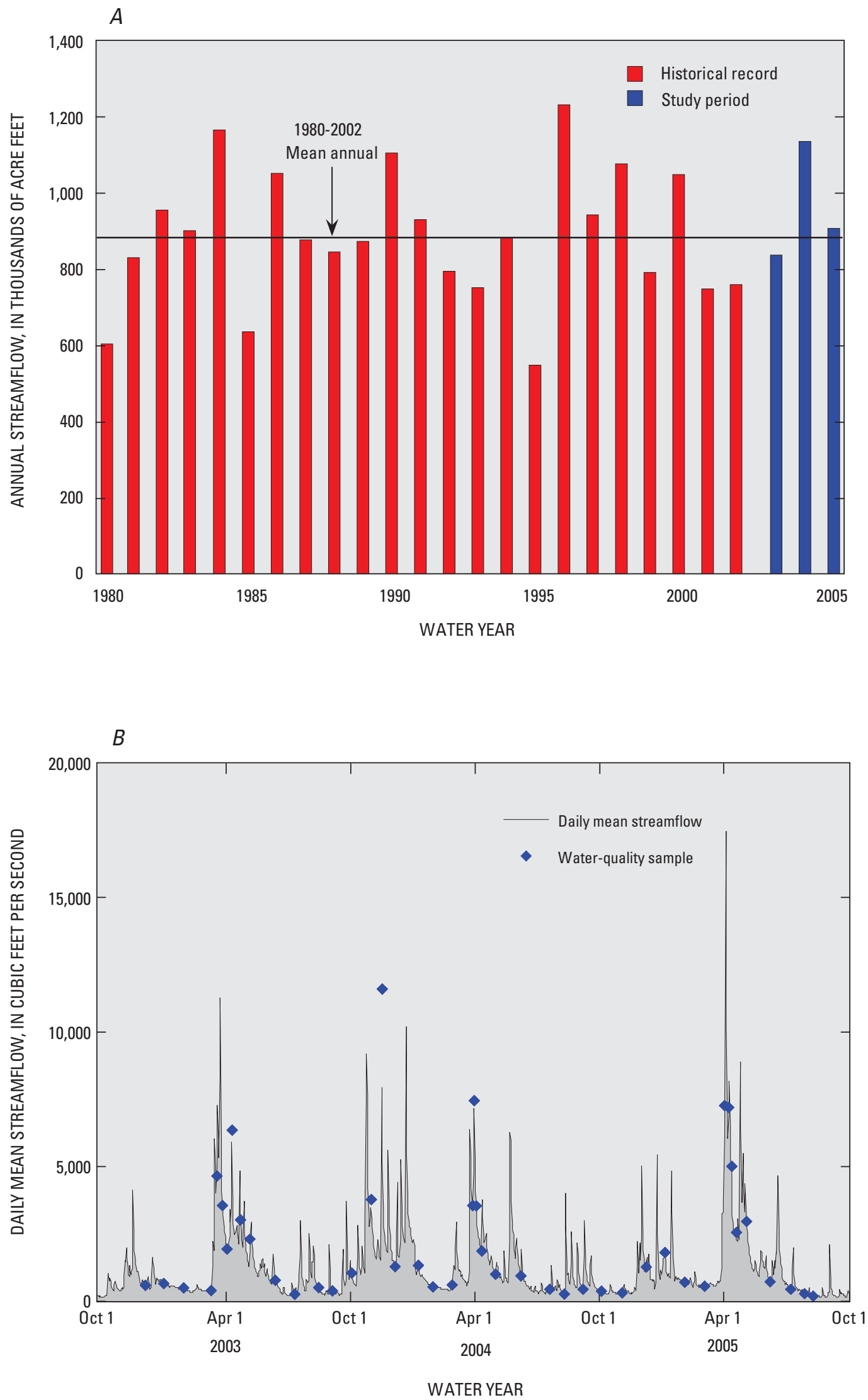

Figure 19. A, Historical and study-period annual streamflow, and $B$, Daily mean streamflow and time distribution of water-quality samples for White River at West Hartford, VT, station 01144000. 

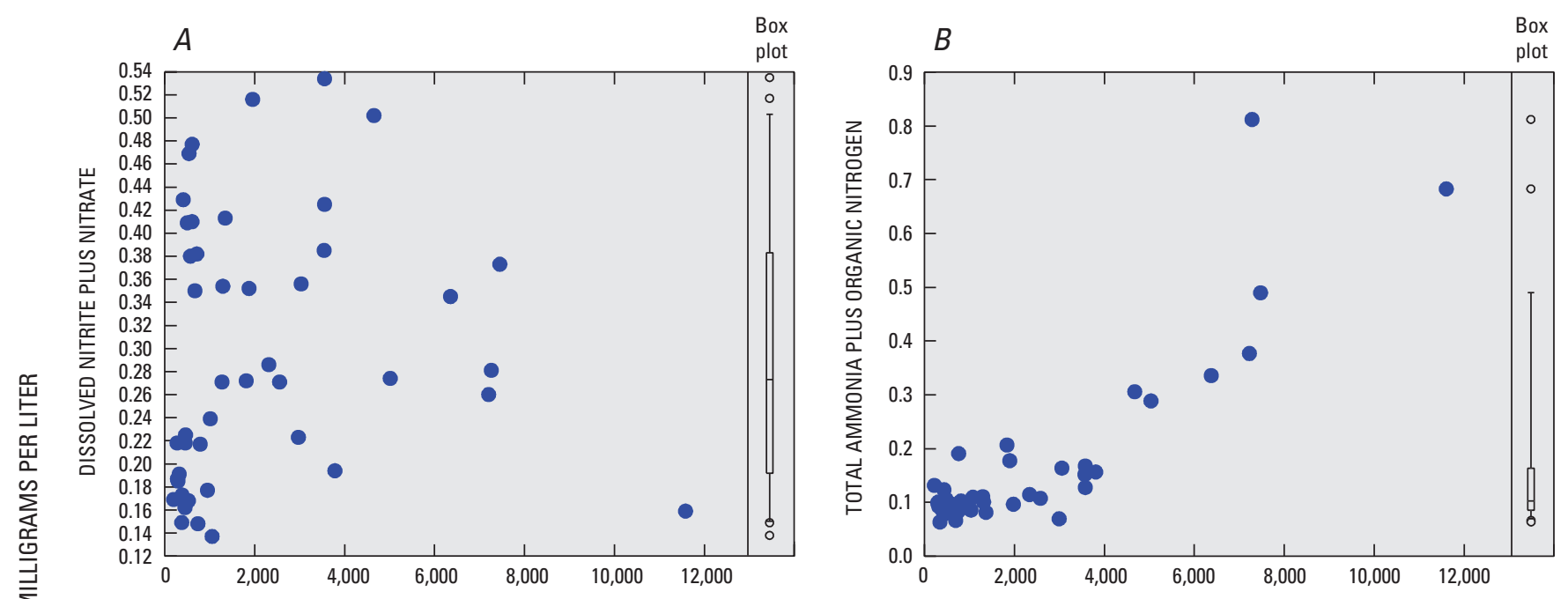

C
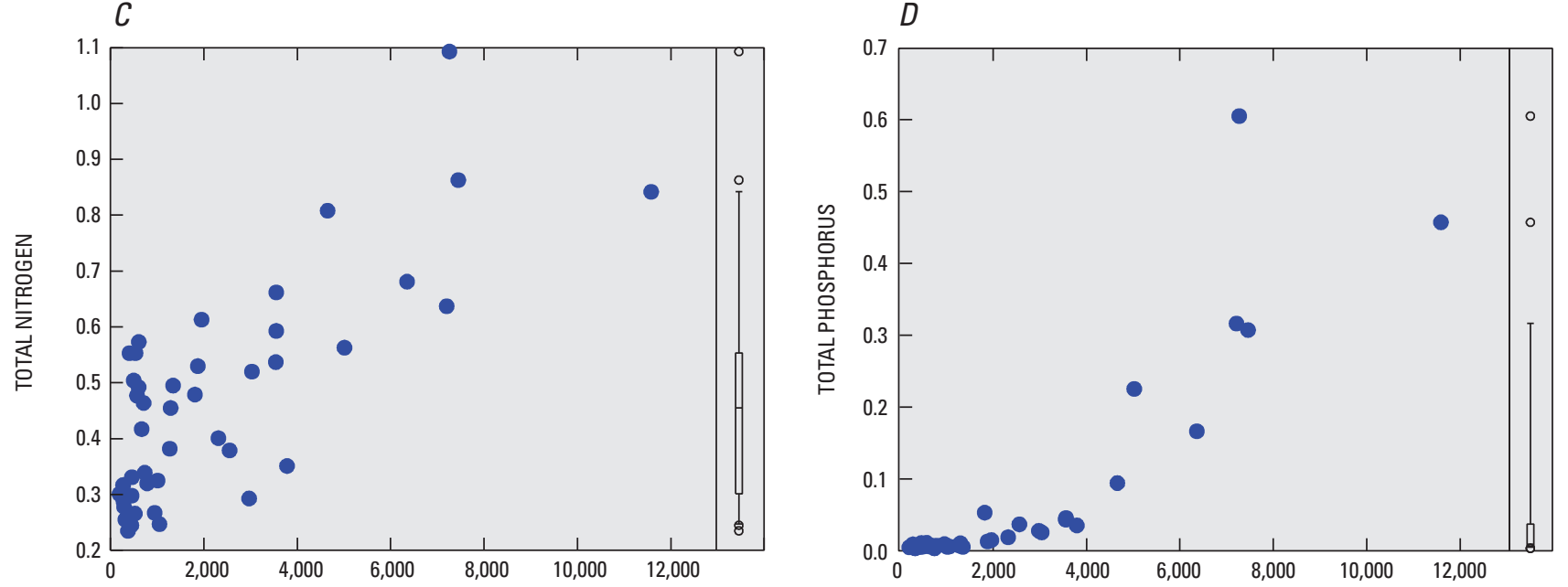

INSTANTANEOUS STREAMFLOW, IN CUBIC FEET PER SECOND
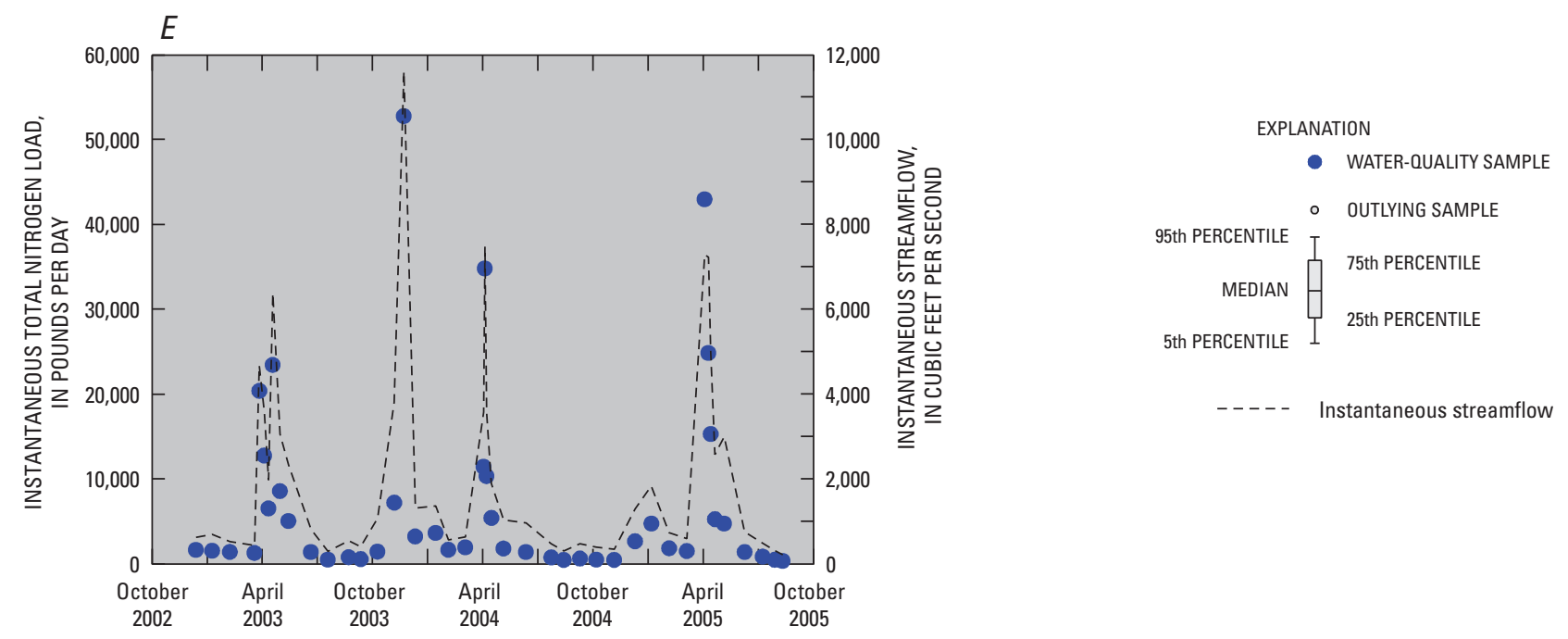

Figure 20. Distribution of $A$, Dissolved nitrite plus nitrate, $B$, Total ammonia plus organic nitrogen, $C$, Total nitrogen, $D$, Total phosphorus concentrations relative to streamflow, and $E$, Instantaneous total nitrogen load relative to time for White River at West Hartford, VT, station 01144000. (Refer to table 1 and figure 1 for station location.) 

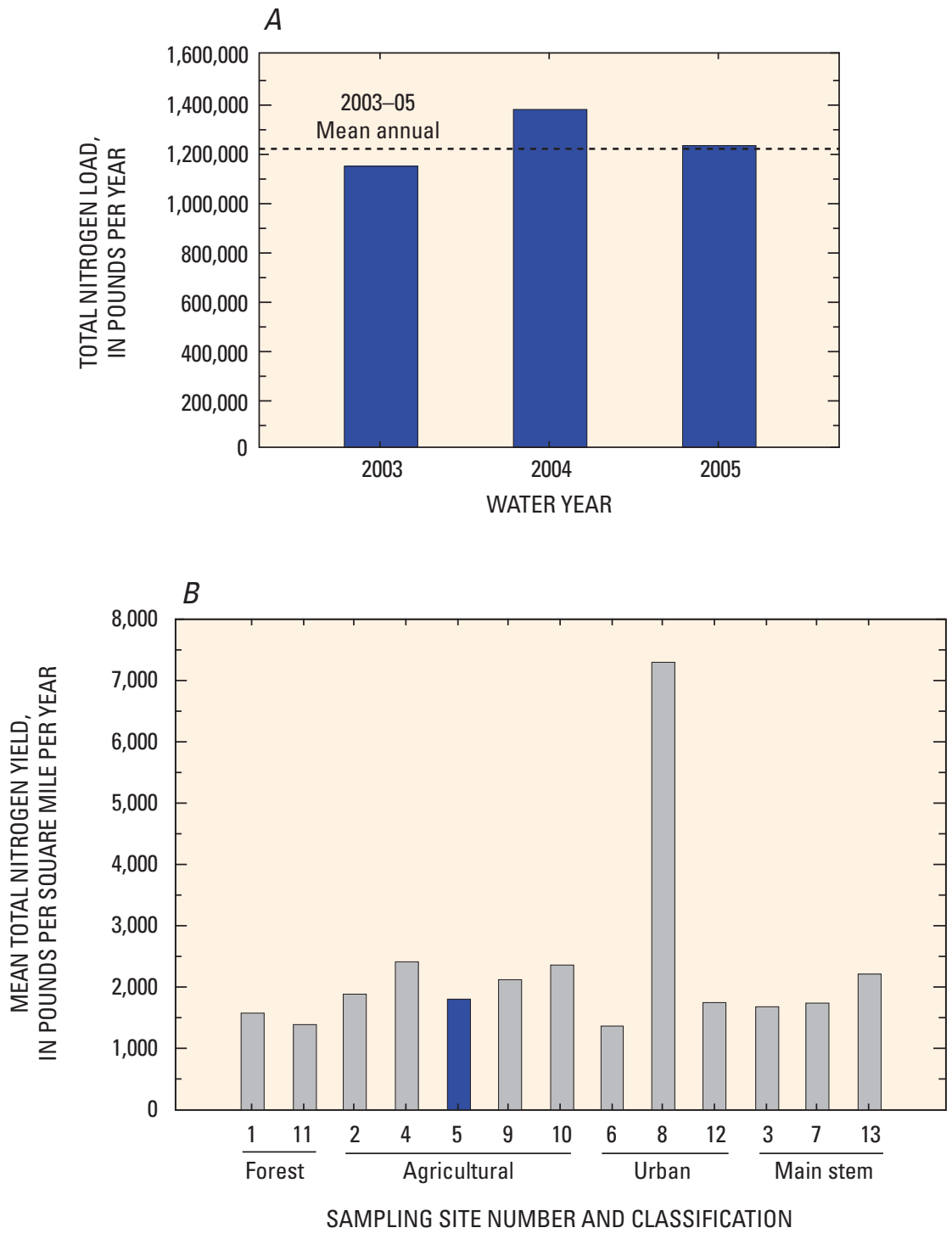

\section{EXPLANATION}

White River at West Hartford, VT

All other river sampling sites

Figure 21. $A$, Total nitrogen load, by year, and $B$, Mean annual total nitrogen yield (2003-05) for White River at West Hartford, VT, station 01144000, in relation to all other river sampling sites. (Refer to table 1 and figure 1 for site names and locations.) 


\section{Sugar River at West Claremont, NH, Station 01152500}

Sugar River at West Claremont, NH, represents an urban site in the study area. A urban site represents potential effects on water quality from urban land use. The contributing drainage basin upstream from the site encompasses $269 \mathrm{mi}^{2}$ and is about 78 percent forested, 9 percent agriculture, 6 percent urban, and 7 percent wetlands and barren (fig. 22). Although the second predominant percentage of land use in the upstream drainage basin is agriculture, this site was selected to represent urban land use because the site is downstream from and near an urban area (fig. 22). The annual streamflow for 1980-2002 averaged 304,000 acre-feet, with considerable year-to-year variation (fig. 23A). The annual streamflow for the data-collection period for water years 2003-05 averaged 341,000 acrefeet (table 1). Streamflow was less than the long-term mean for the first year of this study and greater than the long-term mean for the second and third years (fig. 23A).

Daily mean streamflow and time distribution for 43 water-quality samples are shown in figure 23B. The minimum streamflow at which water samples were collected was $73 \mathrm{ft}^{3} / \mathrm{s}$, and the maximum streamflow at which samples were collected was $4,380 \mathrm{ft}^{3} / \mathrm{s}$.

The minimum concentration of dissolved oxygen was $7.4 \mathrm{mg} / \mathrm{L}$ and was within the water-quality criterion for dissolved oxygen (New Hampshire Department of Environmental Services, 2004). Concentrations of selected water-quality constituents were plotted relative to streamflow (fig. 24). Concentrations of dissolved nitrite plus nitrate ranged from 0.059 to $0.440 \mathrm{mg} / \mathrm{L}$ and showed some scatter but also a slight dilution effect relative to streamflow (fig. 24A). Total ammonia plus organic nitrogen ranged from an estimated 0.16 to $0.82 \mathrm{mg} / \mathrm{L}$ and generally showed no relation to streamflow; however, the maximum concentration of total ammonia plus organic nitrogen was observed at the maximum streamflow at which samples were collected (fig. 24B). Concentrations of total nitrogen ranged from 0.24 to $0.95 \mathrm{mg} / \mathrm{L}$ (fig. 24C).
Concentrations of total phosphorus ranged from 0.011 to $0.275 \mathrm{mg} / \mathrm{L}$ (fig. 24D). Maximum concentrations of total nitrogen and total phosphorus also were observed at the maximum streamflow at which samples were collected. Instantaneous loads of total nitrogen ranged from 187 to $22,400 \mathrm{lb} / \mathrm{d}$ (fig. 24E). Ranges of concentrations or values for water-quality constituents not shown in figure 24 are listed below.

\begin{tabular}{lcccc}
\hline \multirow{2}{*}{$\begin{array}{c}\text { Water-quality } \\
\text { constituent }\end{array}$} & \multicolumn{4}{c}{$<$, less than; - , not calculated } \\
\cline { 2 - 5 } & $\begin{array}{c}\text { Mini- } \\
\text { mum }\end{array}$ & Mean & Median & $\begin{array}{c}\text { Maxi- } \\
\text { mum }\end{array}$ \\
\hline Specific conductance & 49 & 120 & 121 & 191 \\
$\mathrm{pH}$ & 6.1 & 7.0 & 6.8 & 8.7 \\
Water temperature & .0 & 9.5 & 7.5 & 26 \\
Dissolved oxygen & 7.4 & 11.8 & 11.8 & 14.4 \\
Dissolved nitrite & $<.004$ & - & $<.004$ & .005 \\
Dissolved ammonia & .005 & .038 & .021 & .156 \\
Dissolved orthophos- & $<.01$ & - & $<.01$ & .01 \\
$\quad$ phate (WY 2003-04) & & & & \\
Dissolved orthophos- & $<.003$ & - & $<.003$ & .005 \\
$\quad$ phate (WY 2005) & & & 2 & 267 \\
Suspended sediment & 1 & 14 & 2 & \\
\hline
\end{tabular}

${ }^{a}$ All constituents are reported as milligrams per liter except for specific conductance, which is reported as microsiemens per centimeter at 25 degrees Celsius; $\mathrm{pH}$, which is reported as standard units; and water temperature, which is reported as degrees Celsius; WY, water year.

The estimated load of total nitrogen varied among years during the study (appendix A-1; fig. 25A). The mean annual load of total nitrogen was $372,000 \mathrm{lb} / \mathrm{yr}$, with a ratio of the standard error of prediction to the mean load of 3.9 percent (table 2, fig. 25A). An estimated 49 percent of the total nitrogen load was transported during the spring (appendix A-2). The mean yield of total nitrogen $\left(1,380\left(\mathrm{lb} / \mathrm{mi}^{2}\right) / \mathrm{yr}\right)$ was less than the mean yield of total nitrogen from most other sites in the study (fig. 25B). 
Sugar River at West Claremont, NH, Station 01152500

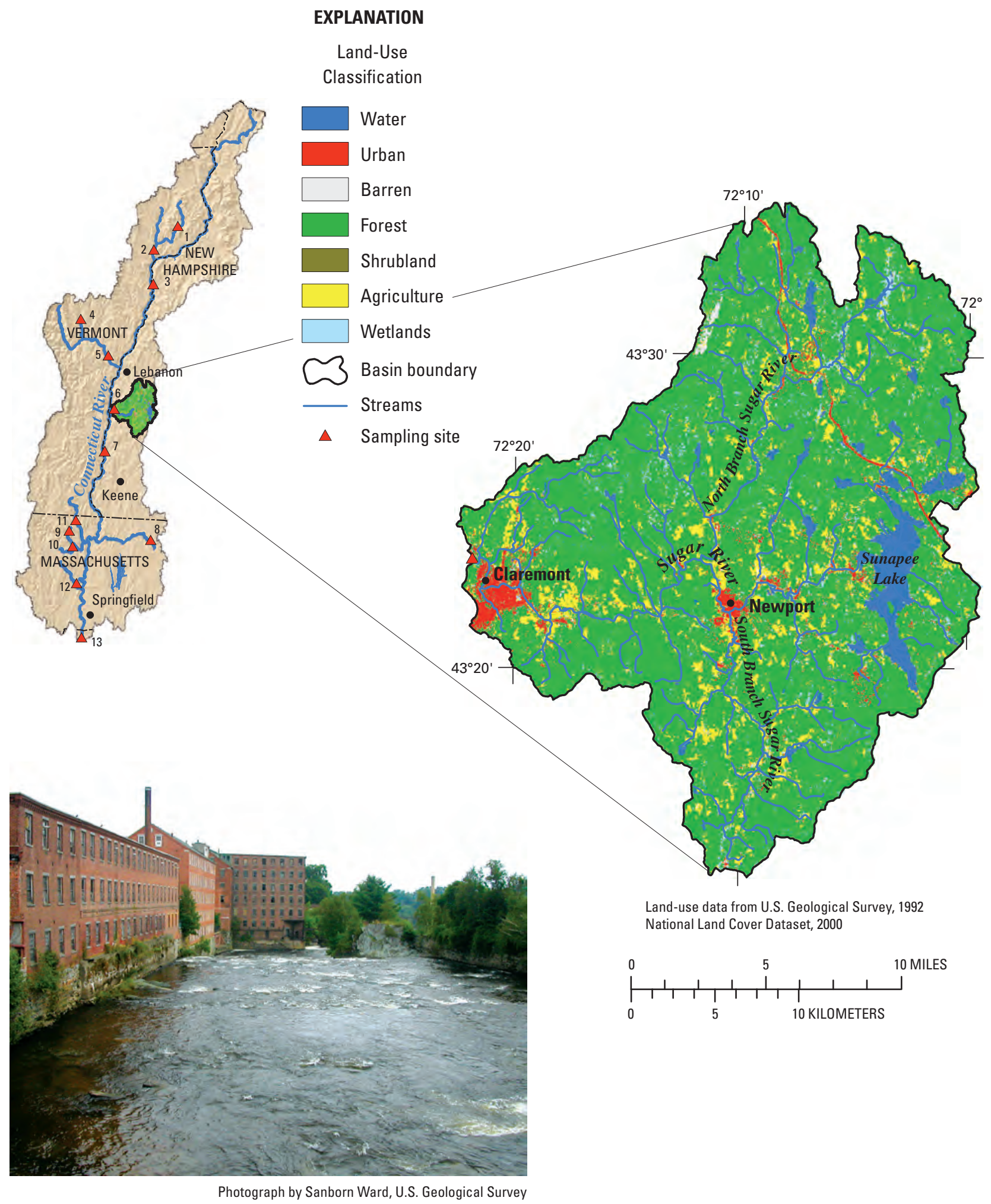

Figure 22. Location, land-use classification, and photograph of urban area upstream of sampling site for Sugar River at West Claremont, $\mathrm{NH}$, station 01152500. (Refer to table 1 and figure 1 for additional site information.) 

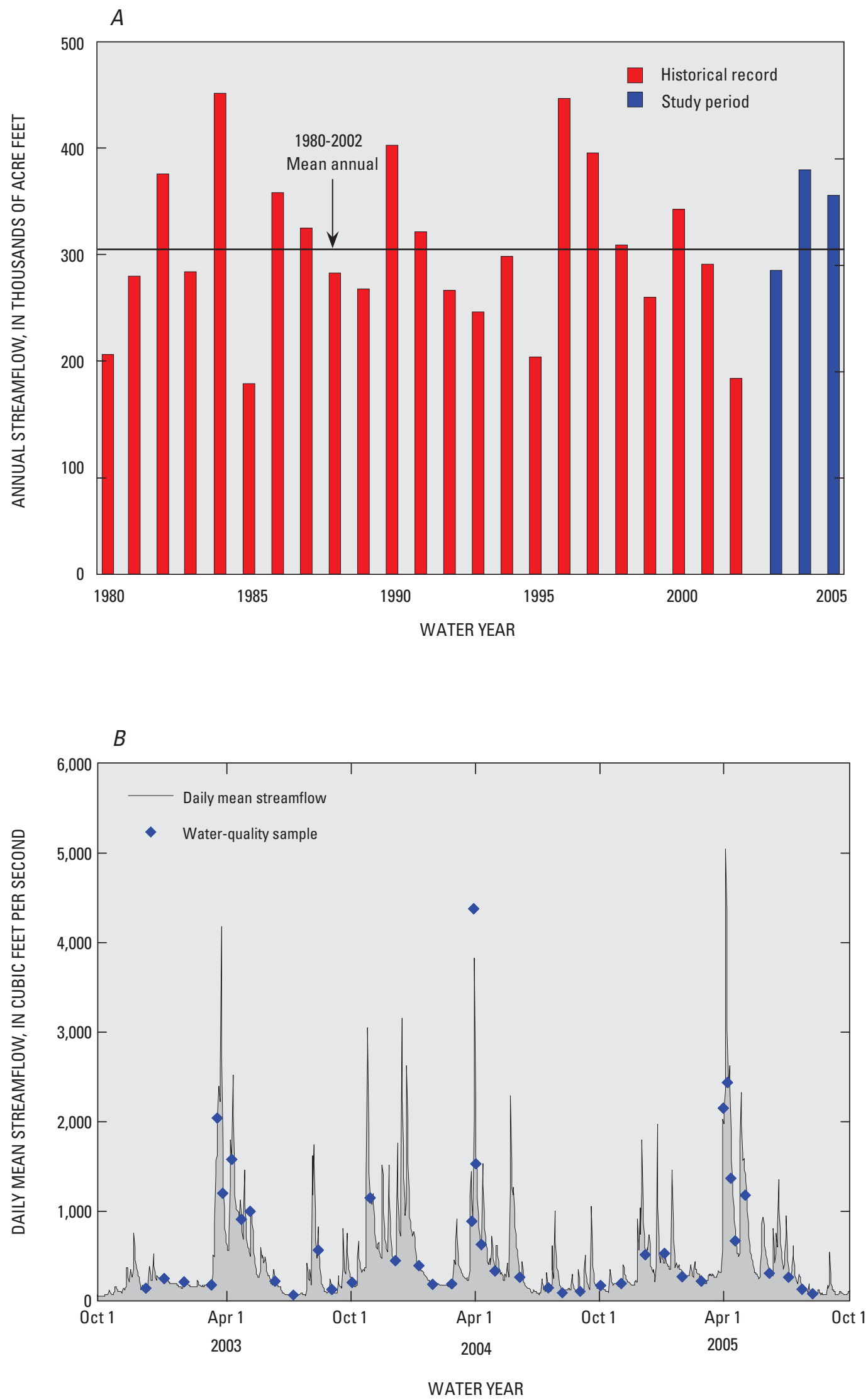

Figure 23. $\quad A$, Historical and study-period annual streamflow, and $B$, Daily mean streamflow and time distribution of water-quality samples for Sugar River at West Claremont, NH, station 01152500. 

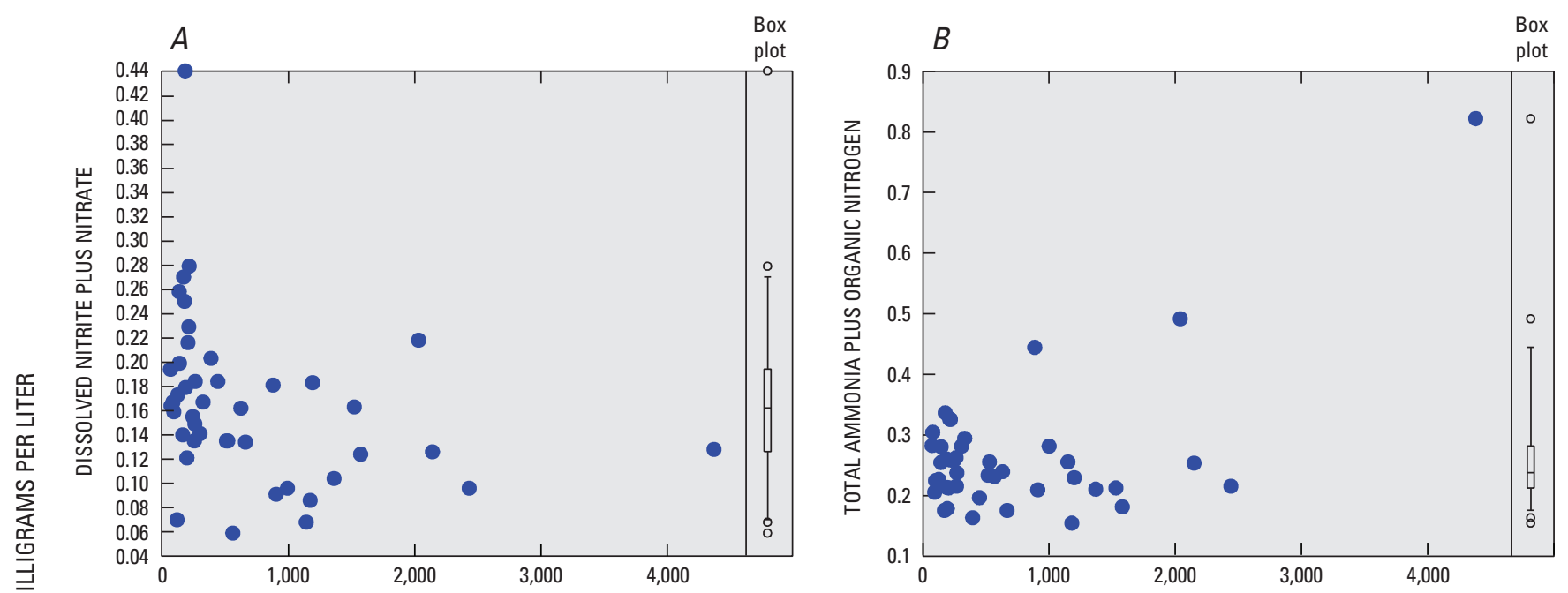

C
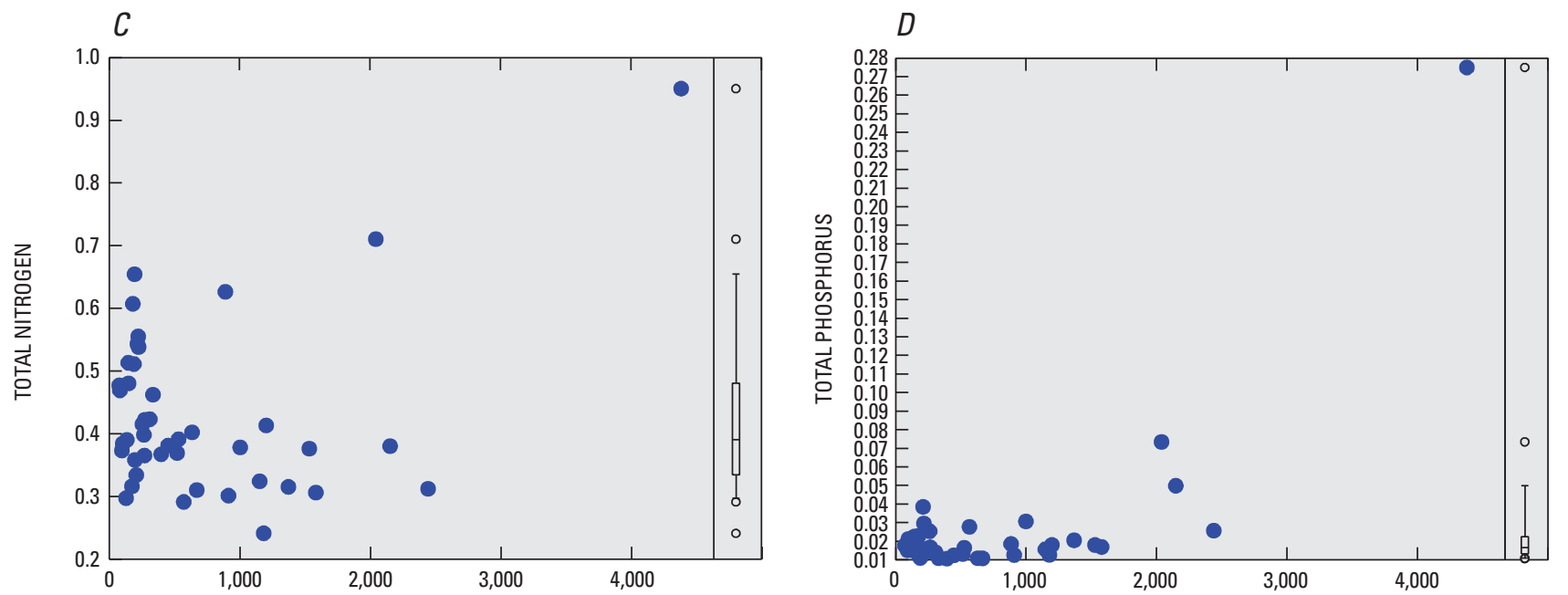

INSTANTANEOUS STREAMFLOW, IN CUBIC FEET PER SECOND
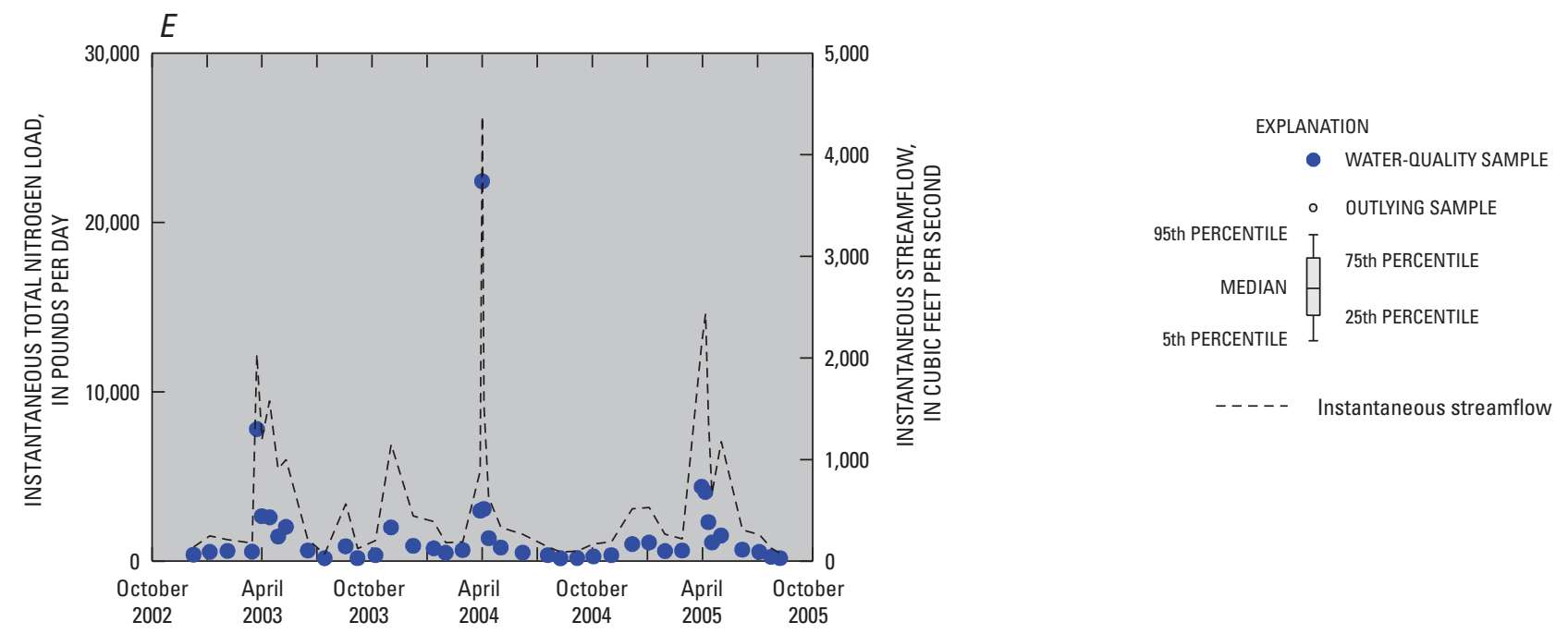

Figure 24. Distribution of $A$, Dissolved nitrite plus nitrate, $B$, Total ammonia plus organic nitrogen, $C$, Total nitrogen, $D$, Total phosphorus concentrations relative to streamflow, and $E$, Instantaneous total nitrogen load relative to time for Sugar River at West Claremont, NH, station 01152500. (Refer to table 1 and figure 1 for station location.) 

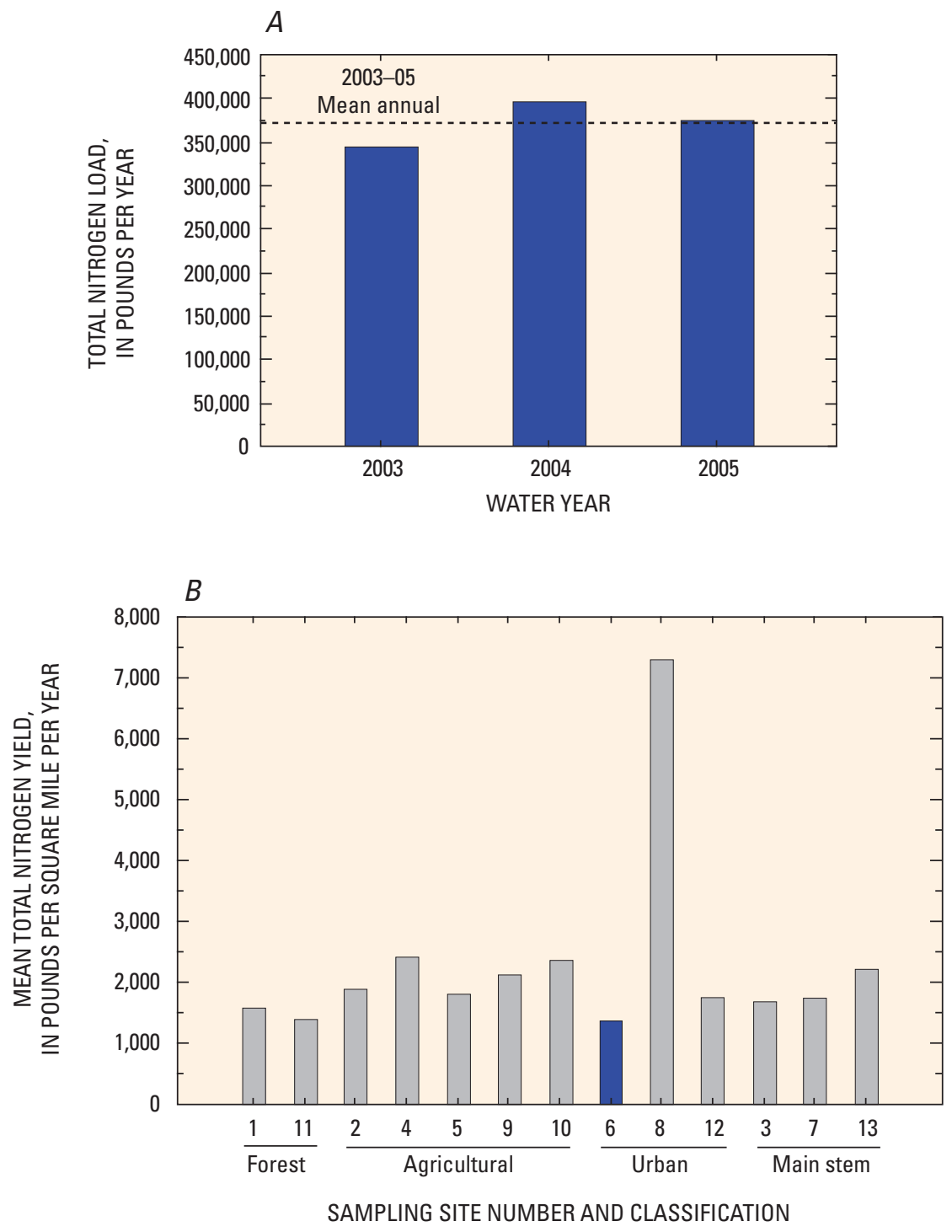

EXPLANATION

Sugar River at West Claremont, NH

All other river sampling sites

Figure 25. A, Total nitrogen load, by year, and $B$, Mean annual total nitrogen yield (2003-05) for Sugar River at West Claremont, $\mathrm{NH}$, station 01152500 , in relation to all other river sampling sites. (Refer to table 1 and figure 1 for site names and locations.) 


\section{Connecticut River at North Walpole, NH, Station 01154500}

Connecticut River at North Walpole, NH, represents a main-stem site for the study area. The contributing drainage basin upstream from the site encompasses 5,493 $\mathrm{mi}^{2}$ and is about 83 percent forested, 9 percent agriculture, 2 percent urban, and 6 percent wetlands and barren (fig. 26). Annual streamflow for 1980-2002 averaged 7,160,000 acre-feet, with considerable year-to-year variation (fig. 27A). Annual streamflow for the data-collection period for water years 2003-05 averaged 7,070,000 acre-feet (table 1). Streamflow was less than the long-term mean for the first year of the study, greater than the long-term mean for the second year, and about equal to the long-term mean for the third year (fig. 27A).

Daily mean streamflow and time distribution for 44 water-quality samples are shown in figure $27 \mathrm{~B}$. The minimum streamflow at which water samples were collected was $1,290 \mathrm{ft}^{3} / \mathrm{s}$, and the maximum streamflow at which samples were collected was $46,700 \mathrm{ft}^{3} / \mathrm{s}$.

The minimum concentration of dissolved oxygen was $6.9 \mathrm{mg} / \mathrm{L}$ and was within the water-quality criterion for dissolved oxygen (New Hampshire Department of Environmental Services, 2004). Concentrations of selected water-quality constituents were plotted relative to streamflow (fig. 28). Concentrations of dissolved nitrite plus nitrate ranged from 0.136 to $0.406 \mathrm{mg} / \mathrm{L}$ and showed a poorly defined relation to streamflow (fig. 28A). Total ammonia plus organic nitrogen ranged from an estimated concentration of 0.15 to $0.46 \mathrm{mg} / \mathrm{L}$ and showed a slight increase with an increase in streamflow (fig. 28B). Concentrations of total nitrogen ranged from 0.28 to $0.83 \mathrm{mg} / \mathrm{L}$ (fig. $28 \mathrm{C}$ ) and also showed a slight variation with streamflow. Concentrations of total phosphorus ranged from 0.005 to $0.155 \mathrm{mg} / \mathrm{L}$ and increased with an increase in streamflow (fig. 28D). Instantaneous loads of total nitrogen ranged from 2,460 to $186,000 \mathrm{lb} / \mathrm{d}$ (fig. 28E). Ranges of concentrations or values for water-quality constituents not shown in figure 28 are listed below.

\begin{tabular}{|c|c|c|c|c|}
\hline \multirow{2}{*}{$\begin{array}{l}\text { Water-quality } \\
\text { constituent }^{\mathrm{a}}\end{array}$} & \multicolumn{4}{|c|}{$<$, less than; - , not calculated } \\
\hline & $\begin{array}{l}\text { Mini- } \\
\text { mum }\end{array}$ & Mean & Median & $\begin{array}{c}\text { Maxi- } \\
\text { mum }\end{array}$ \\
\hline Specific conductance & 64 & 117 & 114 & 172 \\
\hline $\mathrm{pH}$ & 6.2 & 7.3 & 7.3 & 7.8 \\
\hline Water temperature & .0 & 9.5 & 7.2 & 27 \\
\hline Dissolved oxygen & 6.9 & 11.2 & 11.9 & 14.8 \\
\hline Dissolved nitrite & $<.004$ & - & $<.004$ & .006 \\
\hline Dissolved ammonia & .005 & .021 & .017 & .055 \\
\hline $\begin{array}{l}\text { Dissolved orthophos- } \\
\text { phate (WY 2003-04) }\end{array}$ & $<.01$ & - & $<.01$ & .01 \\
\hline $\begin{array}{l}\text { Dissolved orthophos- } \\
\text { phate (WY 2005) }\end{array}$ & $<.003$ & - & $<.003$ & .003 \\
\hline Suspended sediment & 1 & 13 & 2 & 169 \\
\hline
\end{tabular}

The estimated load of total nitrogen varied among years during the study (appendix A-1; fig. 29A). The mean annual load of total nitrogen was $9,600,000 \mathrm{lb} / \mathrm{yr}$, with a ratio of the standard error of prediction to the mean load of 4.1 percent (table 2, fig. 29A). An estimated 47 percent of the total nitrogen load was transported during the spring (appendix A-2). The mean yield of total nitrogen $\left(1,750\left(\mathrm{lb} / \mathrm{mi}^{2}\right) / \mathrm{yr}\right)$ was similar to the yield of total nitrogen at the Connecticut River at Wells River, VT (site 3), but less than the yield of total nitrogen at the Connecticut River at Thompsonville, CT (site 13), the site representing the outlet to the upper basin (fig. 29B). 
Connecticut River at North Walpole, NH, Station 01154500
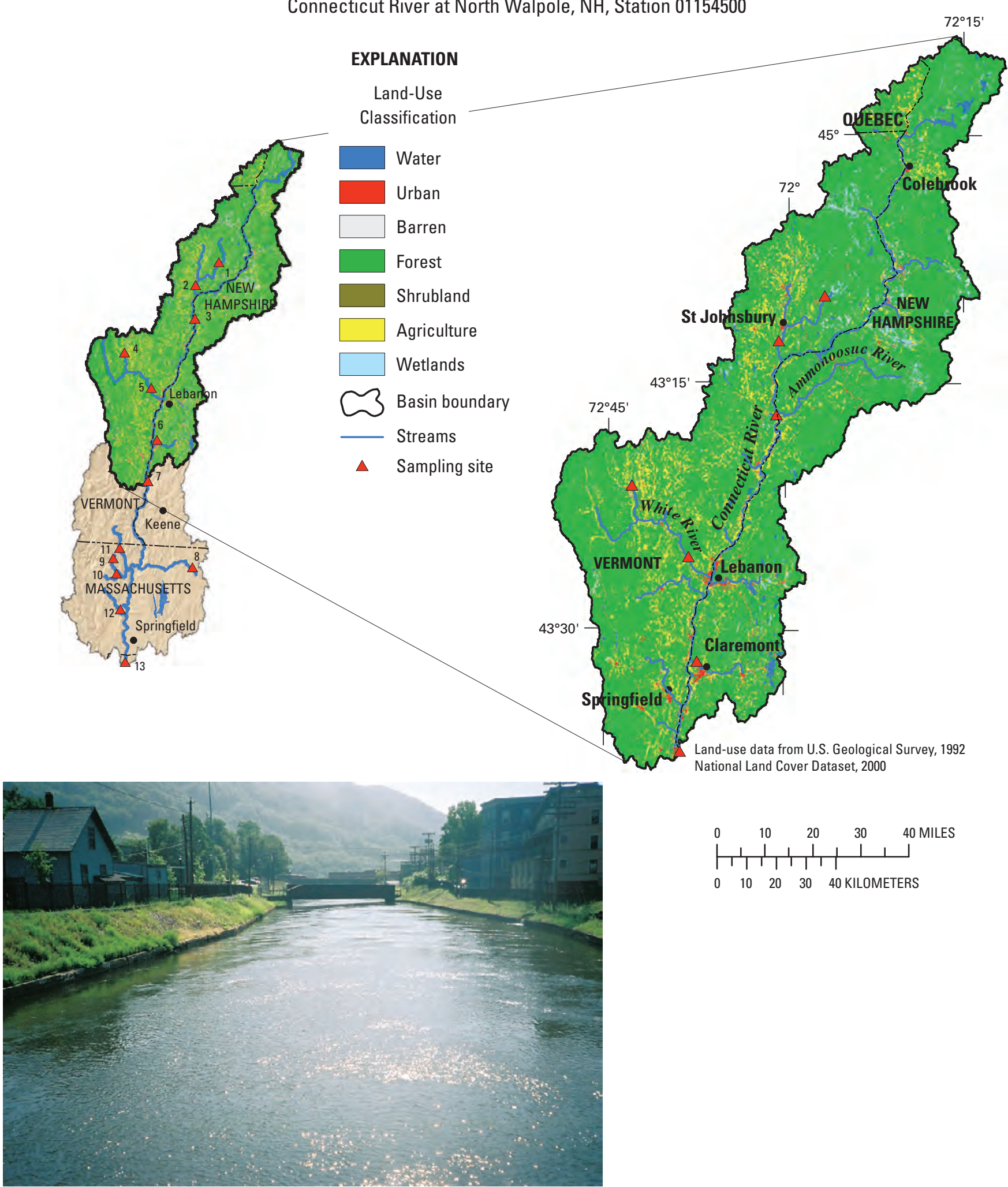

Photograph by Thor Smith, U.S. Geological Survey

Figure 26. Location, land-use classification, and photograph of sampling site for Connecticut River at North Walpole, NH, station 01154500. (Refer to table 1 and figure 1 for additional site information.) 

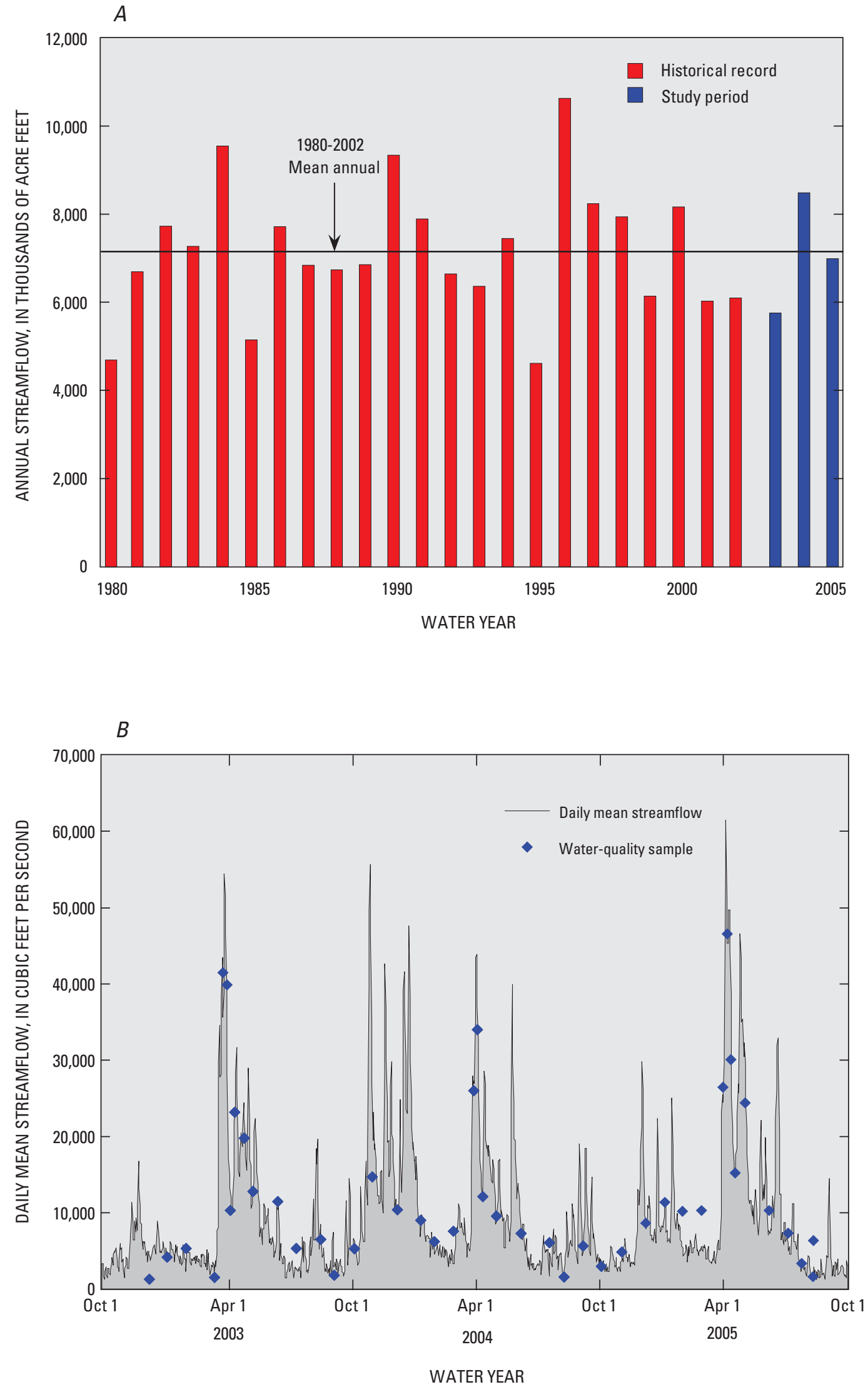

Figure 27. A, Historical and study-period annual streamflow, and $B$, Daily mean streamflow and time distribution of water-quality samples for Connecticut River at North Walpole, NH, station 01154500. 

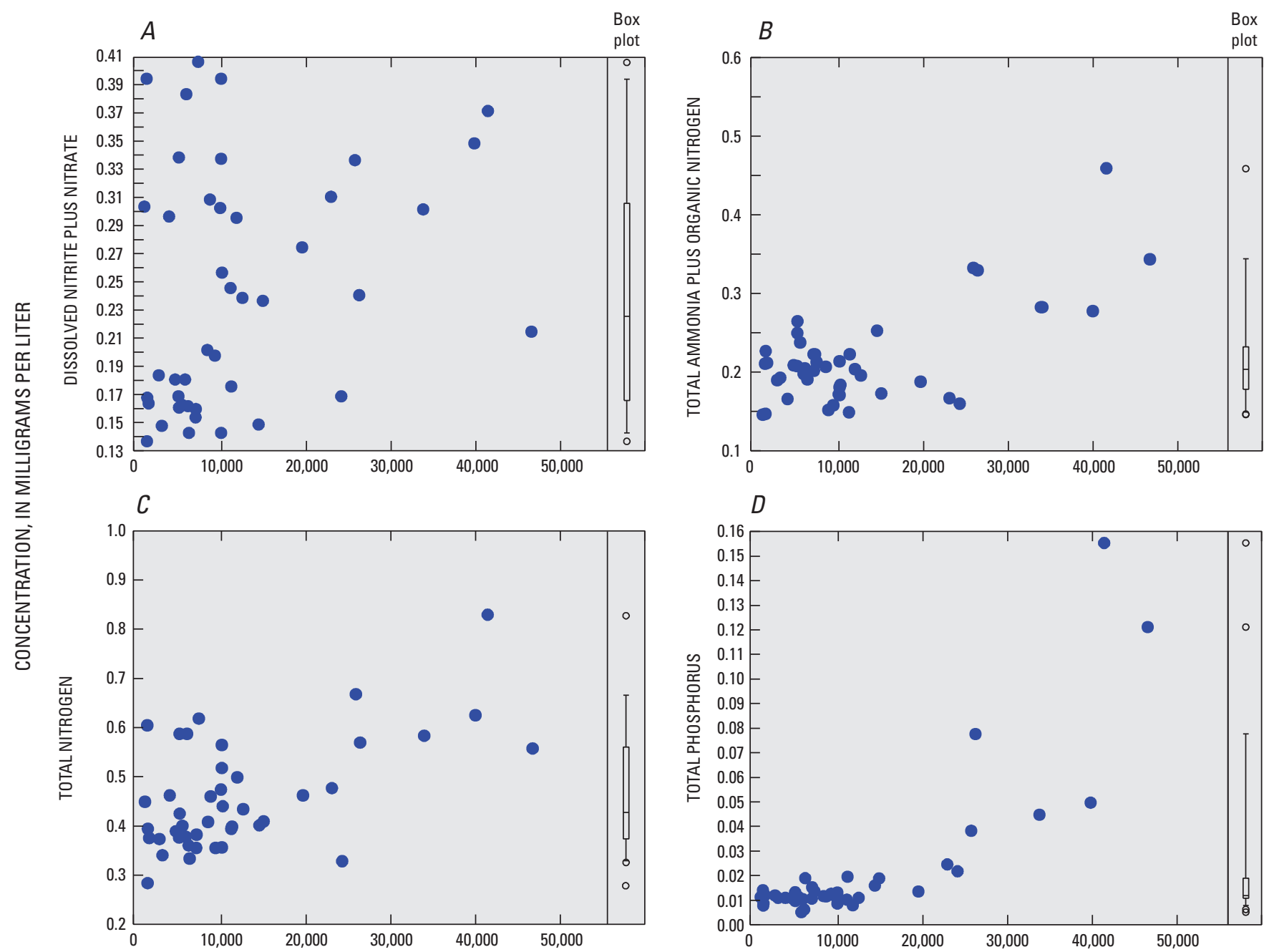

INSTANTANEOUS STREAMFLOW, IN CUBIC FEET PER SECOND
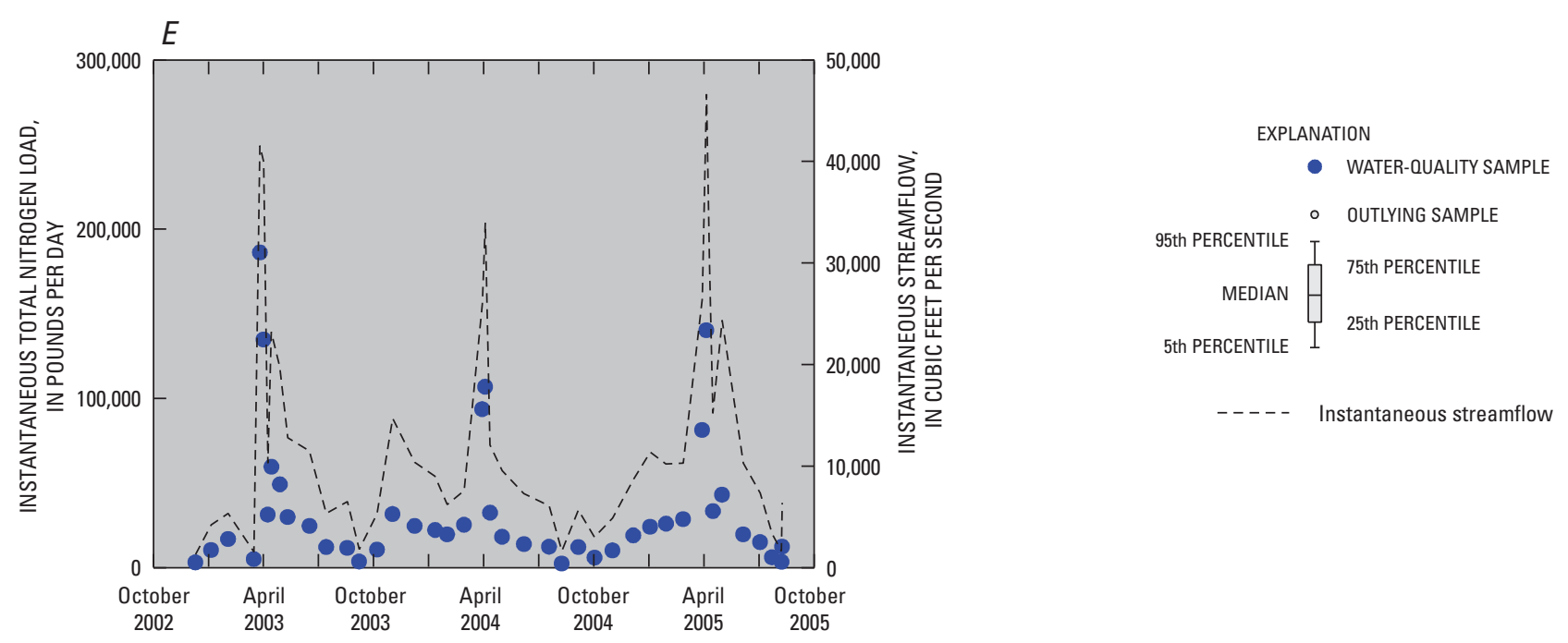

Figure 28. Distribution of $A$, Dissolved nitrite plus nitrate, $B$, Total ammonia plus organic nitrogen, $C$, Total nitrogen, $D$, Total phosphorus concentrations relative to streamflow, and $E$, Instantaneous total nitrogen load relative to time for Connecticut River at North Walpole, NH, station 01154500. (Refer to table 1 and figure 1 for station location.) 

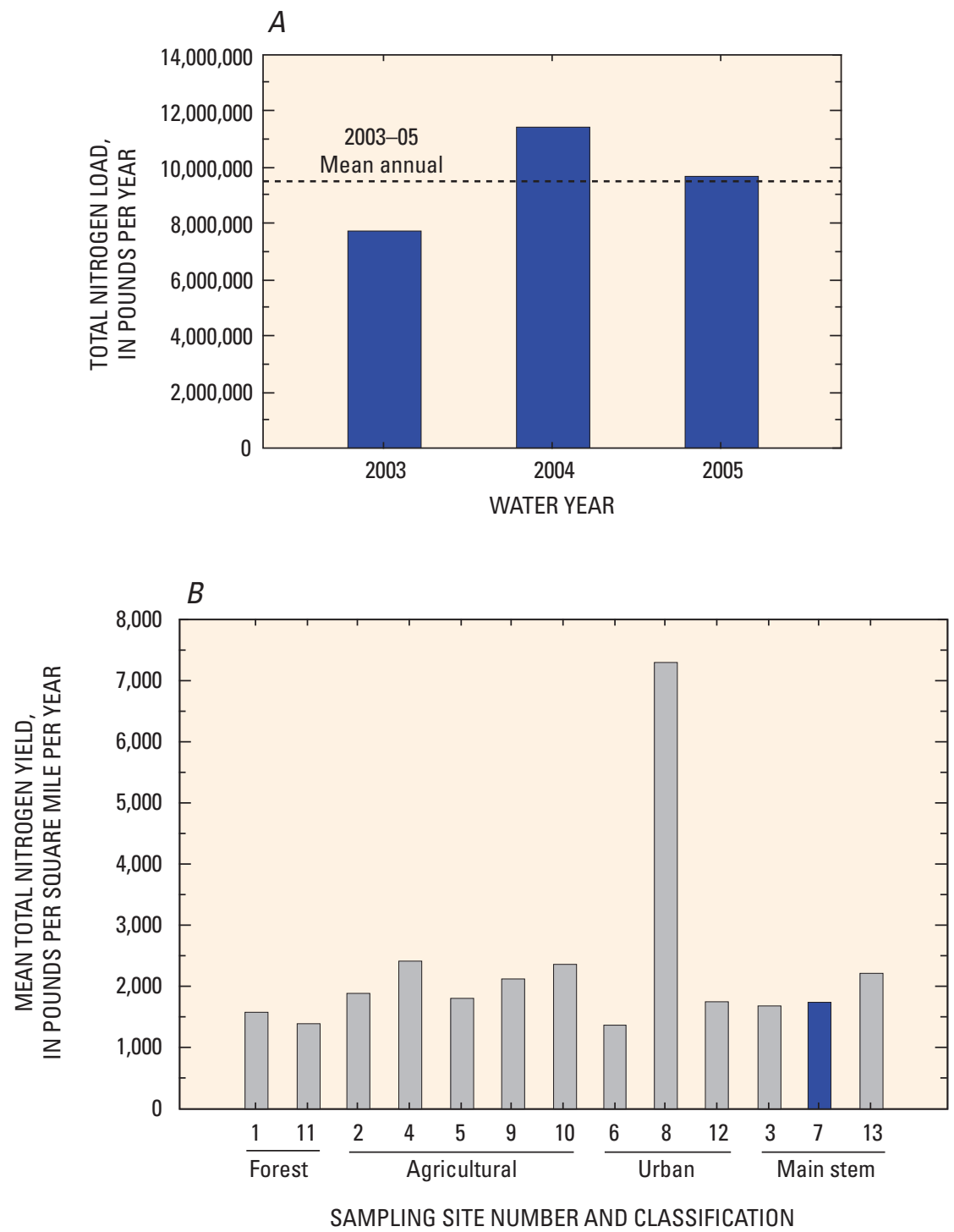

EXPLANATION

Connecticut River at Walpole, NH

All other river sampling sites

Figure 29. $\quad A$, Total nitrogen load, by year, and $B$, Mean annual total nitrogen yield (2003-05) for Connecticut River at North Walpole, $\mathrm{NH}$, station 01154500 , in relation to all other river sampling sites. (Refer to table 1 and figure 1 for site names and locations.) 


\section{Otter River at Otter River, MA, Station 01163200}

Otter River at Otter River, MA, represents a urban site in the study area. The contributing drainage basin upstream from the site encompasses about $34 \mathrm{mi}^{2}$ and is about 58 percent forested, 6 percent agriculture, 22 percent urban, and 14 percent wetlands and barren (fig. 30). The annual streamflow for 1980-2002 averaged 45,300 acre-feet, with considerable year-to-year variation (fig. 31A). Annual streamflow for the data-collection period for water years 2003-05 averaged 53,400 acre-feet (table 1). Streamflow was greater than the long-term mean for all 3 years of the study (fig. 31A).

Daily mean streamflow and time distribution for 42 water samples are shown in figure 31B. The minimum streamflow at which samples were collected was $6.4 \mathrm{ft}^{3} / \mathrm{s}$, and the maximum streamflow was $348 \mathrm{ft}^{3} / \mathrm{s}$.

The minimum concentration of dissolved oxygen was $6.6 \mathrm{mg} / \mathrm{L}$ and was within the Massachusetts water-quality criterion for dissolved oxygen (Massachusetts Department of Environmental Protection, 2005). Concentrations of selected water-quality constituents were plotted relative to streamflow (fig. 32). Concentrations of dissolved nitrite plus nitrate ranged from 0.226 to $9.66 \mathrm{mg} / \mathrm{L}$ and showed a typical dilution curve relative to streamflow (fig. 32A). Total ammonia plus organic nitrogen ranged from an estimated 0.33 to $1.1 \mathrm{mg} / \mathrm{L}$ and showed a decrease in concentrations with an increase in streamflow with the exception of the sample collected at a streamflow of $348 \mathrm{ft}^{3} / \mathrm{s}$. This sample was collected just prior to the first peak in maximum daily mean streamflow during snowmelt in water year 2005 (fig. 32B). Concentrations of total nitrogen ranged from 0.59 to $10 \mathrm{mg} / \mathrm{L}$ and also showed a well-defined relation with streamflow (fig. 32C). The water quality at this site is dominated by effluent and most of the total nitrogen is in the form of dissolved nitrite plus nitrate. This relation is typical of dilution curves found at sites that may be dominated by wastewater-treatment effluent. Concentrations of total phosphorus ranged from 0.023 to
$0.337 \mathrm{mg} / \mathrm{L}$ (fig. 32D). Instantaneous loads of total nitrogen ranged from 268 to 2,140 lb/d (fig. 32E). Ranges of concentrations or values for water-quality constituents not shown in figure 32 are listed below.

\begin{tabular}{lcccc}
\hline \multirow{2}{*}{$\begin{array}{c}\text { Water-quality } \\
\text { constituent }^{\mathrm{a}}\end{array}$} & \multicolumn{4}{c}{$<$, less than; - not calculated } \\
\cline { 2 - 5 } & $\begin{array}{c}\text { Mini- } \\
\text { mum }\end{array}$ & Mean & Median & $\begin{array}{c}\text { Maxi- } \\
\text { mum }\end{array}$ \\
\hline Specific conductance & 209 & 378 & 362 & 765 \\
$\mathrm{pH}$ & 5.7 & 6.3 & 6.3 & 7.0 \\
Water temperature & .0 & 10.1 & 8.6 & 24.9 \\
Dissolved oxygen & 6.6 & 9.8 & 9.3 & 14.7 \\
Dissolved nitrite & .004 & .024 & .016 & .214 \\
Dissolved ammonia & $<.020$ & .165 & .104 & .710 \\
Dissolved orthophos- & .01 & .06 & .03 & .21 \\
$\quad$ phate (WY 2003-05) & & & & \\
Suspended sediment & 2 & 6 & 6 & 16 \\
\hline
\end{tabular}

${ }^{a}$ All constituents are reported as milligrams per liter except for specific conductance, which is reported as microsiemens per centimeter at 25 degrees Celsius; $\mathrm{pH}$, which is reported as standard units; and water temperature, which is reported as degrees Celsius; WY, water year.

The estimated load of total nitrogen was similar during the first and second year of the study and slightly greater during the third year (appendix A-1; fig. 33A). The mean annual load of total nitrogen was $249,000 \mathrm{lb} / \mathrm{yr}$, with a ratio of the standard error of prediction to the mean load of 3.9 percent (table 2, fig. 33A). An estimated 29 and 22 percent of the total nitrogen load was transported in the spring and summer, respectively. The load of total nitrogen at this site was similar among seasons (appendix A-2). The mean yield of total nitrogen $\left(7,300\left(\mathrm{lb} / \mathrm{mi}^{2}\right) / \mathrm{yr}\right)$ was greater than at all other sites (fig. 33B). Trench (1999) reported similar results in that basins receiving effluent from wastewater-treatment facilities generally are greater in yields of total nitrogen than other basins. 
Otter River at Otter River, MA, Station 01163200
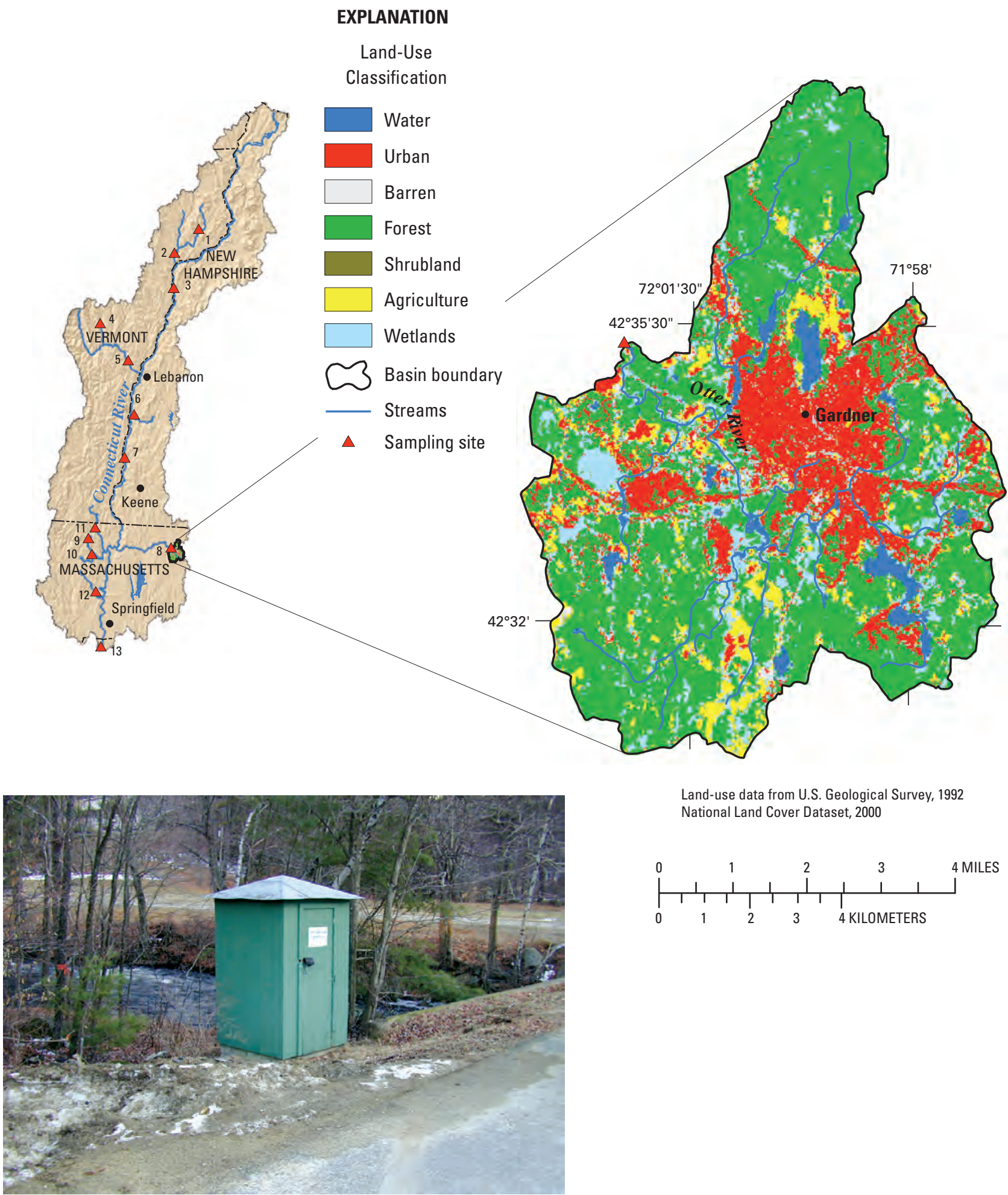

Land-use data from U.S. Geological Survey, 1992 National Land Cover Dataset, 2000

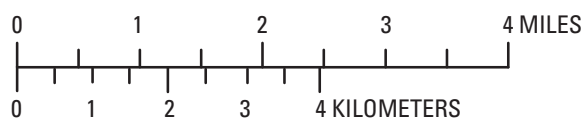

Photograph by Tim Driskell, U.S. Geological Survey

Figure 30. Location, land-use cover classification, and photograph of sampling site for Otter River at Otter River, MA, station 01163200. (Refer to table 1 and figure 1 for additional site information.) 

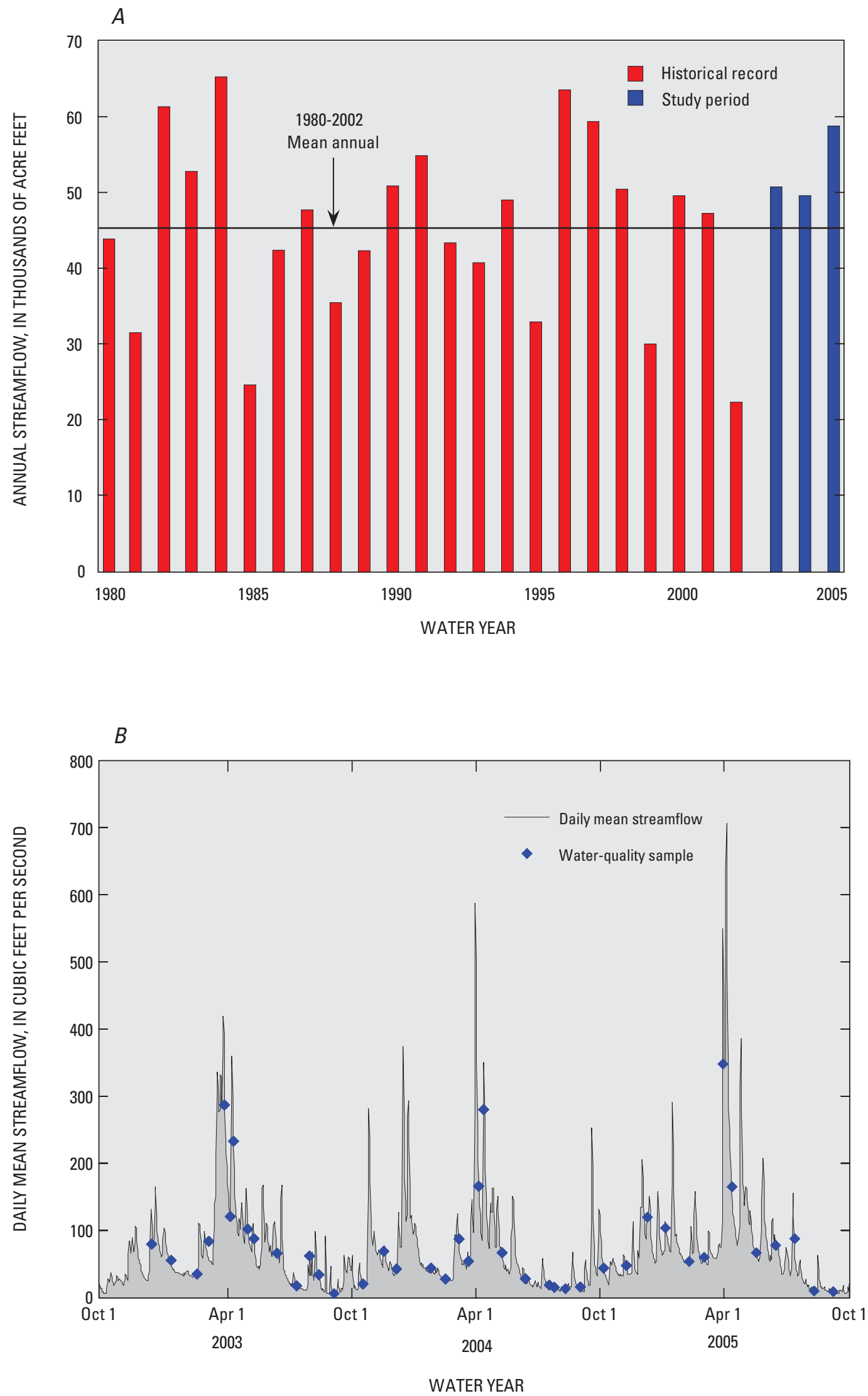

Figure 31. $A$, Historical and study-period annual streamflow, and $B$, Daily mean streamflow and time distribution of water-quality samples for Otter River at Otter River, MA, station 01163200. 

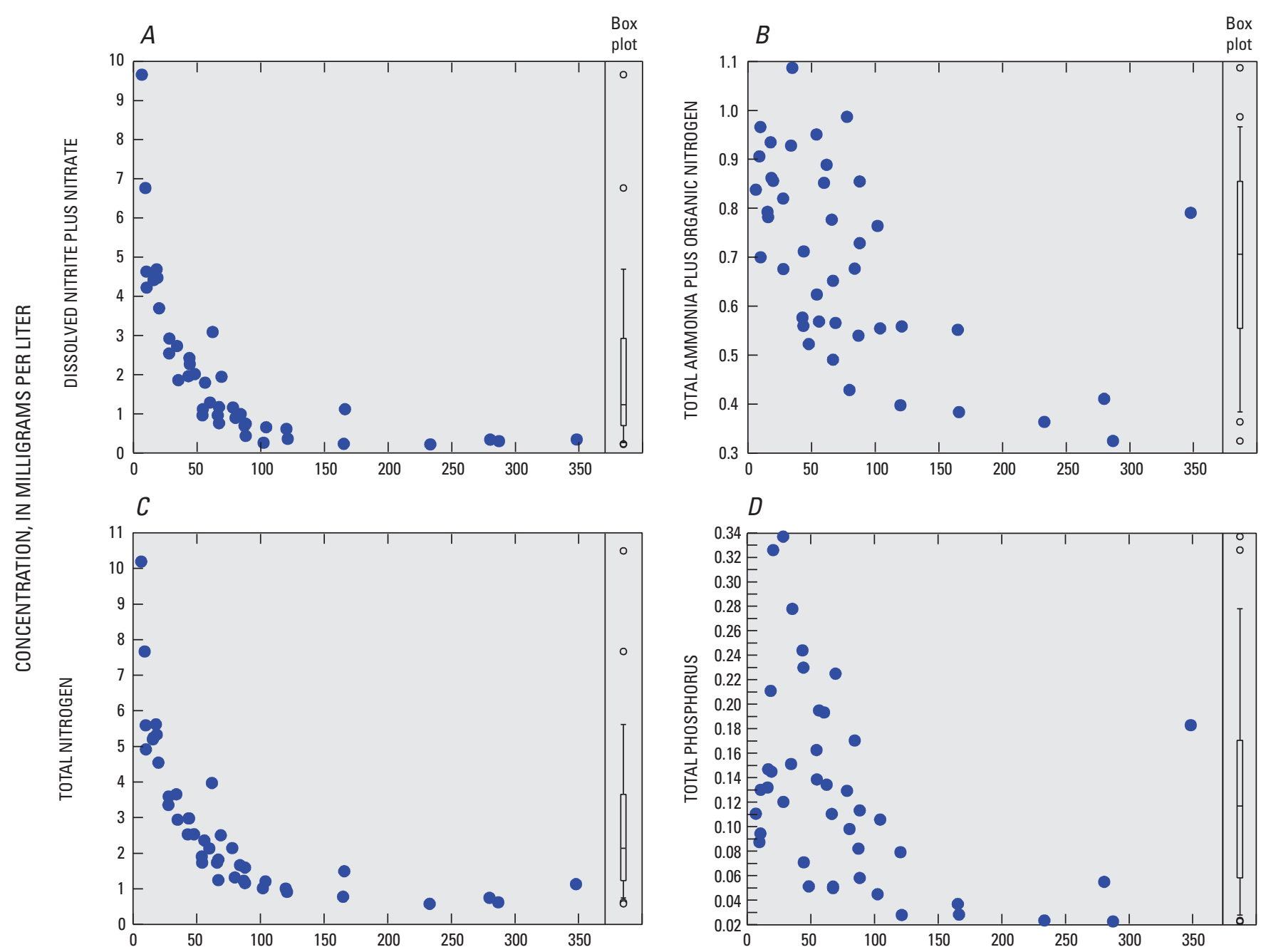

INSTANTANEOUS STREAMFLOW, IN CUBIC FEET PER SECOND
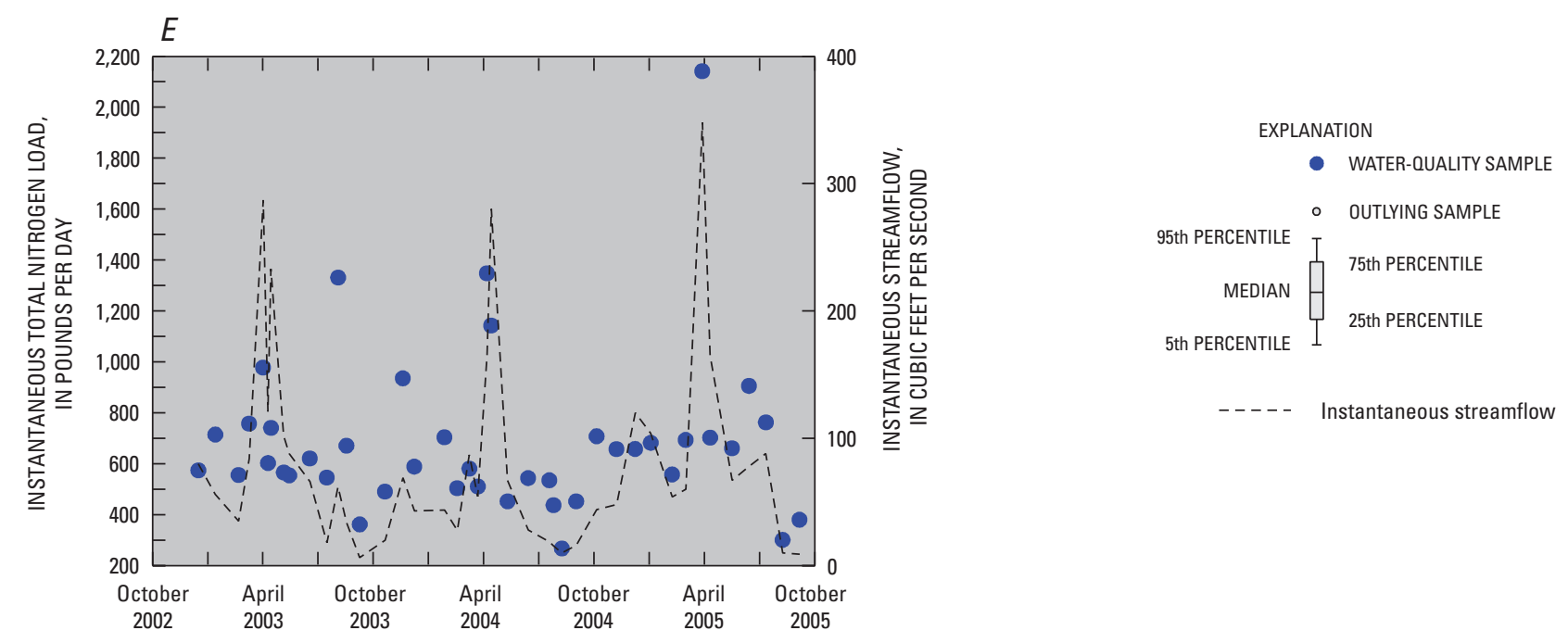

Figure 32. Distribution of $A$, Dissolved nitrite plus nitrate, $B$, Total ammonia plus organic nitrogen, $C$, Total nitrogen, $D$, Total phosphorus concentrations relative to streamflow, and $\mathrm{E}$, Instantaneous total nitrogen load relative to time for Otter River at Otter River, MA, station 01163200. (Refer to table 1 and figure 1 for station location.) 

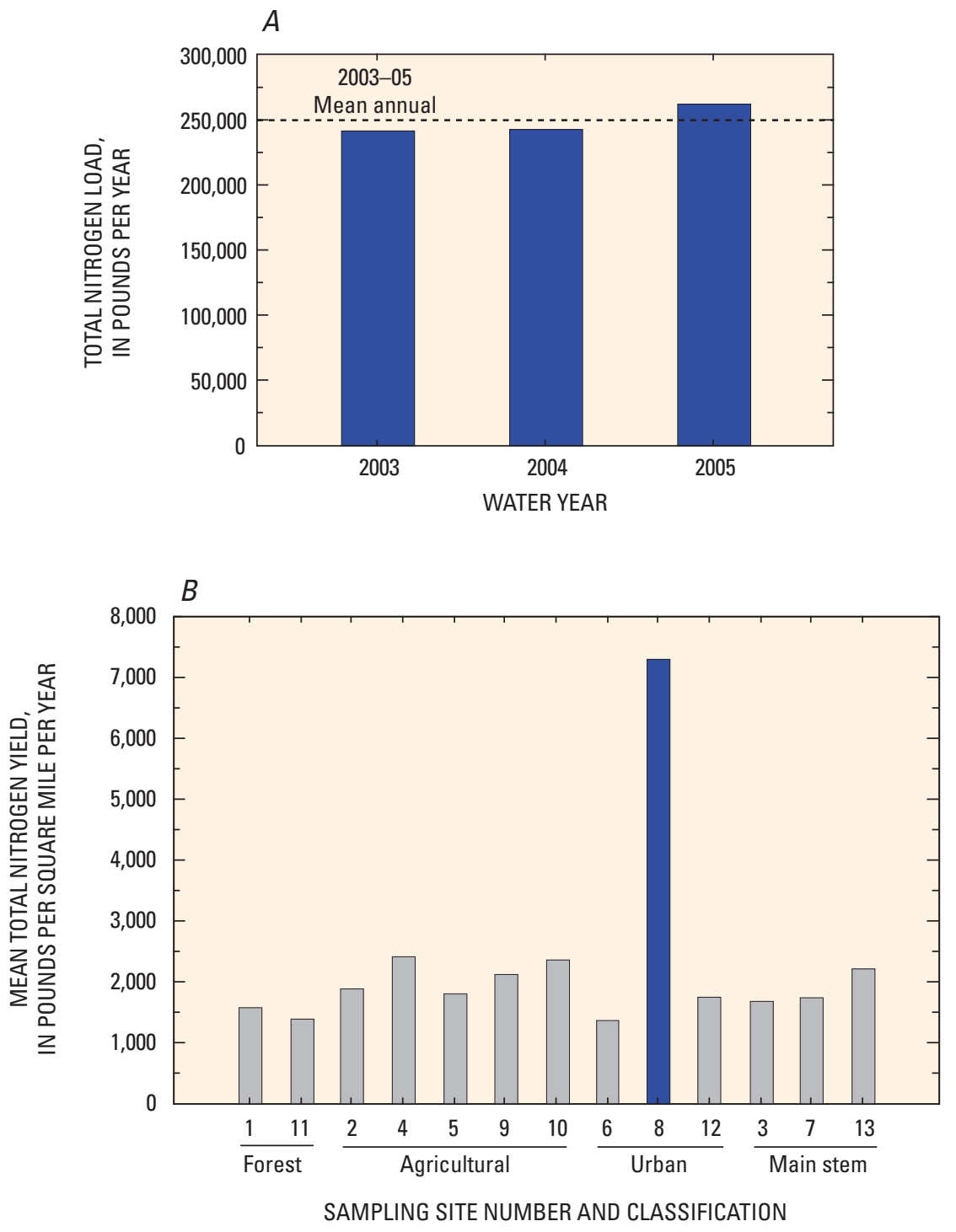

\section{EXPLANATION}

Otter River at Otter River, MA

All other river sampling sites

Figure 33. A, Total nitrogen load, by year, and $B$, Mean annual total nitrogen yield (2003-05) for Otter River at Otter River, MA, station 01163200, in relation to all other river sampling sites. (Refer to table 1 and figure 1 for site names and locations.) 


\section{North River at Shattuckville, MA, Station 01169000}

North River at Shattuckville, MA, represents an agricultural site in the study area. The contributing drainage basin upstream from the site encompasses about $89 \mathrm{mi}^{2}$ and is about 84 percent forested, 9 percent agriculture, 2 percent urban, and 5 percent wetlands and barren (fig. 34). Annual streamflow for 1980-2002 averaged 138,000 acre-feet, with considerable year-to-year variation (fig. 35A). Annual streamflow for the data-collection period for water years 2003-05 averaged 167,000 acre-feet (table 1). Streamflow was greater than the long-term mean for all 3 years of the study (fig. 35A).

Daily mean streamflows and the time distribution for 41 water samples are shown in figure $35 \mathrm{~B}$. The minimum streamflow at which water samples were collected was $22 \mathrm{ft}^{3} / \mathrm{s}$, and the maximum streamflow at which samples were collected was $2,030 \mathrm{ft}^{3} / \mathrm{s}$.

The minimum concentrations of dissolved oxygen was $8.0 \mathrm{mg} / \mathrm{L}$ and was within the Massachusetts water-quality criterion for dissolved oxygen (Massachusetts Department of Environmental Protection, 2005). Concentrations of selected water-quality constituents were plotted relative to streamflow (fig. 36). Concentrations of dissolved nitrite plus nitrate ranged from 0.082 to $1.35 \mathrm{mg} / \mathrm{L}$ and generally showed a slight variation (dilution) in relation to streamflow (fig. 36A). Total ammonia plus organic nitrogen ranged from an estimated 0.07 to $0.47 \mathrm{mg} / \mathrm{L}$ and generally showed at slight dilution with an increase in streamflow; however, an increase in total ammonia plus organic nitrogen was observed in samples collected at streamflows greater than about $500 \mathrm{ft}^{3} / \mathrm{s}$ (fig. 36B). An increase in concentration of suspended sediment relative to the other samples also was observed for the three samples collected at streamflows greater than $500 \mathrm{ft}^{3} / \mathrm{s}$. Concentrations of total nitrogen ranged from 0.25 to $1.7 \mathrm{mg} / \mathrm{L}$ (fig. 36C). Concentrations of total phosphorus ranged from 0.007 to $0.199 \mathrm{mg} / \mathrm{L}$ (fig. 36D). Concentrations of total phosphorus generally followed a similar pattern as concentrations of total ammonia plus organic nitrogen and likely were affected by an increase in concentrations of suspended sediment at greater streamflows. Instantaneous loads of total nitrogen ranged from 47 to $6,590 \mathrm{lb} / \mathrm{d}$ (fig. 36E). Ranges of concentrations or values for water-quality constituents not shown in figure 36 are listed below.

\begin{tabular}{lcccc}
\hline \multirow{2}{*}{$\begin{array}{c}\text { Water-quality } \\
\text { constituent }\end{array}$} & \multicolumn{4}{c}{$<$, less than; - } \\
\cline { 2 - 5 } & $\begin{array}{c}\text { Mini- } \\
\text { mum }\end{array}$ & Mean & Median & $\begin{array}{c}\text { Maxi- } \\
\text { mum }\end{array}$ \\
\hline Specific conductance & 47 & 107 & 105 & 212 \\
$\mathrm{pH}$ & 6.6 & 7.5 & 7.4 & 8.7 \\
Water temperature & .0 & 9.4 & 7.7 & 22.5 \\
Dissolved oxygen & 8.0 & 11.7 & 11.6 & 15.8 \\
Dissolved nitrite & $<.004$ & - & $<.004$ & .036 \\
Dissolved ammonia & $<.005$ & - & $<.005$ & .092 \\
Dissolved orthophos- & $<.01$ & - & $<.01$ & .13 \\
$\quad$ phate (WY 2003-04) & & & & .007 \\
Dissolved orthophos- & $<.003$ & - & .007 & .065 \\
$\quad$ phate (WY 2005) & 1 & 10 & 2 & 184 \\
Suspended sediment & 1 & & & \\
\hline
\end{tabular}

${ }^{\mathrm{a}}$ All constituents are reported as milligrams per liter except for specific conductance, which is reported as microsiemens per centimeter at 25 degrees Celsius; $\mathrm{pH}$, which is reported as standard units; and water temperature, which is reported as degrees Celsius; WY, water year.

The estimated load of total nitrogen varied among years during the study period (appendix A-1; fig. 37A). The mean annual load of total nitrogen was 194,000 lb/yr, with a ratio of the standard error of prediction to the mean load of 7.0 percent (table 2, fig. 37A). An estimated 43 percent of the total nitrogen load was transported during the spring (appendix A-2). The mean yield of total nitrogen $\left(2,180\left(\mathrm{lb} / \mathrm{mi}^{2}\right) / \mathrm{yr}\right)$ was greater than yield of total nitrogen at two of the agricultural sites in Vermont and less than the yield of total nitrogen at the other agricultural site in Massachusetts (fig. 37B). 
North River at Shattuckville, MA, Station 01169000

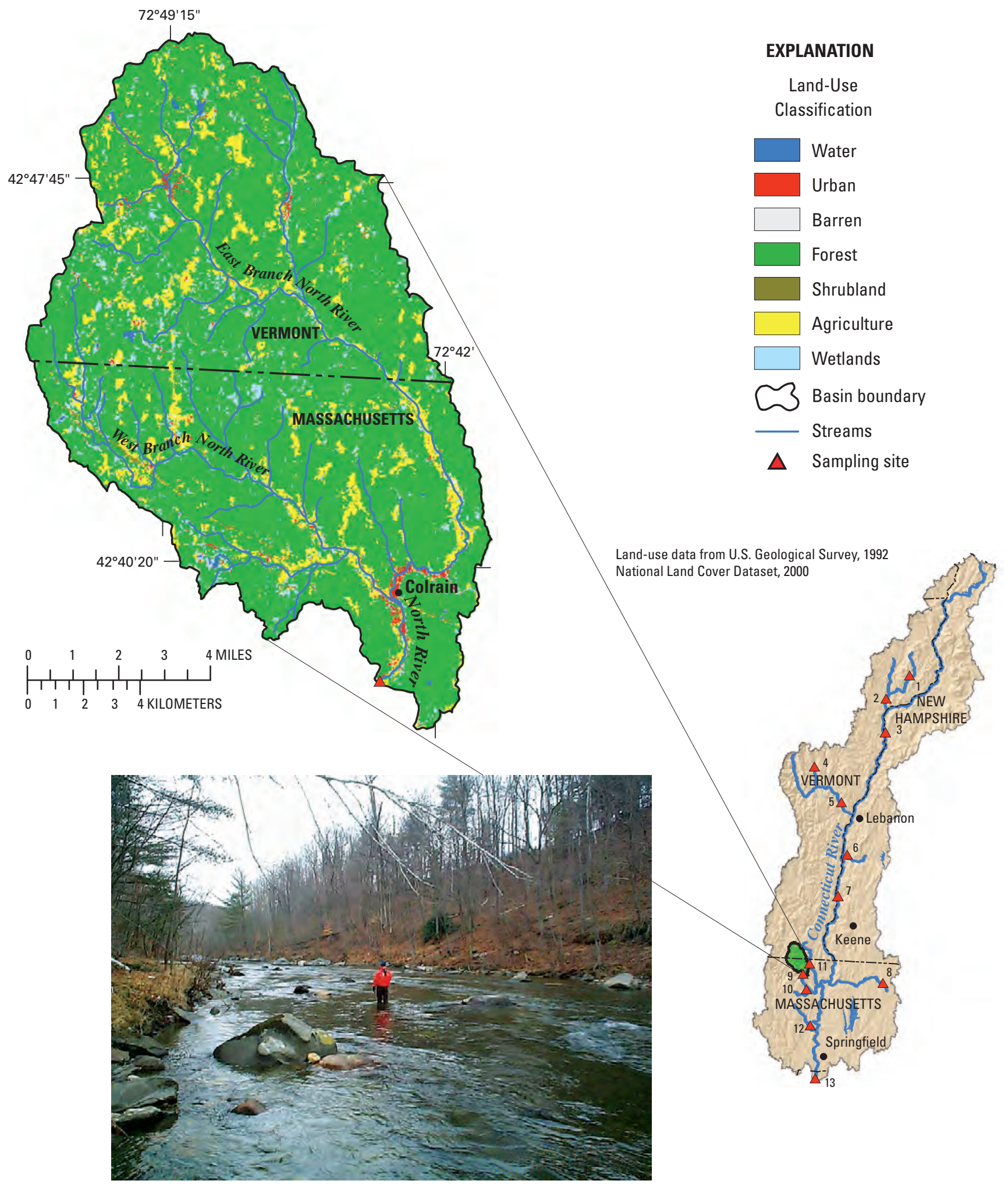

Photograph courtesy of Roy Socolow, U.S. Geological Survey

Figure 34. Location, land-use classification, and photograph of sampling site for North River at Shattuckville, MA, station 01169000. (Refer to table 1 and figure 1 for additional site information.) 

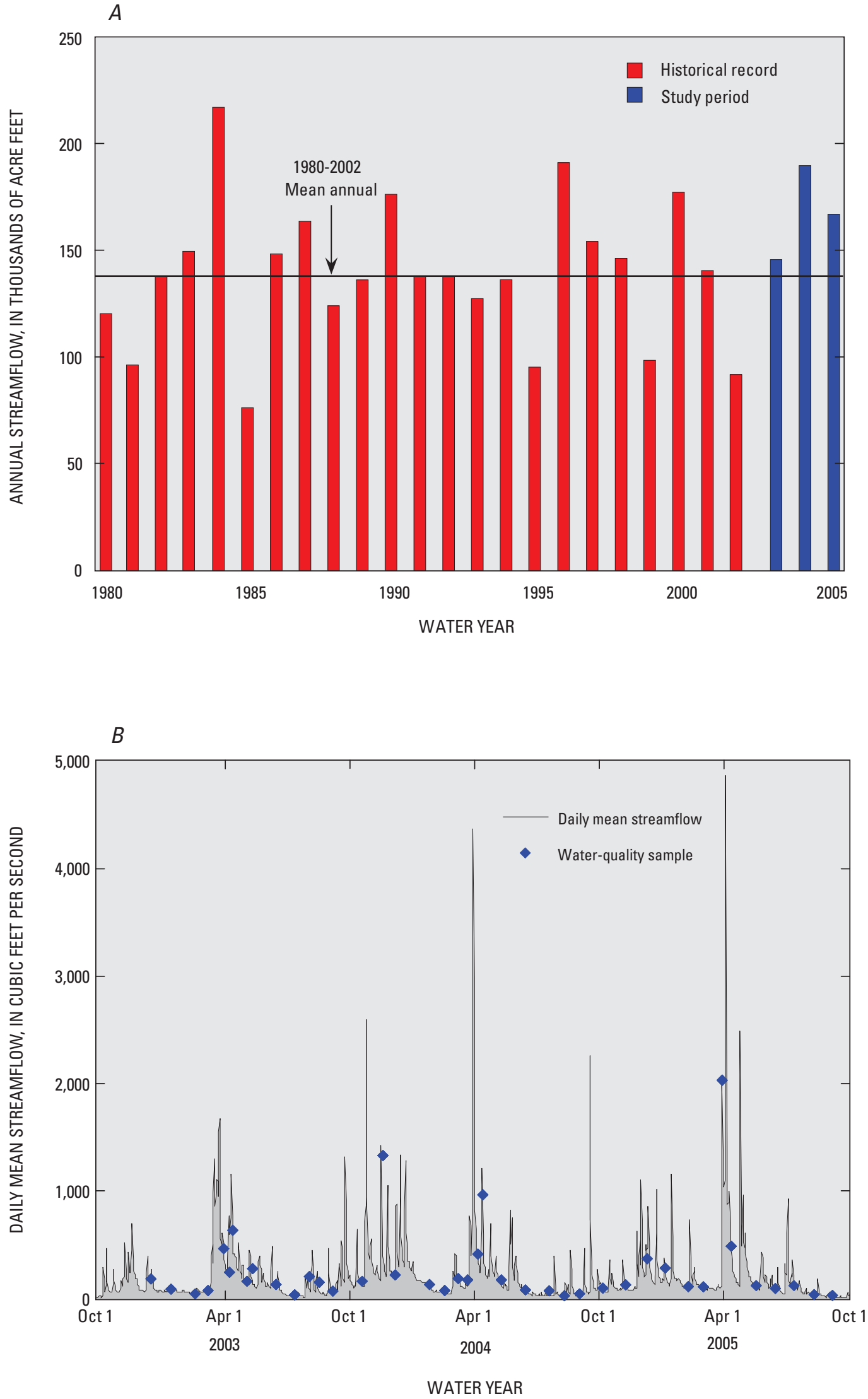

Figure 35. A, Historical and study-period annual streamflow, and $B$, Daily mean streamflow and time distribution of water-quality samples for North River at Shattuckville, MA, station 01169000. 

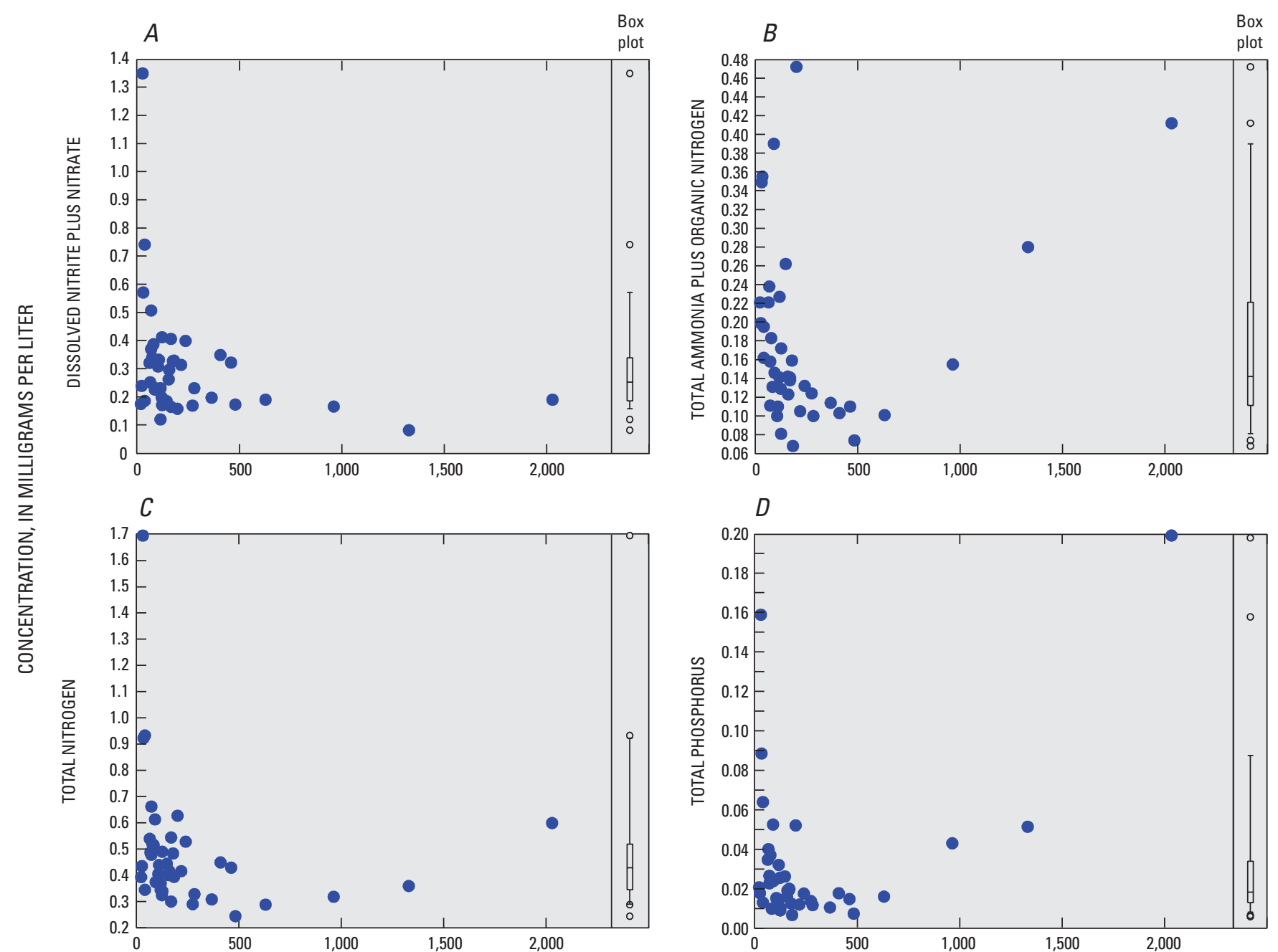

INSTANTANEOUS STREAMFLOW, IN CUBIC FEET PER SECOND
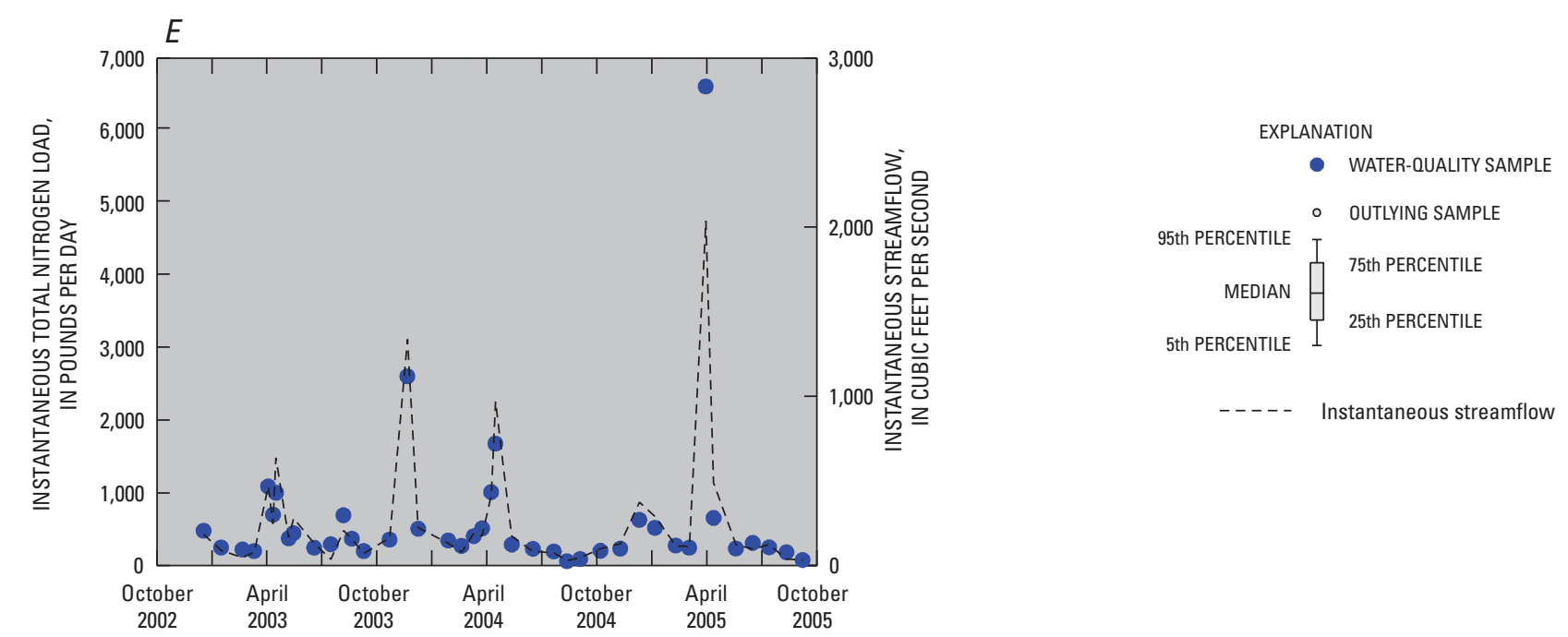

Figure 36. Distribution of $A$, Dissolved nitrite plus nitrate, $B$, Total ammonia plus organic nitrogen, $C$, Total nitrogen, $D$, Total phosphorus concentrations relative to streamflow, and $E$, Instantaneous total nitrogen load relative to time for North River at Shattuckville, MA, station 01169000. (Refer to table 1 and figure 1 for station location.) 

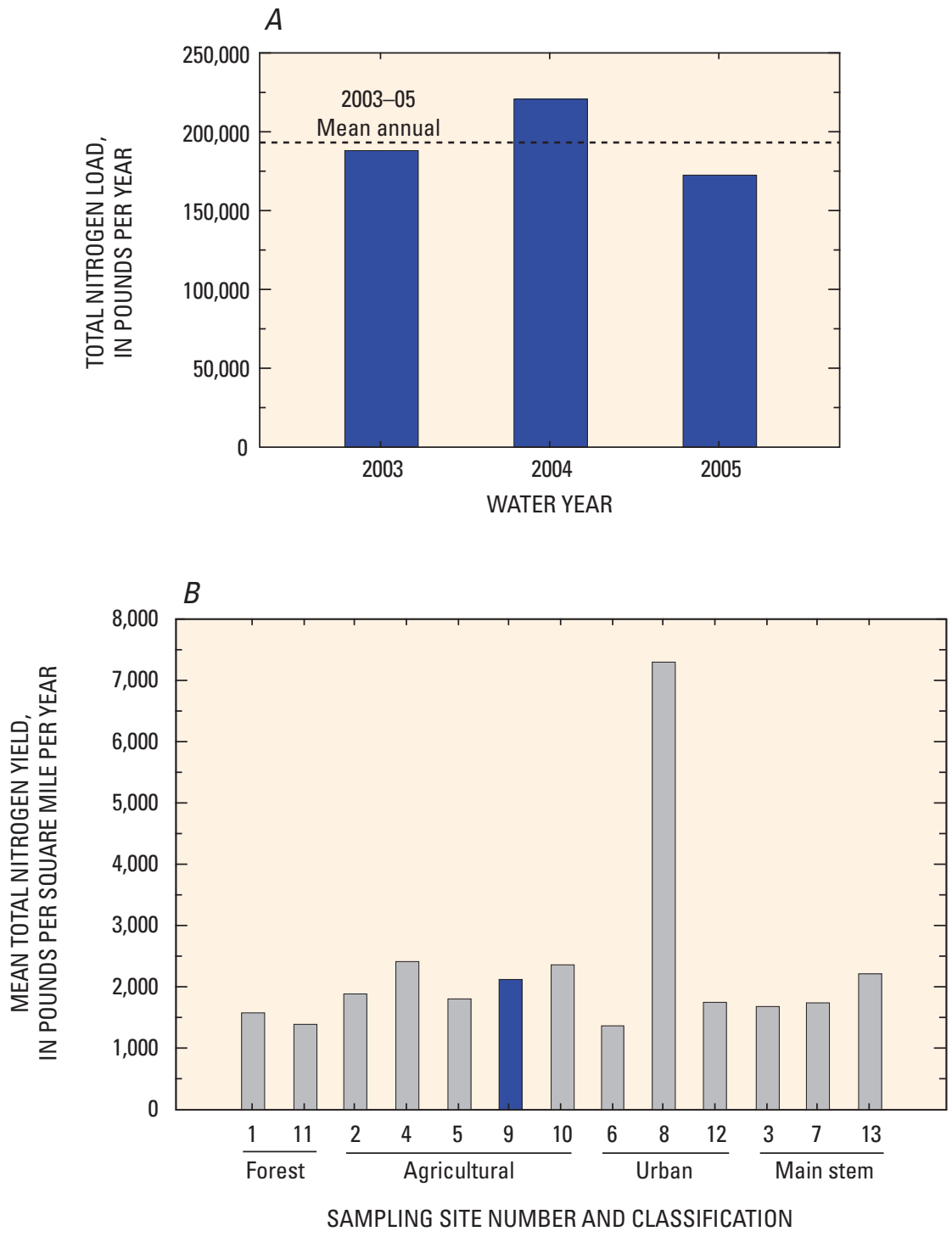

\section{EXPLANATION}

North River at Shattuckville, MA

All other river sampling sites

Figure 37. A, Total nitrogen load, by year, and $B$, Mean annual total nitrogen yield (2003-05) for North River at Shattuckville, MA, station 01169000 , in relation to all other river sampling sites. (Refer to table 1 and figure 1 for site names and locations.) 


\section{South River near Conway, MA, Station 01169900}

South River near Conway, MA, represents an agricultural site in the study area. The contributing drainage basin upstream from the site encompasses about $24 \mathrm{mi}^{2}$ and is about 81 percent forested, 10 percent agriculture, 4 percent urban, and 5 percent wetlands and barren (fig. 38). Annual streamflow for 1980-2002 averaged 37,100 acre-feet, with considerable year-to-year variation (fig. 39A). Annual streamflow for the data-collection period for water years 2003-05 averaged 48,100 acre-feet (table 1). Streamflow was greater than the long-term mean for all 3 years of the study (fig. 39A).

Daily mean streamflows and time distribution for 41 water-quality samples are shown in figure 39B. The minimum streamflow at which water samples were collected was $5 \mathrm{ft}^{3} / \mathrm{s}$, and the maximum streamflow at which samples were collected was $197 \mathrm{ft}^{3} / \mathrm{s}$.

The minimum concentration of dissolved oxygen was $7.9 \mathrm{mg} / \mathrm{L}$ and was within the Massachusetts water-quality criterion for dissolved oxygen (Massachusetts Department of Environmental Protection, 2005). Concentrations of selected water-quality constituents were plotted relative to streamflow (fig. 40). Concentrations of dissolved nitrite plus nitrate ranged from 0.175 to $0.635 \mathrm{mg} / \mathrm{L}$ and showed no relation to streamflow (fig. 40A). Total ammonia plus organic nitrogen ranged from an estimated 0.05 to $0.31 \mathrm{mg} / \mathrm{L}$ and showed no relation to streamflow (fig. 40B). The maximum concentration of $0.31 \mathrm{mg} / \mathrm{L}$ was in a sample collected at a streamflow of about $70 \mathrm{ft}^{3} / \mathrm{s}$ during a small increase in streamflow that resulted from rain in August 2003. The concentration of suspended sediment in this sample was one of the highest concentrations relative to other samples collected at the site. Concentrations of total nitrogen ranged from 0.26 to $1.0 \mathrm{mg} / \mathrm{L}$ (fig. 40C). Concentrations of total phosphorus ranged from an estimated 0.002 to $0.050 \mathrm{mg} / \mathrm{L}$ (fig. 40D). Instantaneous loads of total nitrogen ranged from 11 to $525 \mathrm{lb} / \mathrm{d}$ (fig. 40E). Ranges of concentrations or values for water-quality constituents not shown in figure 40 are listed below.

\begin{tabular}{lcccc}
\hline \multirow{2}{*}{$\begin{array}{c}\text { Water-quality } \\
\text { constituent }\end{array}$} & \multicolumn{4}{c}{$<$, less than; - , not calculated } \\
\cline { 2 - 5 } & $\begin{array}{c}\text { Mini- } \\
\text { mum }\end{array}$ & Mean & Median & $\begin{array}{c}\text { Maxi- } \\
\text { mum }\end{array}$ \\
\hline Specific conductance & 103 & 161 & 157 & 218 \\
$\mathrm{pH}$ & 6.7 & 7.4 & 7.4 & 8.5 \\
Water temperature & .0 & 9.2 & 7.4 & 24 \\
Dissolved oxygen & 7.9 & 11.2 & 11.3 & 14.4 \\
Dissolved nitrite & $<.004$ & - & $<.004$ & .123 \\
Dissolved ammonia & $<.005$ & - & $<.005$ & .020 \\
Dissolved orthophos- & $<.01$ & - & $<.01$ & $<.01$ \\
$\quad$ phate (WY 2003-04) & & & & \\
Dissolved orthophos- & $<.003$ & - & $<.003$ & $<.003$ \\
$\quad$ phate (WY 2005) & & & 2 & 49 \\
Suspended sediment & 1 & 5 & 2 & \\
\hline
\end{tabular}

${ }^{a}$ All constituents are reported as milligrams per liter except for specific conductance, which is reported as microsiemens per centimeter at 25 degrees Celsius; $\mathrm{pH}$, which is reported as standard units; and water temperature, which is reported as degrees Celsius; WY, water year.

The estimated load of total nitrogen varied among years during the study (appendix A-1; fig. 41A). The mean annual load of total nitrogen was $53,700 \mathrm{lb} / \mathrm{yr}$, with a ratio of the standard error of prediction to the mean load of 4.4 percent (table 2, fig. 41A). An estimated 31 and 39 percent of the total nitrogen load was transported during the winter and spring, respectively (appendix A-2). The mean yield of total nitrogen $\left(2,230\left(\mathrm{lb} / \mathrm{mi}^{2}\right) / \mathrm{yr}\right)$ was greater than at most of the other agricultural sites (fig. 41B). 
South River near Conway, MA, Station 01169900

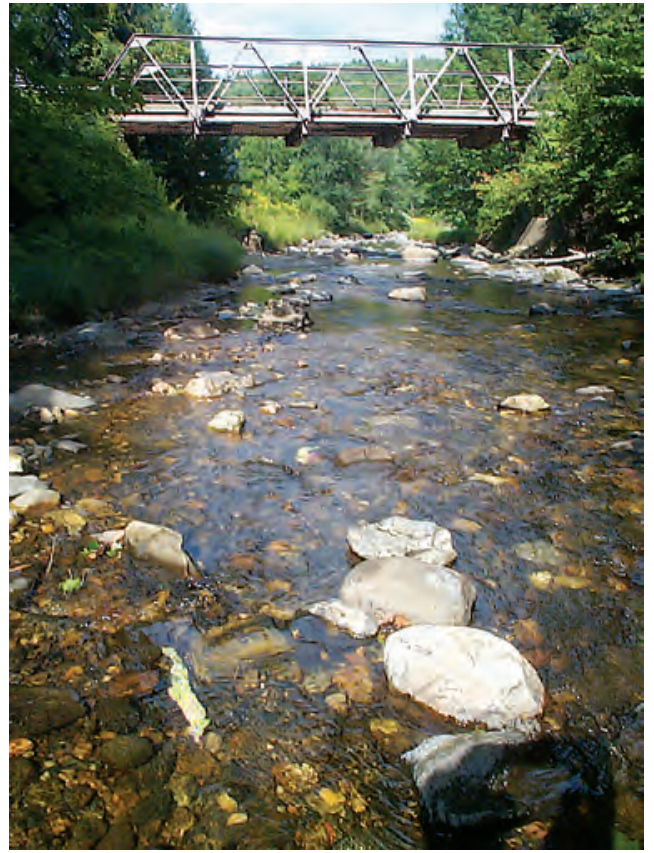

\title{
EXPLANATION
}

\author{
Land-Use \\ Classification
}

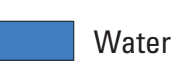

Urban

$\square$ Barren

Forest

Shrubland

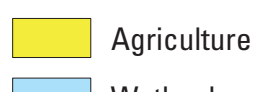

Wetlands

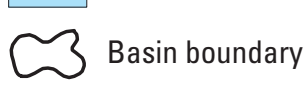

Streams

\ Sampling site

Photograph by Tim Driskell, U.S. Geological Survey

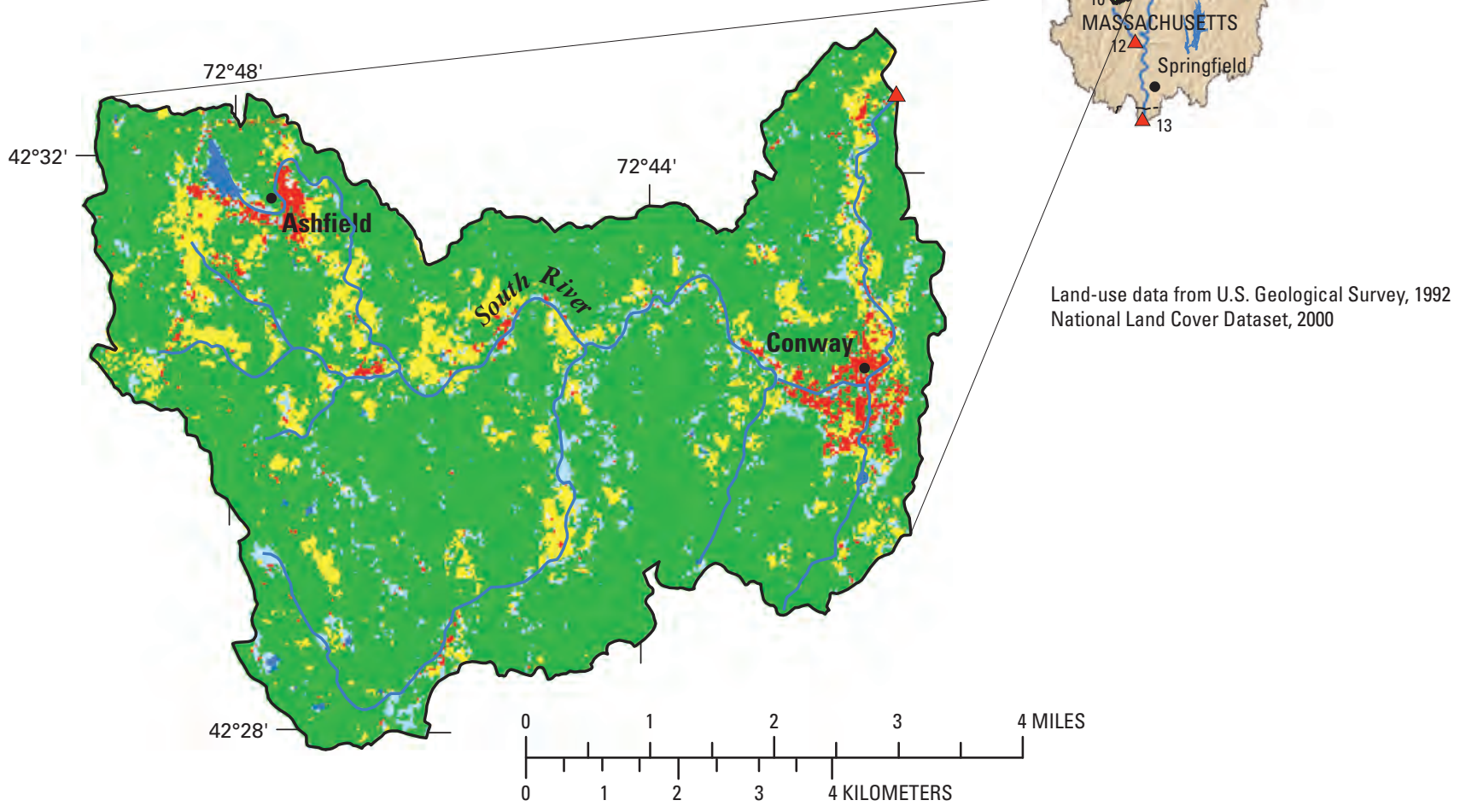

Figure 38. Location, land-use classification, and photograph of sampling site for South River near Conway, MA, station 01169900. (Refer to table 1 and figure 1 for additional site information.) 

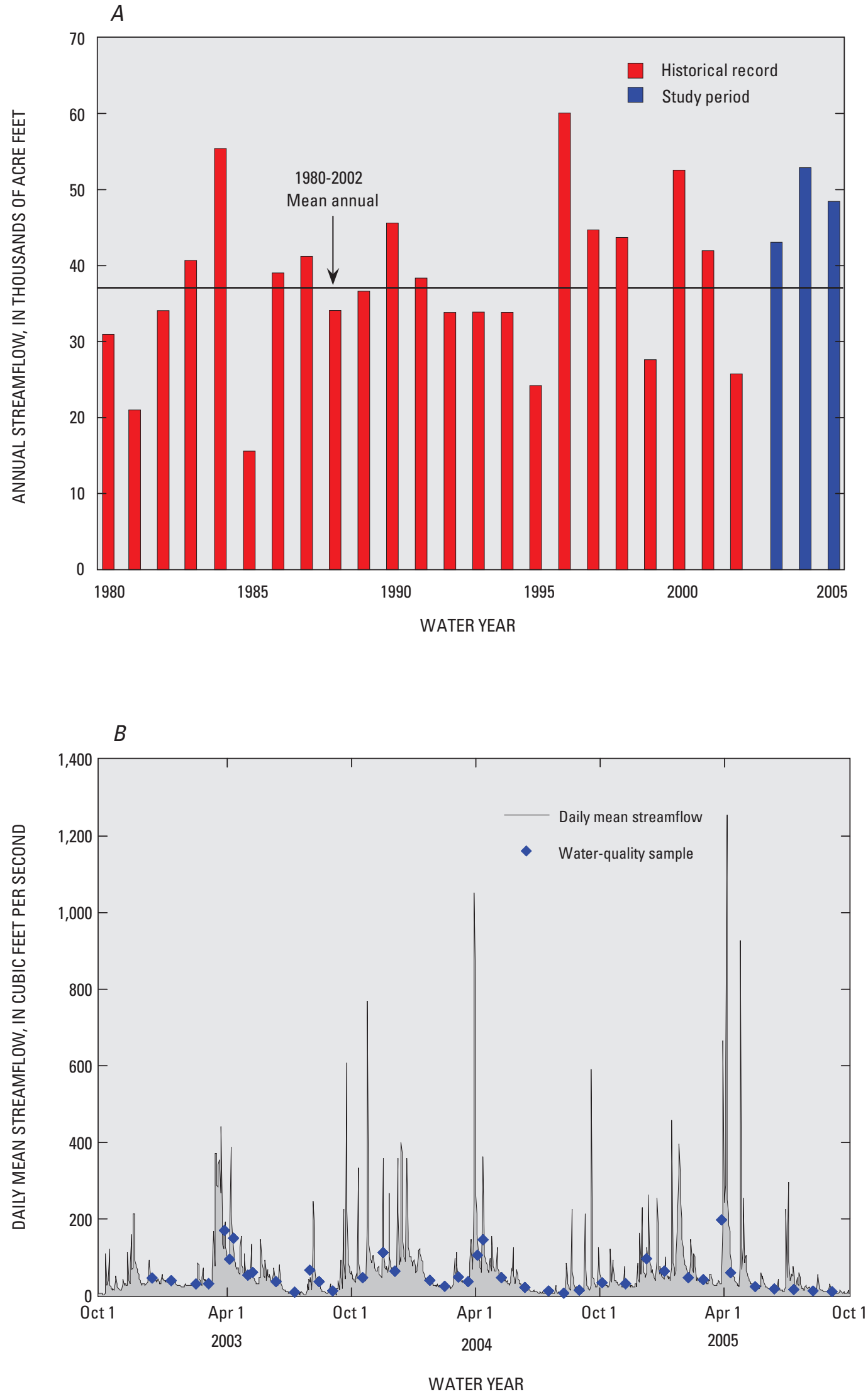

Figure 39. $A$, Historical and study-period annual streamflow, and $B$, Daily mean streamflow and time distribution of water-quality samples for South River near Conway, MA, station 01169900. 

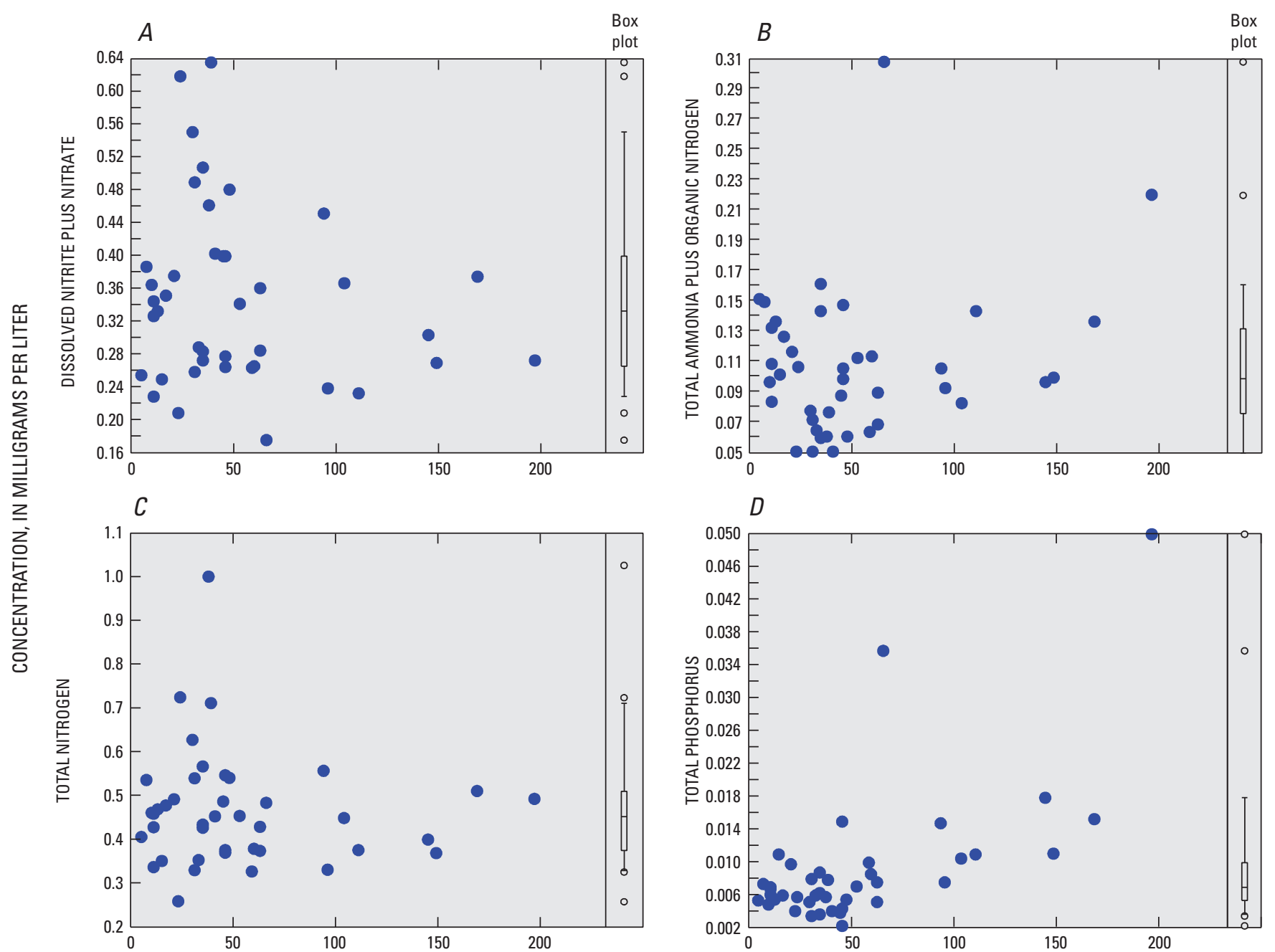

INSTANTANEOUS STREAMFLOW, IN CUBIC FEET PER SECOND
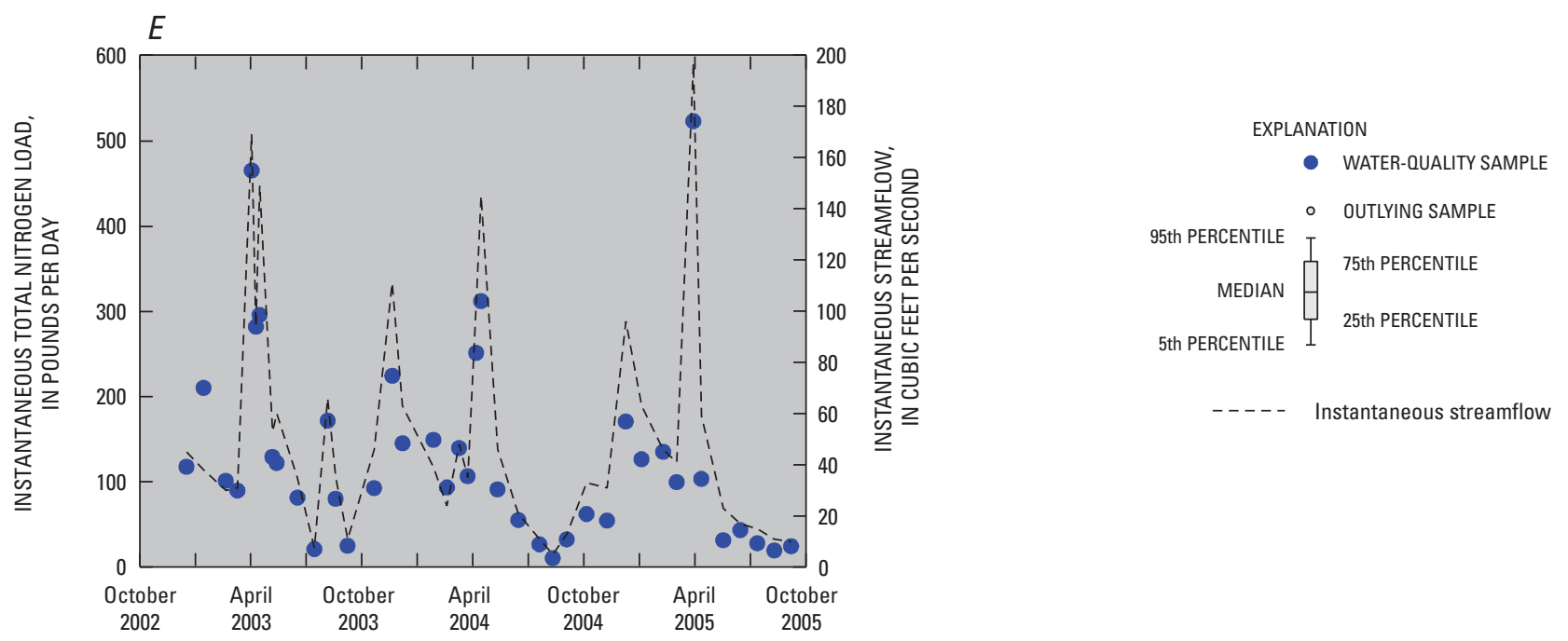

Figure 40. Distribution of $A$, Dissolved nitrite plus nitrate, $B$, Total ammonia plus organic nitrogen, $C$, Total nitrogen, $D$, Total phosphorus concentrations relative to streamflow, and $E$, Instantaneous total nitrogen load relative to time for South River near Conway, MA, station 01169900. (Refer to table 1 and figure 1 for station location.) 

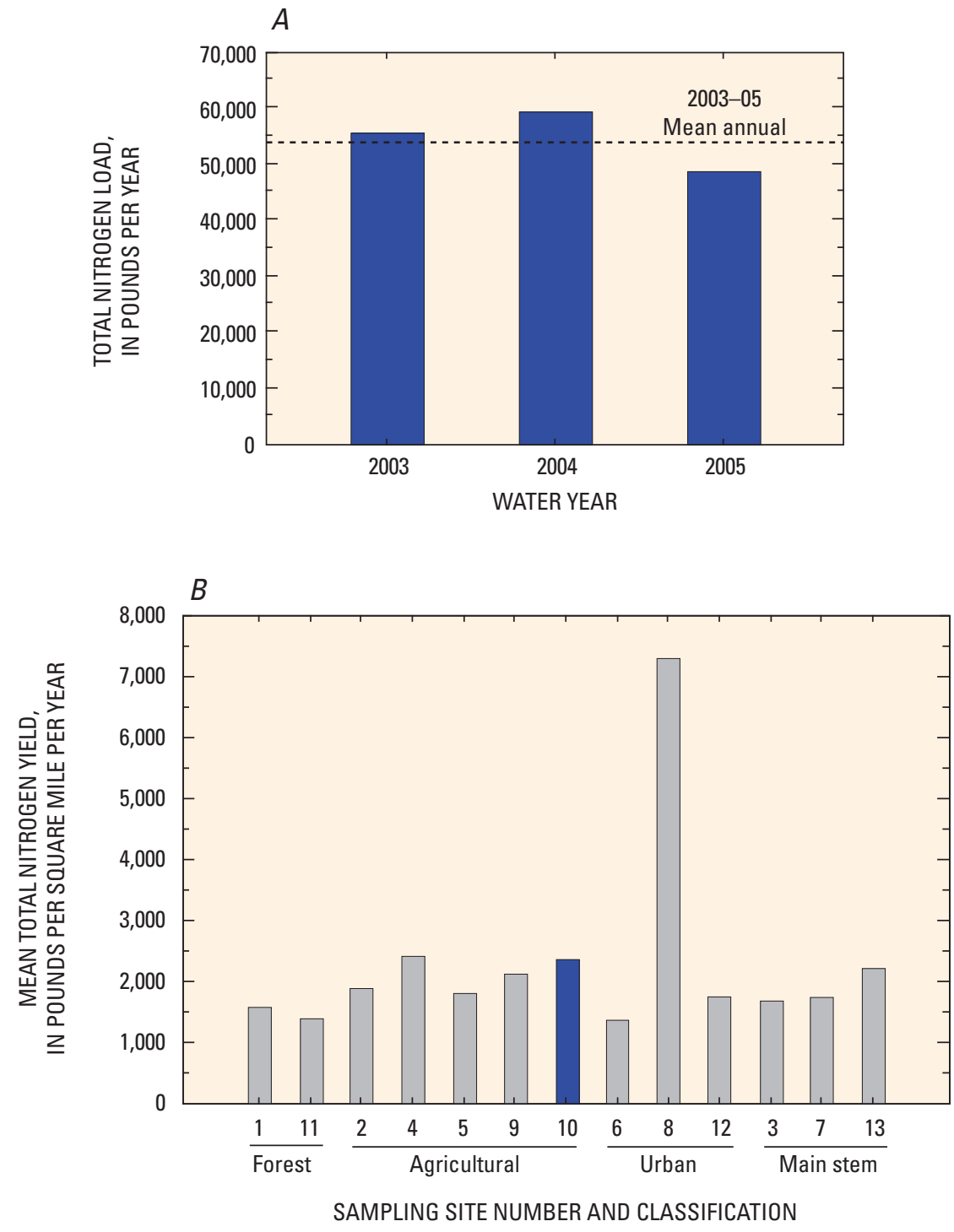

\section{EXPLANATION}

South River near Conway, MA

All other river sampling sites

Figure 41. A, Total nitrogen load, by year, and B, Mean annual total nitrogen yield (2003-05) for South River near Conway, MA, station 01169900, in relation to all other river sampling sites. (Refer to table 1 and figure 1 for site names and locations.) 


\section{Green River near Colrain, MA, Station 01170100}

Green River near Colrain, MA, represents a forested site in the study area. The contributing drainage basin upstream from the site encompasses about $41 \mathrm{mi}^{2}$ and is about 92 percent forested, 5 percent agriculture, 1 percent urban, and about 2 percent wetlands and barren (fig. 42). Annual streamflow for 1980-2002 averaged 61,400 acre-feet, with considerable year-to-year variation (fig. 43A). Annual streamflow for the data-collection period for water years 2003-05 averaged 74,400 acre-feet (table 1). Streamflow was greater than the long-term mean for all 3 years of the study (fig. 43A).

Daily mean streamflow and time distribution for 41 water-quality samples are shown in figure 43B. The minimum streamflow at which water samples were collected was $10 \mathrm{ft}^{3} / \mathrm{s}$, and the maximum streamflow at which samples were collected was $602 \mathrm{ft}^{3} / \mathrm{s}$.

The minimum concentration of dissolved oxygen was $8.4 \mathrm{mg} / \mathrm{L}$ and was within the Massachusetts water-quality criterion for dissolved oxygen (Massachusetts Department of Environmental Protection, 2005). Concentrations of selected water-quality constituents were plotted relative to streamflow (fig. 44). Concentrations of dissolved nitrite plus nitrate ranged from less than 0.016 to $0.201 \mathrm{mg} / \mathrm{L}$ and showed no relation to streamflow (fig. 44A). Total ammonia plus organic nitrogen ranged from an estimated 0.05 to $0.32 \mathrm{mg} / \mathrm{L}$ and also showed no relation to streamflow (fig. 44B). Concentrations of total nitrogen ranged from 0.06 to $0.46 \mathrm{mg} / \mathrm{L}$ (fig. 44C). Concentrations of total phosphorus ranged from an estimated 0.002 to $0.067 \mathrm{mg} / \mathrm{L}$ (fig. 44D). The maximum concentration of total phosphorus was observed at the second greatest streamflow at which samples were collected; this sample had the maximum concentration of suspended sediment $(61 \mathrm{mg} / \mathrm{L})$ relative to the other samples. Instantaneous loads of total nitrogen ranged from 5.5 to $1,240 \mathrm{lb} / \mathrm{d}$ (fig. 44E). Ranges of concentrations or values for water-quality constituents not shown in figure 44 are listed below.

\begin{tabular}{lcccc}
\hline \multirow{2}{*}{$\begin{array}{c}\text { Water-quality } \\
\text { constituent }\end{array}$} & \multicolumn{4}{c}{$<$, less than; - , not calculated } \\
\cline { 2 - 5 } & $\begin{array}{c}\text { Mini- } \\
\text { mum }\end{array}$ & Mean & Median & $\begin{array}{c}\text { Maxi- } \\
\text { mum }\end{array}$ \\
\hline Specific conductance & 51 & 84 & 88 & 128 \\
$\mathrm{pH}$ & 6.6 & 7.4 & 7.5 & 8.4 \\
Water temperature & .0 & 8.8 & 7.7 & 21.2 \\
Dissolved oxygen & 8.4 & 11.6 & 11.3 & 15.7 \\
Dissolved nitrite & $<.004$ & - & $<.004$ & .006 \\
Dissolved ammonia & $<.005$ & - & $<.005$ & .006 \\
Dissolved orthophos- & $<.01$ & - & $<.01$ & $<.01$ \\
$\quad$ phate (WY 2003-04) & & & & \\
Dissolved orthophos- & $<.003$ & - & $<.003$ & $<.003$ \\
$\quad$ phate (WY 2005) & & 4 & 1 & 61 \\
Suspended sediment & 1 & 4 & & \\
\hline
\end{tabular}

${ }^{a}$ All constituents are reported as milligrams per liter except for specific conductance, which is reported as microsiemens per centimeter at 25 degrees Celsius; $\mathrm{pH}$, which is reported as standard units; and water temperature, which is reported as degrees Celsius; WY, water year.

The estimated load of total nitrogen varied among years and was considerably less during the third year of the study (fig. 45A). The mean annual flow also was less during the third year of the study (appendix A-1). The mean annual load of total nitrogen was $49,100 \mathrm{lb} / \mathrm{yr}$, with a ratio of the standard error of prediction to the mean load of 10 percent (table 2, fig. 45A). This site had the greatest percentage of error relative to other sites. An estimated 47 percent of the total nitrogen load was transported during the spring (appendix A-2). The mean yield of total nitrogen $\left(1,190\left(\mathrm{lb} / \mathrm{mi}^{2}\right) / \mathrm{yr}\right)$ was less than all of the other study sites (fig. 45B). In general, water quality at this site typifies reference conditions for this area of the basin. Concentrations of total nitrogen and other water-quality constituents generally were low. 
Green River near Colrain, MA, Station 01170100

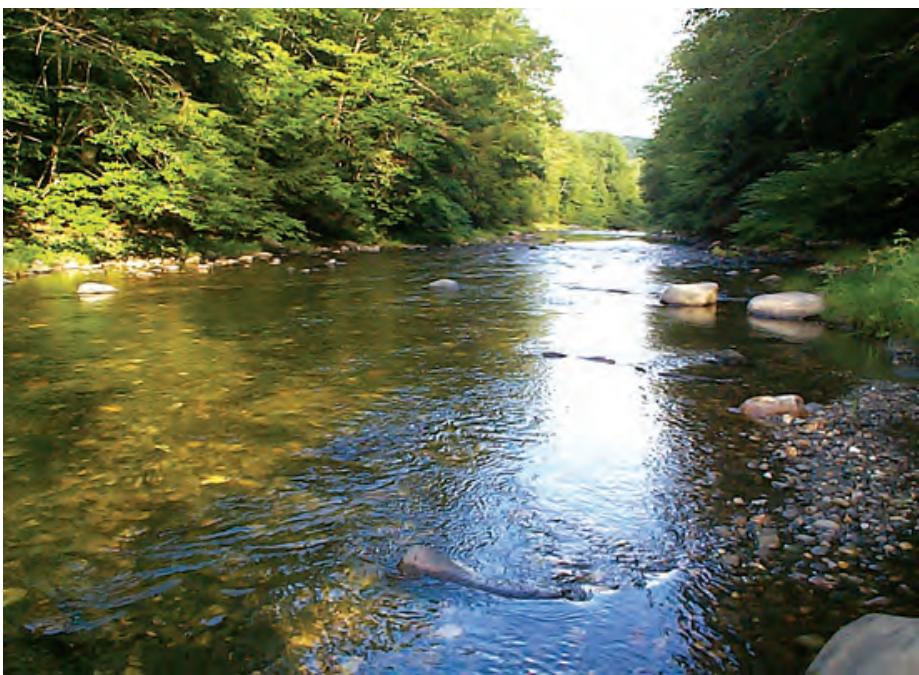
EXPLANATION
Land-Use
Classification

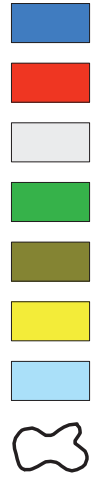
Water
Urban
Barren
Forest
Shrubland
Agriculture
Wetlands

Photograph by Tim Driskell, U.S. Geological Survey
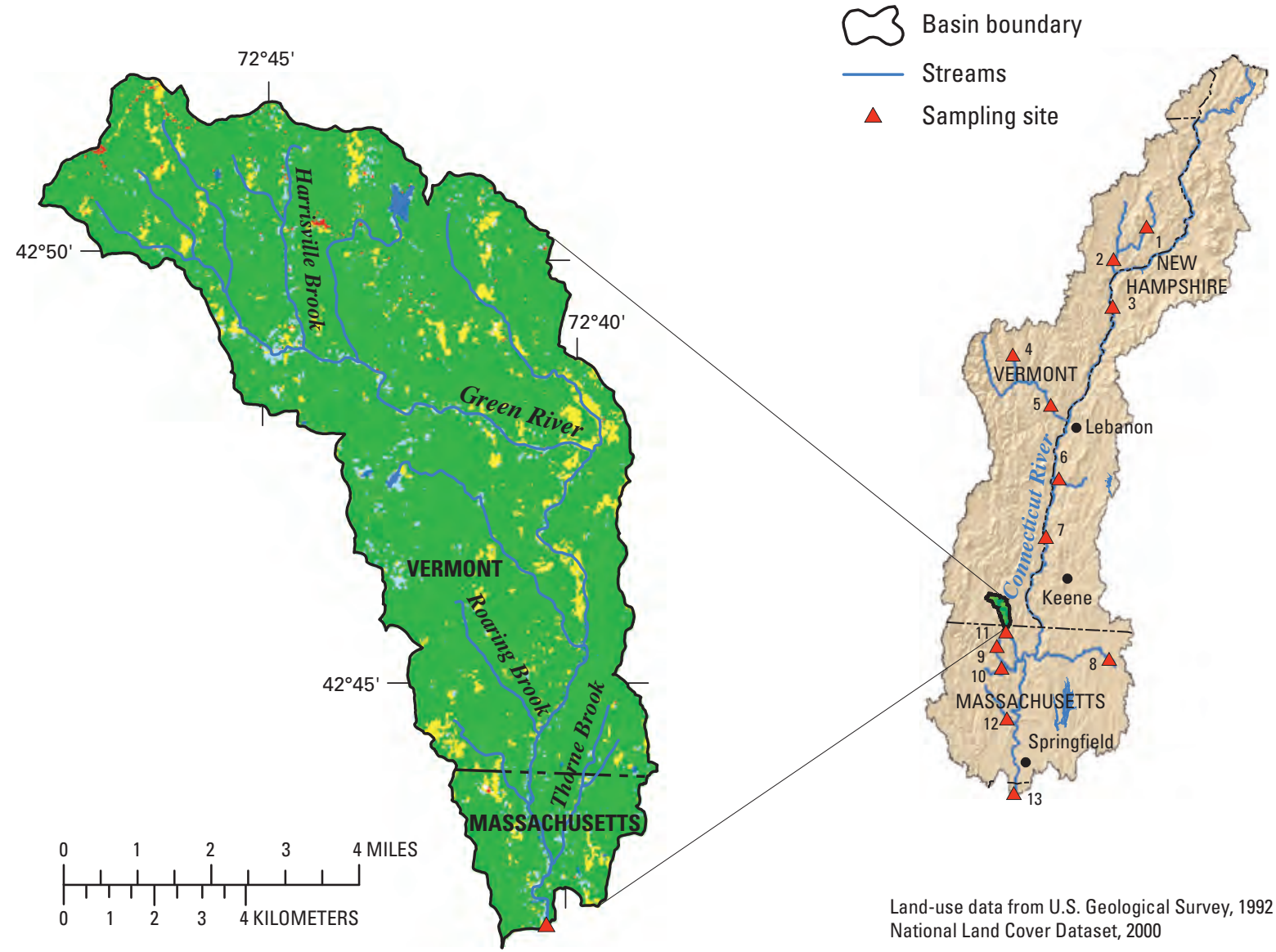

Figure 42. Location, land-use classification, and photograph of sampling site for Green River near Colrain, MA, station 01170100. (Refer to table 1 and figure 1 for additional site information.) 

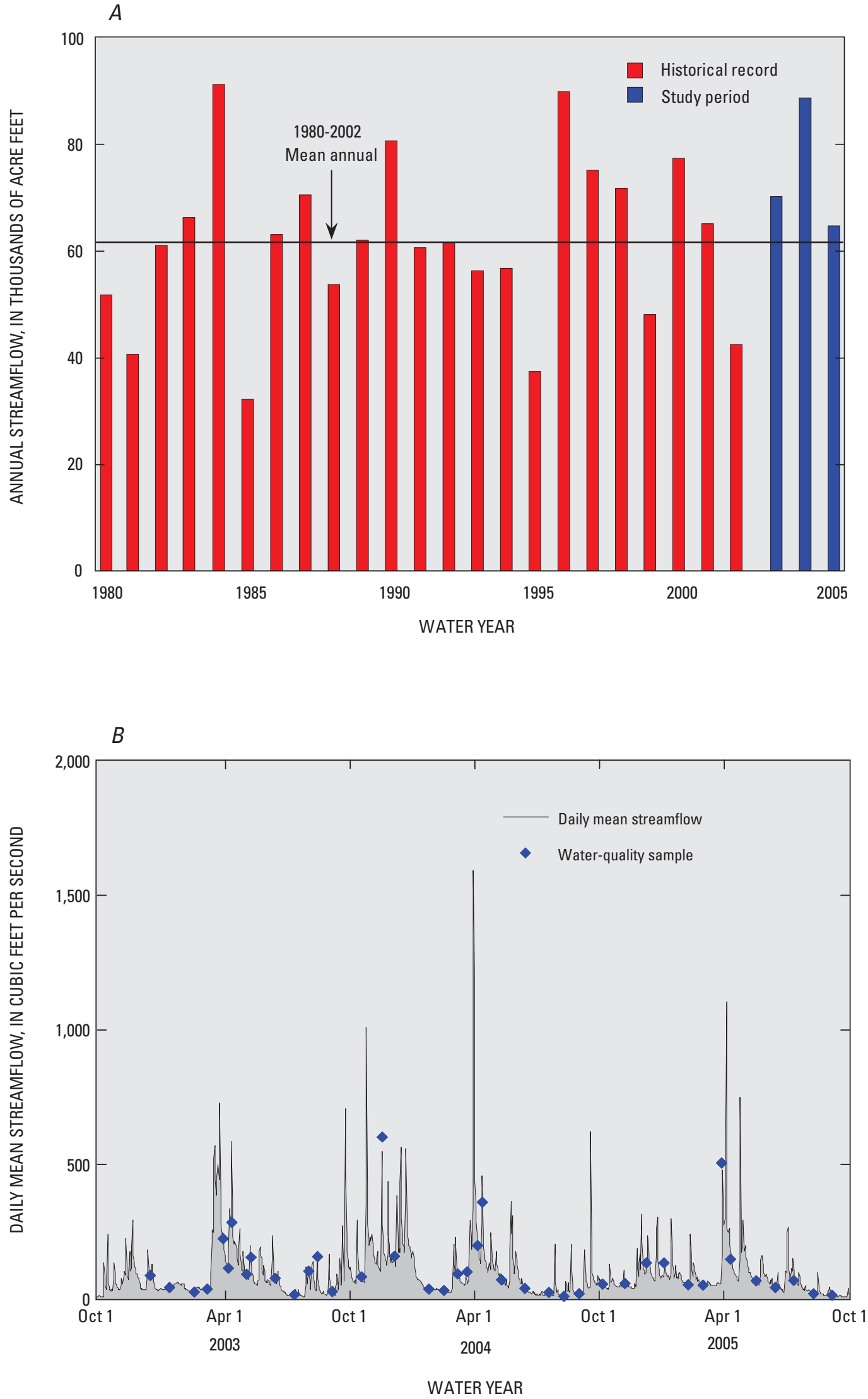

Figure 43. A, Historical and study-period annual streamflow, and $B$, Daily mean streamflow and time distribution of water-quality samples for Green River near Colrain, MA, station 01170100. 

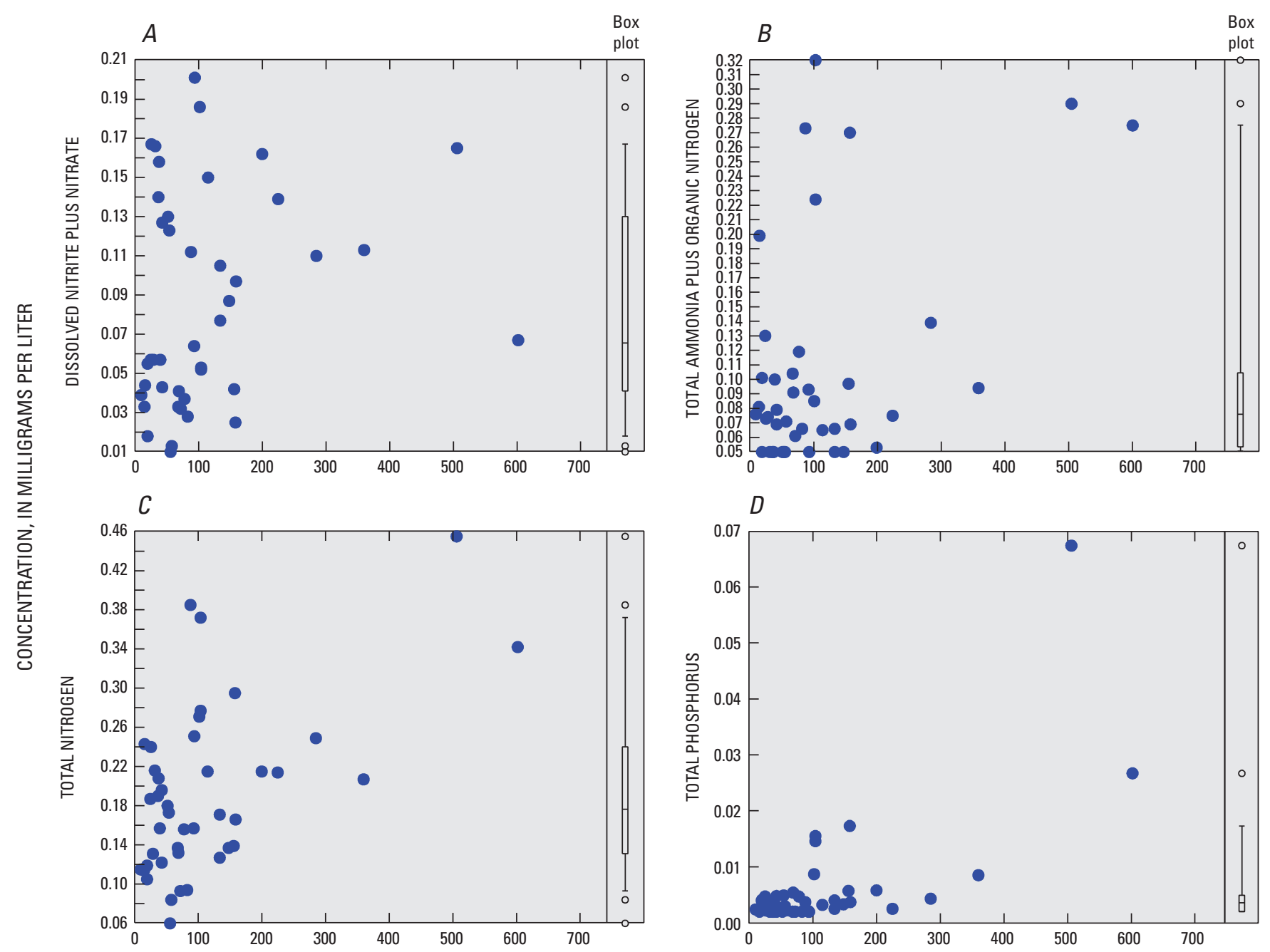

INSTANTANEOUS STREAMFLOW, IN CUBIC FEET PER SECOND
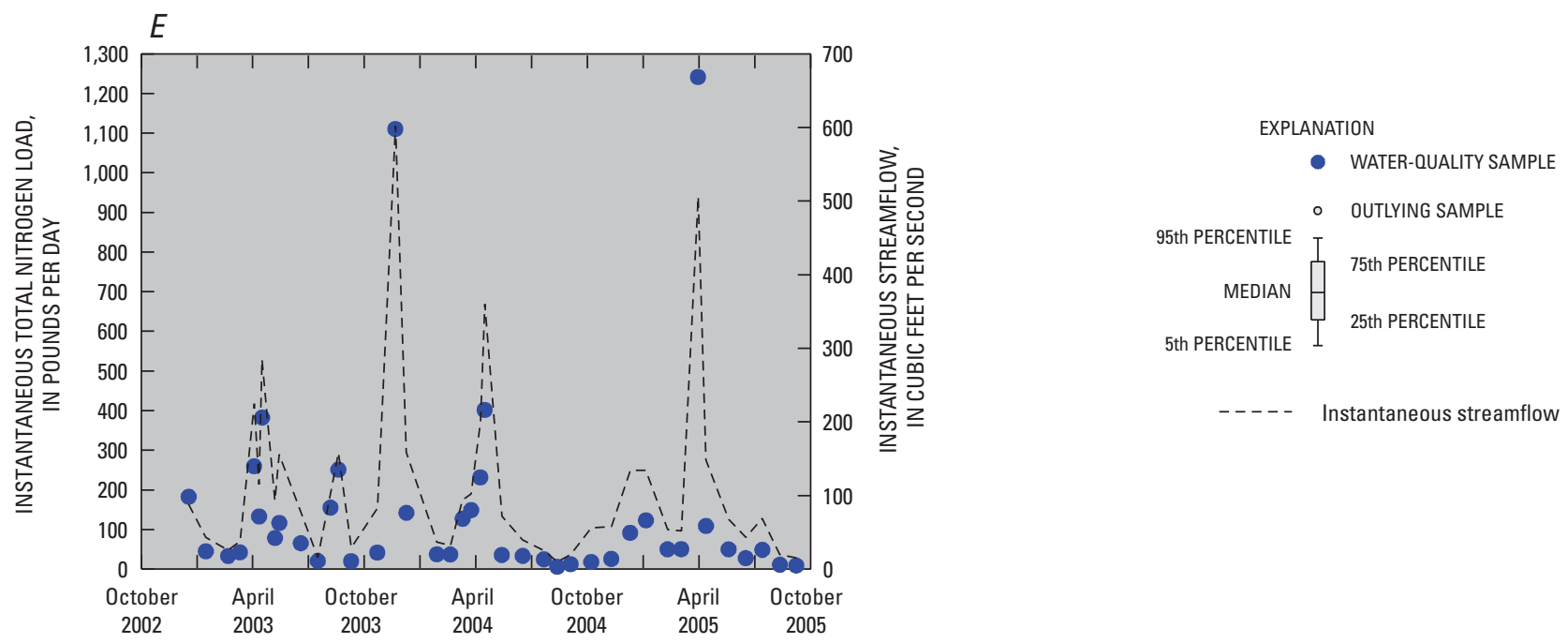

Figure 44. Distribution of $A$, Dissolved nitrite plus nitrate, $B$, Total ammonia plus organic nitrogen, $C$, Total nitrogen, $D$, Total phosphorus concentrations relative to streamflow, and $E$, Instantaneous total nitrogen load relative to time for Green River near Colrain, MA, station 01170100. (Refer to table 1 and figure 1 for station location.) 

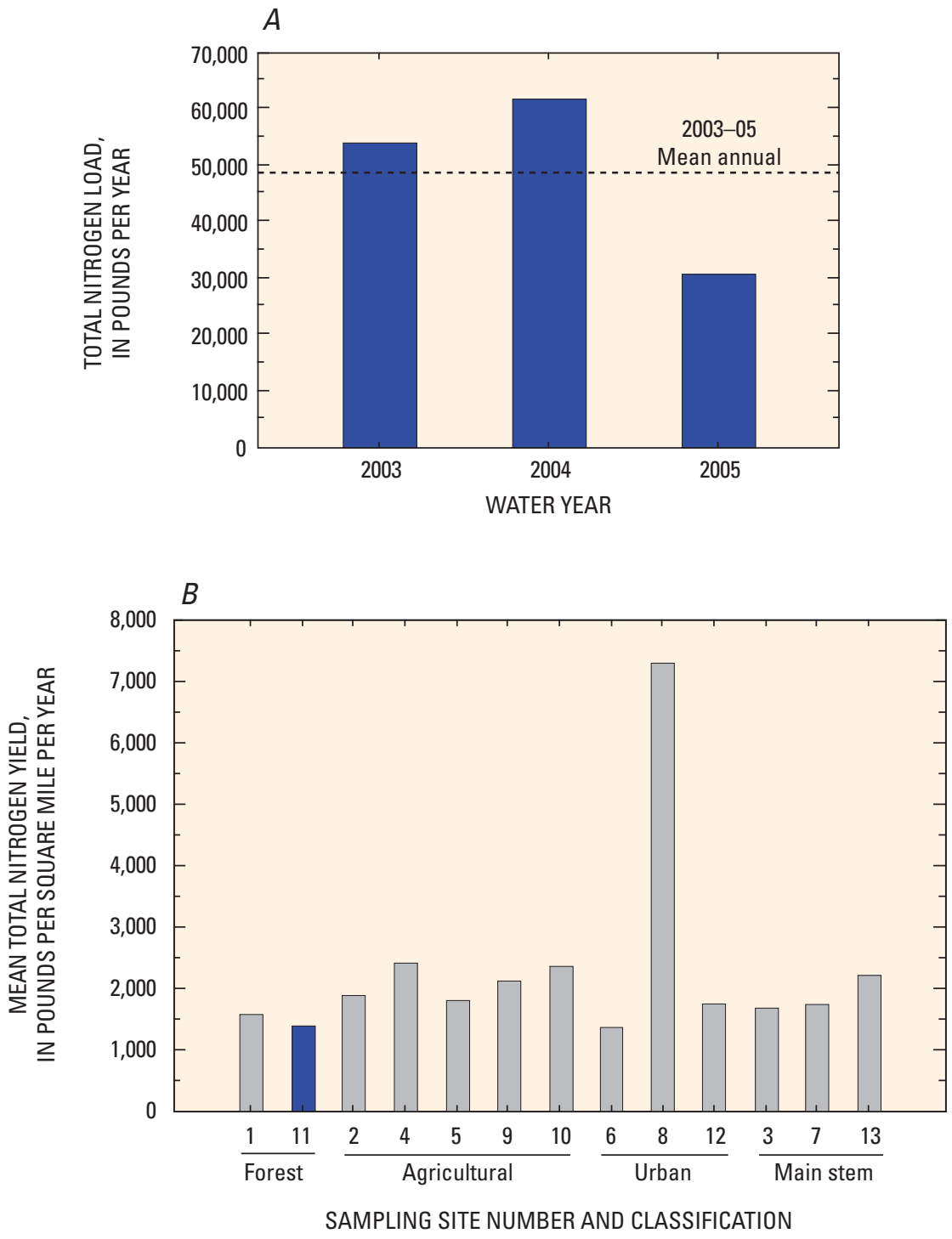

\section{EXPLANATION}

Green River near Colrain, MA

All other river sampling sites

Figure 45. A, Total nitrogen load, by year, and $B$, Mean annual total nitrogen yield (2003-05) for Green River near Colrain, MA, station 01170100, in relation to all other river sampling sites. (Refer to table 1 and figure 1 for site names and locations.) 


\section{Mill River at Northhampton, MA, Station 01171500}

Mill River at Northhampton, MA, represents an urban site in the study area. The contributing drainage basin upstream from this site encompasses about $54 \mathrm{mi}^{2}$ and is about 77 percent forested, 6 percent agriculture, 10 percent urban, and about 7 percent wetlands and barren (fig. 46). Annual streamflow for 1980-2002 averaged 73,000 acre-feet, with considerable year-to-year variation (fig. 47A). Annual streamflow for the data-collection period for water years 2003-05 averaged 88,400 acre-feet (table 1). Streamflow was greater than the long-term mean for all 3 years of the study (fig. 47A).

Daily mean streamflow and time distribution for 43 water samples are shown in figure 47B. The minimum streamflow at which water samples were collected was $12 \mathrm{ft}^{3} / \mathrm{s}$, and the maximum streamflow at which samples were collected was $512 \mathrm{ft}^{3} / \mathrm{s}$.

The minimum concentration of dissolved oxygen was $7.7 \mathrm{mg} / \mathrm{L}$ and was within the Massachusetts water-quality criterion for dissolved oxygen (Massachusetts Department of Environmental Protection, 2005). Concentrations of selected water-quality constituents were plotted relative to streamflow (fig. 48). Concentrations of dissolved nitrite plus nitrate ranged from less than 0.160 to $0.570 \mathrm{mg} / \mathrm{L}$ and, although some scatter was shown, there also was a slight dilution effect relative to streamflow (fig. 48A). Total ammonia plus organic nitrogen ranged from an estimated 0.07 to $0.31 \mathrm{mg} / \mathrm{L}$ and showed no relation to streamflow (fig. 48B). Concentrations of total nitrogen ranged from 0.29 to $0.68 \mathrm{mg} / \mathrm{L}$ and showed a pattern similar to dissolved nitrite plus nitrate (fig. 48C). Most of the total nitrogen at this site was in the form of dissolved nitrite plus nitrate. Concentrations of total phosphorus ranged from an estimated 0.006 to $0.026 \mathrm{mg} / \mathrm{L}$ (fig. 48D). The maximum concentration of total phosphorus was observed at the greatest streamflow at which samples were collected which was during snowmelt. This sample also had the greatest concentration of suspended sediment $(17 \mathrm{mg} / \mathrm{L})$ relative to the other samples. Instantaneous loads of total nitrogen ranged from 39 to $958 \mathrm{lb} / \mathrm{d}$ (fig. 48E). Ranges of concentrations or values for water-quality constituents not shown in figure 48 are listed below.

\begin{tabular}{lcccc}
\hline \multirow{2}{*}{$\begin{array}{c}\text { Water-quality } \\
\text { constituent }\end{array}$} & \multicolumn{4}{c}{$<$, less than; - , not calculated } \\
\cline { 2 - 5 } & $\begin{array}{c}\text { Mini- } \\
\text { mum }\end{array}$ & Mean & Median & $\begin{array}{c}\text { Maxi- } \\
\text { mum }\end{array}$ \\
\hline Specific conductance & 65 & 108 & 107 & 160 \\
pH & 6.3 & 7.2 & 7.2 & 8.0 \\
Water temperature & .0 & 10.1 & 8.3 & 22.6 \\
Dissolved oxygen & 7.7 & 11.2 & 11.2 & 15.1 \\
Dissolved nitrite & $<.004$ & - & $<.004$ & .087 \\
Dissolved ammonia & $<.005$ & & $<.005$ & .022 \\
Dissolved orthophos- & $<.01$ & - & $<.01$ & $<.01$ \\
$\quad$ phate (WY 2003-04) & & & & .003 \\
Dissolved orthophos- & $<.003$ & - & .003 & .007 \\
$\quad$ phate (WY 2005) & 1 & 3 & 2 & 17 \\
Suspended sediment & 1 & & \\
\hline
\end{tabular}

${ }^{a}$ All constituents are reported as milligrams per liter except for specific conductance, which is reported as microsiemens per centimeter at 25 degrees Celsius; $\mathrm{pH}$, which is reported as standard units; and water temperature, which is reported as degrees Celsius; WY, water year.

The estimated load of total nitrogen was similar during the first and second year of the study and less during the third year of the study (appendix A-1; fig. 49A). The mean annual load of total nitrogen was $95,400 \mathrm{lb} / \mathrm{yr}$, with a ratio of the standard error of prediction to the mean load of 3.0 percent (table 2, fig. 49A). An estimated 31 and 37 percent of the total nitrogen load was transported during the winter and spring, respectively (appendix A-2). The mean yield of total nitrogen $\left(1,770\left(\mathrm{lb} / \mathrm{mi}^{2}\right) / \mathrm{yr}\right)$ was similar to the yield of total nitrogen at other sites (fig. 49B). 
Mill River at Northampton, MA, Station 01171500

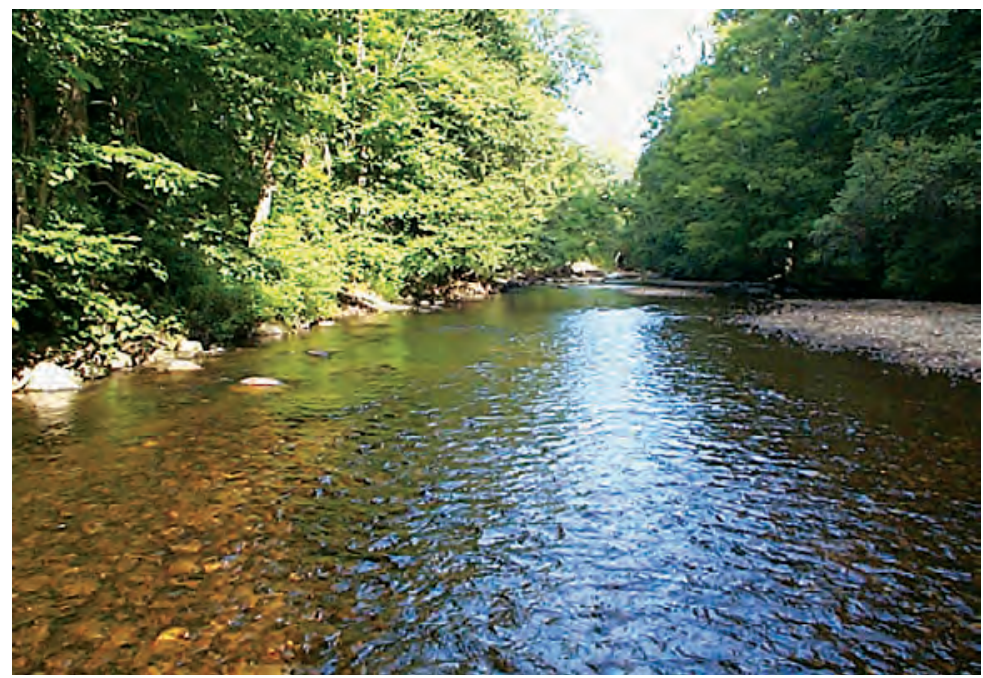

Photograph by Tim Driskell, U.S. Geological Survey
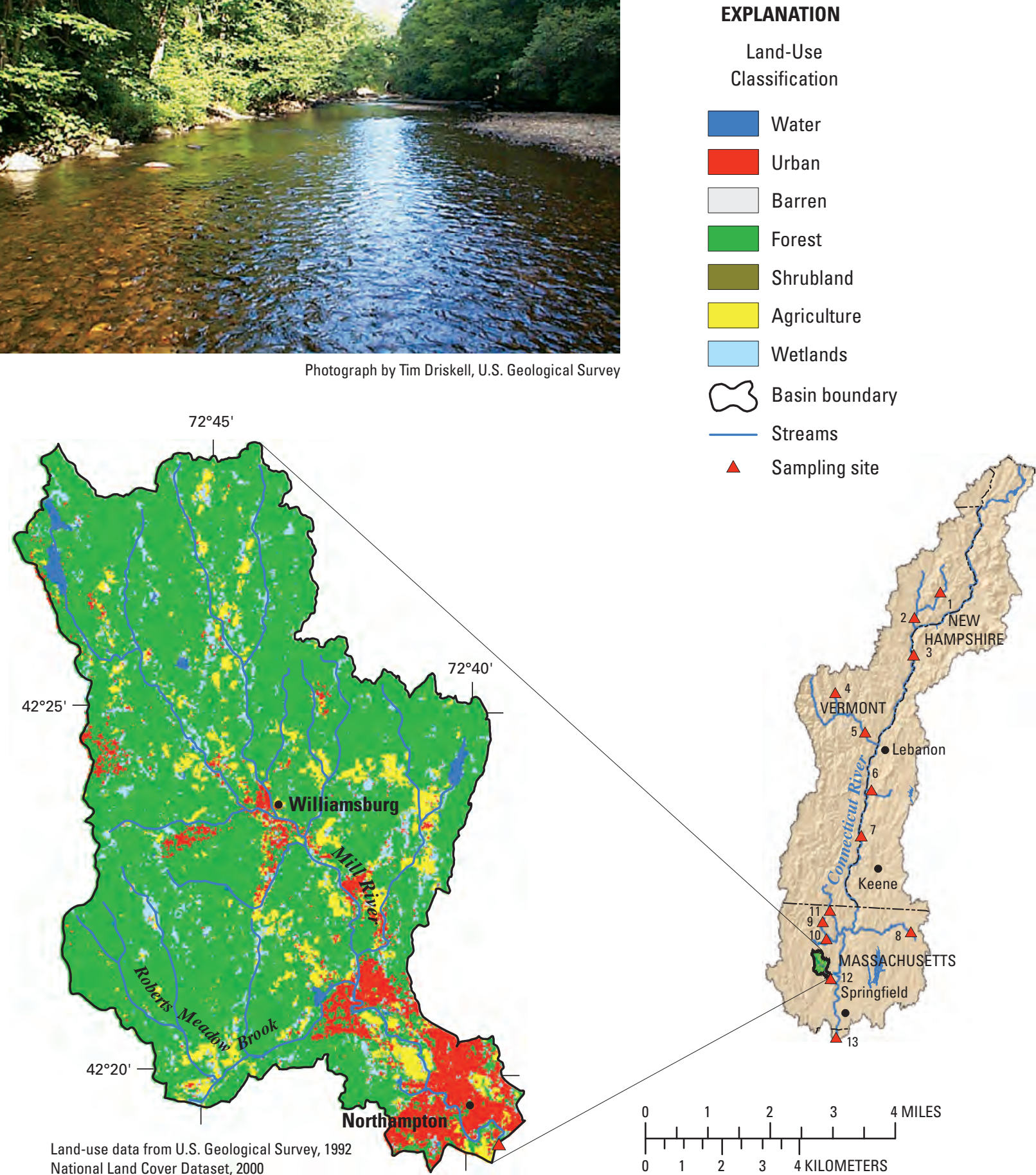

Figure 46. Location, land-use classification, and photograph of sampling site for Mill River at Northampton, MA, station 01171500. (Refer to table 1 and figure 1 for additional site information.) 

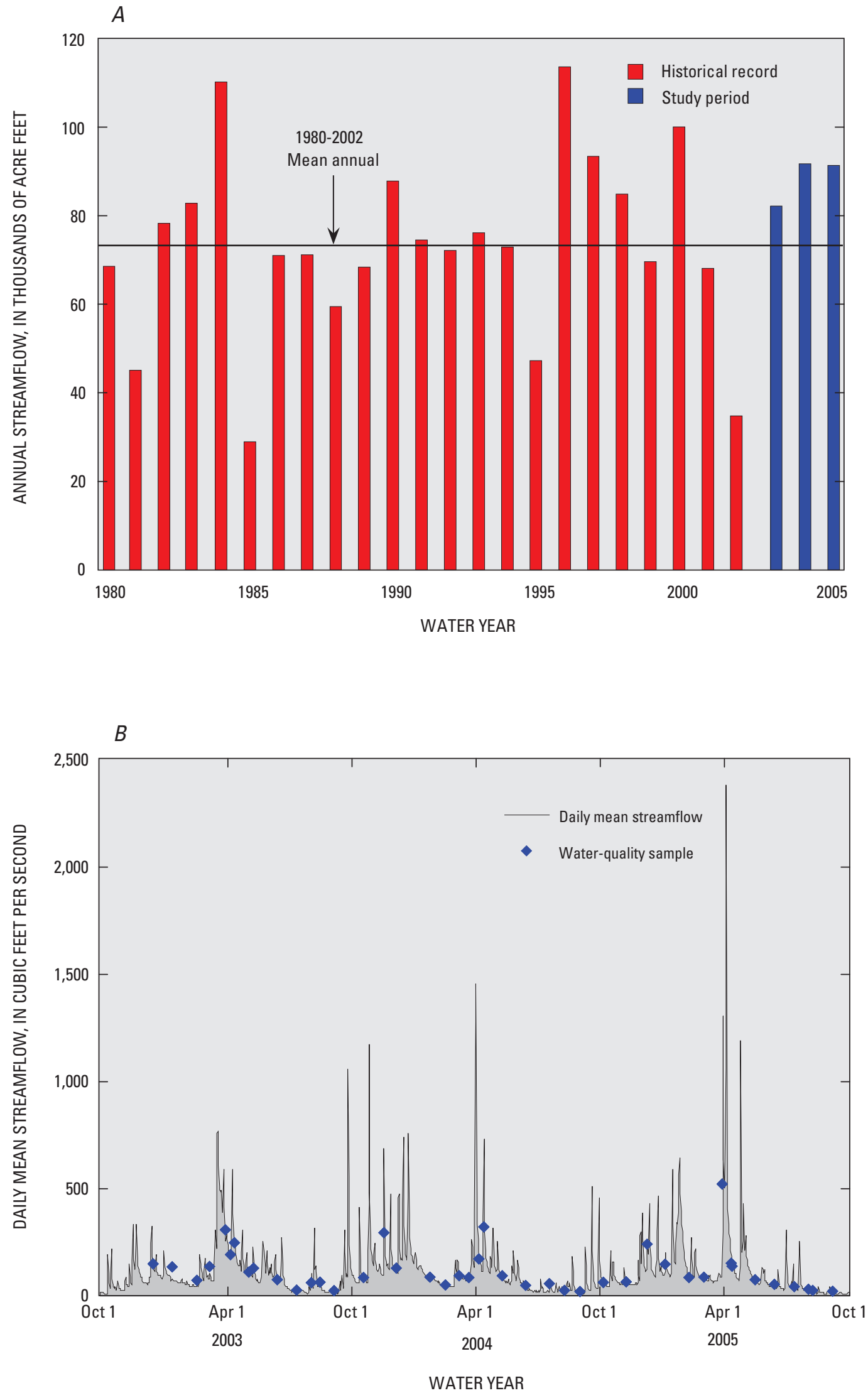

Figure 47. $A$, Historical and study-period annual streamflow, and $B$, Daily mean streamflow and time distribution of water-quality samples for Mill River at Northampton, MA, station 01171500. 

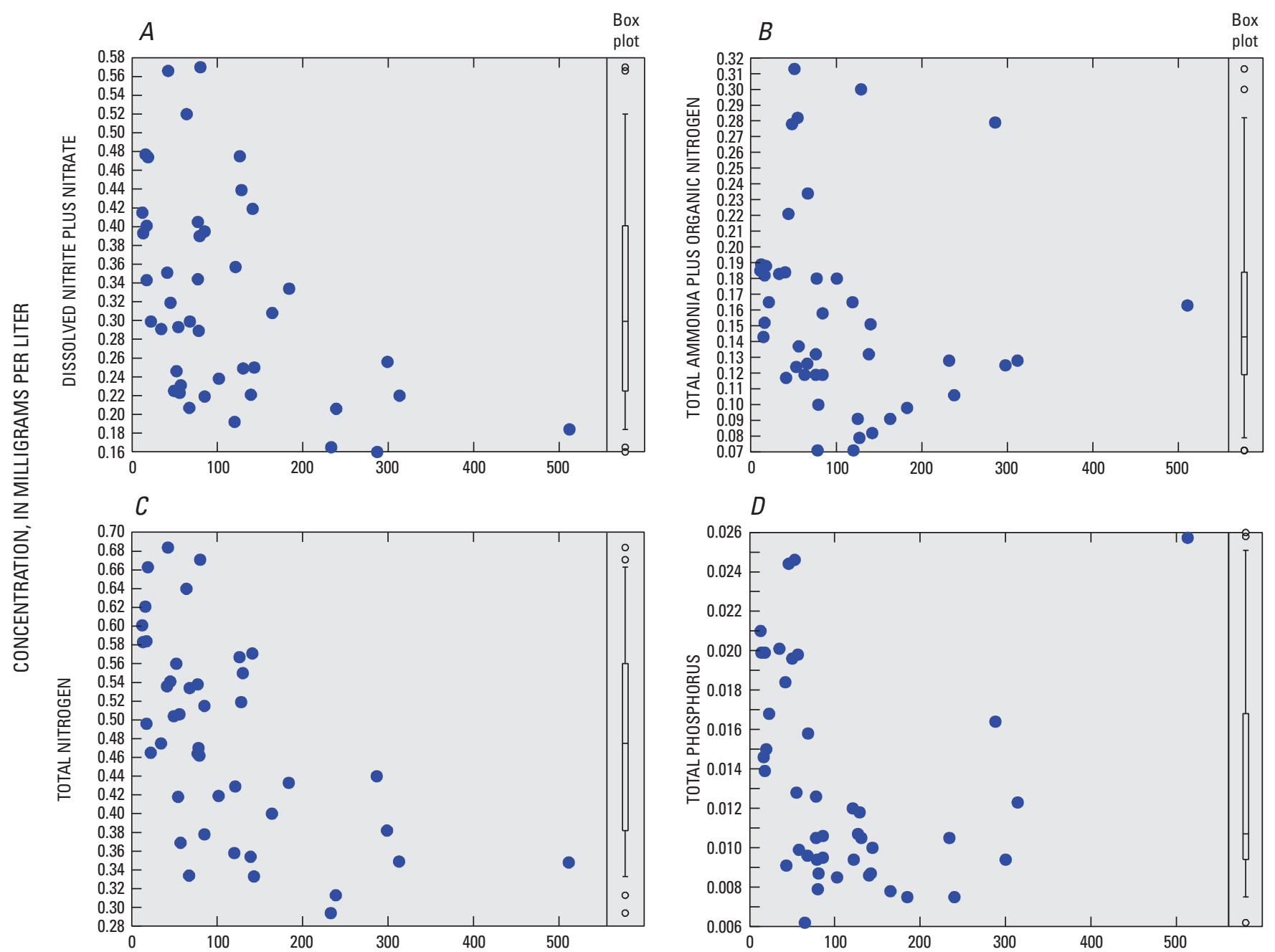

INSTANTANEOUS STREAMFLOW, IN CUBIC FEET PER SECOND
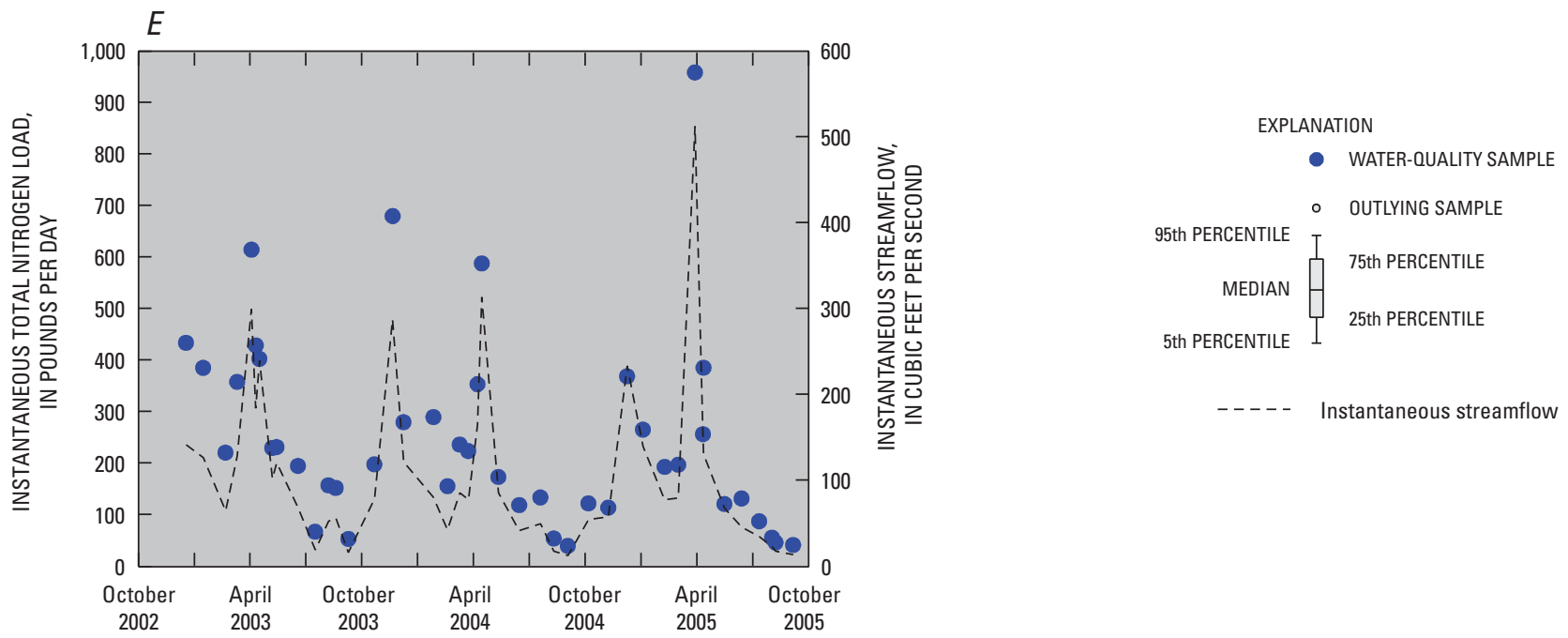

Figure 48. Distribution of $A$, Dissolved nitrite plus nitrate, $B$, Total ammonia plus organic nitrogen, $C$, Total nitrogen, $D$, Total phos-

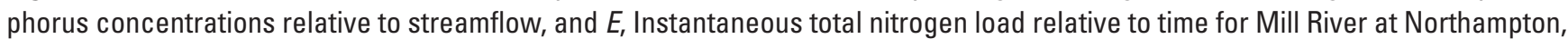
MA, station 01171500. (Refer to table 1 and figure 1 for station location.) 

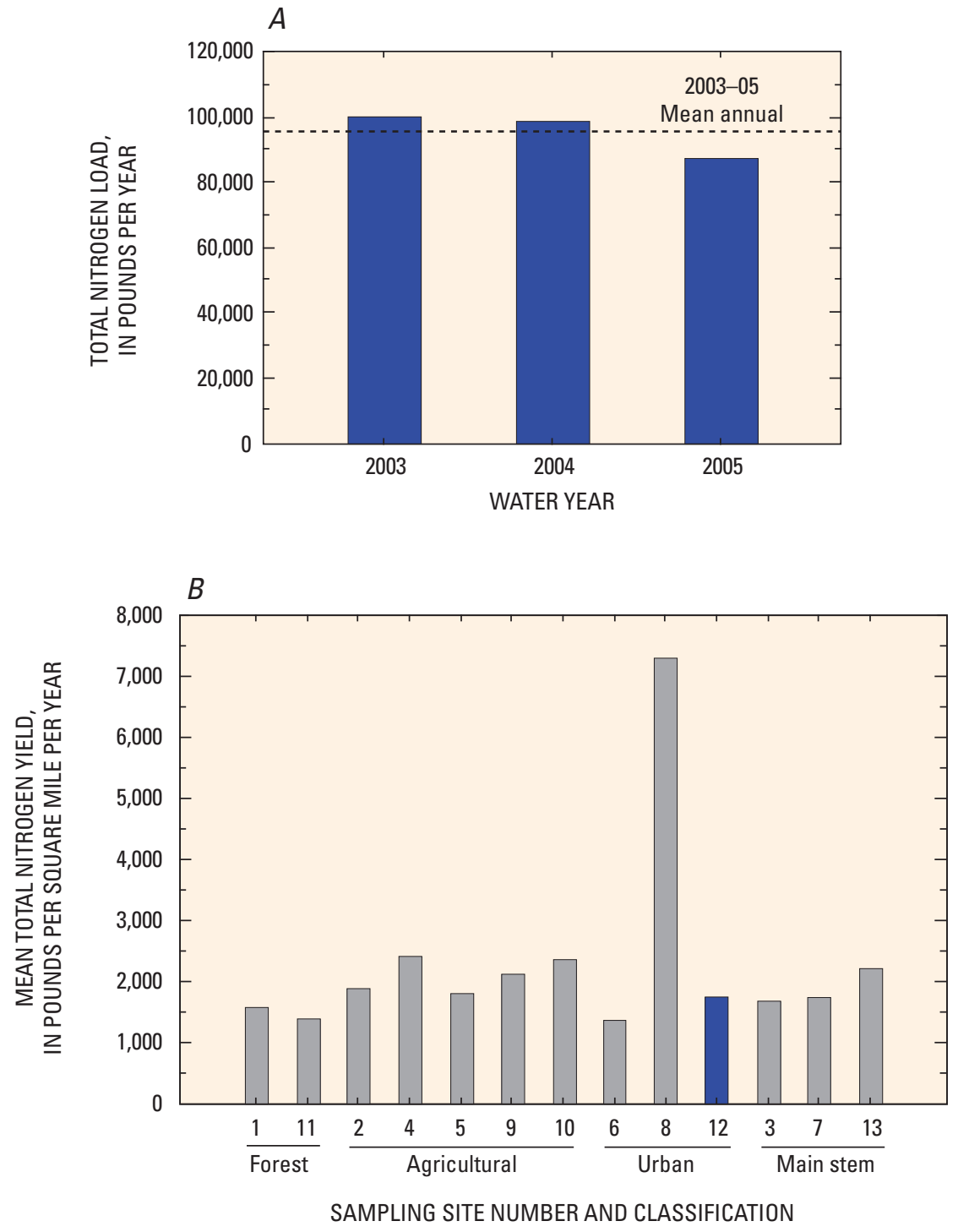

EXPLANATION

Mill River at Northampton, MA

All other river sampling sites

Figure 49. $\quad A$, Total nitrogen load, by year, and $B$, Mean annual total nitrogen yield (2003-05) for Mill River at Northampton, MA, station 01171500 , in relation to all other river sampling sites. (Refer to table 1 and figure 1 for site names and locations.) 


\section{Connecticut River at Thompsonville, CT, Station 01184000}

Connecticut River at Thompsonville, CT, represents a main-stem site in the study area and serves as the outlet site to the upper Connecticut River Basin. The contributing drainage basin upstream from the site encompasses about $9,660 \mathrm{mi}^{2}$ and is about 80 percent forested, 9 percent agriculture, 4 percent urban, and about 6 percent wetlands and barren (fig. 50). Annual streamflow for 1980-2002 averages $12,700,000$ acre-feet, with considerable year-to-year variation (fig. 51A). Annual streamflow for the data-collection period for water years 2003-05 averaged 13,000,000 acre-feet (table 1). Streamflow was less than the long-term mean for the first year and greater than the long-term mean for the second year and about average for the third year of the study (fig. 51A).

Daily mean streamflows and the time distribution of the collection of 41 water-quality samples are shown in figure 51B. The minimum streamflow at which water samples were collected was $4,930 \mathrm{ft}^{3} / \mathrm{s}$, and the maximum streamflow at which samples were collected was $77,200 \mathrm{ft}^{3} / \mathrm{s}$.

The minimum concentration of dissolved oxygen was $6.7 \mathrm{mg} / \mathrm{L}$ and was within the Connecticut water-quality criterion for dissolved oxygen (Connecticut Department of Environmental Protection, 2002). Concentrations of selected water-quality constituents were plotted relative to streamflow (fig. 52). Concentrations of dissolved nitrite plus nitrate ranged from less than 0.126 to $0.632 \mathrm{mg} / \mathrm{L}$ and showed a slight dilution relative to streamflow except at extreme high streamflows (fig. 52A). Total ammonia plus organic nitrogen ranged from 0.22 to $0.46 \mathrm{mg} / \mathrm{L}$ and showed no apparent relation to streamflow (fig. 52B). Concentrations of total nitrogen ranged from 0.44 to $1.0 \mathrm{mg} / \mathrm{L}$ (fig. $52 \mathrm{C}$ ). Concentrations of total phosphorus ranged from 0.021 to $0.122 \mathrm{mg} / \mathrm{L}$ (fig. 52D). The maximum concentration of total phosphorus was observed at the maximum streamflow at which samples were collected. This sample also had the greatest concentration of suspended sediment $(135 \mathrm{mg} / \mathrm{L})$ relative to the other samples. Instantaneous loads of total nitrogen ranged from 14,300 to $288,000 \mathrm{lb} / \mathrm{d}$ (fig. 52E). Ranges of concentrations or values for water-quality constituents not shown in figure 52 are listed below.

\begin{tabular}{|c|c|c|c|c|}
\hline \multirow{2}{*}{$\begin{array}{l}\text { Water-quality } \\
\text { constituent }^{\mathrm{a}}\end{array}$} & \multicolumn{4}{|c|}{$<$, less than; -, not calculated } \\
\hline & $\begin{array}{l}\text { Mini- } \\
\text { mum }\end{array}$ & Mean & Median & $\begin{array}{c}\text { Maxi- } \\
\text { mum }\end{array}$ \\
\hline Specific conductance & 85 & 142 & 141 & 230 \\
\hline $\mathrm{pH}$ & 6.8 & 7.4 & 7.4 & 7.7 \\
\hline Water temperature & .0 & 13.3 & 14.5 & 27 \\
\hline Dissolved oxygen & 6.7 & 10.7 & 10.4 & 14.6 \\
\hline Dissolved nitrite & $<.004$ & - & .007 & .031 \\
\hline Dissolved ammonia & .020 & .057 & .041 & .227 \\
\hline $\begin{array}{l}\text { Dissolved orthophos- } \\
\text { phate (WY 2003-04) }\end{array}$ & $<.01$ & - & $<.01$ & .094 \\
\hline Suspended sediment & 1 & 12 & 3 & 135 \\
\hline
\end{tabular}

The estimated load of total nitrogen varied among years during the study period (appendix A-1; fig. 53A). The mean annual load of total nitrogen was $21,600,000 \mathrm{lb} / \mathrm{yr}$ with a ratio of the standard error of prediction to the mean load of 3.0 percent (table 2, fig. 53A). An estimated 41 percent of the total nitrogen load was transported during the spring (appendix A-2). The mean load estimate at this site represents the cumulative load of total nitrogen leaving the upper Connecticut River Basin. The mean yield of total nitrogen $\left(2,230 \mathrm{lb} / \mathrm{mi}^{2} / \mathrm{yr}\right)$ was greater than the yield at other main-stem sites and at most agricultural and urban sites (fig. 53B). 
Connecticut River at Thompsonville, CT, Station 01184000

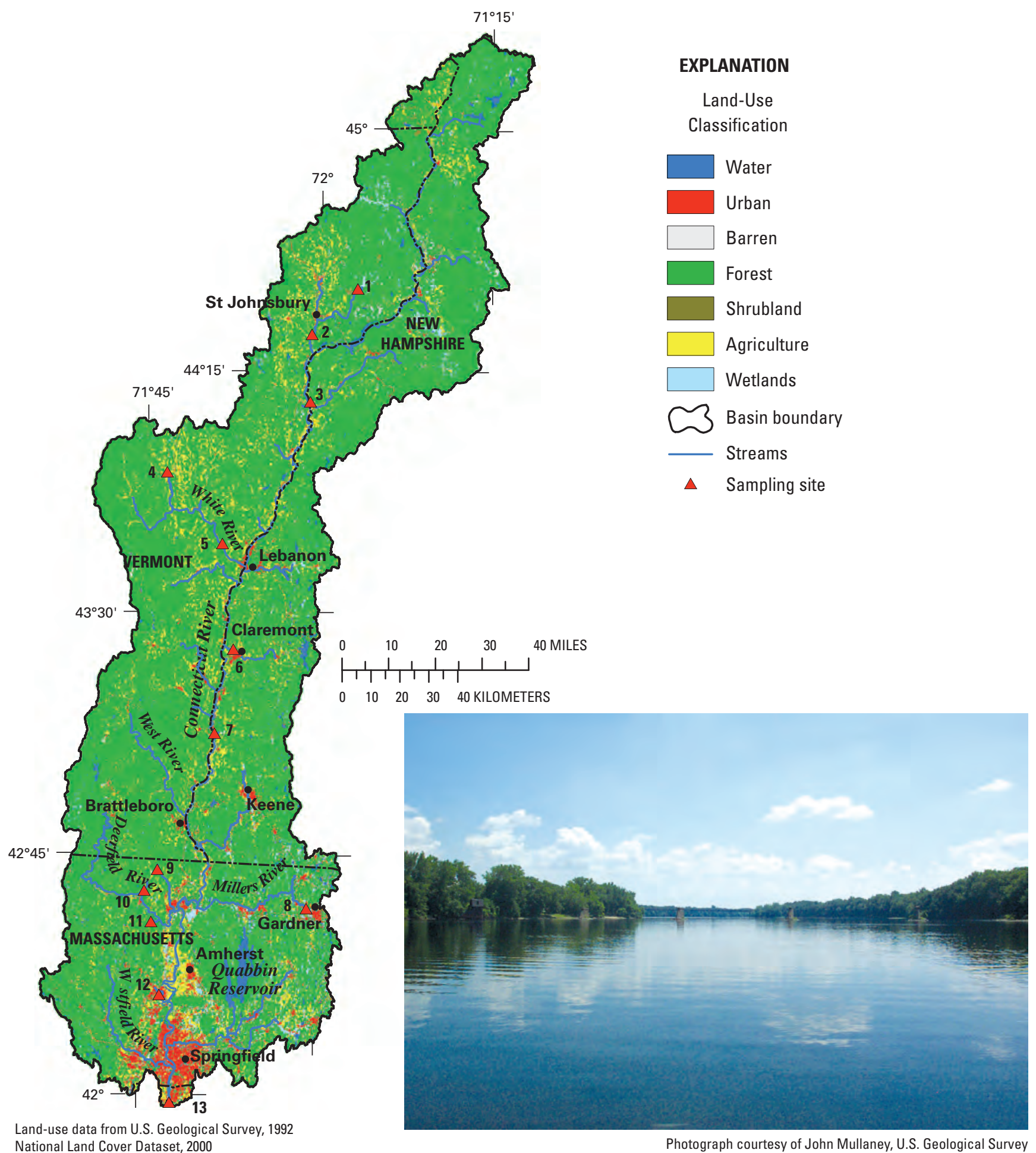

Land-use data from U.S. Geological Survey, 1992 National Land Cover Dataset, 2000

Photograph courtesy of John Mullaney, U.S. Geological Survey

Figure 50. Location, land-use classification, and photograph of sampling site for Connecticut River at Thompsonville, CT, station 01184000. (Refer to table 1 and figure 1 for additional site information.) 

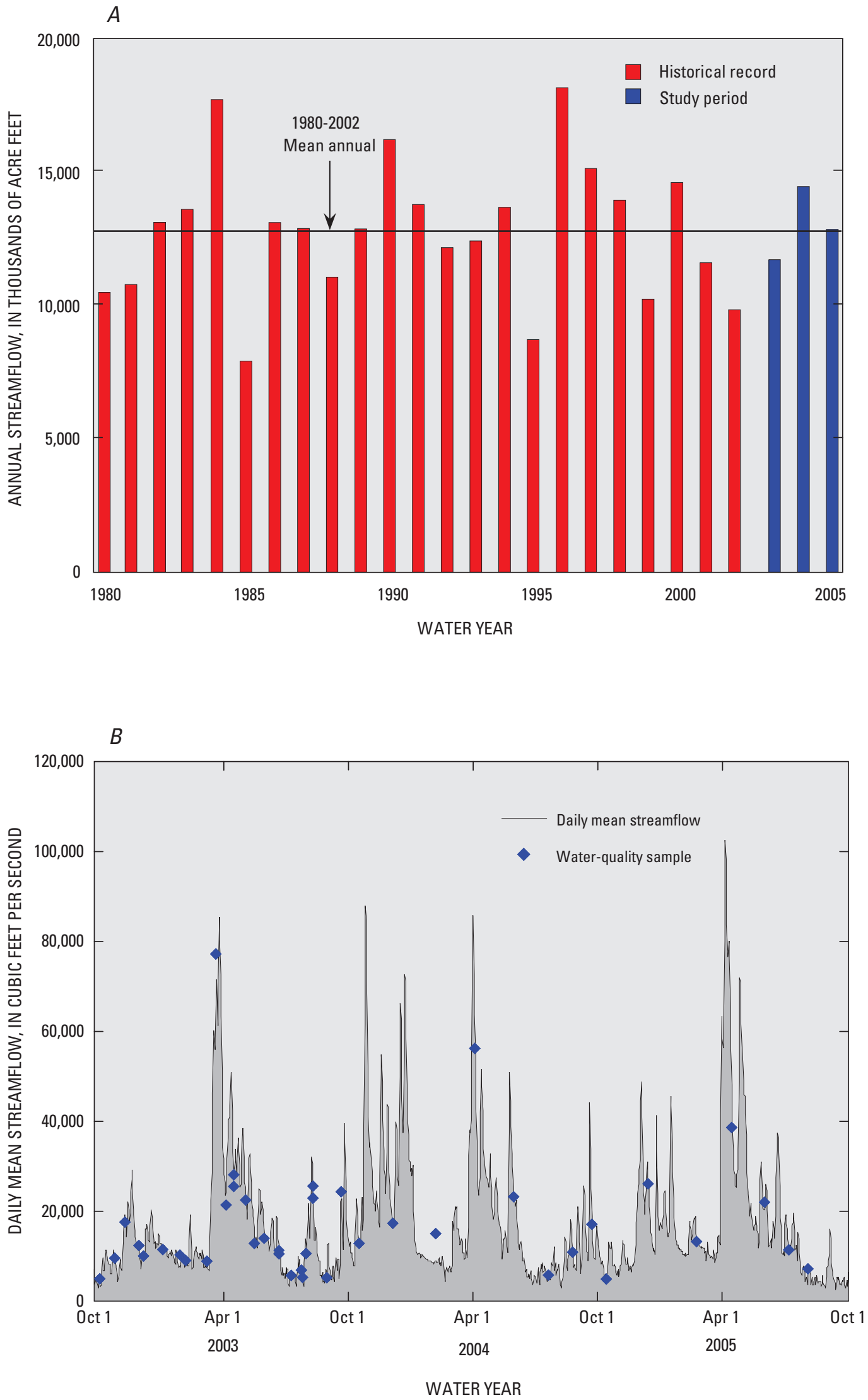

Figure 51. A, Historical and study-period annual streamflow, and $B$, Daily mean streamflow and time distribution of water-quality samples for Connecticut River at Thompsonville, CT, station 01184000. 

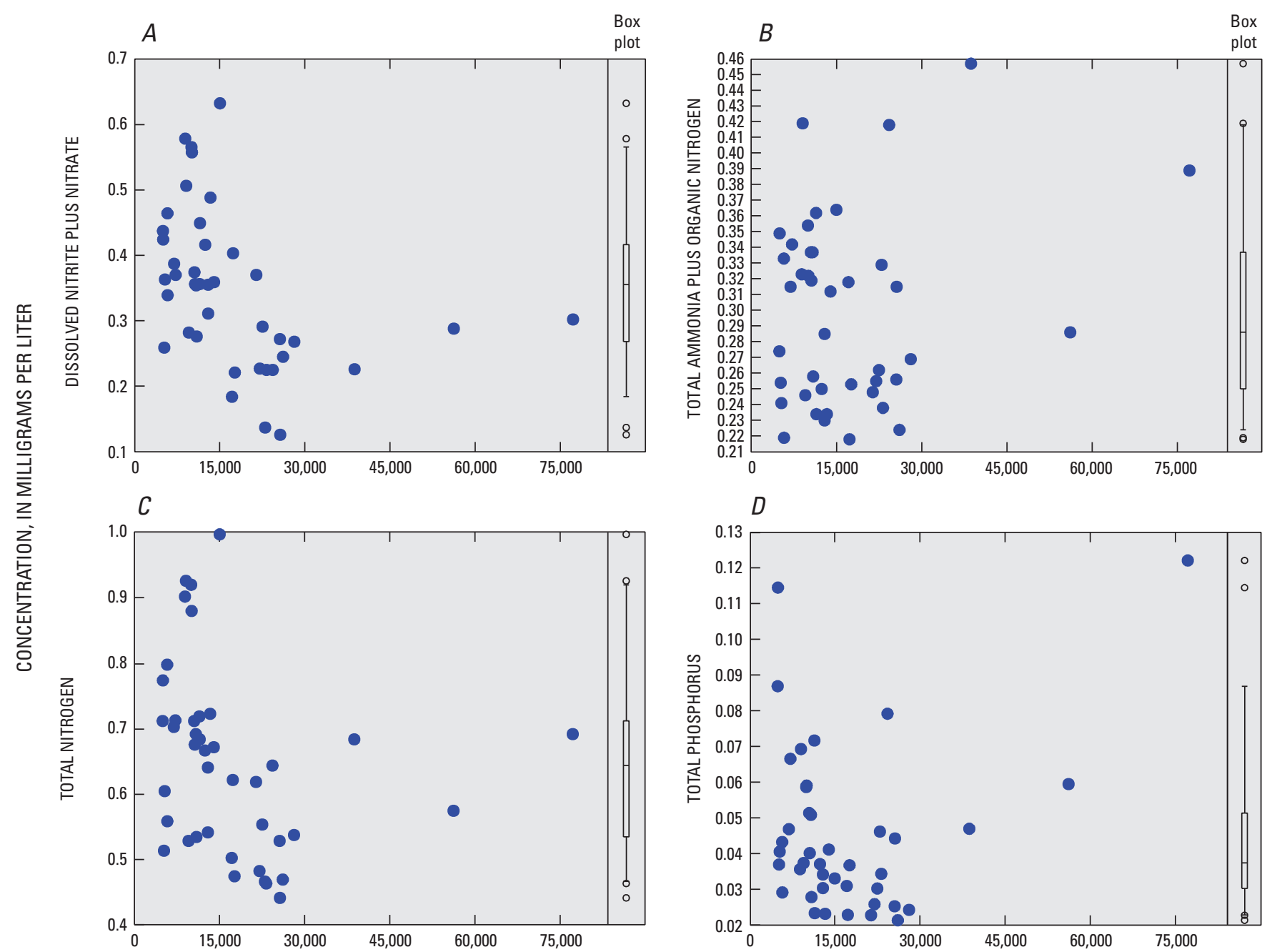

INSTANTANEOUS STREAMFLOW, IN CUBIC FEET PER SECOND
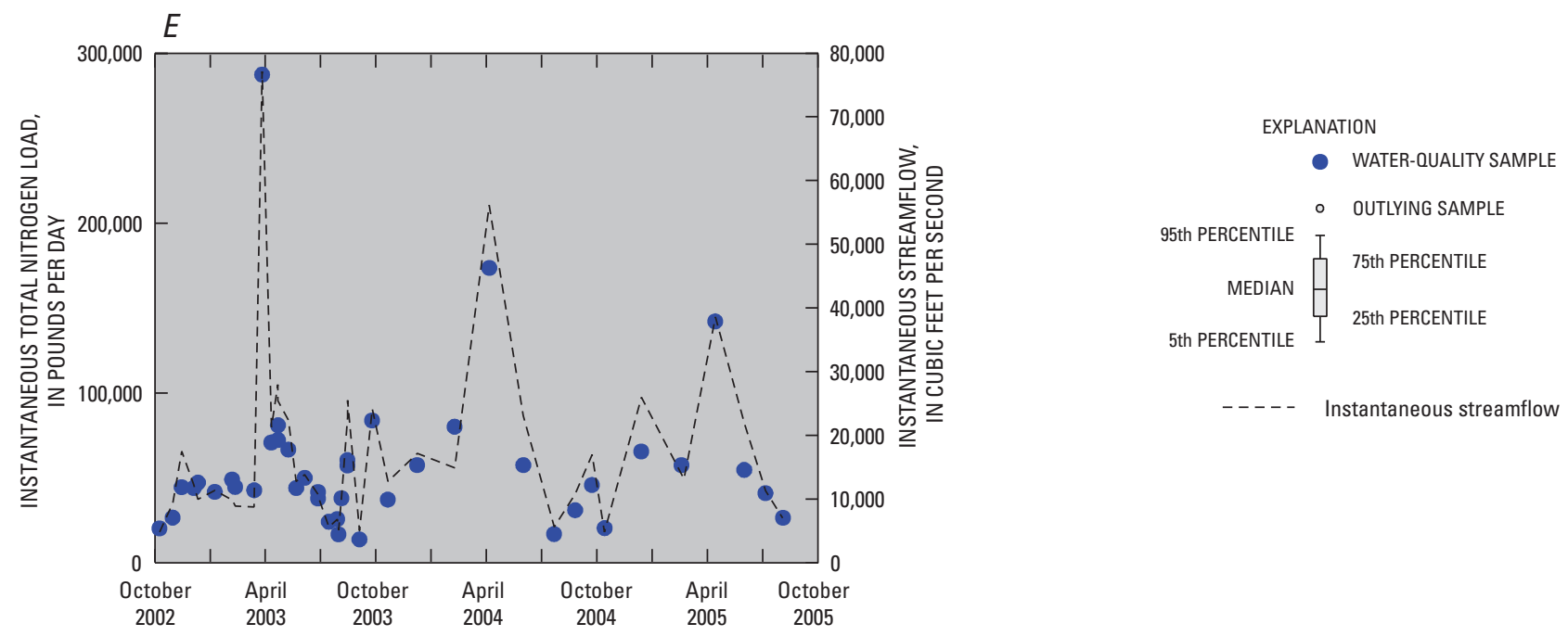

Figure 52. Distribution of $A$, Dissolved nitrite plus nitrate, $B$, Total ammonia plus organic nitrogen, $C$, Total nitrogen, $D$, Total phosphorus concentrations relative to streamflow, and $E$, Instantaneous total nitrogen load relative to time for Connecticut River at Thompsonville, CT, station 01184000. (Refer to table 1 and figure 1 for station location.) 

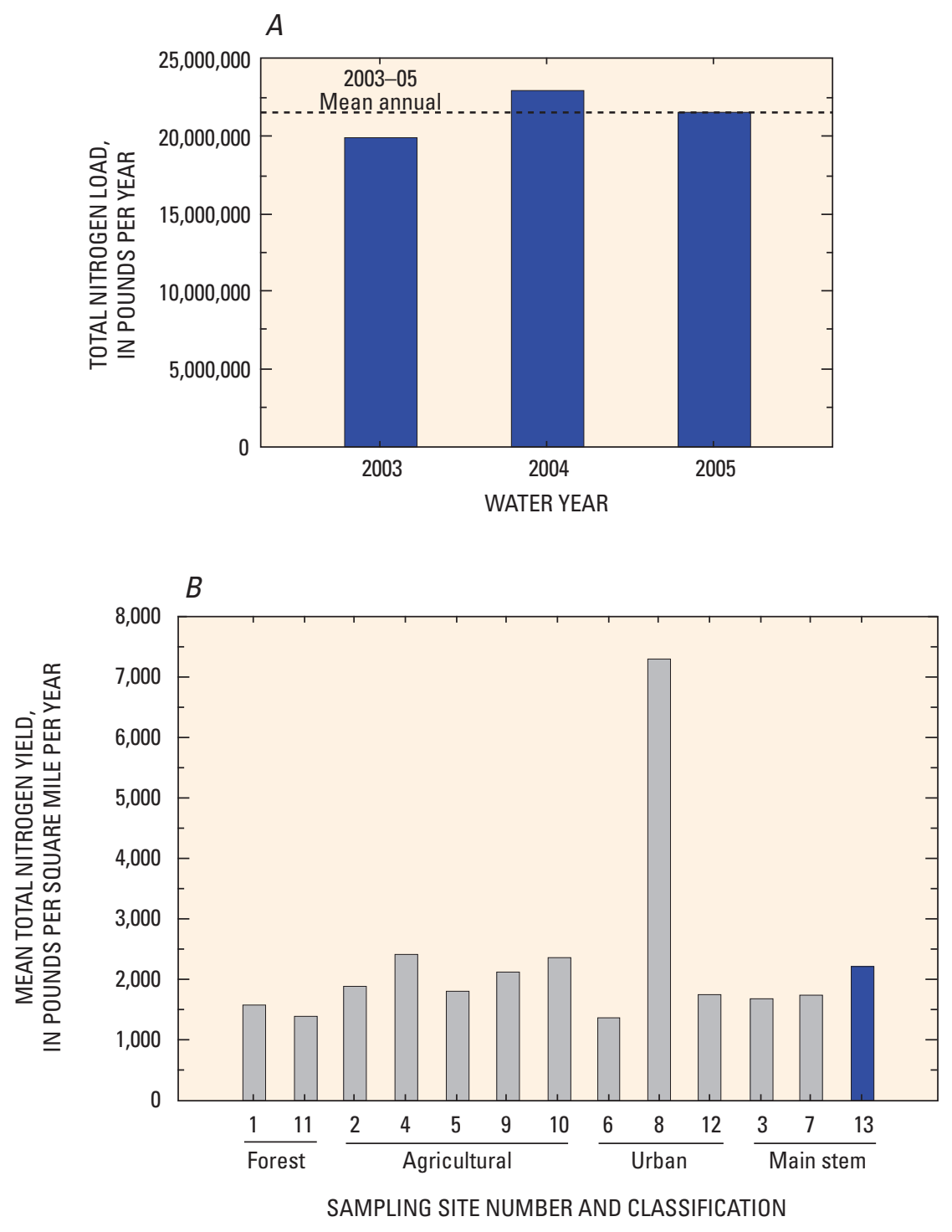

\section{EXPLANATION}

Connecticut River at Thompsonville, CT

All other river sampling sites

Figure 53. $\quad A$, Total nitrogen load, by year, and $B$, Mean annual total nitrogen yield (2003-05) for Connecticut River at Thompsonville, CT, station 01184000, in relation to all other river sampling sites. (Refer to table 1 and figure 1 for site names and locations.) 
Characterization of Total Nitrogen at Wastewater-Treatment Sampling Sites

Data collected for this study were used to characterize the spatial distribution and variability of total nitrogen among 19 wastewater-treatment sampling sites. Sixteen sampling sites were located at municipal wastewater-treatment facilities. Three sampling sites were located at paper mill wastewatertreatment facilities. Summary statistics concentrations and instantaneous loads of total nitrogen are listed in table 3.

Mean concentrations of total nitrogen ranged from 4.4 to $30 \mathrm{mg} / \mathrm{L}$ at wastewater-treatment sampling sites (table 3; fig. 54A). The concentrations of dissolved nitrite plus nitrate and total ammonia plus organic nitrogen, the constituents, which are summed to calculate total nitrogen, varied among wastewater-treatment sampling sites (fig. 54A). Ranges in mean concentrations of total nitrogen at wastewater-treatment sampling sites $(4.4$ to $30 \mathrm{mg} / \mathrm{L})$ were greater than the ranges in mean concentrations of total nitrogen at river sampling sites $(0.19$ to $2.8 \mathrm{mg} / \mathrm{L})$.

Instantaneous mean loads of total nitrogen from municipal wastewater-treatment sampling sites ranged from 36 to $1,780 \mathrm{lb} / \mathrm{d}$ (table 3; fig. 54B). Instantaneous mean loads of total nitrogen at the three paper mill wastewater-treatment sampling sites ranged from 96 to $160 \mathrm{lb} / \mathrm{d}$ (table 3; fig. 54B). Based on the sites and data for this study, the paper mill wastewater-treatment facilities were contributing less total nitrogen load than the municipal wastewater-treatment facilities.

Table 3. Selected characteristics and summary statistics for concentrations of total nitrogen and instantaneous loads of total nitrogen for the wastewater-treatment sampling sites in the upper Connecticut River Basin in New Hampshire, Vermont, and Massachusetts.

[USGS, U.S. Geological Survey; ft 3 s, cubic feet per second; mg/L, milligrams per day; lb/d, pounds per day; Min, minimum; Max, maximum; WWTF, wastewater-treatment facility]

\begin{tabular}{|c|c|c|c|c|c|c|c|c|c|c|}
\hline \multirow{2}{*}{$\begin{array}{l}\text { Site } \\
\text { number } \\
\text { (fig. 1) }\end{array}$} & \multirow{2}{*}{$\begin{array}{c}\text { USGS } \\
\text { station number }\end{array}$} & \multirow[t]{2}{*}{ Station name } & \multirow{2}{*}{$\begin{array}{l}\text { Number } \\
\text { of } \\
\text { samples }\end{array}$} & \multirow{2}{*}{$\begin{array}{c}\text { Mean } \\
\text { instanta- } \\
\text { neous } \\
\text { flow } \\
\left(\mathrm{ft}^{3} / \mathrm{s}\right)\end{array}$} & \multicolumn{3}{|c|}{$\begin{array}{l}\text { Total nitrogen } \\
\text { (mg/L) }\end{array}$} & \multicolumn{3}{|c|}{$\begin{array}{c}\text { Instantaneous total } \\
\text { nitrogen load } \\
(\mathrm{lb} / \mathrm{d})\end{array}$} \\
\hline & & & & & Min & Mean & $\operatorname{Max}$ & Min & Mean & Max \\
\hline $14^{\mathrm{a}}$ & 443558071303001 & Wasau Paper WWTF, NH & 12 & 7.1 & 1.1 & 4.4 & 16 & 44 & 160 & 521 \\
\hline 15 & 442906071354401 & Lancaster WWTF, NH & 10 & 2.1 & 4.7 & 8.8 & 13 & 38 & 106 & 221 \\
\hline 16 & 442436072010001 & St, Johnsbury WWTF, VT & 19 & 2.3 & 4.5 & 12 & 21 & 54 & 146 & 318 \\
\hline 17 & 441827071473701 & Littleton WWTF, NH & 10 & 1.7 & 3.3 & 10 & 18 & 31 & 88 & 131 \\
\hline 18 & 440835072022501 & Woodsville WWTF, NH & 13 & 0.4 & 4.6 & 16 & 59 & 4 & 36 & 119 \\
\hline 19 & 434145072175601 & Hanover WWTF, NH & 17 & 3.1 & 19 & 30 & 38 & 201 & 498 & 697 \\
\hline 20 & 433844072185501 & $\begin{array}{l}\text { Hartford/White River } \\
\text { Junction WWTF, VT }\end{array}$ & 10 & 1.7 & 23 & 30 & 35 & 130 & 267 & 376 \\
\hline 21 & 433813072192001 & Lebanon WWTF, NH & 17 & 3.4 & 12 & 19 & 29 & 194 & 346 & 658 \\
\hline 22 & 432359072234001 & Claremont WWTF, NH & 14 & 2.5 & 4.1 & 14 & 22 & 55 & 185 & 330 \\
\hline 23 & 431648072280801 & Springfield WWTF, VT & 14 & 2.1 & 8.4 & 12 & 21 & 57 & 145 & 293 \\
\hline 24 & 430745072263701 & Bellows Falls WWTF, VT & 10 & 1.4 & 12 & 21 & 32 & 73 & 147 & 262 \\
\hline $25^{\mathrm{a}}$ & 425322072323701 & $\begin{array}{l}\text { Fibermark Products } \\
\text { WWTF, VT }\end{array}$ & 10 & 2.5 & 2.3 & 7.3 & 11 & 31 & 96 & 150 \\
\hline 26 & 425029072325901 & Brattleboro WWTF, VT & 12 & 3.2 & 13 & 20 & 35 & 200 & 330 & 636 \\
\hline $27^{\mathrm{a}}$ & 423542072031001 & Seaman Paper WWTF, MA & 11 & 1.4 & 3.3 & 14 & 50 & 21 & 97 & 262 \\
\hline 28 & 423413072011201 & Gardner WWTF, MA & 10 & 6.2 & 9.5 & 22 & 28 & 478 & 702 & 914 \\
\hline 29 & 421132072365001 & Holyoke WWTF, MA & 11 & 12.8 & 1.9 & 5.6 & 12 & 150 & 339 & 621 \\
\hline 30 & 420908072373301 & Chicopee WWTF, MA & 15 & 17.3 & 13 & 18 & 24 & 1,080 & 1,640 & 5,330 \\
\hline 31 & 420702072435601 & Westfield WWTF, MA & 11 & 6.4 & 13 & 19 & 26 & 500 & 654 & 822 \\
\hline 32 & 420508072351401 & Springfield WWTF, MA & 14 & 66.5 & 3.2 & 5.0 & 6.3 & 1,290 & 1,780 & 2,150 \\
\hline
\end{tabular}

${ }^{a}$ Paper mill. 


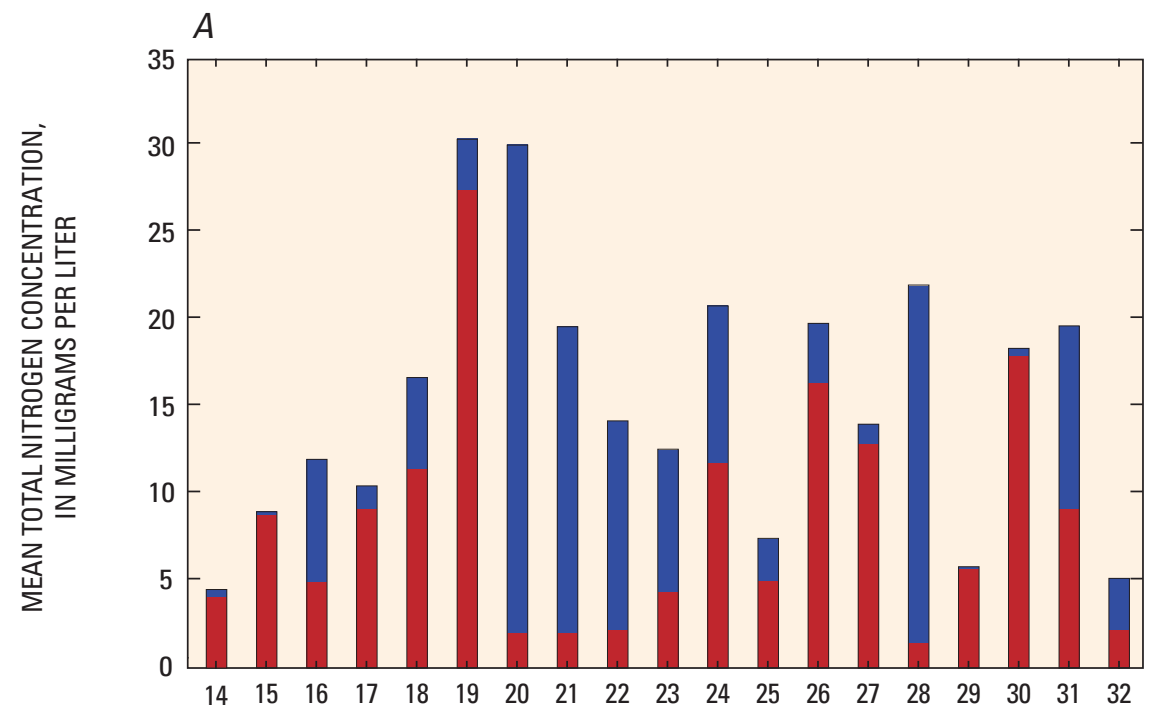

\section{EXPLANATION}

Dissolved nitrite plus nitrate

Total ammonia plus organic nitrogen

\section{EXPLANATION}

Municipal wastewatertreatment facility

Paper mill wastewater-

treatment facility

Figure 54. $A$, Mean total nitrogen concentration, and $B$, Instantaneous mean total nitrogen load for wastewatertreatment sampling sites in the upper Connecticut River Basin in New Hampshire, Vermont, and Massachusetts. (Refer to table 1 and figure 1 for site names and locations.) 


\section{Comparison of Total Nitrogen Concentrations and Yields Among Site Types}

The sampling sites were grouped to compare concentrations and yields of total nitrogen among site types. The five site types were forested, agricultural, urban, main stem, and wastewater treatment. Forest was the predominant land use at all sites in the basin. Sites that were selected to represent agricultural and urban land use in this study generally had agriculture and urban land use as the second predominant land use in the basin.

The median concentration of total nitrogen was $0.24 \mathrm{mg} / \mathrm{L}$ at forested sites, $0.48 \mathrm{mg} / \mathrm{L}$ at agricultural sites, $0.54 \mathrm{mg} / \mathrm{L}$ at urban sites, $0.48 \mathrm{mg} / \mathrm{L}$ at main-stem sites, and $14 \mathrm{mg} / \mathrm{L}$ at wastewater-treatment sites (fig. 55). Comparison of concentrations of total nitrogen among the site types indicated significant differences. Concentrations of total nitrogen at forested sites were significantly less than at all other site types $(\mathrm{p}<0.05)$. Concentrations of total nitrogen at agricultural, urban, and main-stem sites were not significantly different among each other ( $p>0.05)$, but were significantly greater $(\mathrm{p}<0.05)$ than at forested sites and significantly less than concentrations at wastewater-treatment sites $(\mathrm{p}<0.05)$. Concentrations of total nitrogen at wastewater-treatment sites were significantly different from those at all other site types $(\mathrm{p}<0.05)$.

Nitrogen yields at forested sites generally were less than yields at agricultural and urban sites; however, nitrogen yields at agricultural sites generally were greater than yields at urban sites. Annual yields of total nitrogen ranged from 732 to $1,920\left(\mathrm{lb} / \mathrm{mi}^{2}\right) / \mathrm{yr}$ at forested sites; 1,550 to $2,980\left(\mathrm{lb} / \mathrm{mi}^{2}\right) / \mathrm{yr}$ at agricultural sites; 1,280 to $1,860\left(\mathrm{lb} / \mathrm{mi}^{2}\right) / \mathrm{yr}$ at urban sites that were not directly affected by wastewater effluent; 7,090 to $7,700\left(\mathrm{lb} / \mathrm{mi}^{2}\right) / \mathrm{yr}$ at a urban site directly affected by wastewater effluent; and 1,300 to 2,390 $\left(\mathrm{lb} / \mathrm{mi}^{2}\right) / \mathrm{yr}$ at main-stem sites (appendix A-1).

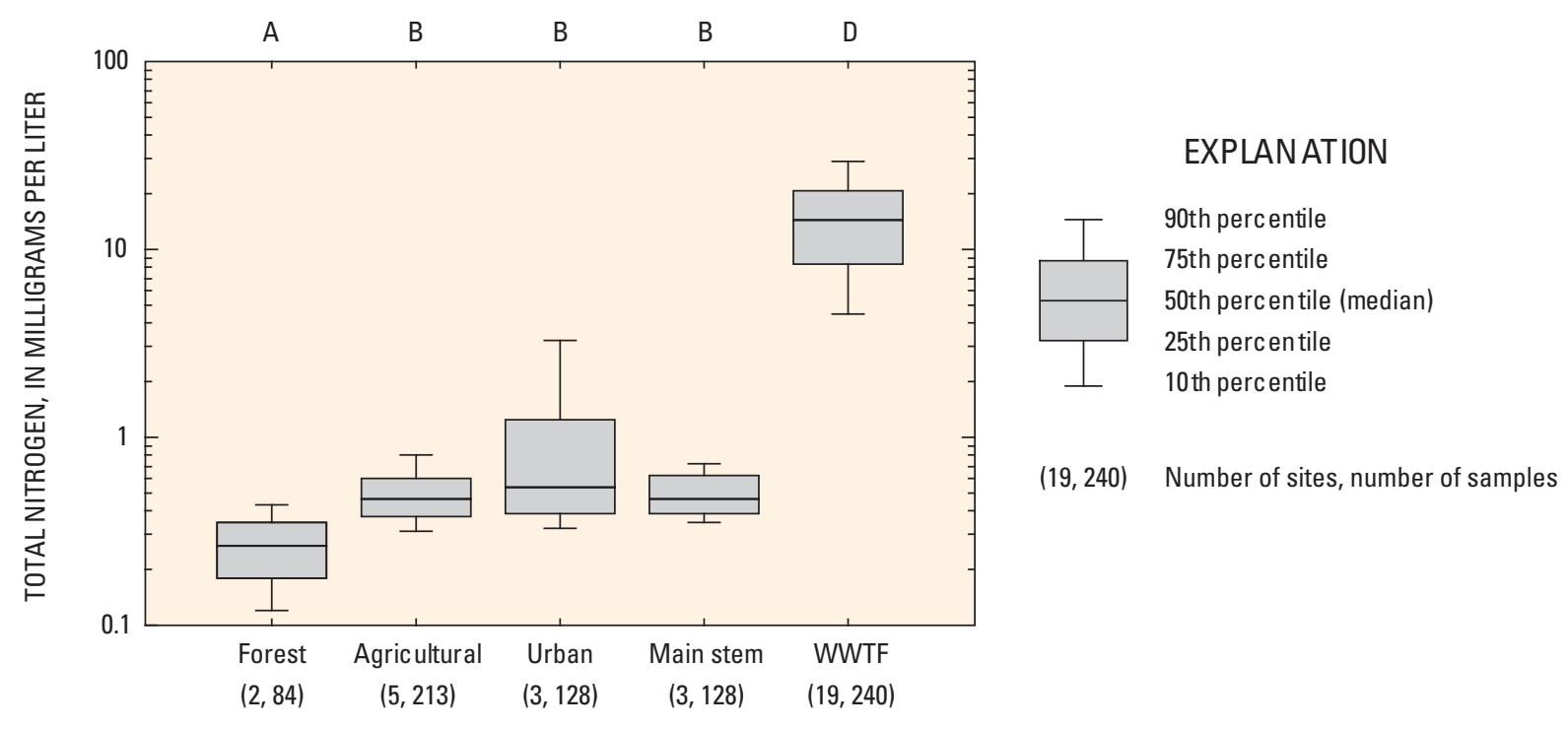

Figure 55. Total nitrogen concentrations among site types in the upper Connecticut River Basin in New Hampshire, Vermont, and Massachusetts. (WWTF, wastewater-treatment facility; results of Tukey's multiple comparison test [Helsel and Hirsch, 1992] among sites are presented as letters, and concentrations with at least one letter in common do not differ significantly.) 


\section{Summary and Conclusions}

Low concentrations (less than 3.5 milligrams per liter $(\mathrm{mg} / \mathrm{L})$ ) of dissolved oxygen (hypoxia) caused by nitrogen enrichment often occur during the summer in the western part of Long Island Sound (LIS). Excess nitrogen levels lead to the enhanced growth of algae, which eventually die and decay, consuming oxygen in the process. The ensuing hypoxic conditions have resulted in the exceedance of dissolved-oxygen water-quality standards in Long Island Sound (LIS) during the summer. As a result, Connecticut and New York developed a Total Maximum Daily Load (TMDL) for dissolved oxygen that specifies the maximum amount of nitrogen that can be discharged to LIS without exceeding water-quality standards for dissolved oxygen. According to the TMDL analysis, an annual baseline load of about 53,300 tons of nitrogen is delivered to LIS from all sources in Connecticut and New York combined. An additional estimated 13,600 tons of nitrogen reach LIS annually from the portion of the watershed originating north of Connecticut. Of this total load, an estimated 12,500 tons of nitrogen are delivered to LIS by way of the Connecticut River.

To better define loads in the upper Connecticut River Basin, the U.S. Geological Survey (USGS), in cooperation with the New England Interstate Water Pollution Control Commission, designed and operated a surface-water quality monitoring network from December 2002 to September 2005 to collect water-quality and streamflow data and to use these data to determine the current concentrations, loads, and yields of nitrogen from selected sites in the upper Connecticut River Basin.

A study was conducted at 13 river sites in the upper Connecticut River Basin. Ten sites were selected to represent contributions of nitrogen from forested, agricultural, and urban land. Forest was the predominant land use at all sites in the basin. Sites that were selected to represent agricultural and urban land use in this study generally had agriculture and urban land use as the second predominant land use in the basin. Three sites were distributed spatially on the main stem of Connecticut River to assess the cumulative loads of total nitrogen. To further improve the understanding the sources and concentrations and loads of total nitrogen in the upper Connecticut River Basin, ambient water-quality sampling at river sites was supplemented with sampling and analysis of effluent from wastewater treatment at 19 municipal and paper mill wastewater-treatment facilities.

Mean concentrations of total nitrogen ranged from 0.19 to 2.8 milligrams per liter $(\mathrm{mg} / \mathrm{L})$ at river sampling sites.
Instantaneous mean loads of total nitrogen ranged from 162 to 58,300 pounds per day $(\mathrm{lb} / \mathrm{d})$. Estimated mean annual loads of total nitrogen at river sampling sites ranged from 49,100 to 21.6 million pounds per year (lb/yr) with about 30 to 55 percent being transported during the spring. The estimated mean annual yields of total nitrogen ranged from 1,190 to 7,300 pounds per square mile per year $\left(\mathrm{lb} / \mathrm{mi}^{2}\right) / \mathrm{yr}$.

Mean concentrations of total nitrogen ranged from 4.4 to $30 \mathrm{mg} / \mathrm{L}$ at wastewater-treatment sampling sites. Instantaneous mean loads of total nitrogen from municipal wastewater-treatment facilities ranged from 36 to $1,780 \mathrm{lb} / \mathrm{d}$. Instantaneous mean loads of total nitrogen from three paper mill wastewatertreatment facilities ranged from 96 to $160 \mathrm{lb} / \mathrm{d}$.

Sampling sites were grouped to compare concentrations and yields of total nitrogen among forested, agricultural, urban, main stem, and wastewater-treatment site types. The median concentration of total nitrogen was $0.24 \mathrm{mg} / \mathrm{L}$ at forested sites, $0.48 \mathrm{mg} / \mathrm{L}$ at agricultural sites, $0.54 \mathrm{mg} / \mathrm{L}$ at urban sites, $0.48 \mathrm{mg} / \mathrm{L}$ at main-stem sites, and $14 \mathrm{mg} / \mathrm{L}$ at wastewater-treatment sites. Concentrations of total nitrogen at forested sites were significantly less than at all other site types $(\mathrm{p}<0.05)$. Concentrations of total nitrogen at agricultural, urban, and main-stem sites were not significantly different among each other ( $p>0.05)$ but were significantly greater $(\mathrm{p}<0.05)$ than at forested sites and significantly less than concentrations at wastewater-treatment sites $(\mathrm{p}<0.05)$. Concentrations of total nitrogen at wastewater-treatment sites were significantly different from all other site types $(\mathrm{p}<0.05)$.

Nitrogen yields at forested sites generally were less than yields at agricultural and urban sites; however, nitrogen yields at agricultural sites generally were greater than yields at urban sites. Annual yields of total nitrogen ranged from 732 to $1,920\left(\mathrm{lb} / \mathrm{mi}^{2}\right) / \mathrm{yr}$ at forested sites; 1,550 to $2,980\left(\mathrm{lb} / \mathrm{mi}^{2}\right) / \mathrm{yr}$ at agricultural sites; 1,280 to $1,860\left(\mathrm{lb} / \mathrm{mi}^{2}\right) / \mathrm{yr}$ at urban sites that were not directly affected by wastewater effluent; 7,090 to $7,700\left(\mathrm{lb} / \mathrm{mi}^{2}\right) / \mathrm{yr}$ at a urban site directly affected by wastewater effluent; and 1,300 to $2,390\left(\mathrm{lb} / \mathrm{mi}^{2}\right) / \mathrm{yr}$ at main-stem sites.

In this study, the mean annual load and yield of total nitrogen at the Connecticut River at Wells River, VT, was estimated at $4.47 \mathrm{million} \mathrm{lb} / \mathrm{yr}$ and 1,690 $\left(\mathrm{lb} / \mathrm{mi}^{2}\right) / \mathrm{yr}$, respectively. The mean annual load and yield of total nitrogen at the Connecticut River at North Walpole, $\mathrm{NH}$, was estimated at 9.60 million $\mathrm{lb} / \mathrm{yr}$ and $1,750\left(\mathrm{lb} / \mathrm{mi}^{2}\right) / \mathrm{yr}$, respectively. The mean annual load and yield of total nitrogen leaving the upper Connecticut River Basin, as estimated at the Connecticut River at Thompsonville, CT, was 21.6 million lb/yr and $2,230\left(\mathrm{lb} / \mathrm{mi}^{2}\right) / \mathrm{yr}$, respectively. 


\section{References Cited}

Akaike, H., 1981, Likelihood of a model and information criterion: Journal of Econometrics, v. 16, p. 13-14.

Connecticut Department of Environmental Protection, 2002, Water-quality standards: Hartford, CT, Connecticut Department of Environmental Protection, variously paged.

Childress, C.J.O., Foreman, W.T., Connor, B.F., and Maloney, T.J., 1999, New reporting procedures based on longterm method detection levels and some considerations for interpretations of water-quality data provided by the U.S. Geological Survey National Water Quality Laboratory: U.S. Geological Survey Open-File Report 99-193, 19 p.

Garabedian, S.P., Coles, J.F., Grady, S.J., Trench, E.C.T., and Zimmerman, M.J., 1998, Water quality in the Connecticut, Housatonic, and Thames River Basins, Connecticut, Massachusetts, New Hampshire, and Vermont, 1992-95: U.S. Geological Survey Circular 1155, 32 p.

Grady, S.J., and Garabedian, S.P., 1991, National Water-Quality Assessment Program-The Connecticut River and Long Island Sound Coastal Rivers: U.S. Geological Survey Open-File Report 91-159, 2 p.

Helsel, D.R., 2005, Insider censoring: Distortion of data with nondetects: Human and Ecological Risk Assessment, v. 11, p. 1127-1137.

Helsel, D.R., and Hirsch, R.M., 1992, Statistical methods in water resources: New York, Elsevier Science Publishers, $522 \mathrm{p}$.

Keirstead, Chandlee, Kiah, R.G., Brown, R.O., and Ward, S.L., 2003, Water resources data, New Hampshire and Vermont, water year 2003: U.S. Geological Survey Water-Data Report NH-VT-03-1, 323 p.

Keirstead, Chandlee, Kiah, R.G., Ward, S.L., and Hilgendorf, G.S., 2004, Water resources data, New Hampshire and Vermont, water year 2004: U.S. Geological Survey Water-Data Report NH-VT-04-1, 335 p.

Kiah, R.G., Keirstead, Chandlee, Brown, R.O., and Hilgendorf, G.S., 2005, Water resources data, New Hampshire and Vermont, water year 2005: U.S. Geological Survey WaterData Report NH-VT-05-1, 309 p.

Massachusetts Department of Environmental Protection, 2005, Massachusetts surface water quality standards, Division of Water Pollution Control, accessed December 2005, at http://www.mass.gov/dep/water/laws/regulati.htm\#wqual.
Moore, R.B., Johnston, C.M., Robinson, K.W., and Deacon, J.R., 2004, Estimation of total nitrogen and total phosphorus in New England streams using spatially referenced regression models: U.S. Geological Survey Scientific Investigations Report 2004-5012, 42 p.

Mueller, D.K., Hamilton, P.A., Helsel, D.R., Hitt, K.J., and Ruddy, B.C., 1995, Nutrients in ground water and surface water of the United States-An analysis of data through 1992: U.S. Geological Survey Water Resources Investigations Report 95-4031, 74 p.

Mullaney, J.R., 2004, Summary of water quality trends in the Connecticut River, 1968-1998: American Fisheries Society Monograph, v. 9, p. 273-286.

Mullaney, J.R., Schwarz, G.E., and Trench, E.C.T., 2002, Estimation of nitrogen yields and loads from basins draining to Long Island Sound, 1998-98: U.S. Geological Survey Water-Resources Investigations Report 02-4044, 84 p.

New Hampshire Department of Environmental Services, 2004, Surface water-quality assessments, sections 305(b) and 303(d), Consolidated assessment and listing methodology: Concord, NH, Watershed Management Bureau, variously paged.

New York State Department of Environmental Conservation/ Connecticut Department of Environmental Protection, 2000, A total maximum daily load analysis to achieve water-quality standards for dissolved oxygen in Long Island Sound: Albany, NY, and Hartford, CT, New York State Department of Environmental Conservation/Connecticut Department of Environmental Protection, 73 p.

Runkel, R.L., Crawford, C.G., and Cohn, T.A., 2004, Load estimator (LOADEST) —A FORTRAN program for estimating constituent loads in streams and rivers: U.S. Geological Survey Techniques and Methods, book 4, chap. A5, 69 p., available online at http://pubs.water.usgs.gov/tm4A5.

SAS Institute, Inc., 1998, Statview user's guide, version 5: Cary, NC, SAS Institute, Inc.

SAS Institute, Inc., 2000, SAS/STAT user's guide, version 8: Cary, NC, SAS Institute, Inc.

Seitzinger, S.P., Styles, R.V., Boyer, E.W., Alexander, R.B., Billen, Gilles, Howarth, R.W., Mayer, Bernhard, and Breemen, N.V., 2002, Nitrogen retention in rivers-Model development and application to watersheds in the northeastern U.S.A.: Biogeochemistry, v. 57/58, p. 199-237. 
Socolow, R.S., Zanca, J.L., Driskell, T.R., and Ramsbey, L.R., 2003, Water resources data, Massachusetts and Rhode Island, water year 2003: U.S. Geological Survey WaterData Report MA-RI-03-1, 368 p.

Socolow, R.S., Comeau, L.Y., Murino, Domenic, Jr., 2004, Water resources data, Massachusetts and Rhode Island, water year 2004: U.S. Geological Survey Water-Data Report MA-RI-04-1, 310 p.

Socolow, R.S., Leighton, C.R., Whitley, J.F., and Ramsbey, L.R., 2005, Water resources data, Massachusetts and Rhode Island, water year 2005: U.S. Geological Survey WaterData Report MA-RI-05-1, 348 p.

Spahr, N.E., and Boulger, R.W., 1997, Interim results of quality-control sampling of surface-water for the Upper Colorado River National Water-Quality Assessment Study Unit, water years 1995-96: U.S. Geological Survey WaterResources Investigations Report 97-4227, 34 p.

Trench, E.C.T., 1999, Nutrient sources and loads in the Connecticut, Housatonic, and Thames River Basins: U.S. Geological Survey Water-Resources Investigations Report 99-4236, 66 p.
U.S. Environmental Protection Agency, State of Connecticut, State of New York, Interstate Sanitation Commission, National Oceanic and Atmospheric Administration, 1985, Long Island Sound estuarine study, water quality management strategy: $10 \mathrm{p}$.

U.S. Geological Survey, 2000, National land cover data (NLCD) circa 1992, completed nationwide September 2000, accessed November 2004, at http://seamless.usgs.gov/.

Vermont Water Resources Board, 2000, Vermont Water Quality Standards: Montpelier, VT, 61 p.

Wilde, F.D., and Radtke, D.B., 1998a, Collection of water samples: U.S. Geological Survey Techniques of WaterResources Investigations, Handbooks for Water-Resources Investigations, National field manual for the collection of water-quality data, book 9, chap. A4, variously paged.

Wilde, F.D., and Radtke, D.B., 1998b, Field measurements: U.S. Geological Survey Techniques of Water-Resources Investigations, Handbooks for Water-Resources Investigations, National field manual for the collection of waterquality data, book 9, chap. A6, variously paged. 

Appendix A: Supplemental Data 


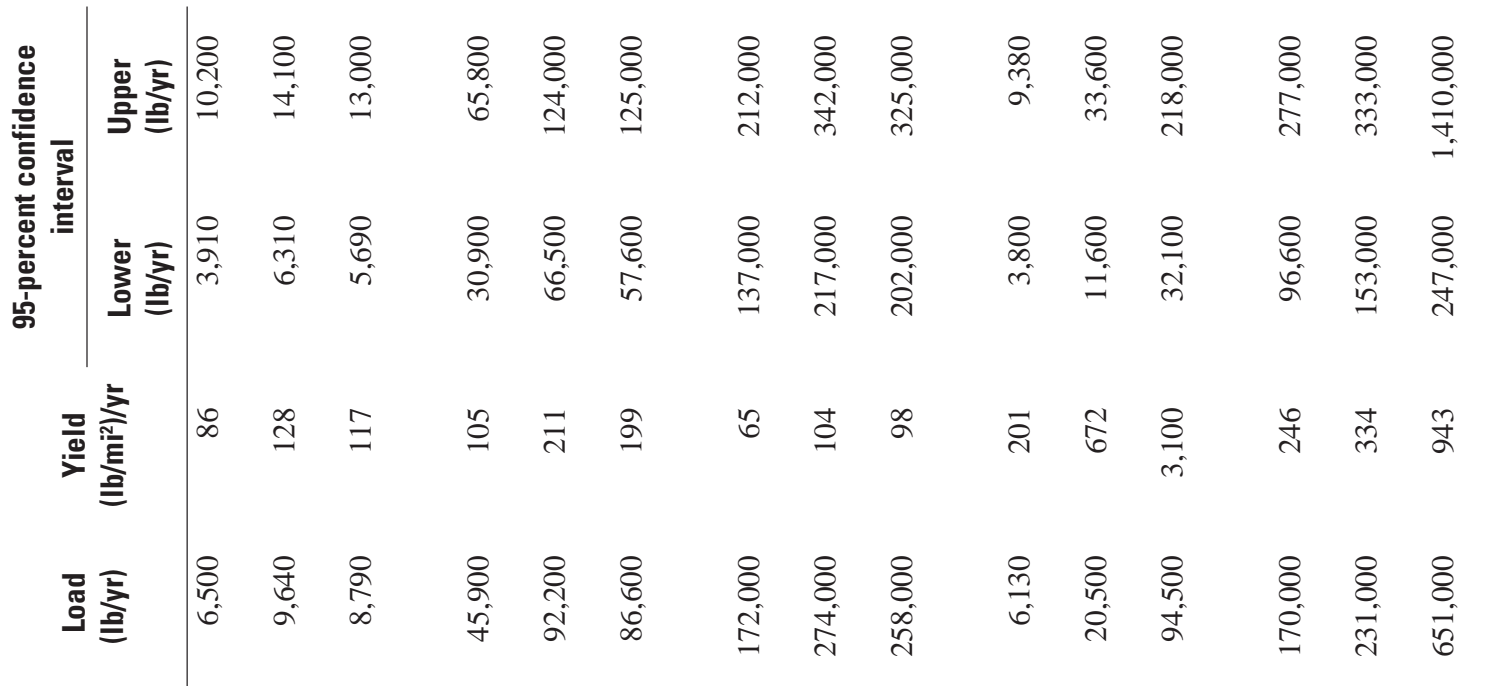

\begin{tabular}{|c|c|c|c|c|c|c|c|c|c|c|c|c|c|c|c|}
\hline 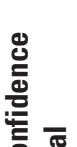 & 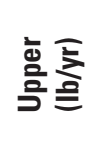 & 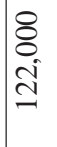 & $\begin{array}{l}\delta \\
\delta \\
i \\
\text { d }\end{array}$ & $\begin{array}{l}8 \\
8 \\
\text { - } \\
-\end{array}$ & $\begin{array}{l}8 \\
\text { ळi } \\
\stackrel{n}{2}\end{array}$ & $\begin{array}{l}8 \\
8 \\
8 \\
8 \\
-\end{array}$ & $\begin{array}{l}8 \\
8 \\
0 \\
\infty \\
\infty\end{array}$ & $\begin{array}{l}8 \\
0 \\
0 \\
0 \\
0 \\
\text { m. }\end{array}$ & $\begin{array}{l}8 \\
8 \\
8 \\
8 \\
0 \\
\text { in }\end{array}$ & 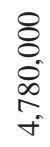 & $\frac{8}{8}$ & $\begin{array}{l}8 \\
\stackrel{0}{2}\end{array}$ & $\begin{array}{l}8 \\
\varnothing \\
\infty \\
\infty\end{array}$ & $\begin{array}{l}8 \\
8 \\
\therefore \\
\\
-1\end{array}$ & $\begin{array}{l}8 \\
8 \\
8 \\
\stackrel{\infty}{\infty} \\
\stackrel{\infty}{-1}\end{array}$ \\
\hline 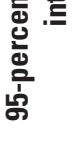 & 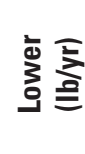 & $\begin{array}{l}8 \\
\stackrel{\infty}{-} \\
\bar{\sigma}\end{array}$ & $\begin{array}{l}8 \\
\vdots \\
\grave{1}\end{array}$ & $\begin{array}{l}8 \\
\infty \\
\infty \\
0 \\
0\end{array}$ & $\begin{array}{l}8 \\
\text { ปิ } \\
\text { กิ }\end{array}$ & $\begin{array}{l}8 \\
\substack{\infty \\
\infty}\end{array}$ & $\begin{array}{l}8 \\
8 \\
8 \\
0 \\
0\end{array}$ & $\begin{array}{l}8 \\
8 \\
\stackrel{i}{1} \\
\text { ஸे }\end{array}$ & $\begin{array}{l}8 \\
8 \\
8 \\
8 \\
\text { n }\end{array}$ & $\begin{array}{l}8 \\
8 \\
0 \\
+ \\
+ \\
+ \\
+\end{array}$ & $\frac{8}{8}$ & $\underset{\infty}{\stackrel{8}{\infty}}$ & $\frac{8}{80}$ & $\begin{array}{l}8 \\
8 \\
0 \\
\& \\
0\end{array}$ & $\begin{array}{l}8 \\
8 \\
0 \\
0 \\
0 \\
-\end{array}$ \\
\hline & $\frac{2}{2}$ & $\stackrel{\circ}{\underset{f}{\sim}}$ & న్ & $\begin{array}{l}8 \\
\\
-1\end{array}$ & $\begin{array}{l}\text { n } \\
n \\
-1\end{array}$ & $\begin{array}{l}\text { ڤ్ } \\
\text { in }\end{array}$ & $\begin{array}{l}\mathscr{R} \\
\infty \\
-\infty\end{array}$ & 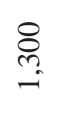 & $\begin{array}{l}\text { qu } \\
\text { i }\end{array}$ & 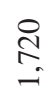 & 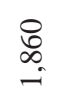 & 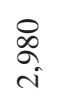 & $\begin{array}{l}8 \\
\text { ñ } \\
i n\end{array}$ & $\underset{:}{\stackrel{\infty}{0}}$ & $\begin{array}{l}\text { ¿े } \\
\text { i }\end{array}$ \\
\hline & & $\begin{array}{l}8 \\
8 \\
8 \\
0\end{array}$ & $\begin{array}{l}8 \\
\vdots \\
\dot{y} \\
\vdots\end{array}$ & $\begin{array}{l}8 \\
\vdots \\
\stackrel{1}{=}\end{array}$ & 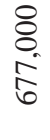 & $\frac{\delta}{\grave{o}}$ & $\begin{array}{l}8 \\
0 \\
\infty \\
\infty \\
\infty\end{array}$ & $\begin{array}{l}8 \\
8 \\
8 \\
\dot{8} \\
\text { r. }\end{array}$ & $\begin{array}{l}8 \\
8 \\
8 \\
8 \\
\text { in } \\
\text { n. }\end{array}$ & $\begin{array}{l}8 \\
8 \\
8 \\
8 \\
0 \\
+\end{array}$ & 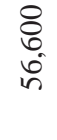 & $\begin{array}{l}8 \\
\infty \\
\infty \\
8\end{array}$ & 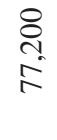 & $\begin{array}{l}8 \\
8 \\
0 \\
0\end{array}$ & $\begin{array}{l}8 \\
8 \\
8 \\
\text { m. }\end{array}$ \\
\hline
\end{tabular}

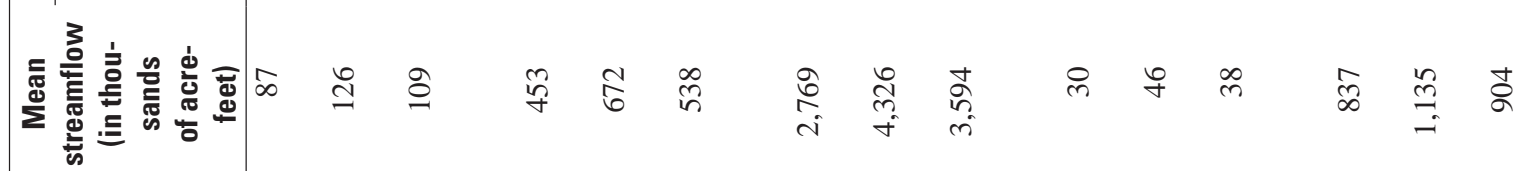

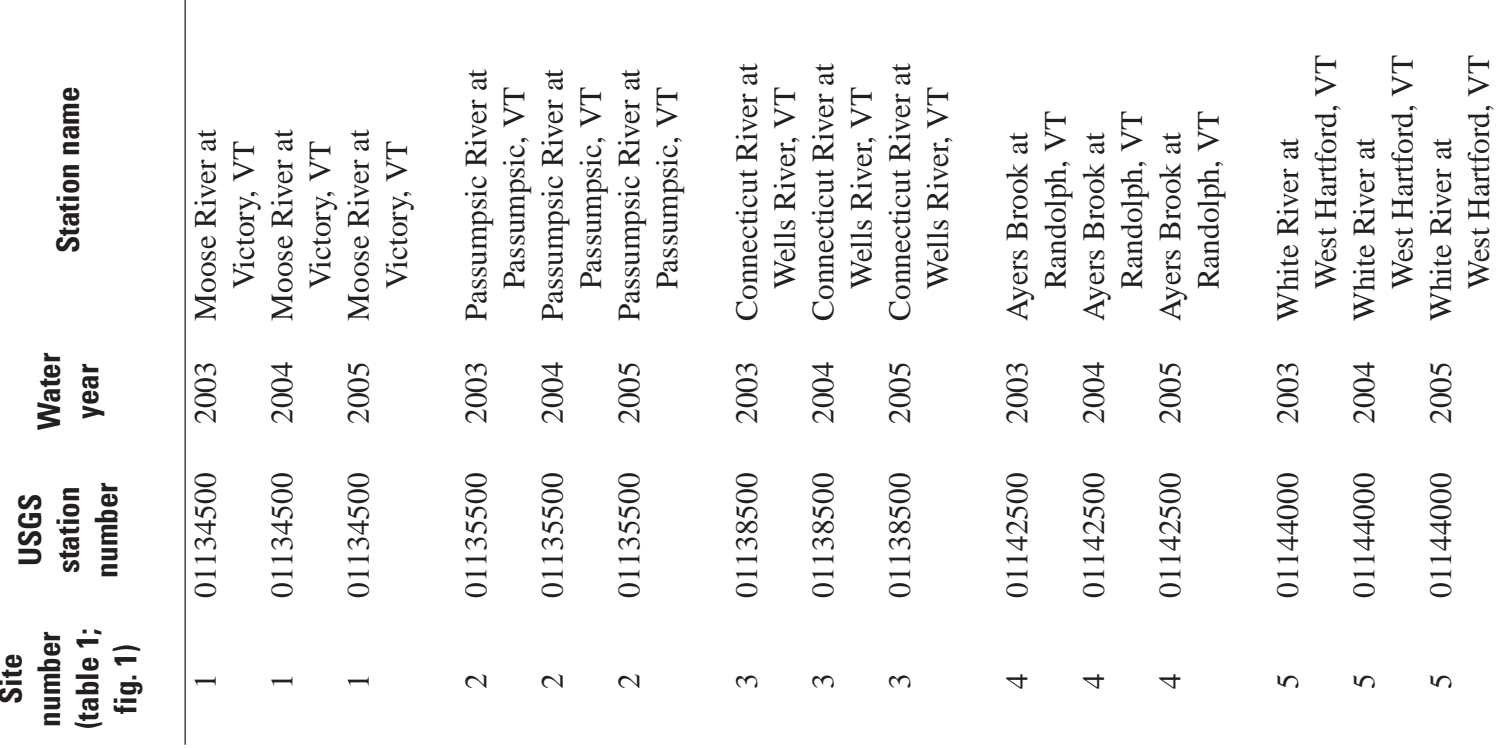




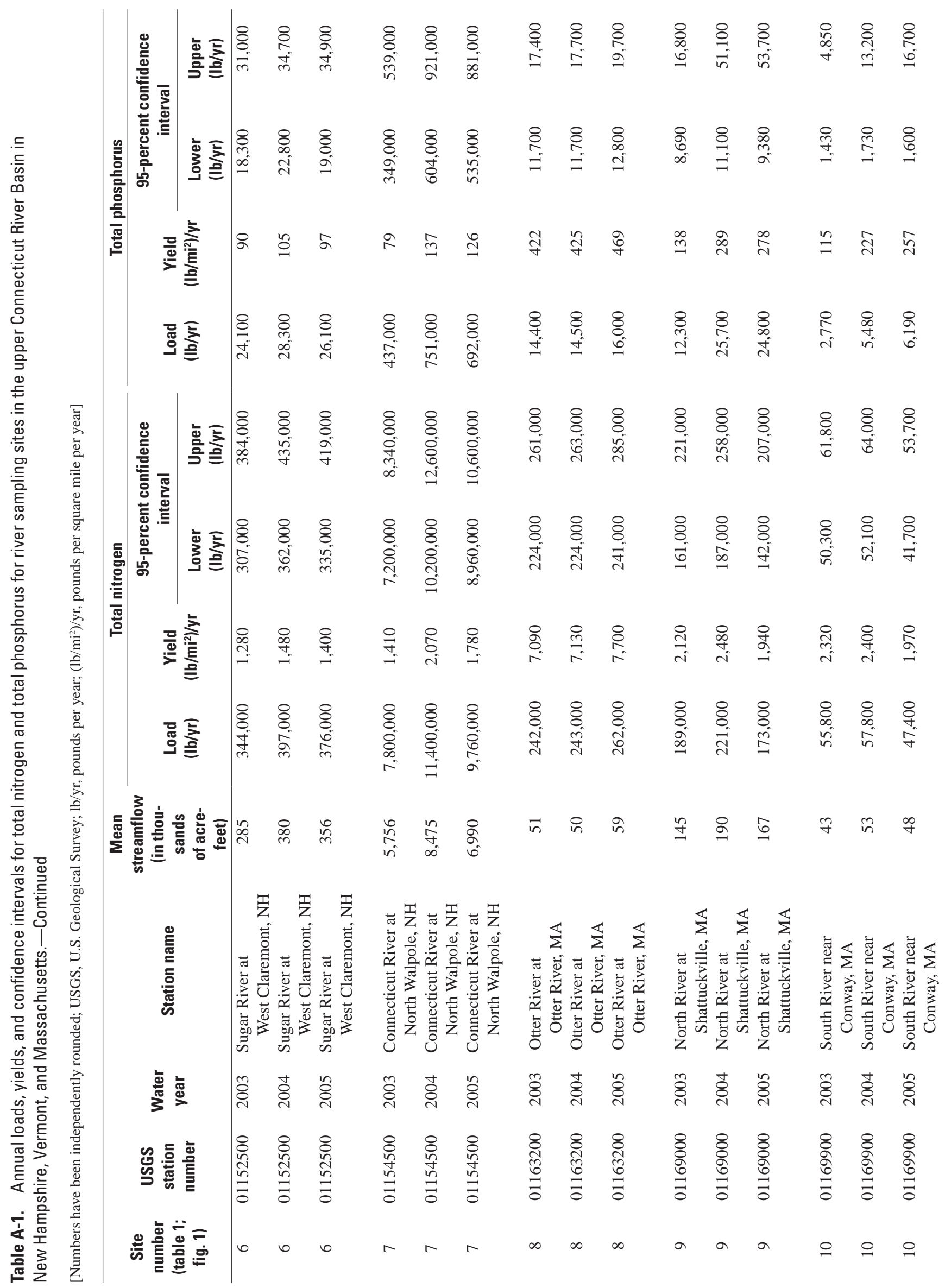


Table A-2. Estimates of seasonal total nitrogen load for river sampling sites in the upper Connecticut River Basin in New Hampshire, Vermont, and Massachusetts.

[Numbers have been independently rounded; USGS, U.S. Geological Survey; lb/season, pounds per season; (lb/mi²)/season, pounds per square mile per season; Winter, December-February; Spring, March-May; Summer, June-August; Fall, September-November]

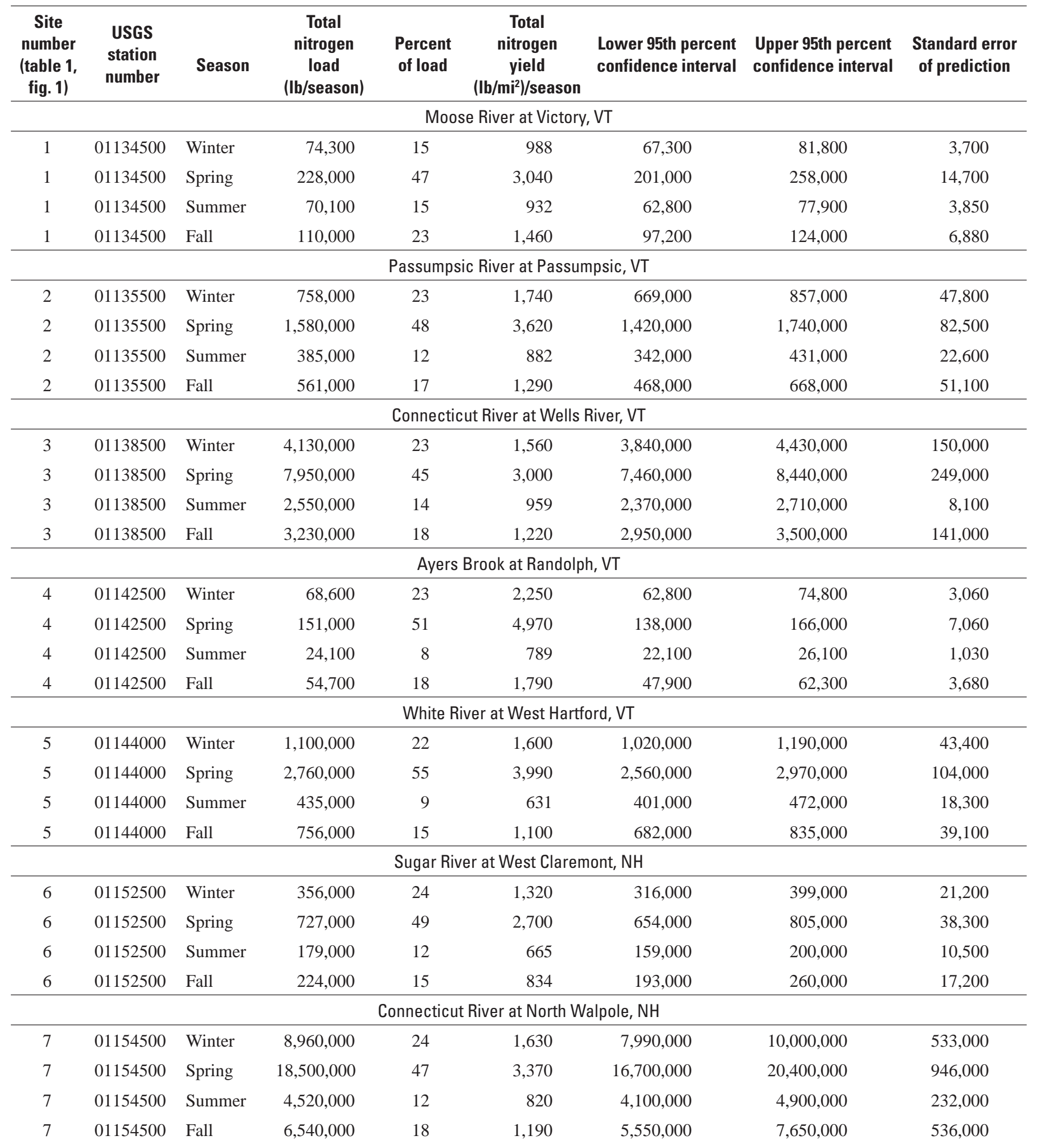


Table A-2. Estimates of seasonal total nitrogen load for river sampling sites in the upper Connecticut River Basin in New Hampshire, Vermont, and Massachusetts._Continued

[Numbers have been independently rounded; USGS, U.S. Geological Survey; lb/season, pounds per season; (lb/mi²)/season, pounds per square mile per season; Winter, December-February; Spring, March-May; Summer, June-August; Fall, September-November]

\begin{tabular}{|c|c|c|c|c|c|c|c|c|}
\hline $\begin{array}{c}\text { Site } \\
\text { number } \\
\text { (table 1, } \\
\text { fig. 1) }\end{array}$ & $\begin{array}{l}\text { USGS } \\
\text { station } \\
\text { number }\end{array}$ & Season & $\begin{array}{c}\text { Total } \\
\text { nitrogen } \\
\text { load } \\
\text { (Ib/season) }\end{array}$ & $\begin{array}{l}\text { Percent } \\
\text { of load }\end{array}$ & $\begin{array}{c}\text { Total } \\
\text { nitrogen } \\
\text { yield } \\
\left(\mathrm{lb} / \mathrm{mi}^{2}\right) / \text { season }\end{array}$ & $\begin{array}{l}\text { Lower 95th percent } \\
\text { confidence interval }\end{array}$ & $\begin{array}{l}\text { Upper 95th percent } \\
\text { confidence interval }\end{array}$ & $\begin{array}{c}\text { Standard error } \\
\text { of prediction }\end{array}$ \\
\hline \multicolumn{9}{|c|}{ Otter River at Otter River, MA } \\
\hline 8 & 01163200 & Winter & 257,000 & 26 & 7,530 & 226,000 & 290,000 & 16,300 \\
\hline 8 & 01163200 & Spring & 293,000 & 29 & 8,600 & 263,000 & 326,000 & 16,200 \\
\hline 8 & 01163200 & Fall & 234,000 & 23 & 6,860 & 202,000 & 269,000 & 17,100 \\
\hline \multicolumn{9}{|c|}{ North River at Shattuckville, MA } \\
\hline 9 & 01169000 & Winter & 169,000 & 22 & 1,900 & 151,000 & 190,000 & 9,890 \\
\hline 9 & 01169000 & Spring & 331,000 & 43 & 3,720 & 267,000 & 404,000 & 35,000 \\
\hline 10 & 01169900 & Winter & 66,700 & 31 & 2,770 & 59,800 & 74,100 & 3,620 \\
\hline 10 & 01169900 & Spring & 84,200 & 39 & 3,490 & 74,500 & 94,700 & 5,160 \\
\hline 10 & 01169900 & Summer & 20,600 & 10 & 856 & 18,500 & 22,900 & 1,120 \\
\hline 10 & 01169900 & Fall & 43,200 & 20 & 1,790 & 37,200 & 49,900 & 3,230 \\
\hline \multicolumn{9}{|c|}{ Green River near Colrain, MA } \\
\hline 11 & 01170100 & Winter & 39,000 & 20 & 943 & 33,600 & 45,100 & 2,930 \\
\hline 11 & 01170100 & Spring & 92,200 & 47 & 2,230 & 68,300 & 122,000 & 13,700 \\
\hline 11 & 01170100 & Summer & 17,000 & 9 & 410 & 14,900 & 19,200 & 1,090 \\
\hline \multicolumn{9}{|c|}{ Mill River at Northhampton, MA } \\
\hline \multicolumn{9}{|c|}{ Connecticut River at Thompsonville, CT } \\
\hline 13 & 01184000 & Winter & $22,900,000$ & 27 & 2,370 & $20,900,000$ & $25,000,000$ & $1,040,000$ \\
\hline 13 & 01184000 & Spring & $35,100,000$ & 41 & 3,640 & $32,200,000$ & $38,300,000$ & $1,580,000$ \\
\hline 13 & 01184000 & Summer & $12,600,000$ & 15 & 1,300 & $11,700,000$ & $13,500,000$ & 448,000 \\
\hline 13 & 01184000 & Fall & $15,600,000$ & 18 & 1,610 & $14,200,000$ & $17,000,000$ & 726,000 \\
\hline
\end{tabular}


Table A-3. Estimates of seasonal total phosphorus load for river sampling sites in the upper Connecticut River Basin in New Hampshire, Vermont, and Massachusetts.

[Numbers have been independently rounded; USGS, U.S. Geological Survey; lb/season, pounds per season; (lb/mi²)/season, pounds per square mile per season; Winter, December-February; Spring, March-May; Summer, June-August; Fall, September-November]

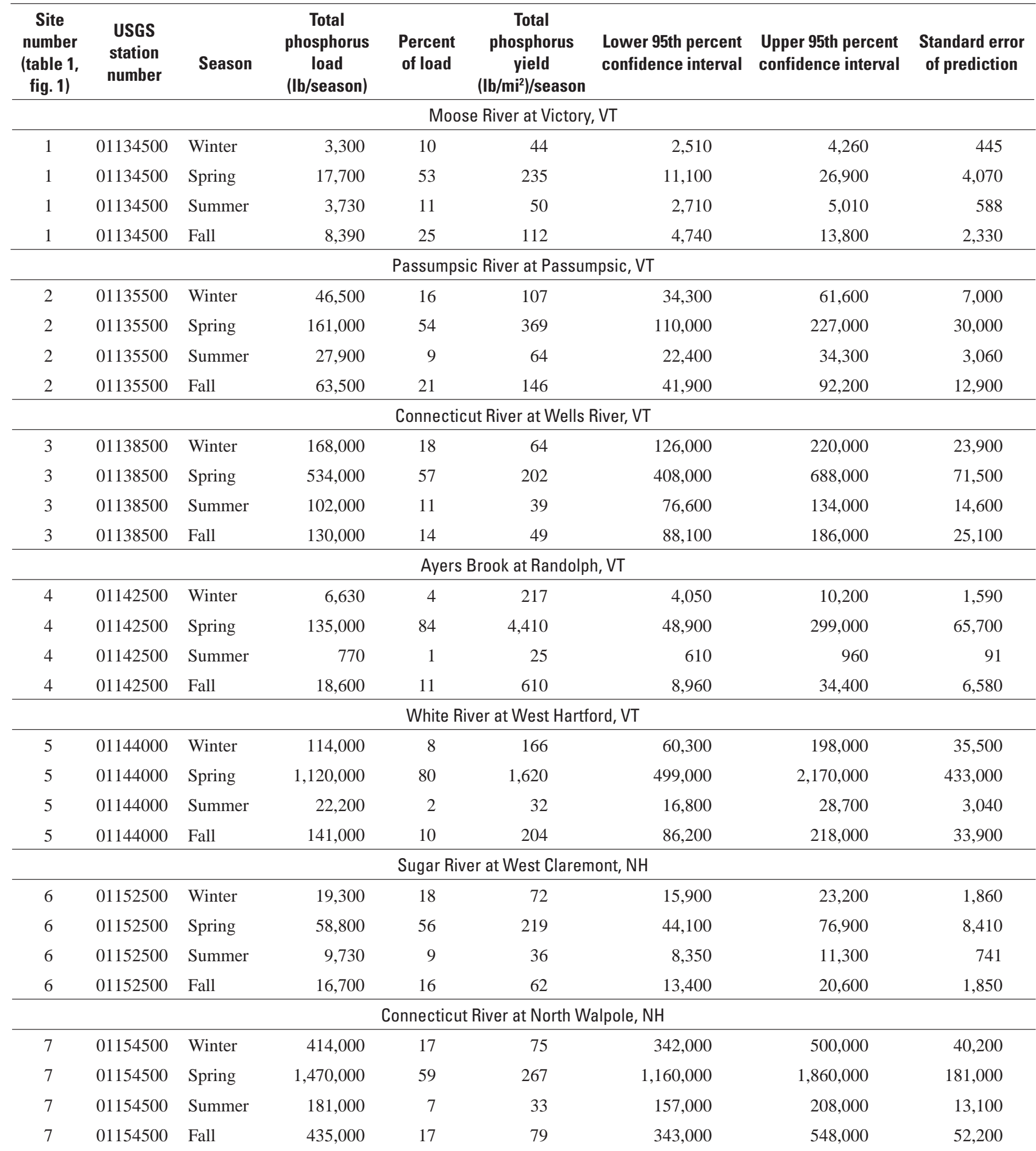


Table A-3. Estimates of seasonal total phosphorus load for river sampling sites in the upper Connecticut River Basin in New Hampshire, Vermont, and Massachusetts.-Continued

[Numbers have been independently rounded; USGS, U.S. Geological Survey; lb/season, pounds per season; (lb/mi²)/season, pounds per square mile per season; Winter, December-February; Spring, March-May; Summer, June-August; Fall, September-November]

\begin{tabular}{|c|c|c|c|c|c|c|c|c|}
\hline $\begin{array}{c}\text { Site } \\
\text { number } \\
\text { (table 1, } \\
\text { fig. 1) }\end{array}$ & $\begin{array}{l}\text { USGS } \\
\text { station } \\
\text { number }\end{array}$ & Season & $\begin{array}{c}\text { Total } \\
\text { phosphorus } \\
\text { load } \\
\text { (Ib/season) }\end{array}$ & $\begin{array}{c}\text { Percent } \\
\text { of load }\end{array}$ & $\begin{array}{c}\text { Total } \\
\text { phosphorus } \\
\text { yield } \\
\left(\mathrm{lb} / \mathrm{mi}^{2}\right) / \text { season }\end{array}$ & $\begin{array}{l}\text { Lower 95th percent } \\
\text { confidence interval }\end{array}$ & $\begin{array}{l}\text { Upper 95th percent } \\
\text { confidence interval }\end{array}$ & $\begin{array}{c}\text { Standard error } \\
\text { of prediction }\end{array}$ \\
\hline \multicolumn{9}{|c|}{ Otter River at Otter River, MA } \\
\hline 8 & 01163200 & Winter & 21,700 & 36 & 636 & 16,000 & 28,800 & 3,280 \\
\hline 8 & 01163200 & Spring & 18,300 & 31 & 536 & 14,000 & 23,400 & 2,410 \\
\hline 8 & 01163200 & Fall & 12,100 & 20 & 356 & 8,360 & 17,100 & 2,230 \\
\hline \multicolumn{9}{|c|}{ North River at Shattuckville, MA } \\
\hline 9 & 01169000 & Winter & 8,340 & 10 & 94 & 5,540 & 12,100 & 1,670 \\
\hline 9 & 01169000 & Spring & 54,100 & 65 & 608 & 20,500 & 117,000 & 25,300 \\
\hline 10 & 01169900 & Winter & 2,460 & 13 & 102 & 1,330 & 4,170 & 734 \\
\hline 10 & 01169900 & Spring & 12,500 & 65 & 518 & 3,270 & 33,500 & 8,100 \\
\hline 10 & 01169900 & Summer & 832 & 4 & 35 & 533 & 1,240 & 183 \\
\hline 10 & 01169900 & Fall & 3,420 & 18 & 142 & 1,220 & 7,670 & 1,690 \\
\hline \multicolumn{9}{|c|}{ Green River near Colrain, MA } \\
\hline 11 & 01170100 & Winter & 1,120 & 12 & 27 & 745 & 1,640 & 230 \\
\hline 11 & 01170100 & Spring & 5,290 & 55 & 128 & 2,380 & 10,200 & 2,040 \\
\hline 11 & 01170100 & Summer & 628 & 7 & 15 & 456 & 840 & 99 \\
\hline \multicolumn{9}{|c|}{ Connecticut River at Thompsonville, CT } \\
\hline 13 & 01184000 & Winter & $1,520,000$ & 21 & 157 & $1,280,000$ & $1,780,000$ & 126,000 \\
\hline 13 & 01184000 & Spring & $3,300,000$ & 46 & 342 & $2,390,000$ & $4,450,000$ & 526,000 \\
\hline 13 & 01184000 & Summer & 944,000 & 13 & 98 & 826,000 & $1,070,000$ & 63,100 \\
\hline 13 & 01184000 & Fall & $1,390,000$ & 19 & 144 & $1,160,000$ & $1,650,000$ & 125,000 \\
\hline
\end{tabular}




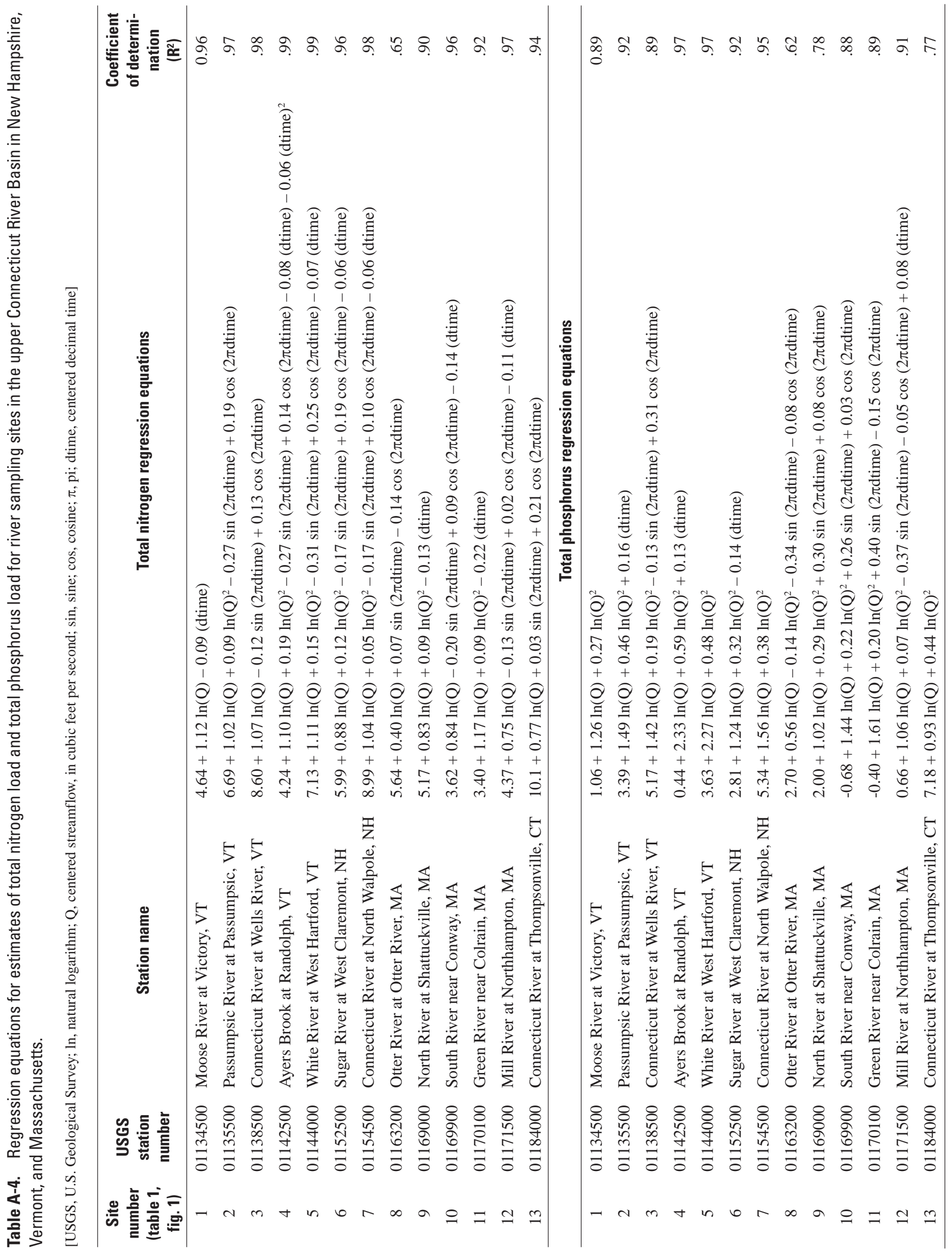


Prepared by Publications Service Center 1

For more information concerning the research in this report, contact: Keith W. Robinson, Director

U.S. Geological Survey

New Hampshire-Vermont Water Science Center

361 Commerce Way

Pembroke, NH 03275

or visit our Web site at:

http://nh.water.usgs.gov 


\section{曾}

3Printed on recycled paper

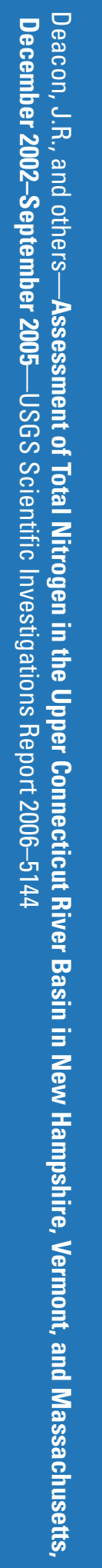

